

\section{DISCLAIMER}

This report was prepared as an account of work sponsored by an agency of the United States Government. Neither the United States Government nor any agency Thereof, nor any of their employees, makes any warranty, express or implied, or assumes any legal liability or responsibility for the accuracy, completeness, or usefulness of any information, apparatus, product, or process disclosed, or represents that its use would not infringe privately owned rights. Reference herein to any specific commercial product, process, or service by trade name, trademark, manufacturer, or otherwise does not necessarily constitute or imply its endorsement, recommendation, or favoring by the United States Government or any agency thereof. The views and opinions of authors expressed herein do not necessarily state or reflect those of the United States Government or any agency thereof. 


\section{DISCLAIMER}

Portions of this document may be illegible in electronic image products. Images are produced from the best available original document. 
The facilities of Argonne National Laboratory are owned by the United States Government. Under the terms of a contract (W-31-109-Eng-38) among the U.S. Department of Energy, Argonne Universities Association and The University of Chicago, the University employs the staff and operates the Laboratory in accordance with policies and programs formulated, approved and reviewed by the Association.

\section{MEMBERS OF ARGONNE UNIVERSITIES ASSOCIATION}

The University of Arizona Carnegie-Mellon University Case Western Reserve University The University of Chicago University of Cincinnati Illinois Institute of Technology University of Illinois Indiana University The University of lowa lowa State University
The University of Kansas Kansas State University

Loyola University of Chicago Marquette University

The University of Michigan

Michigan State University

University of Minnesota

University of Missouri

Northwestern University

University of Notre Dame
The Ohio State University Ohio University

The Pennsylvania State University Purdue University

Saint Louis University

Southern Illinois University

The University of Texas at Austin

Washington University

Wayne State University

The University of Wisconsin-Madison

\section{NOTICE}

This report was prepared as an account of work sponsored by an agency of the United States Government. Neither the United States Government or any agency thereof, nor any of their employees, make any warranty, express or implied, or assume any legal liability or responsibility for the accuracy, completeness, or usefulness of any information, apparatus, product, or process disclosed, or represent that its use would not infringe privately owned rights. Reference herein to any specific commercial product, process, or service by trade name, mark, manufacturer, or otherwise, does not necessarily constitute or imply its endorsement, recommendation, or favoring by the United States Government or any agency thereof. The views and opinions of authors expressed herein do not necessarily state or reflect those of the United States Government or any agency thereof.

This informal report presents preliminary results of ongoing work or work that is more limited in scope and depth than that described in formal reports issued by the Energy and Environmental Systems Division.

Printed in the United States of America. Available from National Technical Information Service, U. S. Department of Commerce, 5285 Port Royal Road, Springfield, Virginia 22161 


\author{
ARGONNE NATIONAL LABORATORY \\ 9700 South Cass Avenue \\ Argonne, Illinois 60439
}

\title{
ANL/EES-TM-121, Vol. 2 \\ CHARACTERIZATION OF ALTERNATIVE ELECTRIC GENERATION TECHNOLOGIES FOR THE SPS COMPARATIVE ASSESSMENT: \\ VOLUME 2 \\ CENTRAL-STATION TECHNOLOGIES
}

$$
\text { prepared by }
$$

TRW Energy Systems Planning Division McLean, Virginia 22102

for

Energy and Environmental Systems Division Argonne National Laboratory under Contract 31-109-38-5459

August 1980

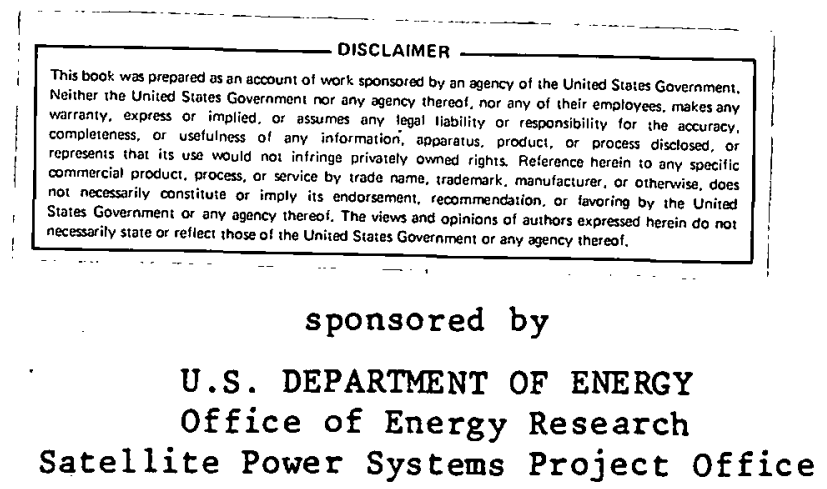


THIS PAGE

\section{WAS INTENTIONALLY LEFT BLANK}




\section{ABSTRACT}

The SPS Concept Development and Evaluation Program includes a comparative assessment. An early first step in the assessment process is the selection and characterization of alternative technologies. This document describes the cost and performance (i.e., technical and environmental) characteristics of six central station energy alternatives:

- Conventional Coal-Fired Powerplant

- Conventional Light Water Reactor (LWR)

- Combined Cycle Powerplant with low-Btu Gasifiers

- Liquid Metal Fast Breeder Reactor. (LMFBR)

- Photovoltaic System without Storage

- Fusion Reactor 


\section{THIS PAGE \\ WAS INTENTIONALLY \\ LEFT BLANK}


1. INTRODUCTION . . . . . . . . . . . . . . . . 1-1

1.0 Background .. . . . . . . . . . . . . . 1-1

1.1 Comparative Assessment and Alternative Characterization . - 1-1

1.2 Basic Assumptions and Data Bases . . . . . . . . . . 1-2

2. CONVENTIONAL COAL FIRED POWERPLANT . . . . . . . . . . . . 2-1

1.0 CONVENTIONAL HIGH SULFUR COAL COMBUSTION WITH

ADVANCED FLUE GAS DESULFURIZATION . . . . . . . . . . . 2-1

2.0 GENERAI PLANT CONFIGURATION . . . . . . . . . . 2-2

3.0. THERMODYNAMIC CYCLE CHARACTERISTICS . . . . . . . 2-5

3.1 Combustion Furnace Boller . . . . . . . . . . 2-5

3.1.1 Turbine Generator Configuration . . . . . . 2-5

3.1.2 Condenser-Heat Rejection System . . . . . . . 2-9

3.1.3 Feedwater Heaters . . . . . . . . . . 2-9

3.1.4 Generator Losses and Auxiliary Electric

Energy Use ............... . 2- 2-9

3.1.5 Fuels Use and Logistics........... . 2-11

4.0 ENVIRONMENTAL CHARACTERISTICS . . . . . . . . . 2-15

4.1 Electrostatic Precipitators . . . . . . . . . . 2-15

4.2 Wellman-Lord Flue Gas Desulfurization . . . . . . . 2-16

4.3 Solid Wastes and Sludges ............. 2-20

4.4 Land and Water Use............. 2-21

5.0 CONGTRUCTION AND OFERATION CHARACTERISTICS . . . . . . 2-23

5.1 Personnel Requirements . . . . . . . . . . . 2-23

5.2 Operating Statistics and Annual Generation . . . . . 2-25

6.0 COST CHARACTERIZATION . . . . . . . . . . . . 2-26

6.1 Direct Capital Costs . . . . . . . . . . . 2-26

6.2 Indirect Capital Costs . . . .......... . 2-31

6.3 Operation and Maintenence Costs ... . . . . . 2-32

3. LIGHT WATER REACTOR WITH IMPROVED FUEL UTILIZATION . . . . . . 3-1

1.0 INTRODUCTION ..................... . . . . I

2.0 GENERAL PLANT CONFIGURATION . . . . . . . . . . . 3-3 
TABLE OF CONTENTS (continued)

Page

3.0 THERMODYNAMIC CYCLE CHARACTERISTICS . . . . . . . . . 3-6

3.1 Reactor Core and Vessel ... . . . . . . . 3-6

3.2 Reactor Plant Equipment . . . . . . . . . . . 3-8

3.3 Turbine Generator Configuration . . . . . . . . . 3-8

3.4 Condenser-Heat Rejection System . . . . . . . . . . 3-9

3.5 Feedwater Heaters . . . . . . . . . . . . 3-10

3.6 Generator Losses and Auxiliary Electric Energy Use . . 3-1U

3.7 Fuel Use and Logistics... . . . . . . . . 3-12

4.0 ENVIROMMENTAL CHARACTERISTICS ............ 3-13

4.1 Solid Waste . . . . . . . . . . . . . . 3-13

4.2 Land and Water Use .. . . . . . . . . . . . 3-18

5.0 CONSTRUCTION AND OPERATION CHARACTERISTICS . . . . . . 3-20

5.1 Operating Statistics and Annual Generation . . . . . 3-22

6.0 COST CHARACTERIZATION . . . . . . . . . . . . . 3-24

6.1 Direct Capital Costs . . . . . . . . . . . . 3-24

0.2 Iullilecit Capital Custs... . . . . . . . . . . 326

6.3 Operation and Maintenance Costs......... . 3-27

7.0 NUCLEAR FUEL CYCLE . . . . . . . . . . . . . . 30

7.1 Air Emissions ............. 3-30

7.1.1 Mining .............. . . 3-30

7.1 .2 Milling ................ 3-32

7.1.3 Uranium Hexafluoride Production . . . . . . . 3-32

7.1.4 Uranium Enr1chment . . . . . . . . . . 3-33

7.1 .5 Fuel Fabrication ............. 3-34

7.1 .6 Power Plant.............. . . 3-34

7.1.7 Waste Management (AFR Storage and Final

Disposal)............. . 3-35

7.1.8 Iransportation ............... 3-39

7.2 Liquid Effluents . . . . . . . . . . . 3-35

7.2.1 Mining ............... . . 3-35

7.2 .2 Milling ................. 3-35

7.2.3 Uranium Hexafluoride Production ...... . 3-36

7.2.4 Uranium Enrichment ............ 3-36

7.2.5 Fuel Fabricátion ............. 3-37

7.2.6 Radioactive Waste Management ....... 3-37

7.2.7 Transportation ............ 3-37 
TABLE OF CONTENTS (continued)

Page

7.3 Solid Waste. .............. 3-38

7.3.1 Mining ............... 3-38

7.3.2 Milling ................. . . 3-38

7.3.3 Uranium Hexafluoride Production . . . . . . 3-38

7.3.4 Uranium Enrichment . . . . . . . . . . 3-38

7.3.5 Fuel Fabrication ............. 3-38

7.3.6 Radioactive Waste Management. . . . . . 3-38

7.3.7 Transportation ........... 3-38

7.4. Waste Heat . . . . . . . . . . . . . 3-38

7.4.1 Mining ............... . . 3-38

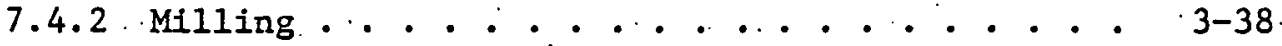

7.4.3 Uranium Hexafluoride Production . . . . . . 3-39

7.4.4 Uranium Enrichment . . . . . . . . . 3-39

7.4.5 Fuel Fabrication ............. 3-39

7.4.6 Radioactive Waste Management . . . . . . 3-39

7.4.7 Transportation ... . . . . . . . 3-39

7.5 Disruption of Land Areas . . . . . . . . . 3-39

7.5.1 Mining ................ . 3-39

7.5 .2 Milling................. 3-39

7.5.3 Uranium Hexafluoride Production . . . . . . 3-40

7.5 .4 Uranium Enrichment . . . . . . . . . . 3-40

7.5.5 Fuel Fabrication ............. 3-40

7.5.6 Power Plant ............... . 3-40

7.5.7 Radioactive Waste Management . . . . . . . 3-40

7.5 .8 Transportation ............ 3-40

7.6 Manpower Requiremento ... . . . . . . 3-40

4. COMBINED CYCLE WITH INTEGRAL LOW BtU GASIFICATION . . . . . . . 4-1

1.0 INTRODUCTION . . . . . . . . . . . . . . 4-1

2.0 GENERAL PLANT CONFIGURATION .............. . . 4-3

2.1 Coal Handling and Storage ............ 4-3

2.2 T.Rtu Filel Plant . . . : : . : . : : . . . . . . . . 1 1-3

2.3 Power Generation Area ... . . . . . . . . . 4-5

2.4 Solid Wastes Handling . . . . . . . . . . . . 4-5

2.5 Cooling Towers ................ 4-5

2.6 Ponds .................... 4-5

2.7 Logistics and Operation ........... 4-5

3.0 THERMODYNAMIC CYCLE CHARACTERISTICS .......... 4-7 
3.1 Advanced Technologies . . . . . . . . . . 4-9

3.2 LBtu Fuel Plant . . . . . . . . . . . . . . . 4-14

3.3 Gas Cleanup System . . . . . . . . . . . . 4-15

3.4 Gas Turbine System . . . . . . . . . . . . 4 4-15

3.5 HRSG-Steam Turbine System .. . . . . . . . . 4-16

3.6 Feedwater System ... . . . . . . . . . . 4-17

3.7 Steam Extractions .. . . ........... . 4-17

3.8 Generation . . . . . . . . . . . . . . 4-18

3.9 Fuels Use and Logistics . . . . . . . . . . . 4-18

4.0 ENVIRONMENTAL CHARACTERISTICS . . . . . . . . . . . . 4-19

4.1 Overall Env1ronmencal Impact , . , . . . . , . . 4-19

4.2 Fuel Gas Cleanup System - Sulfur . . .. . . . . . . 4-19

4.3 Control of $\mathrm{NO}_{\mathrm{x}}$.................. . . 4-22

4.4 Cleanup of Process Water Systems .......... 4-22

4.5 Liquid Waste .. . . . . . . . . . . . 4-23

4.6 Solid Waste .. . . . . . . . . . . . . 4-23

4.7 Specific Data on Residuals . . . . . . . . . . 4-23

4.7.1 Air Emissions ... . . . . . . . . 4-23

4.7.2 Liquid Effluents .............. 4-23

4.7.3 Solid Wastes .............. 4-24

4.7.4 Land Use ................ . 4-24

4.7.5 Water Consumption.......... 4-..24

5.0 CONSTRUCTION AND OPERATION CHARACTERISTICS . . . . . . 4-26

5.1 Personnel Requirements . . . . . . . . . . . 4-26

5.2 Operating Statistics and Annual Generation... . . 4-26

5.3 Gasifier Requirements . . . . . . . . . . 4-28

6.0 COST CHARACTERIZATION (CG/CC) . . . . . . . . 4-30

6.1 Direct Capital Costs................ 4-30

6.2 Indirect Capital Costs . . . . . . . . . . . . 4-35

6.3 Operation and Maintenance Costs . . . . . . . 4-36

7.0 THE COAL FUEL CYCLE DESCRIPTION . . . . . . . . . . 4-40

7.1 Air Emissions . . . . . . . . . . . . 4-41

7.1.1 Mining .................. 4-41

7.1 .2 Preparation ............... 4-41

7.1.3 Transportation ............ 4-44 
TABLE OF CONTENTS (continued)

Page

7.2 Liquid Effluents.............. 4-... 45

7.2.1 Mining ............... . 4-45

7.2.2 Preparation .............. 44-46

7.2.3 Transportation ............. . 4-47

7.3 Solid Waste ............... 44-47

7.3.1 Mining ................. 4-47

7.3.2 Transportation .......... 4-...47

7.3.3 Preparation ............. . 4-47

7.4 Disruption of Land Areas . . . . . . . . . . 4-48

7.4.1 Mining (Surface) and Preparation ...... . 4-48

7.4.2 Mining (Underground) and Preparation . . . . 4-48

7.4.3 Transportation ............ 4-49

7.5 Manpower Requirements ............ 4-49

5. LIQUID METAL FAST BREEDER REACTOR (LMFBR) . . . . . . . . . 5-1

1.0 INTRODUCTION ....................... . . . . . .

2.0 GENERAL PLANT CONFIGURATION . . . . . . . . . . . 5-4

3.0 THERMODYNAMIC CYCLE CHARACTERISTICS . . . . . . . . 5-6

3.1 Reactor Heat-Generation System .......... 5-9

3.2 Auxiliary Systems ............. . 5-10

3.3 Instrumentation and Control ........... 5-12

3.4 Reactor Containment ............... 5-12

3.5. Turbine Generator Configuration . . . . . . . . . . 5-12

3.6 Condenser-Heat Rejection System . . . . . . . . 5-13

3.7 Feedwater Heaters .. . . . . . . . . . . . 5-13

3.8 Generator Losses and Auxiliary Electric Energy Use . . 5-15

3.9 Fuel Use and Logistics ... . . . . . . . . 5-15

4.0 ENVIRONMENTAL CHARACTERISTICS . . . . . . . . . 5-18

4.1 Air Emissions . . . . . . , . . , . , . . 5-18

4.2 Liquid Effluents................ 5-19

4.3 Solid Wastes... . . . . . . . . . . . . 5-21

4.4. Reject Waste Heat ............. . 5-21

4.5 Land and Water Use.............. 5-22

5.0 CONSTRUCTION AND OPERATION CHARACTERISTICS . . . . . . 5-24

5.1 Operating Statistics and Annual Generation . . . . . 5-27 
TABLE OF CONTENTS (continued)

Page

6.0 COST CHARACTERIZATION (LMFBR) . . . . . . . . . . 5-29

6.1 Direct Capital Costs . . . . . . . . . . . . 5-29

6.1 Indirect Capital Costs . . . . . . . . . . . . . 5-32

6.3 Operation and Maintenance Costs . . . . . . . . 5-33

7.0 LMFBR FUEL CYCLE . . . . . . . . . . . . . 5-36

7.1 Air Emission . . . . . . . . . . . . . 5-38

7.2 Liquid Effluents ............... 5-39

7.3 Solid Wastes.................. 5-39

7.4 Waste Heat... . . . . . . . . . . . . . . 5-39

7.5 Resnurce Requirements , . . . . . . . . . . . . 5m39

6. CENTRAL STATION PHOTOVOLTAIC ................ . 6-1

1.0 INTRODUCTION .................... 6-1

2.0 GENERAI PLANT DESCRIPTION .............. 6-2

3.0 CONVERSION CYCLE DESCRIPTION . . . . . . . . . 6-4

3.125 MW Module . .. . . . . . . . . . . 6-4

3.2 Central Plant . . . . . . . . . . . . . . 6-4

3.3 Electrical System Description . . . . . . . 6-7

१.0 ENVIRONMENTAL IMPACTS OR REEIDUALS

4.1 Air . . . . . . . . . . . . . . . . 6-9

4.2 Water ................. . 6-9

4.3 Solid Wastes . . . . . . . . . . . . . . 6-9

4.4 Thermal Emissions . . . . . . . . . . . . . . 6-9

4.5 Reflected Inoolation . . . . . . . . . . . . 6-9

4.6 Land Use................. . . 6-10

5.0 CONSTRUCTION AND OPERATING CHARACTERISTICS . . . . . . 6-1I

5.1 Construction . . . . . . . . . . . . . , 6-11

5.2 Operations and Maintenance... . . . . . . 6-11

5.2.1 Maintenance of Arrays . . . . . . . . . 6-12

5.2.2 Balance-of-Plant Maintenance ...... . 6-13

6.0 COST CHARACTERIZATION (TERRESTRIAL PHOTOVOLTAIC) . . . . . 6-14

6.1 Direct Capital Costs . . . . . . . . . . 6-14

6.2 Indirect Capital Costs . . . . . . . . . . . 6-15

6.3 Operating and Maintenance Expenses . . . . . . . 6-17 
TABLE OF CONTENTS (continued)

Page

7. MAGNETIC CONFINEMENT FUSION . . . . . . . . . . . . . . 7-1

1.0 INTRODUCTION ................... . . . . . .

2.0 GENERAL PLANT CONFIGURATION ............. 7-3

3.0 THERMODYNAMIC CYCLE CHARACTERISTICS . . . . . . . . . 7-6

3.1 Fusion Reactor .................. . 7-7

3.2 The Reactor Blanket System .. . . . . . . . . . 7-9

3.3 Thermodynamic Parameters . . . . . . . . . . . 7-11

3.4 Fuel Use . . . . . . . . . . . . . . 7-14

4.0 ENVIRONMENTAL CHARACTERISTICS ........... 7-15

4.1 Tritium . . . . . . . . . . . . . . 7-15

4.2 Blanket (Solid Radioactivity) Waste......... 7-18

4.3 Land and Water Use . . . . . . . . . . . 7-18

5.0 CONSTRUCTION AND OPERATING CHARACTERISTICS . . . . . . 7-22

5.1 Construction Time .. . . . . . . . . . . . . 7-22

5.2 Construction Personnel Requirements . . . . . . . . 7-22

5.3 Resource Requirements .............. . 7-22

5.4 Operating Personnel Requirements . . . . . . . . 7-24

5.5 Plant Availability ............. 7-25

6.0 COST CHARACTERIZATION (FUSION) . . . . . . . . . . 7-26

6.1 Direct Capital Costs................ 7-26

6.2 Indirect Capital Costs . . . . . . . . . . . 7-28

6.3 Operatione and Maintenance Costo......... 7-29

A. APPENDIX - COST ESTIMATING RELATIONSHIPS FOR REFERENCE COAL GASIFICATION COMBINED CYCLE SYSTEM . . . . . . . A A-1 
2-1. Plot Plan - 1250 MWE Reference High-Sulfur Coal System . . . 2-3

2-2. Simplified Schematic of High-Sulfur Coal Generation

Facility . . . . . . . . . . . . . . . . 2-7

2-3. Wellman-Lord Process . . . . . . . . . . . . . . . 2-17

3-1. Plot Plan 1250 MWe LWR Facility . . . . . . . . . . . 3-4

3-2. Light Water Reactor Facility Heat Balance. . . . . . . . . 3-11

4-1. 1250 MWe Reference Coal Gasificiation Power Facility . . . . . 4-4

4-2. Simplified Schematic Diagram of Open Cycle Gas Turbine

Combined - Air Cooled - LBtu Gasifier . . : . . . . . . . . 4-8

4-3. Environmental Residuals Summary for 1250 MWe Low Btu

Gasifier Combined Cycle Plant ............. 4-20

4-4. Coal Mining Cycle Summary .. . . . . . . . . . . 4-40

5-1. The Plot Plan for the LMFBR Facility . . . . . . . . . 5-5

5-2. Simplified Diagram of Heat Transfer System . . . . . . . . 5-6

5-3. Pool and Loop-type Primary Coolant System Configuration... . 5-8

5-4. Simplified Cycle Schematic - 1250 MWe - Reference

IMFBR Facility .................. 5-14

5-5. Nuclear-fuel Cycle for LMFBR . . . . . . . . . . . 5-36

5-6. Material Flowsheet for LMFBR . . . . . . . . . . . 5-37

6-1. Solar Facility Plot Plan . . . . . . . . . . . . 6-3

6-2. Solar Panel Arrangement . . . . . . . . . . . . 6-6

7-1. Comparison of Power Cycle for NUWMAK to a Conventional

Tokamak Reactor . . . . . . . . . . . . . 7-2

7-2. Overall Plant Layout for Two 660 MWe NUWMAR . . . . . . . 7-4

7-3. NUWMAK Reactor Building Layout . . . . . . . . . . . 7-5

7-4. Deuterium-Tritium (D-T) Fusion Reaction . . . . . . . . 7-6

7-5. Power Flow Diagram for NUWMAK ............. . 7-7 


\section{LIST OF FIGURES (continued)}

Page

7-6. Cross-Sectional View of NUWMAK . . . . . . . . . . 7-8

7-7. Cross-Sectional View of Blanket . . . . . . . . . . . 7-11

7-8. Schematic Showing Components in NUWMAK Load-Leveling System . 7-12

7-9. Tritium Effluent System Design . . . . . . . . . . 7-16

7-10. Radioactivity of the NUWMAK . . . . . . . . . . . 7-19

7-11. Afterheat in NUWMAK . . . . . . . . . . . . . 7-20

7-12. Biological Hazard Potential for NUWMAK . . . . . . . . . 7-21 


\section{LIST OF TABLES}

Page

2-1. Typical Eastern High Sulfur Coal Characteristics . . . . . 2-6

2-2. Auxiliary Electric Power Requirement for Reference 1250 MWe High-sulfur Coal Facility . . . . . . . . . . . . 2-10

2-3. Key Plant Parameters - 1250 MWe High-sulfur Coal Plant • . . 2-13

2-4. Air Residuals - 1250 MWe Reference High-sulfur Coal Gerieraliul . . . . . . . . . . . . . . . . . . . . . 2-19

2-5. Solld and Sludge Wastes - $1250 \mathrm{MWe}$ Reference High-sulfur Coal Generation - 70\% Capacity Factor . . . . . . . . . . 2-20

2-6. Water Use - 1230 WWe H1gh-sulfur Cual Generatiun . . . . . . 2-21

2-7. Typical Wastewater Effluents - 1250 MWe Coal Combustion Facility at $70 \%$ Capacity Factor . . . . . . . . . . . . 2-22

2-8. Direct Labor Summary for Construction Craft Labor for Reference 1250 MWe Coal Facility . . . . . . . . . . . 2-23

2-9. Direct Labor Summary for Construction and Operation of Reference $1250 \mathrm{MWe}$ Coal Facility . . . . . . . . . . . . . 2-24

2-10. Estimated Direct Capital Costs for $1250 \mathrm{MWe}$ Coal Combustion Reference System (January I, 1978 Dollars) . . . . 2-30

2-11. Estimated Indirect Capical Coscs for $1250 \mathrm{MWe}$ Coal Combustion Reference System (January 1, 1978 Dollars) . . . . 2-31

2-12. Annual Operation and Maintenance Costs for $1250 \mathrm{MWe}$ Reference High-sulfur Coal Facility at 70\% Capacity Factor : 2-34

3-1. Key Harameters Nuclear Steam Supply Syscem 1250 MWe Pressurlzed Water Reactor Plant . . . . . . . . . . . . . 3-7

3-2. Key Plant Parameters, Steam and Power Conversion System 1250 MWe Pressurized Water Reactor Plant . . . . . . . . . . 3-9

3-3. Auxiliary Power Requirements . . . . . . . . . . . . . . 3-10

3-4. Expected Annual Average Release of Airborne Radionuclides . . 3-14

3-5. Expected: Annual Average Releases of Radionuclides in Liquid Effluents . . . . . . . . . . . . . . . 3-16

3-6. Annual Weight, Volume, and Activity of Radwaste Shipped . . . 3-17

3-7. Water Use in a 1250 MWe Light Water Reactor . . . . . . . . 3-18 
LIST OF TABLES (continued)

Page

3-8. Waste Water Effluents - 1250 MWe LWR Facility at

$70 \%$ Capacity Factor ................. 3-19

3-9. Direct Craft Labor Summary - 1250 LMFBR Plant -

Cost Basis July 1976 . . . . . . . . . . . . . . . . 3-21

3-10. Staff Requirements for LWR Plant . . . . . . . . . . 3-23

3-1i. Estimated Direct Capital Costs for 1250 MWe Light Water

Reactor Reference System (January 1, 1978 Dollars) . . . . 3-26

3-12. Estimated Indirect Capital Costs for 1250 MWe Light Water

Reactor Reference System (January 1, 1978 Dollars) . . . . . 3-27

3-13. Annual Operation and Maintenance Costs - 1250 MWe

Reference Nuclear Light Water Reactor Facility at $70 \%$

Capactly Factor . . . . . . . . . . . . . . . . 3-29

4-1. Typical Eastern Bituminous High-sulfur Coal

Characteristics... . . . . . . . . . . . . 4-7

4-2. System Parameters Open Cycle Gas Turbine Combined -

Air Cooled . . . . . . . . . . . . . . . 4-11

4-3. Summary of Design Parameters - Open Cycle Gas Turbine

Combinèd Cycle with Low Btu Gasifier .. . . . . . . . . . 4-12

4-4. Low Btu Fuel Gas Composition . . . . . . . . . . . 4-16

4-5. Summary of Flow of Major Residual Materials for
Environmental Control System . . . . . . . . . . . 4-25

4-6. Direct Labor Summary for Operation of Reference $1250 \mathrm{MW}$

Coal Gasification Facility/Combined Cycle (2 Units) . . . . 4-27

4-7. Summary of Gasifler Avallability Analysis . . . . . . . . . 4-29

4-8. Estimated Direct Capital Costs for Two Unit $1250 \mathrm{MWe}$

Reference Coal Gasification Combined Cycle Facility

(January 1, 1978 Dollars) . . . . . . . . . 4-34

4-9. Estlmaced Indirect Capital Costs for 1250 MWe Coal

Gasification Combined Cycle Reference System

(January 1, 1978 Dollars) . . . . . . . . . . . . 4-36

4-10. Annual Operation and Maintenance Costs - 1250 MWe Reference

Coal Gasification Combined Cycle Facility at $70 \%$ Capacity

Factor 


\section{LIST OF TABLES (Continued)}

Page

4-11. Coal Mining Air Emissions Factors for Surface Mining . . . 4-42

4-12. Coal Preparation Air Emission Factors........... . 4-43

4-13. Coal Transportation Air Emission Factors (Tons/Day) . . . . 4-44

4-14. Coal Mining Wastewater Effluents (Tons/Day) . . . . . . . 4-45

4-15. Coal Cleaning Wastewater Effluents Refuse Pile
Run-off (Tons/Day) . . . . . . . . . . . . 4-46

4-16. Mining Solid Waste Effluents .......... . . . . 4-47

4-17. Loal preparatión solid wàste Etfiluents . . . . . . . . 4-48

5-1. Key Plant Parameters for LMFBR Primary System . . . . . . . 5-11

5-2. LMFBR Fuel Design Parameters . . . . . . . . . . . 5-16

5-3. Postulated Radionuclide Release - 1250 MWe LMFBR Power
Plant at $70 \%$ Capacity Factor . . . . . . . . . . . . - .

5-4. LMFBR Wastewater Effluents at Nominal (1250 MWe) Operation . 5-20

5-5. Water Use - 1250 MWe IMFBR . . . . . . . . . . . . 5-23

5-6. Direct Craft Labor Summary - 1250 LMFBR Plant . . . . . . . 5-25

5-7. Staff Requirements for LWR Plant ............ 5-26

5-8. Estimated Direct Capital Costs for 1250 MWe Liquid Metal

Fast Breeder Reactor Reference System (January I, 1978

Dollars) .. . . . . . . . . . . . .. . 5-31

5-9. Estimated Indirect Capital Costs for 1250. MWe Liquid

Metal Fast Breeder Reactor Reference System. (January 1,

1978 Dollars) .................. 5-32

5-10. Annual Uperation and Maintenance Costs - 1250 MWe

Reference Liquid Metal Fast Breeder Reactor Facility

at $70 \%$ Capacity Factor . . . . . . . . . . . 5-34

6-1. 25 MW Solar Photovoltaic Central Plant Array Parameters . . . 6-5

6-2. Estimated Direct Base Construction Costs - 200 MWe Solar

Photovoltaic Central Power Station (in January I, 1978

Dollars) ..................... 6-16 
LIST OF TABLES (continued)

Page

6-3. Estimated Indirect Capital Costs for 200. MWe Solar

Photovoltaic Central Power Station (in January I, 1978

Dollars) .................. 6-17

6-4. Estimated Annual Operating and Maintenance Costs - 200 MWe

Reference Solar Photovoltaic Central Power Station (in

January 1, 1978 Dollars) . . . . . . . . . . . 6-20

7-1. Problems, Causes and Possible Solutions for a

Tokamak Blanket . . . . . . . . . . . . . . . 7-10

7-2. Sumary of Thermodynamic Parameters for

One NUWMAK Reactor .................. 7-13

7-3. Tritium Inventory Under a DT Pellet Fueling Scheme . . . . 7-14

7-4. Materlals Requirements and Avallability in a 300 GWe

Economy of NUWMAK Type Reactors . . . . . . . . . . . 7-23

7-5. Estimated Direct Capital Costs for 1320 MWe Fusion

Reference System (January 1, 1978 Dollars) . . . . . . . 7-28

7-6. Estimated Indirect Capital Costs for 1320 MWe Fusion

Reference System (January 1, 1978 Dollars) . . . . . . . 7-29

7-7. Annual Operation and Maintenance Costs - $1320 \mathrm{MWe}$

Reference, Fusion Reactor System at 70\% Capacity Factor . . . 7-30

A-1. Equipment and Materials List-Structures and Improvements -

Account 21 (ECAS Acct. 1.0) 1975 Dollars . . . . . . . A-4

A-2. Equipment and Materials List - Coal Handling Gasification

and Gas Cleanup - Account 22 (ECAS Acct. 2.0) - 1975 Dollars. A-5

A-3. Equipment and Materials List - Prime (Gas Turbine) Cycle

Equipment - Account 23 (ECAS Acct. 3.0) - 1975 Dollars . . . A-7 


\section{SECTION 1. INTRODUCTION}




\section{INTRODUCTION}

\subsection{BACKGROUND}

The SPS Concept Development and Evaluation Program (CDEP)* was estabIished by the Department of Energy and the National Aeronautics and Space Administration to generate information from which a rational decision cound be made regarding the direction of the Satellite Power System (SPS) program after fiscal 1980. The comparative assessment program is one of four functional areas within the joint DOE/NASA-CDEP. The other CDEP functional areas are:

- Systems Definition: SPS reference ${ }^{* * *}$ and alternative concept designs

- Environmental Assessment: evaluation of environmental impacts (e.g., health \& safety, ecological) of the SPS operation

- Societal Assessment: evaluation of international issues, institutional issues, resource issues and public outreach

The results of these three activities are inputs to the comparative assessment process, as well as to program assessments.

\subsection{COMPARATIVE ASSESSMENT AND ALTERNATIVE CHARACTERIZATION}

The objective of the comparative assessment is to develop an initial understanding of the SPS with respect to a limited set of energy alternatives. A comparative methodology report describes the multi-step process in the comparative assessment. The first step is the selection and characterization of alternative energy systems. Terrestrial alternatives are selected, and their cost, performance, and environmental and social attributes are specified for use in the comparison with the SPS in the post-2000 era. Data on alternative technologies were sought from previous research and from other comparisons.

The objective of this report is to provide a traceable characterization of the eost and perforwatice (i.e., environmental and technical) of competing

*Satellite Power System (SPS) Concept Development and Evaluation Program Plan, DOE/ET-0034 (February 1978).

$* *$ U.S. Department of Energy and NASA, SPS CDEP Reference System Report, DOE/ ER-0023 (October 1978). 
technologies. The following central station technologies have been selected for comparison:

- Conventional Coal-Fired Powerplant

- Conventional Light Water Reactor (LWR)

- Combined Cycle Powerplant with low-Btu Gasifiers

- Liquid Metal Fast Breeder Reactor (LMFBR)

- Photovoltaic system without storage

- Fusion Reactor

Volume 3 - of the tcchnology characterization repnrt describes a rooftop decentralized photovoltaic option that was also compared to SPS.

\subsection{BASIC ASSUMPTIONS AND DATA BASES}

The technologies listed in Section 1.2 either exist currently or have proven principles of operation with one exception: the fusion reactor. The fusion reactor will probably not be ready for commercial operation by the year 2000. Best estimates call for a fusion reactor ready by the year 2020 or later depending on the pace and success of current R\&D programs. However, for comparative purposes, the fusion reactor has been included in this report.

The primary data base used for this report was "Satellite Power System and Alternative Technology Characterization," UE\&C-ANL-790831, prepared by United Engineers and Constructors. In this document, UE\&C prepared characterizations and prepared estimates of the costs of the various technologies under consideration. The units characterized by UE\&C were standard sizes and represented the technology of the mid-1970's. However, for the purposes of this report, these technologies were scaled to a common size ( $1250 \mathrm{MWe}$ ) and extrapolated to the year 2000. Scaling of the units, a fairly routine practice, is discussed in the individual sections. Extrapolation of the units to the year 2000 is more difficult.

- The primary advances in nuclear technology will be related to safety equipment and systems, rather than performance enhancement advances.

- The LMFRR and fusion reactors represent new technologies and nothing beyond the first generation configurations is assumed. 
- Continued tightening of EPA emission and effluent standards will bring advances in pollution control equipment. A Wellman-Lord Flue Gas Desulfurization system is assumed for the coal-fired powerplant. Enhanced air emissions control equipment is also assumed for the combined cycle unit. Magnetohydrodynamics and large-scale fluidized bed combustion are not assumed to be ready by the year 2000 .

- Photovoltaic technology will produce ribbonlike cells, thus allowing closer packing factors than would be achievable by the round cells. In addition, the price of PV cells is assumed to continue its downward trend.

- Design and construction codes, standards, regulations and guidelines applicable around 1975-1976 represent those in effect for the powerplant in 2000 escalated at the rate of inflation plus $10 \%$.

Other assumptions made for the technology characterizations are addressed in the individual sections.

All of the characterized power stations are located on a suitable site near "Middletown, USA." The site has a major freshwater river flowing next to the plant site to provide makeup and, in essence; is ideal for a powerplant. None of the technology characterizations presented in this report has been optimized. Rather, they describe in general terms what a powerplant would look like if that technology were developed. Despite this lack of an optimized design, the cost estimates are considered valid for comparative purposes. The estimates are believed to lie within the limits of estimating techniques for periods that extend 20 years into the future for technologies which may or may not have been fully developed. 
SECTION 2. CONVENTIONAL COAL FiRED POWERPLANT 


\section{CONVENTIONAL COAL FIRED POWERPLANT}

\subsection{CONVENTIONAL HIGH SULFUR COAL COMBUSTION WITH ADVANCED FLUE GAS DESULFURIZATION}

The reference, high-sulfur coal combustion system is a single-unit facility. The steam plant uses a cross compound, two parallel-shaft turbine generator, and has a net plant capacity of $1250 \mathrm{MWe}$. The basic steam cycle is modeled after a 1232 MWe concept designed by United Engineers and Constructors, as described in their reports "Commercial Electric Power Cost Studies," (1) and "Satellite Power System and Alternative Technology Characterization." (2) The United Engineers' design utilizes a conventional lime flue gas desulfurization system for stack gas cleaning and a mechanical draft cooling tower for condensate heat removal. At the time of its design (1977), this system met the Environmental Protection Agency (EPA) new source performance standard (NSPS) for $\mathrm{SO}_{2}$ emissions of $1.21 \mathrm{~b} / 10^{6} \mathrm{Btu}$ by scrubbing about $88 \%$ of the flue gas at a $90 \%$ removal efficiency. More recent EPA regulations, require a $90 \%$ removal of all $\mathrm{SO}_{2}$ stack gas for a facility of this type, and total $\mathrm{SO}_{2}$ are not to exceed an upper limit of $1.21 \mathrm{~b} / 10^{6} \mathrm{Btu}$. (3)

The characterization provided here is that of a projected year (2000), high-sulfur coal combustion technology and $\mathrm{SO}_{2}$ removal process. The plant capacity factor is assumed to be $70 \%$. It is also assumed that all of the plant's stack gases are processed to remove $90 \%$ of the $\mathrm{SO}_{2}$. Although it is possible to achieve this removal efficiency with conventional wet lime scrubbers, we considered advances in. $\mathrm{SO}_{2}$ removal systems anticipated between now and the year 2000. Thus, the reference high-sulfur coal facility for the year 2000 is assumed to use a Wellman-Lord $\mathrm{SO}_{2}$ removal system. The WellmanLord process has recently been demonstrated by the EPA ${ }^{(4)}$ and it is expected that this or a similar technology will be the preferred option in the year 2000 time frame. The Wellman-Lord system reduces land area requirements, the assumption of processing all stack gases decreases the net plant efficiency. Thus, the plant capital costs relative to the United Engineers design is increased. These factors have been fully accounted for in the characterization provided here. 


\subsection{GENERAL PLANT CONFIGURATION}

Figure 2-1 shows the basic plot arrangement for the reference, high-sulfur coal facility. The predominant structures are identified: the boiler house, turbine hall, and $\mathrm{SO}_{2}$ removal area. Two circular mechanical draft cooling towers and the electrical switchyard are located several hundred feet from the main generation facility. The largest onsite area. is the coal storage piles which typically store a total of 60-day coal supply. (5) $5 \%$ of which ie constdered active storage. The remainder is held as reserve, or dead storage, to guard against mining strikes or other supply interruptions. Other onsite structures include access roads, railroad spurs, and miscellaneous 3 torage tanks and settling basins. The layout shown includes site provisions for an. optional doubling of the plant capacity in the future. Space requirenents for these additional facilities are shown by the broken lines on the plot plan.

Although the elemental sulfur produced as a byproduct of the Wellman-Lord $\mathrm{SO}_{2}$ removal system could be a marketable comodity, this characterization assumes that the market conditions for sulfur are unfavorable and that the sulfur byproduct is disposed of in an appropriately prepared disposal site remote from the primary plant site. (6) Land area requirements for the primary site and sulfur disposal are discussed later in this section.

Coal is delivered via unit train to the fuel handling area adjacent to the coal storage piles. The fuel handling system has all of the necessary equipment to handle the coal gondolas in which the coal is supplied, including facilities for thawing the cars in winter and rotary car dumper. From the storage piles, the coal is moved by front end loaders to a conveyor system and on to the dryers, crushers, and pulverizers before being fed to the combustion furnace boilers along with preheated air. High pressure steam produced in the boilare 13 used to power the turbine generator equipment to produce a net plant capacity of 1250 MWe. Flue gases are processed through electrostatic precipitators to remove $99.7 \%$ of the flyash particulates and through a Wellman-Lord $\mathrm{SO}_{2}$ removal system before being reheated with an in-stack, steam-to-flue gas heat exchanger and discharged to the atmosphere through a 750 foot high, steellined stack. 


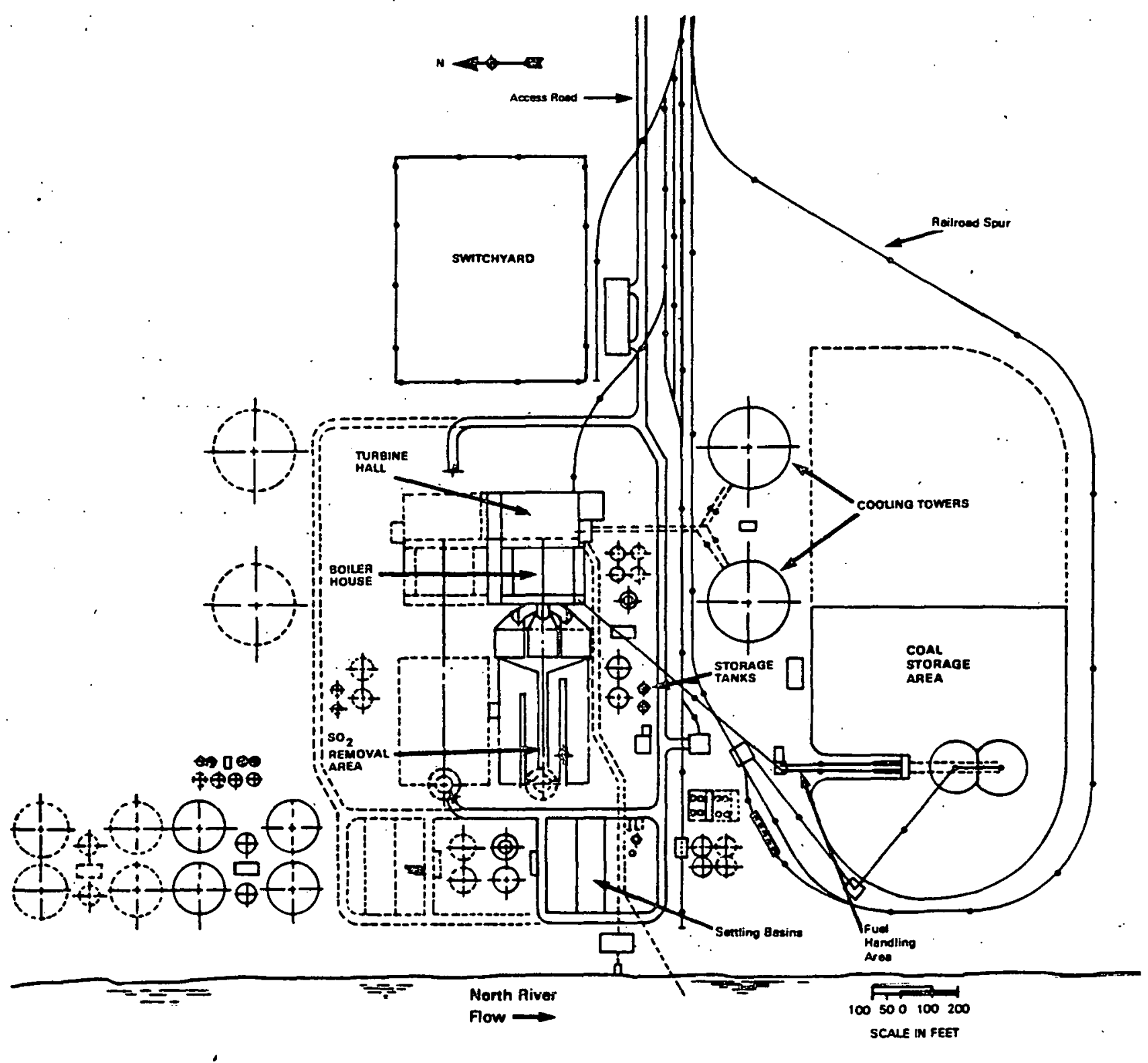

Figure 2-1. Plot Plan - 1250 MWe Reference High Sulfur Coal System 
Boiler solid waste, bottom ash, is removed by an ash handling system. Afterwards, the waste is quenched and combined with the flyash. Then the ash sludge is routed to an onsite settling pond for temporary storage and dewatering. Finally, the ash sludge and the elemental sulfur are removed from the $\mathrm{SO}_{2}$ removal system.

The main condenser heat rejection system includes a makeup water intake and discharge, circulating water pump, and two mechanlcal draft wet cooling towers. Waste heat from the thermodynamic cycle is rejected to the main condenser in the form of heated water. Cooler water from the cooling towers circulates through the condenser to remove this heat and rejects it to the atmosphere in the form of convective and evaporative losses. 


\subsection{THERMODYNAMIC CYCLE CHARACTERISTICS $(7)$}

The reference, high-sulfur coal generation facility is fired with an Eastern bituminous coal which, as received, has a higher heating value (HHV) of $11,026 \mathrm{Btu} / \mathrm{1b}$ and other constitutents as shown in Table 2-1. The overal1 net plant efficiency, which accounts for in-plant auxiliary steam and electrical consumption, is 35.75. This facility requires $9546 \mathrm{Btu}$ 's of coal feed to produce one kilowatt hour of electricity. Figure 2-2 displays the major pieces of plant equipment in a simplified cycle schematic and energy flow diagram of the reference design. Each of the major components is described in the following paragraphs.

\subsection{COMBUSTION FURNACE BOILER}

With a pulverized coal feed of $11,932.7 \times 10^{6} \mathrm{Btu} / \mathrm{hr}$, or 541.1 tons/hr at $11,026 \mathrm{Btu} / \mathrm{Ib}$, the combustion furnace boiler produces $9.69 \times 10^{6} \mathrm{lb} / \mathrm{hr}$ of high-pressure steam at $3845 \mathrm{psig}$ and $1010^{\circ} \mathrm{F}$ at the superheater outlet. This is accomplished using an equivalent flow of feedwater at a temperature of $547^{\circ}$. Exit. steam from the boiler is expanded through the high-pressure turbine which has steam inlet conditions of 3515 psig and $1000^{\circ} \mathrm{F}$. A total of $7.93 \times 10^{6} \mathrm{bb} / \mathrm{hr}$ of steam at $565^{\circ} \mathrm{F}$ and $653 \mathrm{psig}$ is removed from the highpressure turbine outlet and returned to the boiler steam reheaters where it is heated to $1000^{\circ} \mathrm{F}$ and $600 \mathrm{psig}$ before it is expanded through the intermediate pressure turbine. Exit steam not returned to the boiler reheaters, approximately $1.76 \times 10^{6} \mathrm{lb} / \mathrm{hr}$, is extracted at $672^{\circ} \mathrm{F}$ and used primarily for feedwater heating.

Total heat to steam in the boiler and reheaters is $10,560 \times 10^{6} \mathrm{Btu} / \mathrm{hr}$ on a coal feed of $11,932.7 \times 10^{6} \mathrm{Btu} / \mathrm{hr}$, or an $88.5 \%$ boiler/reheater efficiency. Boilers of similar characteristics and heat-to-steam efficiencies are currentIy marketed by Combustion Engineering and other major boiler manufacturers.

\subsubsection{Turbine Generator Configuration}

Turbine shaft power totaling $4735.2 \times 10^{6} \mathrm{Btu} / \mathrm{hr}$ or $1,387,400 \mathrm{~kW}$ is produced with throttle steam conditions of 3515 psig and $1000^{\circ} \mathrm{F}$ superheated steam (at the inlet to the high pressure turbine) and $600 \mathrm{psig}$ at $1000^{\circ} \mathrm{F}$ (at the inlet to the intermediate pressure turbine). The turbine configuration is a cross compound: two parallel-shaft machines with an elght flow low-pressure 
Table 2-1. Typical Eastern High Sulfur Coal Characteristics

\begin{tabular}{|c|c|c|}
\hline Property or Component & As Received & Dry \\
\hline 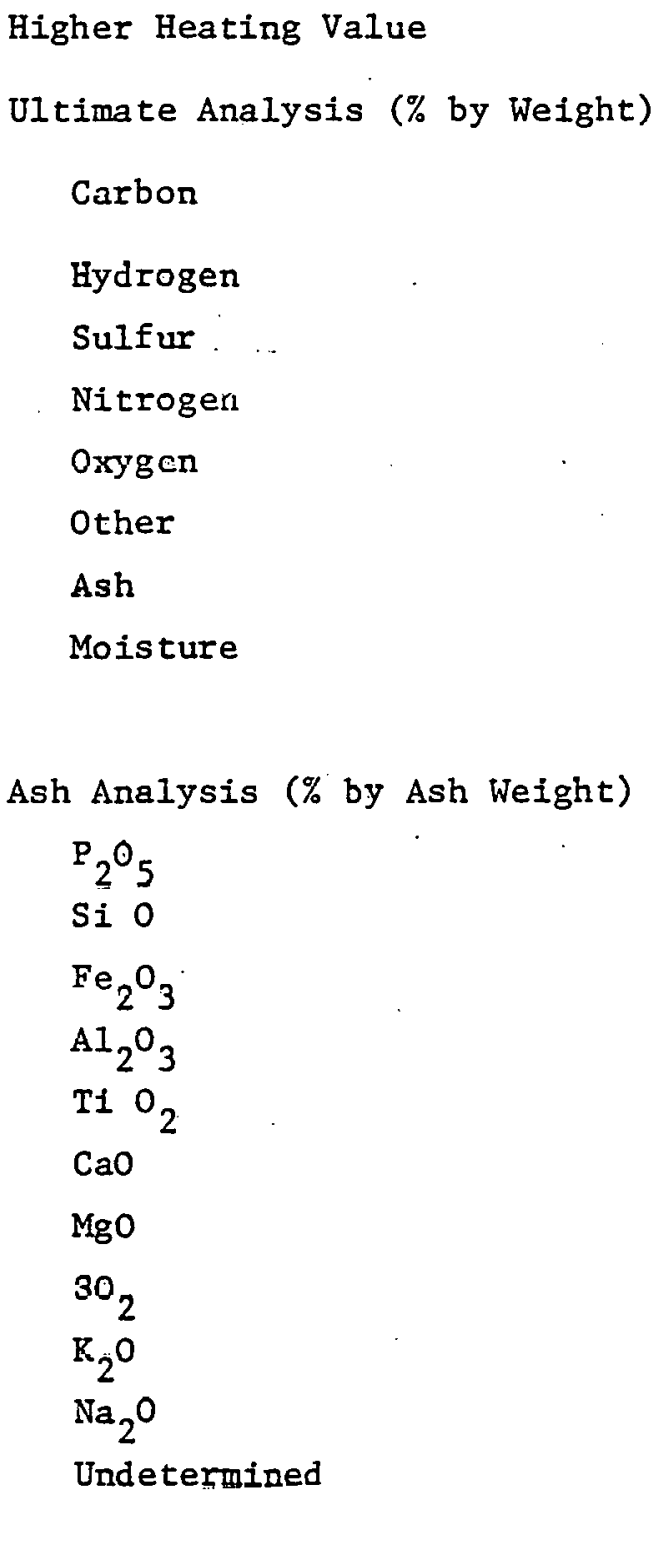 & $\begin{array}{r}11,026 \mathrm{Btu} / 1 \mathrm{~b} \\
61.49 \\
3.81 \\
3.20 \\
.76 \\
8.55 \\
.59 \\
10.29 \\
11.31 \\
100.00\end{array}$ & 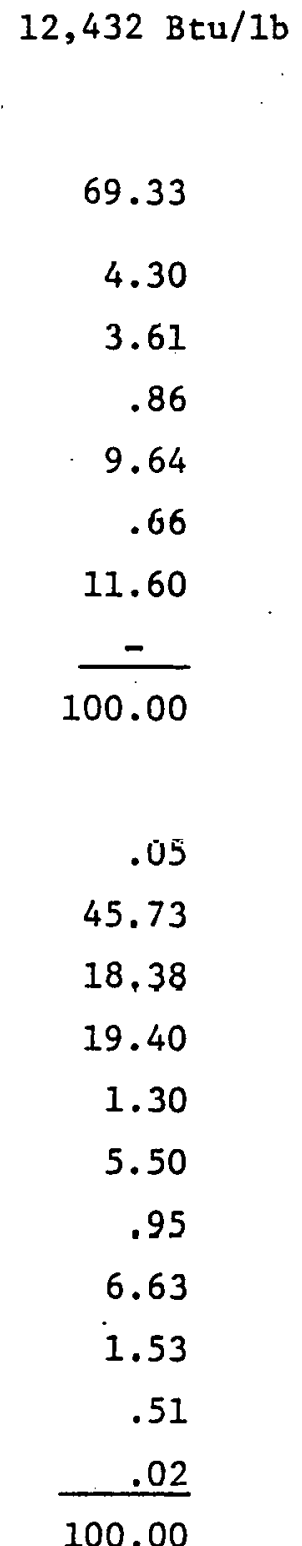 \\
\hline
\end{tabular}

Source: Reference 2, P. 2.2-5 


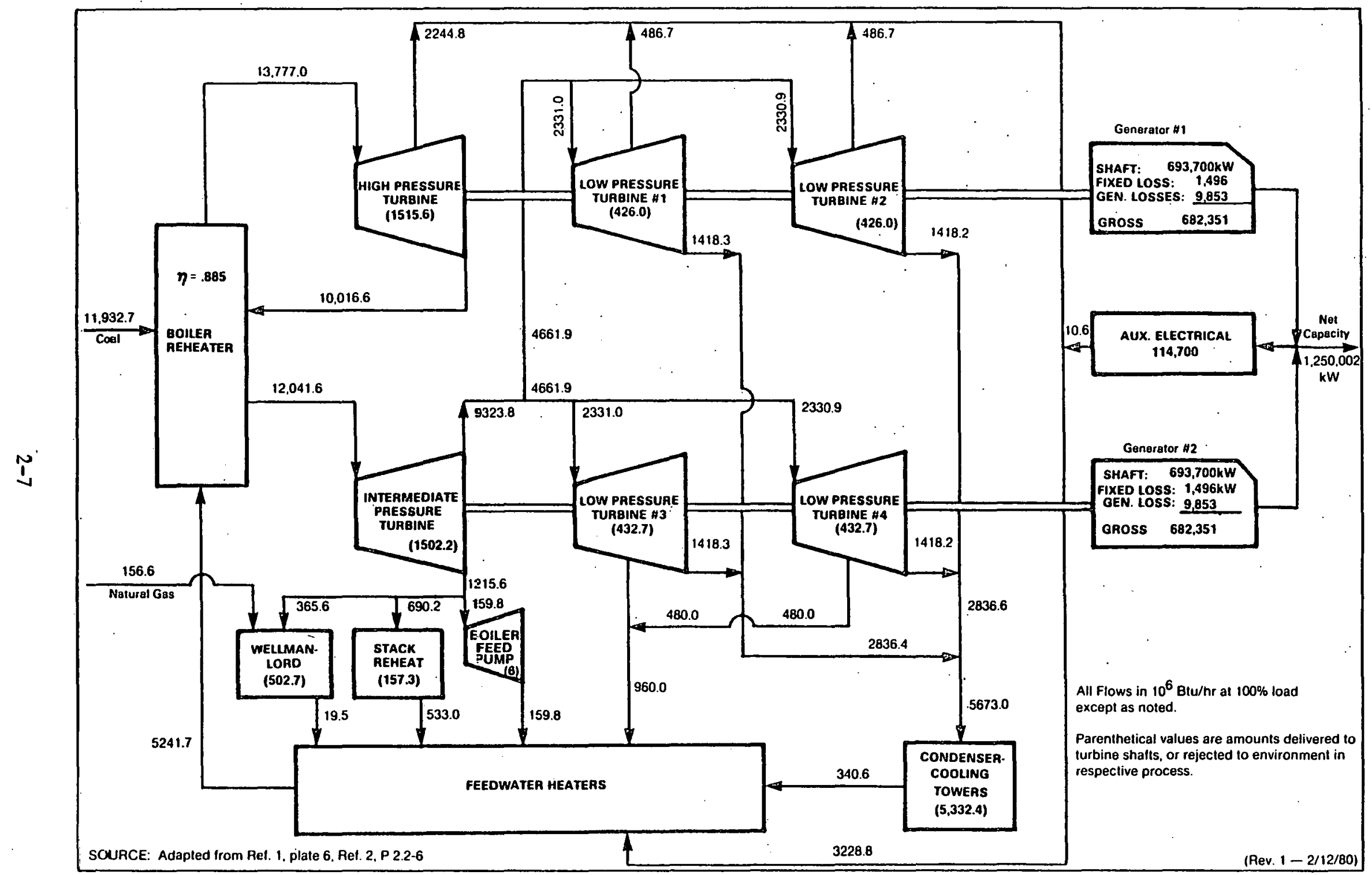

Figure 2-2. Simplified Schematic of High-Sulfur Coal Generation Facility 
turbine exhausting to the condenser (four only, as shown previously in Figure 2-2 schematic) and using 30-inch last-stage turbine blades designed for 3600 revolutions per minute (rpm). As shown in Figure 2-2, one shaft consists of one high-pressure turbine and two low-pressure turbines driving an electric generator. A second, parallel shaft consists of one intermediatepressure turbine and two low-pressure turbines driving an electric generator.

Turbine shaft power and generator output is about equally distributed to the two shafts. Each of the two generators is rated at $722 \mathrm{MVA}$ with $0.90 \mathrm{PF}$, $26,000 \mathrm{~V}, 3$ phase and $60 \mathrm{~Hz}$ output. Fixed and generation losses respectively account for $1,496 \mathrm{~kW}$ and $9,853 \mathrm{~kW}$ per generator, thus resulting in a gross generator output capacity of $1,364,702 \mathrm{~kW}$, before accounting for auxiliary electrical loads.

The steam flow configuration through the turbines begins with highpressure steam entering the high-pressure turbine on the upper shaft displayed in Figure B-2. As this steam is expanded through the turbine, it imparts about $1515.6 \times 10^{6} \mathrm{Btu} / \mathrm{hr}(444,066 \mathrm{~kW})$ to the turbine generator shaft. Some $18 \%$ of the inlet steam flow is extracted and used in the final feedwater heating stage, with the remainder $(82 \%)$ being returned to the boiler reheaters.

From the boiler reheaters, intermediate-pressure steam is expanded through the intermediate-pressure turbine on the lower turbine generator shaft. There, $1502.2 \times 10^{6} \mathrm{Btu} / \mathrm{hr}(440,140 \mathrm{~kW})$ is given up to the turbine shaft before being extracted for various in-plant uses or as feed streams to the four low-pressure turbines. The various in-plant steam uses primarily include $161.18 \times 10^{6} \mathrm{Btu} / \mathrm{hr}$ to power the boller feed pump turbine, $365.6 \times 10^{6}$ $\mathrm{Bru} / \mathrm{hr}$ to convert sodium bisulfate to sodium sulfite in the Wellman-Lord $\mathrm{SO}_{2}$ removal system, and a net of $157.3 \times 10^{6} \mathrm{Btu} / \mathrm{hr}$ to reheat about $13.0 \times 10^{6}$ $\mathrm{lb} / \mathrm{hr}$ of stack gases from $125^{\circ} \mathrm{F}$ to $175^{\circ} \mathrm{F}$. As shown in the figure, residual energy from these auxiliary steam flows is then uscd for feedwater healing.

Twenty-five percent of the remaining $9,323.8 \times 10^{6} \mathrm{Btu} / \mathrm{hr}$ of steam, which was extracted from the intermediate pressure turbine at its final stage outlet, is used to power each of four low-pressure turbines. The low pressure turbines on the upper (or high-pressure) turbine shaft each receive $426.0 \times 10^{6} \mathrm{Btu} / \mathrm{hr}$ $(124,817 \mathrm{~kW})$ of energy at the turbine shaft and reject $1.430 \times 10^{6} \mathrm{Btu} / \mathrm{hr}$ to the condenser. Low-pressure turbines on the lower or intermediate-pressure turbine shaft each receive $432.7 \times 10^{6} \mathrm{Btu} / \mathrm{hr}(126,780 \mathrm{~kW})$ at the turbine 
shaft and reject about the same amount of waste heat to the condenser system. Low pressure turbine steam energy not imparted to the turbine shafts or rejected to the condenser is extracted and used primarily for feedwater heating.

\subsubsection{Condenser-Heat Rejection System}

Two multipressure, single pass surface condensers--with divided fabricated steel water boxes and shell--are used to condense the low-pressure turbine outlet steam by dissipating to two mechanical draft wet cooling towers. Each cooling tower is sized for one-half of the heat rejection requirements. Designed to $\operatorname{cool} 231,400$ gallons per minute from $118^{\circ} \mathrm{F}$ to $92^{\circ} \mathrm{F}$ for a wet bulb temperature of $74^{\circ} \mathrm{F}$, each cooling tower houses 13 fans measuring 33 feet in diameter. Under full load conditions $95 \%$ of the heat dumped to the condenser, or $5332.4 \times 10^{6} \mathrm{Btu} / \mathrm{hr}$, is rejected to the atmosphere by the cooling water sys tem.

\subsubsection{Feedwater Heaters}

Feedwater flow from the condenser enters a series of eight reverse cascade feedwater heaters designed to achieve a final feedwater flow of $9.69 \times 10^{6} 1 \mathrm{~b} / \mathrm{hr}$ at $547^{\circ} \mathrm{F}$. As mentioned previously, numerous turbine extractions and other residual steam flows are utilized in the feedwater heating stage of the steam cycle. A total of $4901.1 \times 10^{6} \mathrm{Btu} / \mathrm{hr}$ is added to the condenser outflow of $340.6 \times 10^{6} \mathrm{Btu} / \mathrm{hr}$ resulting in $5241.7 \times 10^{6} \mathrm{Btu} / \mathrm{hr}$ final feedwater flow to the boiler. A small amount of energy is also added to feedwater steam from electrical pump thermal losses particularly from the condensate and condensate booster pumps.

\subsubsection{Generator Losses and Auxiliary Electric Energy Use}

Aggregate turbine shaft power totals $1,387,400 \mathrm{~kW}$. Various generator inefficiencies result in the loss of $22,698 \mathrm{~kW}$ or $1.64 \%$ of the shaft power as fixed and generation power losses. Of the remaining $1,364,702 \mathrm{~kW}$, a total of $114,700 \mathrm{~kW}$ or $8.40 \%$ is used for auxilfary electrical uses within the plant, leaving 1,250,014 $\mathrm{kW}$ of net plant generation. Table 2-2 details the auxiliary power requirements for the reference, high-sulfur coal facility.

The fractional power requirement for in-plant auxiliary electrical uses is somewhat higher than what is typically reported for conventional coal generation facilities. The primary reason for this is the high power requirements for the electrostatic precipitators and the Wellman-Lord flue gas 
Table 2-2. Auxiliary Electric Power Requirements Reference 1250 MWe High-Sulfur Coal Facility

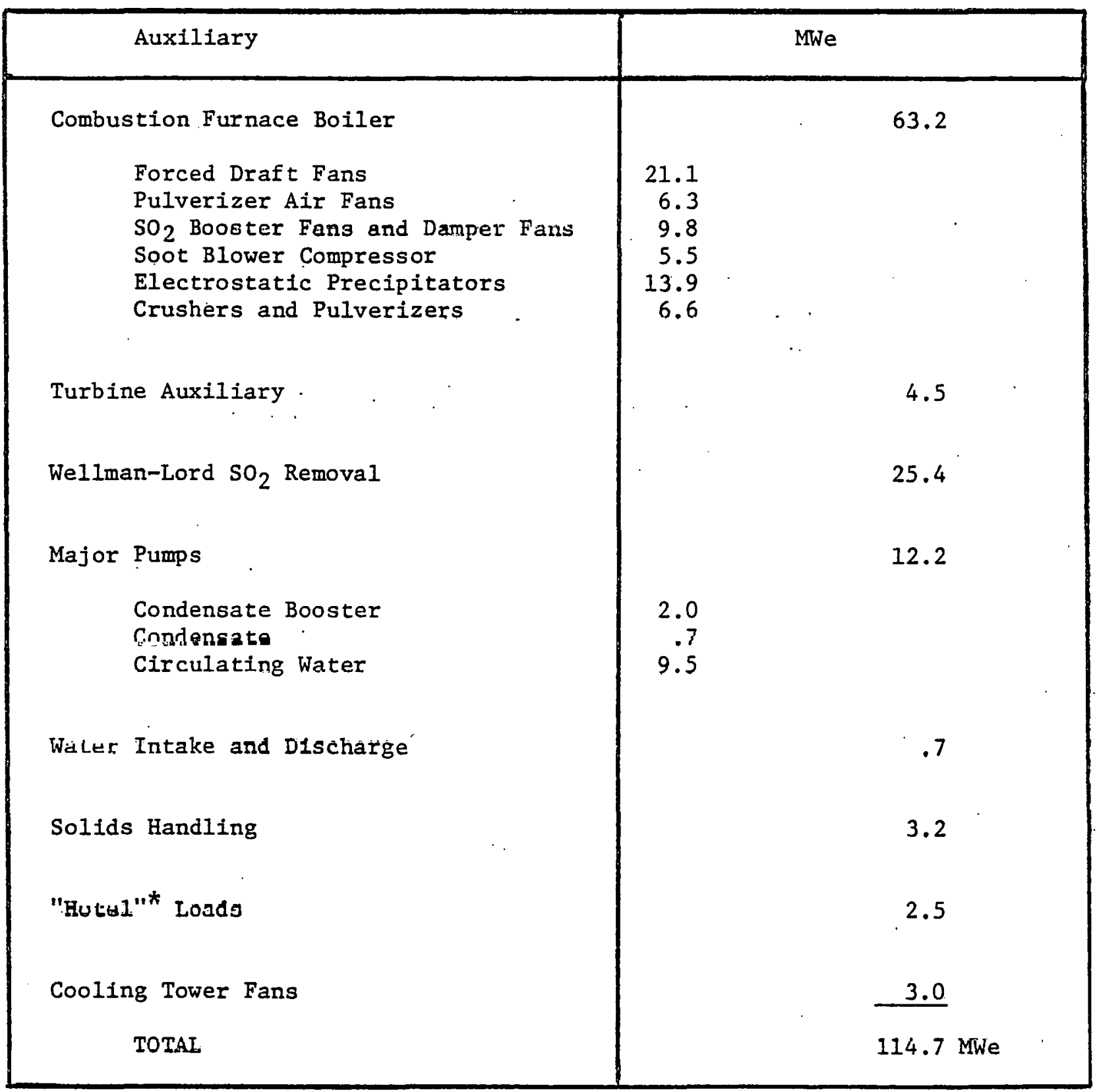

Miscellaneous plant loads not itemized, based, in part, on an analysis of Nuclear plant Hotel loads. Reference 9.

Source: Adapted from Reference 1 and Reference 9 
desulfurization system. For example, conventional wet-lime scrubbers would need about 11.3 MWe for a plant of this size. The Wellman-Lord system, however, has a power requirement of 25.4 MWe. Also, the electrostatic precipitators (ESP) for flyash removal have been sized for $99.7 \%$ flyash removal efficiency as opposed to a more conventional removal efficiency of $98.6 \%$. As power requirements for ESP flyash removal are proportional to $10 g$ (1-f) where $f$ is the fractional collectional efficiency, the assumed increase of $1.1 \%$ collection efficiency increases the ESP power requirement by slightly more than $36 \%$ over the conventional system requirements. (8) other factors which tend to increase inplant power uses result from added steam, air, and coal handling requirements that are necessary to support the auxiliary steam uses for stack gas reheating, and the Wellman-Lord $\mathrm{SO}_{2}$ removal system, as well as the gross flows needed to support the added inplant electrical uses. Added steam and air and material flows increase inhouse power requirements for fans, pumps, and solids handling equipment by $5.2 \%$ to maintain the same net generation capacity.

\subsubsection{Fuels Use and Logistics}

The reference, high-sulfur coal generation facility uses a typical eastern high-sulfur bituminous coal to generate a net capacity of 1250 MWe with an assumed capacity factor of $70 \%$. A detailed heat balance shows that 9,546 Btu's of pulverized coal is required to generate one net kilowatt hour of net output; this corresponds to a net plant efficiency of $35.75 \%$. The coal characteristics chosen assume a higher heating value of $11,026 \mathrm{Btu} / \mathrm{Ib}$ of coal on an as-received basis. At full capacity, coal, feed is required at a rate of 541.1 tons/hour or $3.32 \times 10^{6}$ tons/year at $70 \%$ capacity factor. At this rate, an average of 9,090 tons of coal would be delivered to the site each day. Because coal storage requirements are estimated at full capacity factor, a 3-day live storage stock pile would contain 38,960 tons of coal, and a 57-day reserve storage would contain 740,225 tons of coal.

The average storage density of utility coal in live storage is 960 tons/ acre-ft, and reserve storage density averages 1176 tons/acre-ft. (10) These data assume that 30 foot high active storage and 50 foot high reserve storage results in a site area of 14 acres devoted to coal storage alone. 
Other fuel in the form of natural gas is also required for processing $\mathrm{SO}_{2}$ gas from the Wellman-Lord scrubber system to elemental sulfur. This process requires about $156.6 \times 10^{6} \mathrm{Btu} / \mathrm{hr}$ of natural gas at full plant capacity or, at $70 \%$ capacity factor and $1,000 \mathrm{Btu} / \mathrm{ft}^{3}$ of gas, about $960.3 \times 10^{6} \mathrm{ft}^{3}$ of natural gas per year: (11) This fuel requirement is discussed in more detail under the description of the Wellman-Lord flue gas desulfurization system. Table 2-3 summarizes some of the reference plant parameters. 
Table 2-3. Key Plant Parameters - 1250

MWe High-Sulfur Coal Plant

\begin{tabular}{|c|c|}
\hline Parameters & Operating Description \\
\hline Steam Generator & $\begin{array}{l}\text { Supercritical pressure, } \\
\text { single reheat with a } \\
\text { Pressurized Furnace }\end{array}$ \\
\hline $\begin{array}{l}\text { Steam Flow } \\
\quad \text { Maximum Continuous Rating, } 10^{6} \mathrm{lb} / \mathrm{hr} \\
\text { Normal Superheater Outlet, }{ }^{10} \mathrm{lb} / \mathrm{hr} \\
\text { Normal Reheater Outlet, } 10^{1 \mathrm{~b} / \mathrm{hr}}\end{array}$ & $\begin{array}{r}10.36 \\
9.69 \\
7.93\end{array}$ \\
\hline $\begin{array}{l}\text { Steam Pressure } \\
\text { Superheater Outlet, psig } \\
\text { Reheater Outlet, psig }\end{array}$ & $\begin{array}{r}3,845 \\
650\end{array}$ \\
\hline $\begin{array}{l}\text { Steam Temperature } \\
\text { Superheater Outlet, }{ }^{\circ} \mathrm{F} \\
\text { Reheater Outlet, }{ }^{\circ} \mathrm{F}\end{array}$ & $\begin{array}{l}1,010 \\
1,000\end{array}$ \\
\hline Final Feedwater Temperature, ${ }^{\circ} \mathrm{F}$ & 547. \\
\hline Fuel Type & $\begin{array}{l}\text { Eastern Bituminous Coa1 } \\
\text { @ } 11026 \mathrm{Btu} / \mathrm{Ib}, 10.29 \% \\
\text { ash, } 3.2 \% \text { sulfur }\end{array}$ \\
\hline Fuel Firing Rate, Ton/Hr at full load & 541.1 \\
\hline Fuel Analysis & See Table B-1 \\
\hline Number of Pulverizers & 6 plus 1 spare \\
\hline Pulverizer Fuel Flow, Tons/Hr & 90.2 \\
\hline Number of Forced Draft Fans & 33 \\
\hline Total Forced Draft Fan, Capacity, scfm & $2,160,000$ \\
\hline Number of Primary Air Fans & 2 \\
\hline Total Primary Air Fan Capacity, scfm & 540,000 \\
\hline Number of Precipitators & 3 \\
\hline Precipitator Efficiency, in percent & 99.7 \\
\hline Turbine Configuration & Cross Compound, 8 Flow \\
\hline Steam Flow at HP Turbine Inlet, $10^{6} \mathrm{Ib} / \mathrm{hr}$ & 9.69 \\
\hline Steam Pressure at uP Turbine Inlet, psia & 3,515 \\
\hline
\end{tabular}


Table 2-3. Key Plant Parameters - 1250 MWe

High-Sulfur Coal Plant (Continued)

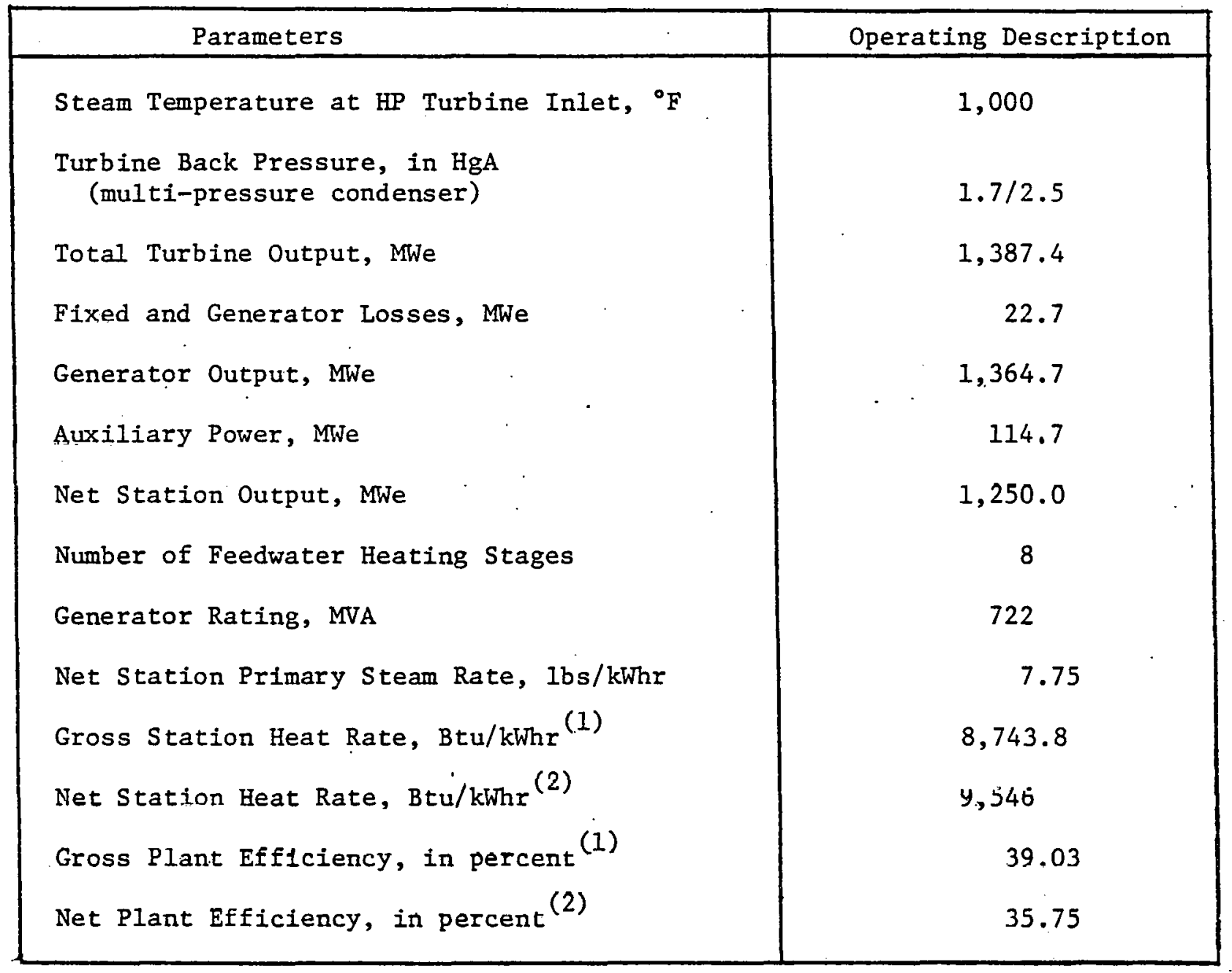

${ }^{(1)}$ Gross is before auxiliary electric uses

(2) Net is after auxiliary electric uses

Source: Adapted from References 1, 2, 12. 


\subsection{ENVIRONMENTAL CHARACTERISTICS}

\subsection{ELECTROSTATIC PRECIPITATORS}

The reference, high-sulfur coal facility has been designed with hot electrostatic precipitators sized for the removal of $99.7 \%$ of the flyash particulates emitted from the combustion furnace boiler. The flow rate of the flue gas processes is approximately $13 \times 10^{6} \mathrm{lb} / \mathrm{hr}$ at full load. Thus, 13.9 MW of auxiliary electric power is required for effective operation of the electrostatic precipitators. $(8,12,13)$

The combustion of $1,082,233$ pounds of coal per hour with an ash content of $10.29 \%$ by weight produces $89,089 \mathrm{ib} / \mathrm{hr}$ of flyash based on an $80 \%$ flyash, $20 \%$ bottom ash $(22,273 \mathrm{lb} / \mathrm{hr})$ proportion. Removal of $99.7 \%$ of this amount results in a total of $267 \mathrm{lb} / \mathrm{hr}$ of flyash, which is sent downstream for further processing in the Wellman-Lord $\mathrm{SO}_{2}$ removal system.

Flyash removed by the precipitators is quenched with water combined with the bottom ash and disposed of as $20 \%$ water, $80 \%$ ash solids. (14) Thus, the sludge wastes from the electrostatic precipitators and bottom ash totals $138,869 \mathrm{lb} / \mathrm{hr}$ for the $1250 \mathrm{MN}$ reference coal facility at $100 \%$ capacity.

It should be noted that the electrostatic precipitators assumed to be installed in this reference facility could easily meet current EPA standards for particulate emissions without further processing of particulates in the initial stage of the Wellman-Lord system. The $267 \mathrm{Ib} / \mathrm{hr}$ of flyash in the electrostatic precipitator exit stream corresponds to the combustion of $11,932.7 \times 10^{6}$ Btu of coal or an exit stream particulate rate of 0.022 $1 \mathrm{~b} / 10^{6} \mathrm{Btu}$. Current EPA regulations call for particulate emissions not greater than $0.031 \mathrm{~b} / 10^{6} \mathrm{Btu}$.

To meet current EPA regulations for particulate emissions after an additional $70 \%$ removal is achieved in the Wellman-Lord system, the electrostatic precipitators need to be designed to remove only $98.7 \%$ of the flyash particulates. This reduction in collection efficiency would have a corresponding reduction in in-house auxiliary power requirements of $3500 \mathrm{~kW}$ (or about $3 \%$ of what is currently assumed for the reference facility). Thus, the design characteristics assumed here, which are achievable with current technology, are conservative in terms of their affect on the plant heat rate and costs. 
In other words, these assumptions tend to reduce overall plant efficiency and thus increase total generating costs.

\subsection{WELLMAN-LORD FLUE GAS DESULFURIZATION}

Downstream from the electrostatic precipitators is the Wellman-Lord flue gas desulfurization system. This system uses a regenerable process in which sulfur dioxide, $\mathrm{SO}_{2}$, is removed from flue gases with a sodium sulfite scrubbing solution. The concentrated $\mathrm{SO}_{2}$ stream that is produced can be processed into elemental sulfur or sulfuric acid, both of which may be marketable industrial products.

There are currently more than 24 operating Wellman-Lord installations in Llie Unlted Staces and Japan. Most nntable is the Wellman-Lord installation at the Northern Indiana Public Service Company's P. H. Mitchell Station in Gary, Indiana, which is this Nation's first application of the Wellman-Lord process on a coal-fired boiler. This system is currently demonstrating $\mathrm{SO}_{2}$ removal efficiencies greater than $90 \%$.

The Wellman-Lord process consists of four basic steps as shown schematically in Figure 2-3. These steps include:

1. Flue gas pretreatment

2. $\mathrm{SO}_{2}$ absorption

3. Purge treatment

4. Sodium sulfite regeneration

A fifth step, the processing of $\mathrm{SO}_{2}$ into marketable sulfur byproducts, is not part of the Wellman-Lord process, but is generally associated with WellmanLord installations.

In the first process step, botler flue gas is pretreated by contact with water in a venturi prescrubber. This step cools and saturates the gas, absorbs" corrosive chlorides, and then removes $70 \%$ or $187 \mathrm{lb} / \mathrm{hr}$ of the flyash particulates remaining in the gas after upstream particulate removal by the electrostatic precipitators. This is disposed of as an $80 \%$ solids sludge at a rate of $234 \mathrm{lb} / \mathrm{hr}$. Only $80 \mathrm{lb} / \mathrm{hr}$ of particulates remain in the flue gas stream after pretreatment in the venturi prescrubber. 


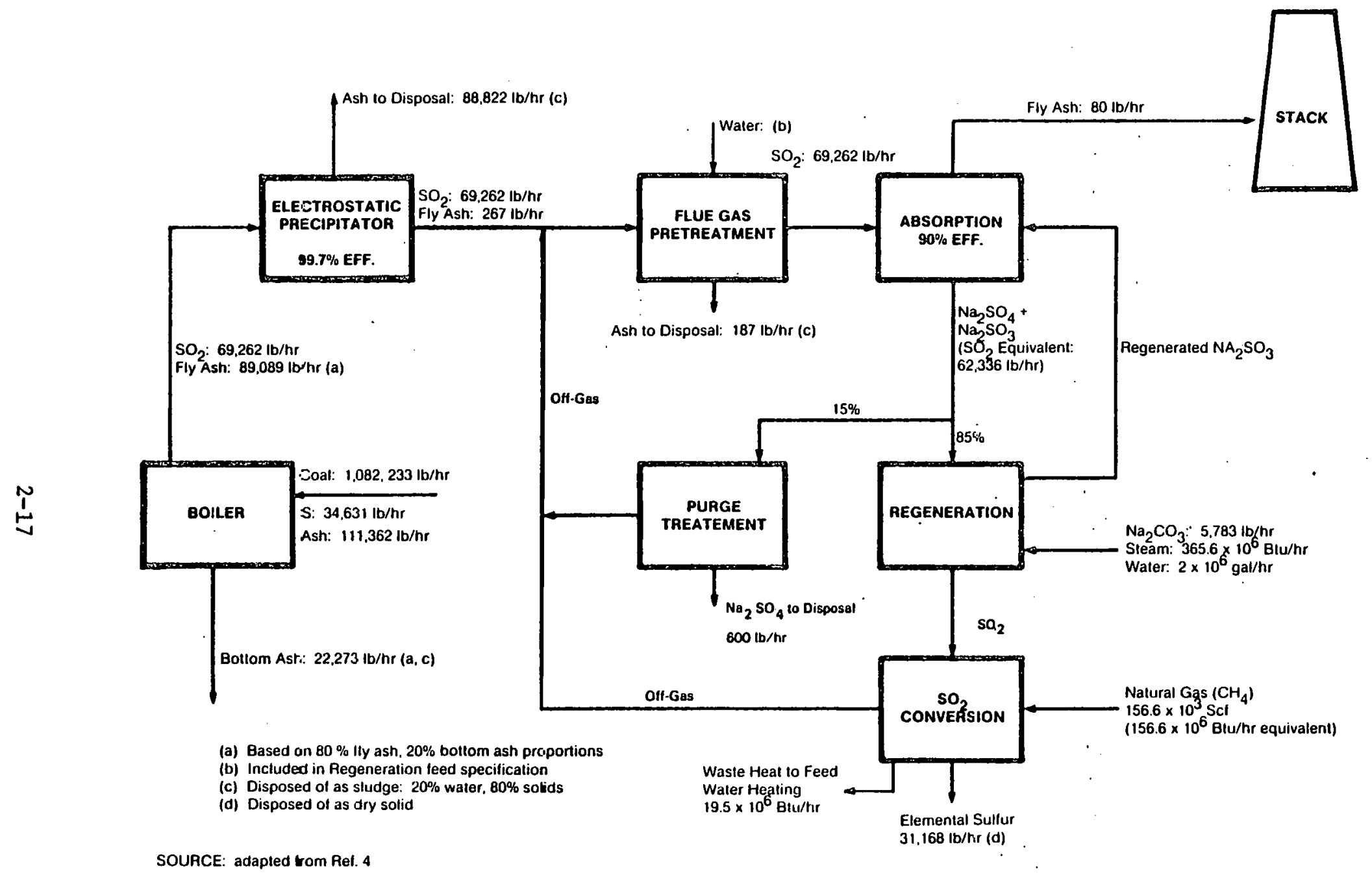

Figure 2-3. Wellman-Lord Process 
After pretreatment, the flue gas then flows to an absorber where it is contacted with a sodium sulfite solution. The $\mathrm{SO}_{2}$ in the flue gas reacts with the sodium sulfite to produce sodium bisulfite. In a side reaction, some sodium sulfate is formed by direct oxidation of sodium sulfite.

At least $90 \%$ of the $\mathrm{SO}_{2}$ in the flue gas stream is removed in the absorption stage; the remaining $10 \%$ is emitted to the atmosphere. Combustion of $1,082,233 \mathrm{lb} / \mathrm{hr}$ of coal with a sulfur content of $3.2 \%$ and $90 \%$ removal results in the emission of $6,926 \mathrm{lb} / \mathrm{hr}$ of $\mathrm{SO}_{2}$, or an equivalent of $0.58 \mathrm{lb} / 10^{6} \mathrm{Btu}$ of $\mathrm{SO}_{2}$. This desulfurized flue gas leaves the absorber at a temperature of $125^{\circ} \mathrm{F}$ and is reheated with an instack, steam heat exchanger to $175^{\circ} \mathrm{F}$ before it is exhausted to the atmosphere.

The effluent from the absorption tower, rich in sodium bisulfate and sodium sulfate, is split into two streams. Approximately $15 \%$ of the effluent is routed to a purge treatment for sulfate removal; the remaining $85 \%$ goes to a regeneration process.

The purge stream is cooled in a chiller and a mixture of sodium sulfate and sodium sulfite is crystallized out of the solution. This crystalline mixture is removed from the process and dryed for sale or disposal. For the reference 1250 MWe coal facility burning $3.2 \%$ sulfur coal, the combined sodium sulfate and sodium sulfite waste would be generated at a rate of $6000 \mathrm{lb} / \mathrm{hr}$.

Although this sodium sulfate/sodium sulfite byproduct has a somewhat limited economic value, a potential market may exist in the paper industry where it may be used to replenish sulfur in the pulping liquor. This characterization, however, assumes that the dryed byproduct is disposed of along with the ash sludge, elemental sulfur, and other waste or byproducts.

Regeneration is accomplished in an evaporator for $85 \%$ of the absorption tower outlet stream that goes to the regeneration step. The effluent in the evaporator is heated to convert sodium bisulfate to sodium sulfite and to drive off sulfur dioxide. For the reference coal system, $365.6 \times 10^{6} \mathrm{Btu} / \mathrm{hr}$ of steam is extracted from the steam cycle to provide the necessary heating requirements. The regenerated sodium sulfite is dissolved and recycled to the absorber. Sodium lost during the purge operation is replenished by adding $5783 \mathrm{lb} / \mathrm{hr}$ of sodium carbonate and water to the feed dissolving tank. 
The fifth step, $\mathrm{SO}_{2}$ processing, uses the sulfur dioxide byproduct from the Wellman-Lord process. The outlet stream from the regeneration evaporator is about $85 \% \mathrm{SO}_{2}$ and $15 \%$ water vapor. This concentrated $\mathrm{SO}_{2}$ stream may be dried and marketed without further processing. Then the concentrated $\mathrm{SO}_{2}$ stream is either reduced to elemental sulfur or oxidized and reacted with water to form sulfuric acid. Here, an Allied Chemical Corporation process for conversion of $\mathrm{SO}_{2}$ to elemental sulfur has been integrated with the WellmanLord flue gas desulfurization system. The Allied process would use 156.6 thousand cubic feet of natural gas per hour $\left(156.6 \times 10^{6} \mathrm{Btu} / \mathrm{hr}\right)$ as a reductant. A proprietary catalyst converts the $\mathrm{SO}_{2}$ gas stream to elemental sulfur, thereby liberating carbon dioxide and water. By this process, $31.168 \mathrm{lb} / \mathrm{hr}$ of elemental sulfur would be produced at $100 \%$ capacity. As mentioned previously, this byproduct is assumed to be disposed of in clay-lined disposal basins rather than marketed.

The conversion of $\mathrm{SO}_{2}$ to elemental sulfur is an exothermic reaction and would liberate approximately $19.5 \times 10^{6} \mathrm{Btu} / \mathrm{hr}$. In the reference coal design, this energy is assumed to be used for feedwater heating. Overall, a $90 \%$ removal of $\mathrm{SO}_{2}$ in the flue gas stream results in the ultimate emission of $6.926 \mathrm{lb} / \mathrm{hr}$ of $\mathrm{SO}_{2}$ to the atmosphere. This emission rate corresponds to $0.581 \mathrm{~b} / 10^{6}$ Btu of coal burned.

Table 2-4 summarizes the air residuals resulting from power generation of this system. Solid and sludge residuals and the environmental impacts associated with the coal fuel cycle are discussed in the following sections.

Table 2-4. Air Residuals - 1250 MWe Reference High-Sulfur Coal Generation

\begin{tabular}{|c|c|c|c|c|c|}
\hline \multirow[b]{2}{*}{ Pollutant } & \multicolumn{2}{|c|}{ 100\% Capacity Factor } & \multicolumn{2}{|c|}{$70 \%$ Capacity Factor } & \multirow[b]{2}{*}{$1 \mathrm{~b} / 10^{6} \mathrm{Btu}$} \\
\hline & $1 \mathrm{~b} / \mathrm{hr}$ & tons/yr & $1 \mathrm{~b} / \mathrm{hr}$ & tons/yr & \\
\hline $\mathrm{SO}_{2}$ & 6,926 & 30,336 & 4,848 & 21,234 & 0.58 \\
\hline Particulates & 80 & 350 & 56 & 245 & 0.007 \\
\hline $\mathrm{NO}_{x}$ & 7,160 & 31,360 & 5,012 & 21,953 & 0.6 \\
\hline
\end{tabular}




\subsection{SOLID WASTES AND SLUDGES}

Solid wastes and sludges result from power generation by the reference, high-sulfur coal facility. This in turn results from the disposal of wastes and byproducts recovered from the flue gas desulfurization and ash recovery systems.

At full capacity, 1,082,233 $\mathrm{lb} / \mathrm{hr}$ of coal composed of $10.29 \%$ ash and 3.2\% sulfur is fired in the combustion furnace boiler. A total of $90 \%$ of the input sulfur is recovered and disposed of in clay-lined disposal basins near the primary plant site. Thus, at $100 \%$ load, $31,168 \mathrm{lb} / \mathrm{hr}$ of elemental sulfur is processed for disposal.

Flyash constitutes about $80 \%$ of the total ash in the feed coal. Of this amount, $99.7 \%$ is recovered in the electrostatic precipitators. Seventy percent of the ash in the precipitator exit stream is then recovered by the Wellman-Lord prescrubber. With a total ash feed of $111,362 \mathrm{lb} / \mathrm{hr}$, only 80 . $\mathrm{lb} / \mathrm{hr}$ is emitted to the atmosphere; the remainder is recovered as bottom ash or by the flyash recovery systems. The recovered ash is quenched with water. Later, it is disposed of as $20 \%$ water and $80 \%$ ash sludge, wh1ch has a final settled density of $90.1 \mathrm{~b} / \mathrm{ft}^{3}$.

The only other significant solid waste stream results from the WellmanLord sodium sulfite purge system. This system produces a dry crystalline mixture of sodium sulfate and sodium sulfite at a rate of $6,000 \mathrm{lb} / \mathrm{hr}$. All solid and sludge wastes from the plant site are assumed to be disposed of near the site. Accumulation rates and land area requirements for disposal are summarized in Table 2-5 for the assumed plant capacity factor of $70 \%$.

Table 2-5. Solid and Sludge Wastes - 1250 MWe Reference High-Sulfur Coal Generation - 70\% Capacity Factor

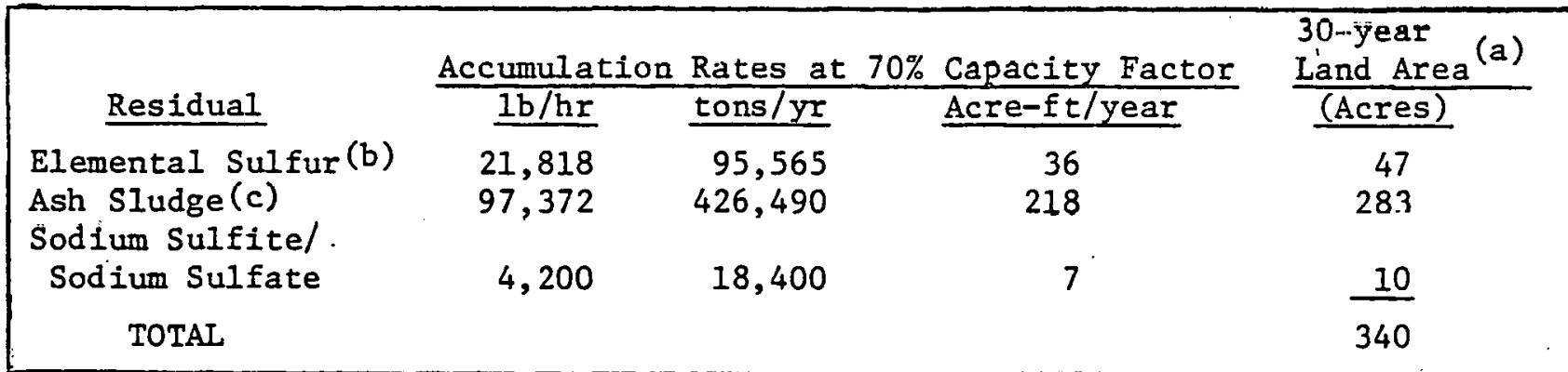

(a) Assumes $23 \mathrm{ft}$ disposal typical of current practices.

(b) Disposal density $=122 \mathrm{lb} / \mathrm{ft}^{3}$

(c) $80 \%$ ash, $20 \%$ water, density $=90 \mathrm{lb} / \mathrm{ft}^{3}$. Solids content is $88,8221 \mathrm{~b} / \mathrm{hr}$ from bottom ash, and $187 \mathrm{lb} / \mathrm{hr}$ from Wellman-Lord pretreatment. 


\subsection{LAND AND WATER USE}

In addition to the waste disposal areas required to support the reference high-sulfur coal facility, an additional 500 acres is assumed for the primary plant site. $(1,2)$ This area includes an exclusion area of roughly 200 acres which is comparable to the requirements of a nuclear power plant. As shown previously in the plot arrangement (Figure B-1), the site also has sufficient provision for optional doubling of capacity through the construction of a second unit.

Consumptive water use occurs as a result of: (1) the cooling tower evaporative lossses and blowdown, (2) general plant uses, and (3) process water from the Wellman-Lord $\mathrm{SO}_{2}$ removal system.' This system is the largest consumer of water. It requires 2 million gallons per hour for use in the venturi prescrubber and the absorber stage. Table 2-6 identifies various plant water uses.

Table 2-6. Water Use - 1250 MWe High-Sulfur Coal Generation

\begin{tabular}{|l|c|}
\hline USE & $10^{6}$ GALLONS / DAY \\
\hline Cooling Tower Evaporation & 17 \\
Cooling Tower Blowdown & 5 \\
Wellman-Lord SO 2 System & 48 \\
General Plant. Use & $\leq 1$ \\
& 70 \\
\hline
\end{tabular}

Sources: Adapted from References 1, 2, 4.

The primary sources of liquid effluents from a conventional coal combustion facility include: (1) the boiler and cooling tower blowdown streams and (2) leachate from the ash handling and waste disposal areas. Actual levels of residuals that reach surface water systems vary considerably from site to site. These levels of residuals are highly dependent on drainage characteristics and waste disposal practices. Groundwater systems can also be aftected either from percolation of rainwater through disposed wastes or from the movement of groundwater through the disposal area. Typical values of liquid effluents produced by the reference, high-sulfur coal facility operating at a $70 \%$ capacity are itemized in Table $2-7$. 
Table 2-7. Typical Wastewater Effluents--1250 MWe Coal Combustion Facility at $70 \%$ Capacity Factor

\begin{tabular}{|l|c|}
\hline POLLUTANTS & TONS /DAY \\
\hline BOD & 0.101 \\
COD & 9.832 \\
total suspended solids & 0.024 \\
total dissolved solids & 62.607 \\
aluminum & .022 \\
chronium & .001 \\
Hunferiuus metals & 7.940 \\
zinc & .004 \\
sulfates & 2.946 \\
nickel & .259 \\
nitrates: & .130 \\
ammonia & .004 \\
phosphorous & .012 \\
\hline
\end{tabular}

Source: Reference 15 


\subsection{CONSTRUCTION AND OPERATION CHARACTERISTICS}

\subsection{PERSONNEL REQUIREMENTS}

Barring unusual regulatory delays, the normal construction period for a large, coal-fired electric generation facility (of the type characterized here) would take a total of 7 years. This includes a low level of effort period of 2 years for: (1) site selection, (2) design, and (3) preparation. In addition, a 5-year period is needed for actual on site construction. During the onsite construction period, an estimated 9.3 million man-hours of direct craft labor would be required. Table $2-8$ details the 8 different labor types related to the above.

Table 2-8. Direct Labor Summary for. Construction Craft Labor for 1250 MWe Coal Facility

\begin{tabular}{|l|c|c|}
\hline \multicolumn{1}{|c|}{ CRAFT DESCRIPTION } & $\begin{array}{c}\text { SITE } \\
\text { LABOR HOURS }\end{array}$ & $\begin{array}{c}\text { PERCENT } \\
\text { OF HOURS }\end{array}$ \\
\hline Boiler Maker & 232,700 & 2.5 \\
Carpenter & 409,500 & 4.4 \\
Electrician & $1,544,900$ & 16.6 \\
Iron Worker & 967,900 & 10.4 \\
Laborers & 642,200 & 6.9 \\
Millwrights & 176,800 & 1.9 \\
Operating Engineers & 632,900 & 6.8 \\
Pipefitters & $2,475,500$ & 26.6 \\
Other Crafts & $2,224,300$ & 23.9 \\
\multicolumn{1}{|c|}{ TOTAL Direct Construction } & $9,306,700$ & 100.0 \\
\hline
\end{tabular}

Sources: References 16,17

The direct craft labor employment figures presented here do not include various inhouse utility and consultant man-hours. Both are considered indirect labor requirements by the utility for capital costing purposes. The magnitude of these indirect labor requirements, however, is somewhat less than the direct craft requirements. 
Normal operation of the facility would require a plant staff of 259 persons and over 518,000 man-hours/year, which is shown in Table 2-9.

Table 2-9. Direct Labor Summary for Construction and Operation of Reference 1250 MWe Coal Facility

\begin{tabular}{|c|c|c|}
\hline OPERATIONAL PERSONNEL & $\begin{array}{l}\text { NUMBER OF } \\
\text { PERSONNEL }\end{array}$ & $\begin{array}{l}\text { THOUSANDS } \\
\text { MAN-HOURS } \\
\text { PER YEAR }\end{array}$ \\
\hline \multicolumn{3}{|l|}{ Plant Managers Office } \\
\hline Manager & 1 & 2 \\
\hline Assistant & 1 & 2 \\
\hline Environmental Control & 1 & 2 \\
\hline Pub1lc Relatlons & 1 & $\underline{2}$ \\
\hline Training & 1 & 2 \\
\hline Safety & 1 & 2 \\
\hline Administrative Services & 13 & 26 \\
\hline Health Services & 1 & 2 \\
\hline Security & 7 & $\underline{14}$ \\
\hline SUBTOTAL & 27 & 54 \\
\hline \multicolumn{3}{|l|}{ Operations } \\
\hline Supervision & 3 & 6 \\
\hline Shifts & 45 & 90 \\
\hline Fuel and Materials Handling & 12 & 24 \\
\hline Waste Systems & 15 & 30 \\
\hline SUBTUTAL & 75 & 150 \\
\hline \multicolumn{3}{|l|}{ Maintenance } \\
\hline Supervision & 8 & 16 \\
\hline Crafts & 95 & 190 \\
\hline Peak Maintenance Annualized" & $\underline{35}$ & 70 \\
\hline EUB'IUTAL & 138 & 276 \\
\hline \multirow{5}{*}{$\begin{array}{l}\text { Technical and Engineering } \\
\text { Waste } \\
\text { Radiochemical } \\
\text { Instrumentetion and control } \\
\text { Performance, Reports and } \\
\text { Technicians }\end{array}$} & & \\
\hline & 1 & 2 \\
\hline & 2 & 4 \\
\hline & 2 & 4 \\
\hline & 14 & $\underline{28}$ \\
\hline SUBTOTAL & 19 & 38 \\
\hline TOTAL & 259 & 518 \\
\hline
\end{tabular}

* 300 persons for 6 weeks $=1,800$ person weeks $\div 52$ weeks $/$ yr $=35$ persons annualized

Source: Reference 18 
Occasionally, additional maintenance staff would be required to complete major scheduled or unscheduled emergency repairs on the turbine system, boiler, flue gas desulfurization system, or other major plant components.

\subsection{OPERATING STATISTICS AND ANNUAL GENERATION}

Historical statistics on large, coal-fired electric generation facilities of this type indicate that the overall plant capacity factor would be approximately $70 \%$. (That is, the plant would produce $70 \%$ of the maximum possible kilowatt-hours it could generate if it were operated continuously at full capacity.).

Numerous parameters combine to produce this factor. Namely, these include: (1) plant down-time for scheduled maintenance, (2) plant forced outage rate due to unexpected component failure, and (3) the customer load profile (including inter-utility sales of electricity). The first two factors combine to determine plant availability, while the inclusion of customer demand results in the plant capacity factor.

Typically, a large coal-fired station (such as the type characterized here), would be placed early in the utillty's loading order. Thus, it would hardly be affected by the customer's demand, since it would serve to satisfy part of the minimum customer load. However, a factor of .97 has been applied to the calculated plant availability to simulate a small reduction in plant operation because there is inadequate customer demand.

Scheduled maintenance for large coal facilities with flue gas desulfurization systems vary from 4 to 8 weeks per year, and forced outage rates range from 10 to $15 \% .(19,20)$ Here, the larger or more conservative values have been selected for the reference facility. Thus, plant availability is determined by:

Plant Availability $=\frac{52-8}{52} \times(1-.15) \times 100 \%=72 \%$

Adjusting for customer demand reduction results in:

Capacity Factor $=(72 \%)(.97)=70 \%$

At this capacity factor, reference 1250 MWe high-sulfur coal facility would generate $7.665 \times 10^{6}$ kilowatt-hours/year. 


\subsection{COST CHARACTERIZATION}

The Energy Economic Data Base (EEDB) report prepared for DOE by United Engineers and Constructors details the base capital costs estimated for the 1250 MWe reference, high-sulfur coal generation facility. Direct and indirect capital costs presented in the EEDB are on a consistent January 1, 1978 dollar basis. They are the identical 1232 Mwe United Engineers' plant design which provided the basis or starting point for the reference system characterization developed in the previous sections. $(1,2)$

\subsection{DIRECT CAPITAL COSTS}

The EEDB costs have been appropriately adjusted to reflect major design changes and increased power levels incorporated into the 1250 MWe reference, high-sulfur coal system design. Specifically, the major design modifications that affect the reference system's capital cost (as compared to the 1232 MW United Engineers' design) include:

- A $5.9 \%$ increase in the boiler steam supply, steam generator, forced air and pulverizer air drafts, ash and dust, and fuel handling system capacities

- Replacement of the conventional lime $\mathrm{SO}_{2}$ removal system processing only $88 \%$ of the flue gases with an advanced Wellman-Lord scrubber system to process $100 \%$ of the flue gas at a collection efficiency of $90 \%$ and elemental sulfur production from the process byproduct stream

- Installation of an in-stack steam-to-flue heat exchanger for reheating stack gas from $125^{\circ} \mathrm{F}$ to $175^{\circ} \mathrm{F}$

- A $4.3 \%$ increase in the turbine generator gross output to compensate for additional auxiliary electrical loads not considered in the UEC design, and to provide for the increased net capacity

- A $1.8 \%$ reduction in the condenser and cooling tower heat rejection sys rem

Base direct capital cost includes the costs of all materials, components, structures, and associated direct craft labor necessary to construct the reference facility at the plant site. Delivered costs for components, structures and materials are used. Base indirect costs include site temporary construction facilities, payroll insurance and taxes, and other construction services, such as home and field office expenses, field job supervision and 
engineering services. Specifically excluded from the base construction cost estimate are several items that are sensitive to the particular policies and preferences of the individual utility and to the specific plant site. Prevailing economic factors are being considered as follows:

- Owner's Costs - Consultants, Site Selection, etc.

- Federal, State and Local Fees, Permits, and Taxes

- Interest on Capital Construction Funds

- Price Escalation during Construction

- Contingency Funds

- Owner's Discretionary Items

- Switchyard and Transmission Costs

- Waste Disposal Costs

- Spare Parts

- Initial Fuel Supplies

We determined the 1250 . MWe reference, high-sulfur coal system costs by reviewing the detailed cost estimates made in the EEDB for the 1232 MWe United Engineers' design at the "3-digit" subaccount level and then adjusting the costs.

The capacity-ratio exponent estimating technique was used to make incremental cost estimate modifications. The technique uses the following equation to adjust component costs for small to moderate change component capacity:

Cost of Component $B=$ Cost of Component $A \times\left(\frac{\text { Capacity of } B}{\text { Capacity of } A}\right)^{\alpha}$ where component $A$ and Component $B$ are of similar design and performance, differing only in size or capacity, and where $\alpha$ is given by the following:

Account

20

21

22

23

24
Description

Land and Land Rights

Structures and Improvements

Boiler Plant Equipment

Turbine Plant Equipment

Eléctrlc Plant Equlpment

Miscellaneous Plant Equipment

Condenser Heat Rejection System
Cost Estimating Exponent ( $\alpha$ )

Not Applicable

.20

.85

.70

.20

.40

.50 
The costs of two major components not originally included in the United Engineers' design were estimated by other means or by using other sources of data. The in-stack heat exchanger to reheat the flue gases exiting from the Wellman-Lord scrubber at $125^{\circ} \mathrm{F}$ to $175^{\circ} \mathrm{F}$ was estimated based on cost estimates of similar equipment using TVS's SHAWNEE computer code. (27) Equipment and materials costs for an in-stack heater capable of heating $5.6 \times 10^{6} 1 \mathrm{~b} / \mathrm{hr}$ of flue gas from $125^{\circ} \mathrm{F}$ to $175^{\circ} \mathrm{F}$ have been estimated to be $\$ 1,035,600$ in 1978 dollars. This cost was adjusted to the reference system design having a flue gas flow rate of $13.0 \times 10^{6} \mathrm{lb} / \mathrm{hr}$ by applying a $0.70 *$ cost estimatiug expunent. Thus, equipment and materials costs for the reference system in-stark heater are estimated at $\$ 1,867,400$. Craft labor requirements estimated from the TVA program were increased in proportion to the equipment and materials costs. This was an estimate of the labor requirements for the reference system in-stack heater. Craft labor requirements were thus estimated to be 5,640 man-hours.

The Wellman-Lord flue gas desulfurization system also differs substantially from the wet lime scrubber assumed in the United Engineers' design. For this system, costs were estimated from a recent Environmental Protection Agency (EPA) publication (4) which estimates the total capital investment (equipment, , materials, labor, and working capital) for a $500 \mathrm{MW}$ and a 1000 MW power plant burning $3.5 \%$ sulfur coal at $\$ 42.39$ and $\$ 64.20$ millinn, respectively. Costs of the Wellman-Lord system for the reference 1250 MWe facility (burning 3.2\% sulfur coal) were estimated by removing $20 \%$ of the stated capital investment as working capital data to determine the equipment, materials, and labor costs for a $1250 \mathrm{MW}$ installation. That is:

Capital Cost for EPA $500 \mathrm{MW}$ Installation: $\$ 42.39 \mathrm{M} \times 0.80=\$ 33.91 \mathrm{M}$ Capital Cost for EPA $1000 \mathrm{MW}$ Installation: $\$ 64.20 \mathrm{M} \times 0.80=\$ 51.36 \mathrm{M}$

$$
\begin{aligned}
& \text { Implied Power Exponent } \alpha=\frac{\ln \left(\frac{51.36}{33.91}\right)}{\ln \left(\frac{1000}{500}\right)}=0.60 \\
& \text { Cost for } 1250 \mathrm{MWe} \text { Installation }=\$ 51.36 \mathrm{M}\left(\frac{1250}{1000}\right)^{0.60}=\$ 58.72 \mathrm{M}
\end{aligned}
$$

*The cost estimating exponent was assumed to be similar to that applicable to turbine plant equipment account which includes numerous heat exchangers. 
This figure compares with an estimated cost of $\$ 55.68$ million for the wet lime $\mathrm{SO}_{2}$ removal equipment associated with the United Engineers! 1232 MWe design. Direct. equipment and materials costs are estimated by assuming a direct labor requirement equal to that of the United Engineers' design for $\mathrm{SO}_{2}$ equipment installation, or $\$ 19.80$ million. Thus, the equipment and materials cost for the Wellman-Lord $\mathrm{SO}_{2}$ removal system is estimated at $\$ 38.82$ million.

Table 2-10 shows the original EEDB (United Engineers) cost estimate by "2-digit" accounts. Also shown are the applicable cost estimating factors and the resulting 1250 MWe reference system cost estimates for plant equipment and materials. Costs for land and land rights (Account 20) would not vary measurably over the capacity ranges considered here. Thus, the land costs shown assume a 500-acre site valued at $\$ 4,480$ per acre. Land requirements for waste disposal are charged to operation and maintenance costs.

Direct craft labor costs for the 1232 MWe United Engineers facility are estimated from approximately 8,920,400 man-hours at a craft-averaged cost of \$13.25 per man-hour. Labor costs for the reference system were estimated by first adding the labor requirements for installation of the in-stack heater to that of the United Engineers' facility. Man-hours and corresponding labor costs were then assumed to be proportional to the equipment and materials costs. (17). Resultant direct craft man-hours and costs are thus estimated to total 9,306,700 million man-hours and slightly more than $\$ 123.3$ million. 
Table 2-10. Estimated Direct Capital Costs for 1250 MWe Coal Combustion Reference System (January 1, 1978 Dollars)

\begin{tabular}{|c|c|c|c|c|}
\hline Account & Description & $\begin{array}{l}1232 \text { MWe EEDB }(a) \\
\text { Cost }(\$ 1000)\end{array}$ & CEM $^{(b)}$ & $\begin{array}{l}1250 \mathrm{MWe} \\
\text { Reference System } \\
\text { Cost }(\$ 1000)\end{array}$ \\
\hline 20 & Land \& Land Rights (c) & 2,240 & 1.000 & 2,240 \\
\hline 21 & $\begin{array}{l}\text { Structures \& Improve- } \\
\text { ments }\end{array}$ & 35,389 & $1.043^{0.20}$ & 35,688 \\
\hline \multirow[t]{4}{*}{22} & Boiler Plant Equipment & & & \\
\hline & $\begin{array}{l}\text { Total Except } \mathrm{SO}_{2} \\
\text { Removal }\end{array}$ & 99,690 & $1.059^{0.85}$ & 104,668 \\
\hline & $\begin{array}{l}\mathrm{SO}_{2} \text { Removal/Wellman- } \\
\text { L.nrd }\end{array}$ & 35,780 & (d) & 38,820 \\
\hline & In-S tack Heater & (e) & (e) & 1,867 \\
\hline 23 & $\begin{array}{l}\text { Turbine Plant- Equip- } \\
\text { ment }\end{array}$ & 102,929 & $1.043^{0.70}$ & 106,008 \\
\hline 24 & $\begin{array}{l}\text { Electric Plant } \\
\text { Equipment }\end{array}$ & 20,202 & $1.043^{0.20}$ & 20,373 \\
\hline 25 & $\begin{array}{l}\text { Miscellaneous Plant } \\
\text { Equipment }\end{array}$ & 7,126 & $1.043^{0.40}$ & 7,247 \\
\hline \multirow[t]{4}{*}{26} & $\begin{array}{l}\text { Cundensace Héat } \\
\text { Rejection System }\end{array}$ & 11,961 & $0.982^{0.50}$ & 11,853 \\
\hline & $\begin{array}{l}\text { Total Direct } \\
\text { Equipment \& } \\
\text { Materials Cost }\end{array}$ & 315,317 & & 328,764 \\
\hline & Site Labor Costs & 118,157 & (f) & 123,314 \\
\hline & $\begin{array}{l}\text { Total Direct Base } \\
\text { Construction Costs }\end{array}$ & 433,474 & & 452,078 \\
\hline
\end{tabular}

(d) EEDB, Energy Economic Data Base Source: Adapted from Reference 21

(b) $\mathrm{CEM}=$ Cost Estimating Multiplier, see tert: for discuesion

(c) Land and Land Rights for 500 acre main plant site at $\$ 4480 / a c r e$; waste disposal land allocated to operation and maintenance costs

(d) See text for discussion of cnst estimating relatiunships for Reference System Wellman-Lord $\mathrm{SO}_{2}$ Removal System

(e) Item not included in original EEDB design, see text for discussion

(f) Labor requirement for In-stack heater is added to EEDB estimate, then the total is escalated in proportion to Direct Equipment and Materials Costs 


\subsection{INDIRECT CAPITAL COSTS}

Indirect capital costs assoclated with the construction of large coal combustion power plants are relatively insensitive to the plant capacities used in the EEDB and as the reference system described here. Thus, except for payroll related expenses, indirect capital costs for the 1250 MWe reference system have been taken to be the same as those for the EEDB 1232 MWe plant. Construction payroll related expenses include payroll insurance and taxes as well as field job supervision costs, which were assumed to be proportional. to the reference system direct field labor costs. This assumption adds $\$ 839,000$ to the Construction Services' account ( $\$ 91$ ) and $\$ 607,000$ to the Field Office Engineering and Services' account (非3) over those costs estimated in the EEDB.

Indirect capital costs summarized in Table 2-11 at the "2-digit" account level, total $\$ 90,706,000$, or about $20 \%$ of the direct capital cost estimated for the reference system.

Table 2-11. Estimated Indirect Capital Costs for 1250 MWe Coal Combustion Reference System (January 1, 1978 Dollars)

\begin{tabular}{|c|c|c|}
\hline Account & Description & $\begin{array}{l}1250 \text { MWe Reference } \\
\text { System Cost }(\$ 1000)\end{array}$ \\
\hline 91 & Construction Services & . $\quad 55,469$ \\
\hline 92 & $\begin{array}{l}\text { Ilome Office Englneerlng } \\
\text { and Services }\end{array}$ & 18,790 \\
\hline \multirow[t]{2}{*}{93} & $\begin{array}{l}\text { Field Office Engineering } \\
\text { and Services }\end{array}$ & 16,447 \\
\hline & TOTAL INDIRECT & 90,706 \\
\hline
\end{tabular}

Source: Adapted from Reference 21 


\subsection{OPERATION AND MAINTENANCE COSTS}

Annual operation and maintenance (O\&M) costs for the 1250 MWe reference high-sulfur coal facility have been estimated. Based on cost estimating relationships in a recent Oak Ridge National Laboratory (ORNL) document entitled "A Procedure for Estimating Nonfuel Operation and Maintenance Costs for Large Steam Electric Power Plants," (18). the data is available in the EEDB. (22) These cost estimating relationships were adjusted for characteristics unique to the reference design considered here and were supplemented with EPA data on WellmanLord flue gas desulfurization O\&M costs. (23)

Generally, O\&M costs may be considered to be composed of six cost categories. They may be either fixed costs (not dependent on annual generation) or variable costs which are proportional to generation level. The six cost categories considered here include: Plant Staffing, Maintenance Materials, Plant Supplies and Expenses, Environmental. Controls, Interim Replacements, and Administrative and General Expenses.

Plant staffing costs are based on the 259-person plant staff described earlier and assumes a cost of $\$ 22,000$ per person per year. Maintenance materials have been found to average $82 \%$ of the maintenance staff costs ( 138 persons; for large coal generation plants with flue gas desulfurization; $62 \%$ for fixed expenses and $20 \%$ representing a maximum level variable expense at a plant capacity factor of $80 \%$. Fixed supplies and expenses have been estimated In the ORNL report to be $\$ 1.4$ million/year with a variable component of $0.05 \mathrm{mills} / \mathrm{kWh}$. Administrative, overhead, and utility home office general expenses associated with the reference facility are estimated by ORNL to be 10\% of: (1) the staff costs, (2) the fixed components of the materials, and (3) the supplies costs. (18)

Operation and maintenance costs for environmental controls are based primarily on the ash, elemental sulfur, and dry sodium sulfite/sulfate disposal rates costed at $\$ 10 /$ ton for ash sludge and $\$ 4 /$ ton for the others, assuming remote site disposal. A disposal site land area of 11.3 acres/year at $\$ 4,480 /$ acre has also been included in the estimated environmental controls O\&M costs. Based on EPA data, feed materials, such as 1ime, sodium carbonate, catalyst, antioxidant and natural gas, are required for operation of the WellmanLord flue gas desulfurization system and the processing of its byproduct stream into elemental sulfur. 
Annual costs for interim replacements of major capital items have been added to the O\&M costs estimated by ORNL and in the EEDB. These were estimated to be $30 \%$ of the direct and indirect plant capital costs over its 30-year lifetime. A sinking fund annuity at $4 \%$ real interest was assumed to accrue $30 \%$ of the direct and indirect capital costs for interim replacements over the plant's lifetime. At this rate, $1.78 \%$ of $30 \%$ of the total plant capital costs ( $0.53 \%$ of total plant cost) is changed to $0 \& M$ each year.

Table. 2-12 details the annual O\&M costs estimated for the reference highsulfur coal system. At the $70 \%$ capacity factor assumed for the reference coal system, annual O\&M costs total $\$ 23.5$ million or $3.06 \mathrm{mills} / \mathrm{kWh} ; 1.66 \mathrm{mills} / \mathrm{kWh}$ are fixed costs while $1.40 \mathrm{mills} / \mathrm{kWh}$ are variable with plant load factor.

These O\&M costs compare to an estimated $3.4 \mathrm{mills} / \mathrm{kWh}$ for an identical system using wet limestone scrubbers. The difference, 0.34 million per year, is a result of reduced disposal costs and disposal site land requirements achievable with the advanced Wellman-Lord sulfur removal system and $\mathrm{SO}_{2}$ to elemental sulfur production.

Several of the foregoing cost estimating relationships are considered high. For example, interim replacements totaling $30 \%$ of the plant's direct and indirect costs is about two to three times that which would be expected for a facility of this type. $(24,25)$ Also, if it were assumed that the elemental sulfur were marketed at its long term equilibrium market price of $\$ 50 /$ ton, ${ }^{(26)}$ sulfur disposal handling costs of $\$ 382,000 /$ year, and associated land costs of $\$ 7500 /$ year would be avoided. A credlt of $\$ 4,778,250 /$ year would be received. These modifications would reduce the reference plant's annual O\&M cost to $\$ 18,297,250 /$ year of $3.29 \mathrm{mills} / \mathrm{kWh}$, a $22 \%$ reduction from the O\&M cost used here. 
Table 2-12. Annual Operation and Maintenance Costs for 1250 MWe Reference High-Sulfur Coal Facility at $70 \%$ Capacity Factor

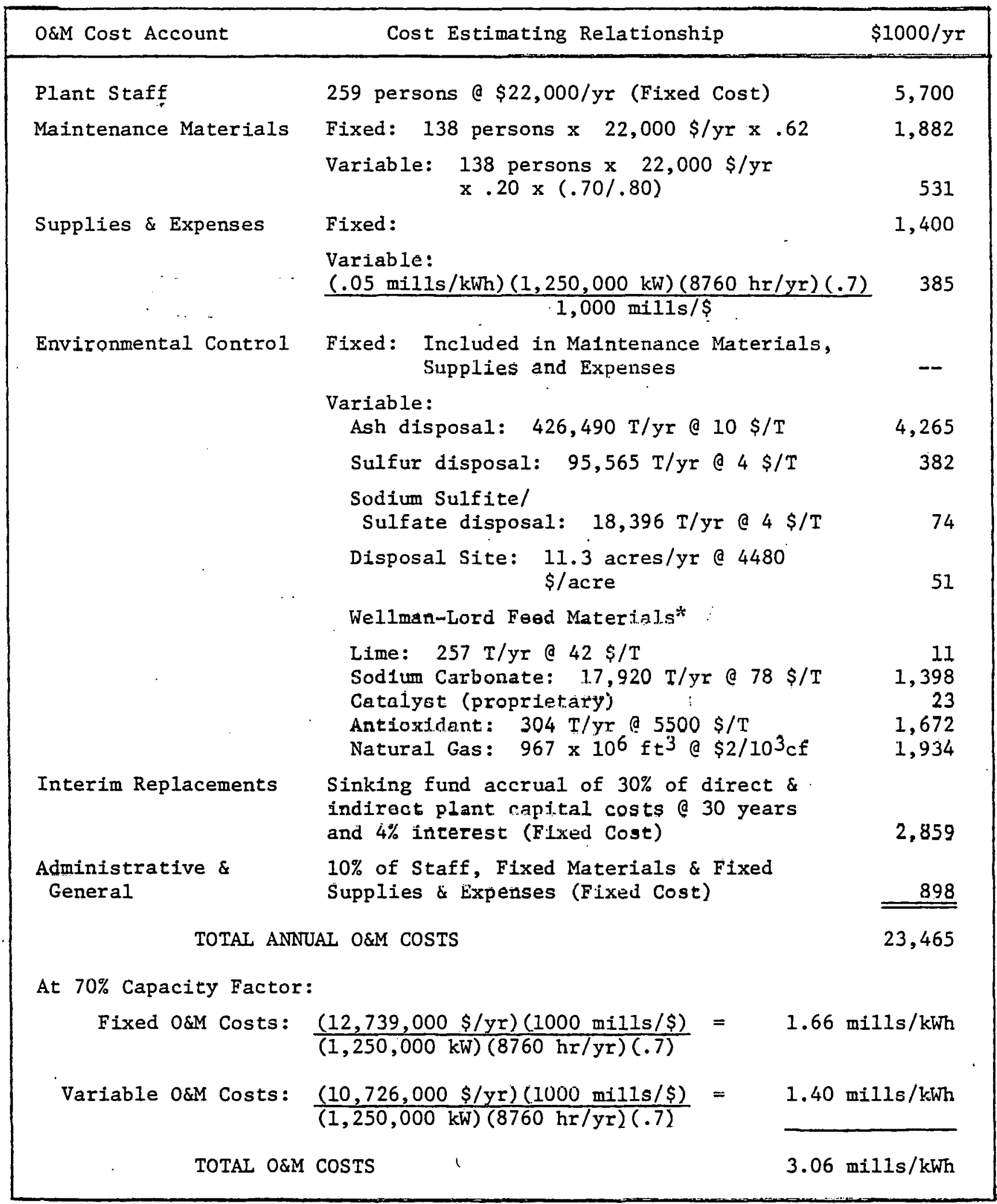

*Based on EPA data, Reference 4

Sources: Refs. 4, 18, 22, 23 
REFERENCES - CONVENTIONAL COAL

1. United Engineers and Constructors, Commercial Electric Power Cost Studies - Capital Cost: High and Low Sulfur Coal Plants - 1200 MWe, Prepared for the U.S. Nuclear Regulatory Commission and the U.S. Department of Energy. NUREG-0243, CO0-2477-7, Vols. 1 and 2. June 1977.

2. United Engineers and Constructors, Satellite Power System and Alternative Technology Characterization. UE\&C-ANL-790831. August 1979.

3. Environmental Reporter. June 1, 1979. pp. 143-144.

4. Summary Report Sulfur Oxides Control Technology Series: Flue Gas Desulfurization Wellman-Lord Process. USEPA, Industrial Environmental Research Laboratory. EPA 625/8-79-001. Research Triangle Park, N.C. February 1979.

5. Reference 2. pp. 2.2-1.

6. Shelton, J.E., Sulfur. Prepared by the Bureau of Mines, Mineral Commodity Profiles, pp. 22-24. 1979.

7. Adapted from References 1 and 2 .

8. Personal Communication. P. Farber. Argonne National Laboratory. January 1980 .

9. United Engineers and Constructors, Commercial Electric Power Cost Studies - Capital Cost Pressurized Water Reactor Plant. NUREG-0241, COG-2477-5, Vo. 2 of 2. Prepared for the U.S. Nuclear Regulatory Commission and U.S. Department of Energy. May 1977.

10. Hudson, John Wiley \& Sons (Pub.) The Engineers' Manual, Second Edition. August 1945 .

11. Adapted from Reference 4, p. 25.

12. Rrown, D.H., Conccptual Design aud Implementation Assessment of a Utility Steam Plant with Conventional Furnace and Wet Lime Gas Scrubbers. Energy Conversion Alternatives Study (ECAS). General Electric Company for NASA, CR-134950. December 1976.

13. Tennessee Valley Authority. Utility Boiler Design/Cost Comparison: Fluidized Bed Combustion versus Flue Gas Desulfurization. Prepared for the USFPA, EPA 600/7-77-126. November 1977.

14. Personal Communication. K. Wilzbach. Argonne National Laboratory. February 1980.

15. Environmental Data Energy Technology Characterization - Coal. DOE/EV0061/3, Vo1. 3. U.S. Department of Energy, pp. 5-8. January 1980. 
16. Reference 2, P. 1.2-8.

17. Persona1 Communication. E. Ziegler. United Engineers and Constructors, Philadelphia, PA. February 1980.

18. Myers, M. L. and L. C. Fuller. A Procedure for Estimating Nonfuel Operation and Maintenance Costs for Large Steam-Electric Power Plants. Oak Ridge National Laboratory, ORNL/TM-6467. Oak Ridge, TN. January 1979. p. 25.

19. Reference 18, p. 12 .

20. Personal Communication. W. A. Buehr1ng. Argonne National Laboratory. January 1980.

21. United Engineers and Constructors. Final Report and Initial Update of Lhe Energy Economic Data Base (EEDR) Prngram Phase I, UE\&C-DOE-790930, C00-4954-1, Vol. I of III, Table 5-10, p. 5-36. Prepared for the U.S. Department of Energy, Philadelphia, PA. December 1979.

22. Reference 21, Table 7-8, p. 7-14.

23. Reference 4, pp. 24-29.

24. Reference 21 , Vol. II of III, pp. c-1-13. (Cites a value of $0.35 \%$ per year, $\sim 10 \%$ over 30 year lifetime).

25. Personal Communicat1on. J. Whysong, Electrie Utility Consultant. Chicago, IL. February 1980.

26. Reference 6, p. 17 .

27. Personal Communication. C. D. Livengood. Argonne National Laboratory. February 1980. Based on Tennessee Valley Authority's SHAWNEE computer code. 
SECTION 3. LIGHT WATER REACTOR WITH IMPROVED FUEL UTILIZATION 


\section{LIGHT WATER REACTOR WITH IMPROVED FUEL UTILIZATION}

\subsection{INTRODUCTION}

The 1250 MWe light water reactor (LWR) facillty characterization provided In this section was written and based primarily on "Satellite Power System and Alternate Technology Characterization" prepared by United Engineers and Constructors, Inc., August 1979, UEC-ANL-790831. The cost data also provided in this characterization is based on NUREG-0241, "Capital Cost: Pressurized Water Reactor Plant," prepared by United Engineers and Constructors, Inc. In both cases, the reactor plant itself is based on the Westinghouse 3425 MWe reactor described in RESAR-35, and an inland nuclear site (Middletown), and a UEC balance of plant design with mechanical draft cooling towers.

The description in this report is structured with the purpose of comparing one technology with another, both projected to the year 2000 . In this respect, the technologies had to be made comparable with regard to electrical energy generation: $1250 \mathrm{MWe}$ was chosen as being representative of large bulk power generation facilities in the year 2000. The basic Westinghouse $3450 \mathrm{MWt}$ reactor plant was scaled up to $3800 \mathrm{MWt}$. The cost estimate is based on this plant as well as major equipment. While scaling does provide a valld general representation of the 1250 MWe plant, a more representative or meaningful characterization would have been obtained if the Westinghouse 3800 MWt unit (described in Resar-41) were used.

Fuel utilization in a nuclear plant is the subject of current RD\&D programs. The basic goal of these programs is to increase the burnup of the fuel and decrease the U-235. requirement on a per-unit-of-power generation basis. At the present time, nuclear fuel is being discharged from reactors after achleving an average burnup of 25,000 to 33,000 megawatt days per metric tonne of fuel (MWD/MT). NCw fuel deslgns are being tested at commercial nuclear facilities in the hopes of ultimately achieving a 50,000 MWD/MT burnup. For the purpose of this characterization, a maximum 50,000 MWD/MT burnup is assumed for the LWR In the year 2000 .

A 1250 MWe nuclear reactor is loaded with approximately 98 metric tonnes (MT) of fuel at beginning of life and will consume about 20 MT each refueling. 
Over the past 10 years, the basic designs of the nuclear facilities have changed dramatically. Size of the units has increased to about 1250 MWe ( $3800 \mathrm{MWt}$ ) and extensive safety systems have been incorporated. Between now and the year 2000, size is assumed not to increase beyond present standards because of safety concerns by the NRC. However, safety will continue to be a major driving force in the design modifications of nuclear factlities. Investigations of the Three Mile Island accident will produce design changes for safety reasons in the near-term. Through the year 2000, the continued striving for a "perfectly safe" form of nuclear energy will result in numerous design changes required by the regulatory agencles to enhanee anfety.

Pollution control equipment will continue to be required for power generation faclilicles. Fui a nuelear plant, better radinlogical control equipment will be developed and installed to minimize or eliminate entirely hazardous radionuclide emissions, In addition, pollutant abatement regulations are assumed to require no process stream discharges containing any pollutants. The only assumed exception to this basic assumption is the cooling tower blowdown. However, degradable biocides and corrosion inhibitors are assumed to be used in the cooling towers. Ice prevention is accomplished through temperature control.

The fuel cycle assumed for the LWR characterization is the once through, throw away fuel cycle. Spent fuel disposal is accomplished by the Federal Government in Federally owned disposal facilities (a geologic repository is assumed). Costs for spent fuel disposal are recovered by the Government through a charge levied on the user of the waste disposal facilities. Reprocessing is not allowed. 


\subsection{GENERAL PLANT CONFIGURATION}

The reference LWR described in this section is a single-unit pressurized water reactor of Westinghouse Electric Company design with a net plant capacity of 1250 MWe. The basic nuclear plant is modeled after the Westinghouse 3425 MWt unit as described in RESAR-35 and coupled to a balance-of-plant concept designed by United Engineers and Constructors (UEC) as described in their reports "Commercial Electric Power Cost Studles," and "Satellite Power System and Alternative Technology Characterization." The primary features of the UEC design are the Nuclear Steam Supply System (NSSS), the six flow tandem compound turbine generator with supporting power conversion cycle equipment and systems, and the station cooling system using three mechanical draft wet-cooling towers.

The overall desten of the unit was based on the 1icensing, design, construction, and operation criteria, standards, codes, and guidelines in effect about January 1 1976. The characterization represents the current state of technology in the late $1970^{\prime}$ 's but projected to the year 2000 . It must be realized that between the time the reference plant was designed and the year 2000, numerous changes will be made in the design requirements of the LWR levied by the various regulatory agencies. These design requirement changes will be derived from the lessons learned at Three Mile Island, some of which are known and can be quantified. However, many more design changes will be required through the year 2000 which cannot be quantifled nor anticipated at this time. Caution must be exercised then in the use of this design projected to the year 2000 .

Figure 3-1 shows the basic plot plant for a single 1250 MWe LWR facility. The predominant features include the containment structure, switchyard, three mechanical draft cooling towers, and the turbine building. The layout also includes provision for the addition of a second unit at some future date. Space requirements for these additional facilities are shown by the broken lines on Figure 3-1. 


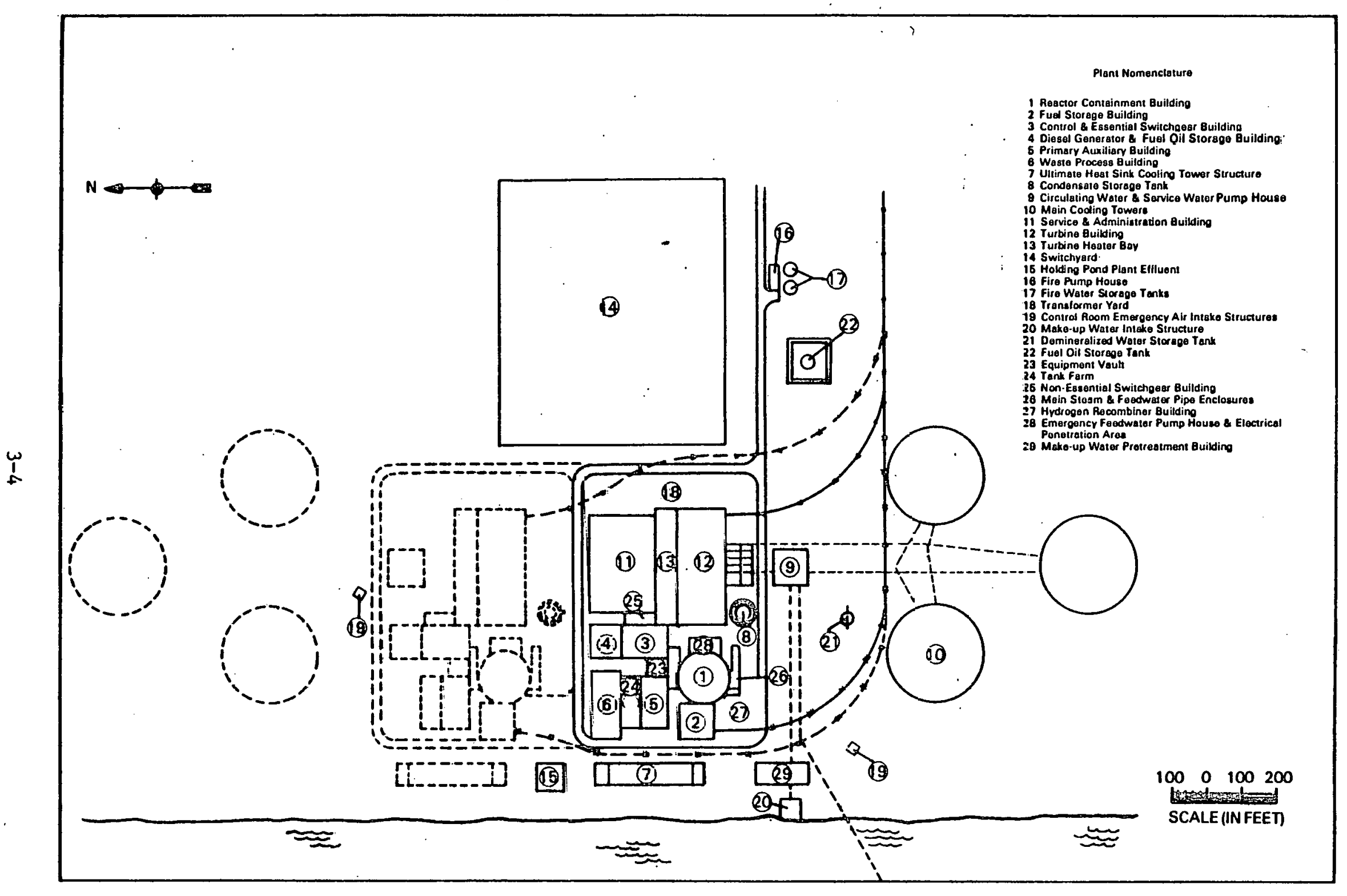

Figure 3-1:. Plot Plan 1250 MWe LWR Facility 
One of the more striking features of the nuclear reactor power station is the reactor containment bullding, a leak-tIght reinforced concrete cylindrical structure with a hemispherical dome based on a flat reinforced concrete foundation mat. The cylindrical portion of the building is approximately $140 \mathrm{ft}$ in diameter and the dome has an inside spherical radius of $70 \mathrm{ft}$. The inside height, from the foundation mat to the top of the dome, is $219 \mathrm{ft}$ and the minimum thickness of the dome structure is $2.5 \mathrm{ft}$. The turbine and generating equipment are housed in a separate building immediately adjacent to the reactor containment building. A primary auxiliary building having structural requirements similar to the reactor containment adjoins the reactor containment building. The building contains (in addition to the primary component cooling systems) most of the engineered safety features designed to protect the reactor core. This includes the low-pressure injection system, the containment core spray and emergency core cooling systems. A waste processing building houses liquid and gas waste-processing (as well as other systems which may have any radloactivity assoclated with them). The control systems for the entire station are located in a separate control building. The building has structural requirements simflar to that of the main containment. The electrical generating portion of the plant is similar to that associated with fossil fuels systems. It consists of the turbine and the generator connected with it, the main condenser, and the associated feedwater equipment.

The balance of the reactor plant systems includes the boron recycle system, radwaste system, service waste systems, containment spray, combustible gas controls, fuel handling, fuel storage, reactor makeup water system, the primary component cooling water system, and the air cleanup system. The balance of the conventional portion of the plant includes the usual transformer, switchgear and switchyard components, and the connection to the distribution lines. The main condenser heat rejection system includes makeup water intake and discharge structures, circulating water pumphouse, makeup water pretreatment facllities, and three mechanical draft wet-cooling towers. 


\subsection{THERMODYNAMIC CYCLE CHARACTERISTICS ${ }^{(1)}$}

The NSSS consists of a light-water-moderated nuclear reactor having a reactor core containing 1ow enriched uranium oxide fuel, approximately $4.0 \%$ $\mathrm{U}-235$, in approximately 193 fuel assemblies. The core is refueled by replacing approximately one-third of the total set of fuel elements at roughly one year intervals. The spent fuel is stored onsite in a speclal fuel handling building. This building is also a repository for fresh fuel prior to its insertion in the core.

The NSSS produces approximately $3760 \mathrm{MWt}$ at nominal full power. The power generation system consists of the reactor core and vessel, its associated pressurizer, and four primary reactor cuvlant $100 \mathrm{ps}$ and four eteam generators, Primary coolant (water) is heated by the nuclear reaction taking place in the core. This hot water is then passed through the steam generators (u-tube heat exchangers) where water on the secondary side of the heat exchanger is heated to produce steam. Water on the primary side of the steam generator is returned to the core to be reheated. Steam produced on the secondary side of the steam generator passes through the turbine generator power conversion system. The turbine generators, at nominal rated power, produce 1250 MWe. The condensate from the turbine is returned by the steam generator feedwater pumps. The reactor is equipped with residual heat removal systems and a number of engineered safeguards to permit shutdown and heat removal under all credible accident conditions.

\subsection{REACTOR CORE AND VESSEL}

The reactor core is composed of the fuel assemblies containing the fissionable uranium dioxide material contained in zircaloy-4 tubes. The tubes are bundled together forming fuel assemblies which are in turn placed together inside the reactor veșsel (cylindrical in thayt) to form the corc. Pressur= ized primary coolant (water with borlc acid added for reactor control) is circulated up through the core and heated by the nuclear reaction.

Control rods and acid in the primary coolant provide control of the nuclear reaction. The control rods and boric acid absorbs neutrons produced by the reaction and necessary for its maintenance. The control rods are used primarily for rapld reactor control (power changes, reactor rap1d shutdowns, 
etc.) while the boric acid is used primarily to control slow changes in the reactor (fuel depletion and Xenor transients). Table 3-1 shows the various characteristics of the reactor core and fuel.

Table 3-1. Key Parameters, Nuclear Steam Supply System 1250 MWe Pressurized Water Reactor Plant

\begin{tabular}{|c|c|}
\hline Parameters & Operating Description \\
\hline 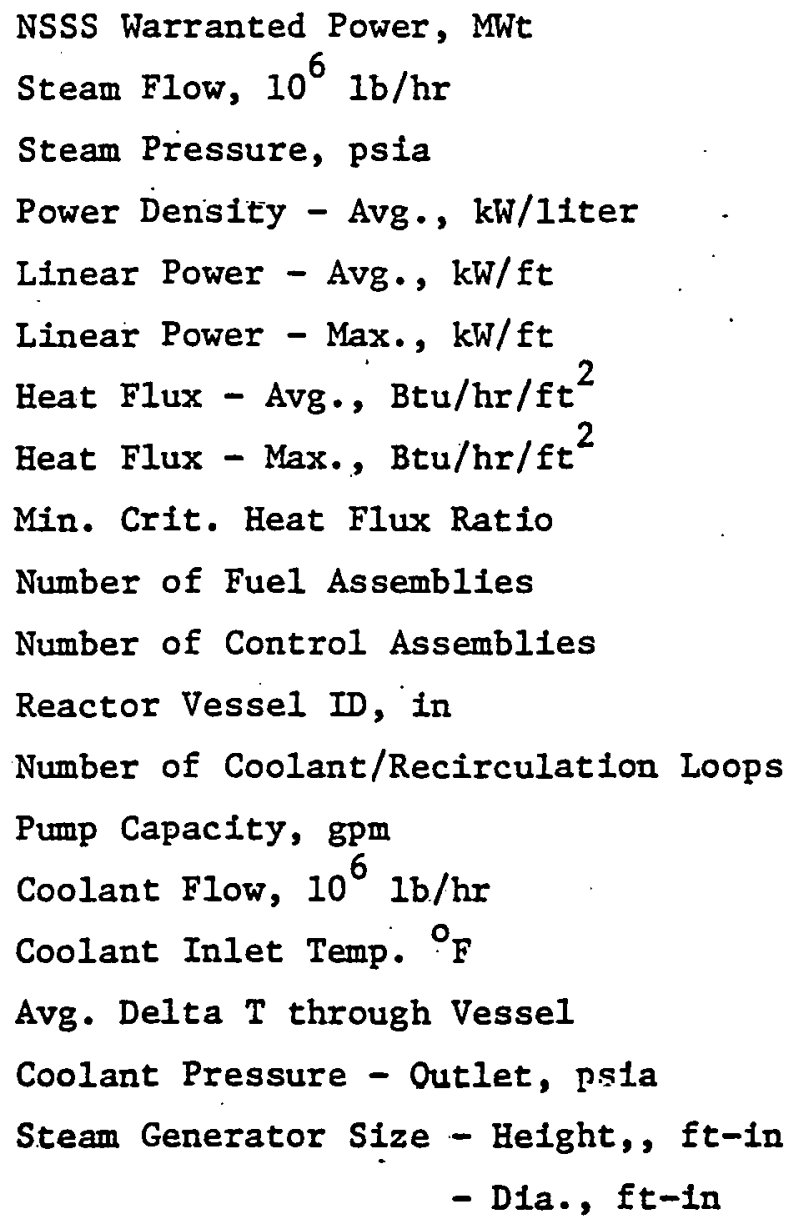 & $\begin{array}{c}3,750 \\
16.62 \\
1,100 \\
104 \\
5.4 \\
12.6 \\
189,800 \\
474,500 \\
1.3 \\
193 \\
65 \\
173 \\
4 \\
103,635 \\
165.2 \\
563.8 \\
61.1 \\
2,250 \\
67-8 \\
14-8\end{array}$ \\
\hline
\end{tabular}




\subsection{REACTOR PLANT EQUIPMENT}

The reactor plant design incorporates four parallel primary loops circulating reactor coolant through the reactor core and the four steam generators. Four primary coolant pumps each circulate the coolant through the reactor and steam generators at an average flow rate of $165.4 \times 10^{6} \mathrm{lb} / \mathrm{hr}$, with a reactor inlet temperature of $563.8^{\circ} \mathrm{F}$ and an average temperature rise of $61.1^{\circ} \mathrm{F}$. The nominal coolant pressure is 2250 psia. The high pressure is maintained in the primary system by a pressurizer to prevent boiling in the core.

The steam generation system conststs of four water-to-water/steam oncethrough steam generators (one for each of the primary coolant loops). The steam generators are the vert1cal shell and U-tube evaporator type with integral moisture separation equipment. The reactor coolant is on the tube side. Steam is produced at 1100 psia and $556.3^{\circ} \mathrm{F}$. The feedwater temperature is $440^{\circ} \mathrm{F}$. The total steam design flow. rate is $16.62 \times 10^{6} \mathrm{lb} / \mathrm{hr}$.

In addition to the primary heat transfer tystems, the reactor operation is supported by a wide variety of supporting systems including the safety systems used to mitigate the consequences of reactor accidents, radioactive waste processing and handling systems, and varlous chemical makeup and sampling systems.

\subsection{TURBINE GENERATOR CONFIGURAIION}

The turbine configuration is a tandem compound, six flow machine with 43 Inch last stage blades, designed and operated at $1800 \mathrm{rpm}$. Inlet steam conditions at the HP throttle valves are $975 \mathrm{psia}$ and $544^{\circ} \mathrm{F}$. No superheat is provided by this reactor plant design so the inlet steam is at saturation.

The generator is rated at 1482 MVA at a $0.9 \mathrm{PF}$. The generator output is $25,000 \mathrm{~V}, 3$ phase, $60 \mathrm{~Hz}$ and delivers 1309 MWe gross.

The steam flow configuration through the turbines begins with high pressure steam entering the high pressure turbine. As the steam passes through the EP and LP turbines and expands, the steam imparts about $1.37 \times 10^{10} \mathrm{Btu} /$ hr $(1,329,985 \mathrm{~kW})$ to the turbine shaft. Table 3-2 shows key plant parameters. 
Table 3-2. Key Plant Parameters, Steam and Power Conversion System 1250 MWe Pressurized Water Reactor Plant

\begin{tabular}{|l|c|}
\hline \multicolumn{1}{|c|}{ Parameter } & Operating Description \\
\hline Turbine Output, MWe & 1,309 \\
Auxiliary Power, MWe & 59 \\
Net Power to Transformer, MWe & 1,250 \\
Generator Rating, MVA & 1,482 \\
Net Station Steam Rate, 1b/kWh & 13.3 \\
Net Stat1on Heat Rate, Btu/kWh & 10,224 \\
Plant Efficiency \%. & 33.4 \\
Main Steam Flow at HP Turbine Inlet, 1b/hr & $.16,621,439$ \\
Main Steam Pressure at HP Turbine Inlet, psia & 975 \\
Main Steam Temperature at HP Turbine Inlet, ${ }^{\mathrm{F}}$ & 544 \\
\hline
\end{tabular}

\subsection{CONDENSER-HEAT REJECTION SYSTEM}

Three equalized single stage, two pass-surface condensers, with divided fabricated steel water boxes and shell, are provided. The condensers are designed to condense the low press turbine outlet steam and feedwater pump auxillary turbine drive exhaust steam. at 3.75 in Hga by dissipating the heat to three mechanical draft wet-cooling towers. Each condenser contains about $328,000 \mathrm{sq}$. ft. of condensing surface made up of 19,910 1-1/8 inch diameter, 20 BWG 90-10 CuNi tubes.

The three main mechanical draft wet-cooling towers are each sized for one-third of the requirements. Each tower is designed to cool 215,000 gpm of water from $118^{\circ} \mathrm{F}$ to $92^{\circ} \mathrm{F}$ when operating at a wet bulb temperature of $70^{\circ} \mathrm{F}$. Each tower employs a reinforced concrete-filled structure combined with components for water distribution, fill splash service, support system, drift eliminators, louvers, and fan deck. The fan deck provides a stable base for the 12 fan cylinders and mechanical equipment. Each fan is 33 . ft in dameter and operates in an $18 \mathrm{ft}$ high glass reinforced polyester velocity recovery fan stack. The hot water distribution system includes a circular flume distribution basin and metering orifice which uniformly distributes the hot water over the fill. 


\subsection{FEEDWATER HEATERS}

Feedwater flow from the condenser enters a series of six series reverse cascade feedwater heaters designed to achieve a final feedwater temperature of $440^{\circ} \mathrm{F}$ at $16.62 \times 10^{6} \mathrm{Ib} / \mathrm{hr}$. The first five stage heaters are low pressure. The final stage is designed for full steam generator pressure. Steam for the feedwater heaters is provided from the moisture separator and various extraction points throughout the steam cycle, and from other residual steam flows. A total of $6.07 \times 10^{9} \mathrm{Btu} / \mathrm{hr}$. is added to the feedwater before entering the boiler as shown in Figure 3-2. Small amounts of energy are contributed by the condensate and feed pumps primarily from pump thermal losses.

\subsection{GENERATOR LOSSES AND AUXILIARY ELECTRTC ENERGY USE}

The total power delivered to the turbine shaft is about $1,329,985 \mathrm{~kW}$. Various generator inefficlencies result in the loss of $21,147 \mathrm{~kW}$ or $1.60 \%$ of the shaft power as fixed and generation losses. Approximately $58,785 \mathrm{~kW}$ is required to support the plant operation (as shown in Table 3-3). This results in a net output of $1,240,053 \mathrm{~kW}$.

\section{Table 3-3. Auxiliary Power Requirements}

\begin{tabular}{|l|c|}
\hline \multicolumn{1}{|c|}{ Component } & Load in Rilowatts (kW) \\
\hline Main Coolant Fumps & 22,920 \\
Condensate Pumps & 2,045 \\
Heater Drain Pumps & 2,045 \\
Condensate Booster Pumps & 4,095 \\
Servife Watui Pumpe & 820 \\
Cooling Tower Fans & 4,425 \\
Make-up Water Pumps & 210 \\
Circulating Water Punps & 16,350 \\
TOTAL & 52,910 \\
Miscellaneous Small Pumps, Fans, & \\
Heaters & 3,295 \\
"Hotel" Load & 2,580 \\
TOTAL & 58,785 \\
\hline
\end{tabular}




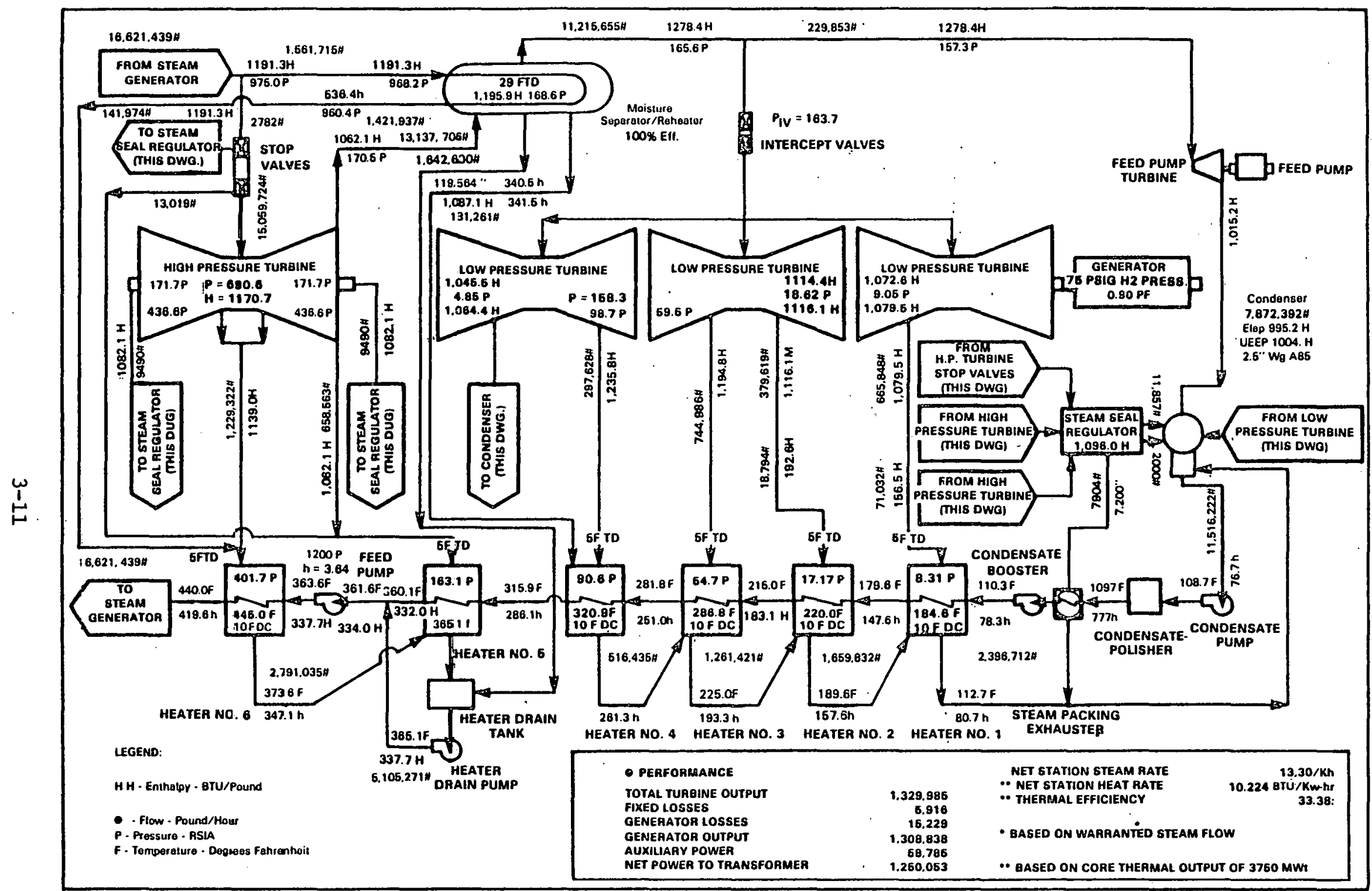

Figure 3-2. Light Water Reactor Facility Heat Balance 


\subsection{FUEL USE AND LOGISTICS}

The reference LWR facility uses $4.15 \%$ enriched uranium. (8) The Department of Energy provides enrichment services to the utility industry producing uranium hexafloride containing 4.15\% U-235. The UF 6 is then converted to $\mathrm{UO}_{2}$ and fabricated into fuel assemblies for use in the reactor. For the reference 1250 MWe net LWR, approximately $98,000 \mathrm{~kg}$ of fuel are loaded into the reactor.

The fuel is discharged from the reactor after it has achieved an average burnup of $50,000 \mathrm{MWD} / \mathrm{MT}$. (8) After discharge, it is placed in the spent fuel pool for temporary storage. During this temporary storage, the residual decay heat produced by fission product decay is removed by the fuel pool cooling system. Storage in this spent fuel pool could last for from one to five years at which time the spent fuel is shipped offsite to government owned and operated disposal facilities. The storage time on site will depend on waste acceptance criteria at the AFR or the repository.

The reactor does not discharge all of its fuel during refueling. Only about $1 / 5$ of the assemblies are replaced during each refueling, while the other $4 / 5$ are moved to different positions in the core. Refueling would take place about every 12 months at a $70 \%$ capacity factor. New fuel is shipped to the site and stored dry. 


\subsection{ENVIRONMENTAL CHARACTERISTICS}

Numerous reactor plant systems, even under normal conditions, become contaminated with radioactive elements. These elements can come from the fuel itself or from: (1) impurities in the fuel cladding, (2) activated wear products, or (3) other sources. Because several systems are contaminated, normal maintenance, operations, and leaks will lead to release of some of these elements.

The transport mechanisms for release of these radioactive elements are primarily through the building ventilation systems and processed liquid effluents. Areas which have the potential for contamination are ventilated through high efficiency particulate filters. These filters remove greater than 99.9 percent of the particles in the air which are larger than 0.3 microns. Potentially contaminated liquid effluents are monitored or processed to remove radioactive elements by filtration and ion exchange. In each case, not all of the radioactive elements can be prevented from entering the biosphere. Consequently, radioactive elements are emitted to the biosphere by the LWR. Tables 3-4 and 3-5 ifst the expected annual average radionuclide releases from the reference IWR. Additional releases resulting from other parts of the fuel cycle are discussed in the following section on the nuclear fuel cycle.

\subsection{SOLID WASTE}

Normal maintenance and operation of an LWR results in the generation of on-site solid and liquid wastes. Clothing, rags, laboratory equipment, monitoring equipment, tools, filters, etc., all can become contaminated and, if decontamination is not possible, should be discarded. Table 3-6 shows the average annual shipments of on-site generated waste. These wastes are categorized as low-level wastes and are sultable for disposal in licensed commerclal low-level waste burtal grounds.

Uncontaminated solid waste and refuse is also generated at the plant site and disposed of by conventional landfill offilte. 
Table 3-4. Expected Annual Average Release of Airbcrne Radionuclides

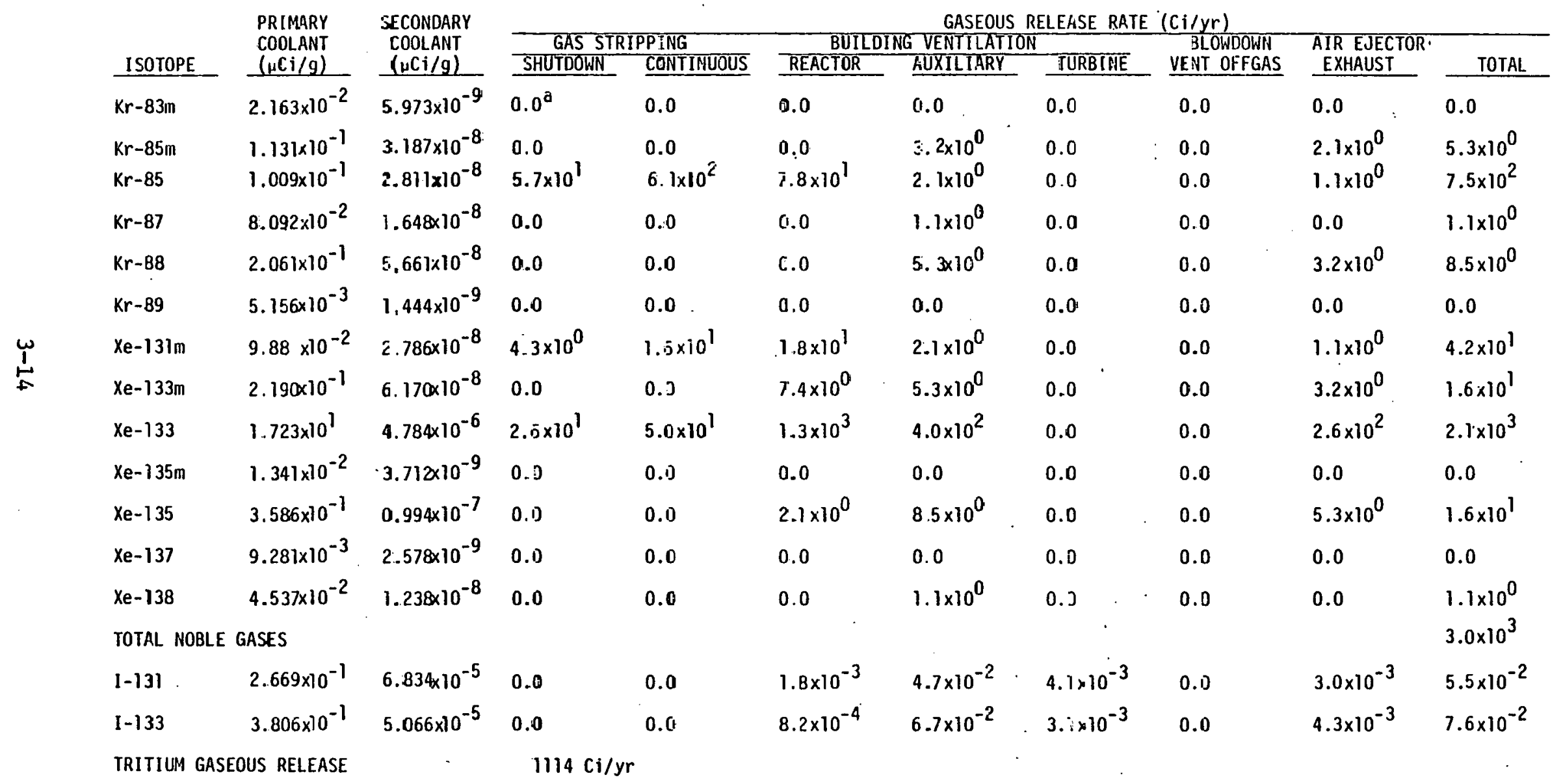

${ }^{\mathrm{a}}$ The figure 0.0 appearing in the table indicates that the release is less, than $1.0 \mathrm{Ci} / \mathrm{yr}$ for rosle gas, $0 . \mathrm{c} 00 \mathrm{C} \mathrm{Ci} / \mathrm{yr}$ for I. 
Table 3-4. Expected Annual Average Release of Airborne Radionuclides (Cont'd)

\begin{tabular}{|c|c|c|c|c|c|}
\hline \multirow[b]{3}{*}{ NUCLIDE } & & \multicolumn{3}{|c|}{ AIRBORNE PARTICULATE RELEASE RATE ( $\mathrm{C} i / \mathrm{yr}$ ) } & \multirow[b]{3}{*}{ TOTAL } \\
\hline & & \multirow{2}{*}{$\begin{array}{l}\text { WASTE GAS } \\
\text { SYSTEM }\end{array}$} & \multicolumn{2}{|c|}{ BUILDING VENTILATION } & \\
\hline & & & REACTOR & AUXILIARY & \\
\hline $\mathrm{Mn}-54$ & & $4.8 \times 10^{-3}$ & $6.5 \times 10^{-6}$ & $1.9 \times 10^{-4}$ & $5.0 \times 10^{-3}$ \\
\hline $\mathrm{Fe}-59$ & & $1.6 \times 10^{-3}$ & $2.3 \times 10^{-6}$ & $6.4 \times 10^{-5}$ & $1.7 \times 10^{-3}$ \\
\hline $\mathrm{Co}-58$ & & $1.6 \times 10^{-2}$ & $2.3 \times 10^{-5}$ & $6.4 \times 10^{-4}$ & $1.7 \times 10^{-2}$ \\
\hline Co- 60 & & $7.5 \times 10^{-3}$ & $2.3 \times 10^{-5}$ & $6.4 \times 10^{-4}$ & $7.7 \times 10^{-3}$ \\
\hline Sr -89 & & $3.5 \times 10^{-4}$ & $5.0 \times 10^{-7}$ & $1.3 \times 10^{-5}$ & $3.6 \times 10^{-4}$ \\
\hline Sr -90 & & $6.4 \times 10^{-5}$ & $9.0 \times 10^{-8}$ & $2.6 \times 10^{-6}$ & $6.7 \times 10^{-5}$ \\
\hline Cs-134 & 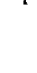 & $4.8 \times 10^{-3}$ & $6.5 \times 10^{-6}$ & $1.9 \times 10^{-4}$ & $5.0 \times 10^{-3}$ \\
\hline Cs -137 & & $8.0 \times 10^{-3}$ & $1.1 \times 10^{-5}$ & $3.2 \times 10^{-4}$ & $8.3 \times 10^{-3}$ \\
\hline
\end{tabular}

Note: In addition to these releases, $28 \mathrm{Ci} / \mathrm{yr}$ of argon-41 are released from the containment and $9 \mathrm{C} 1 / \mathrm{yr}$ of carbon- 14 are released from the waste gas processing system. 
Table 3-5. Expected Annual Average Releases of Radionuclides in Liquid Effluents

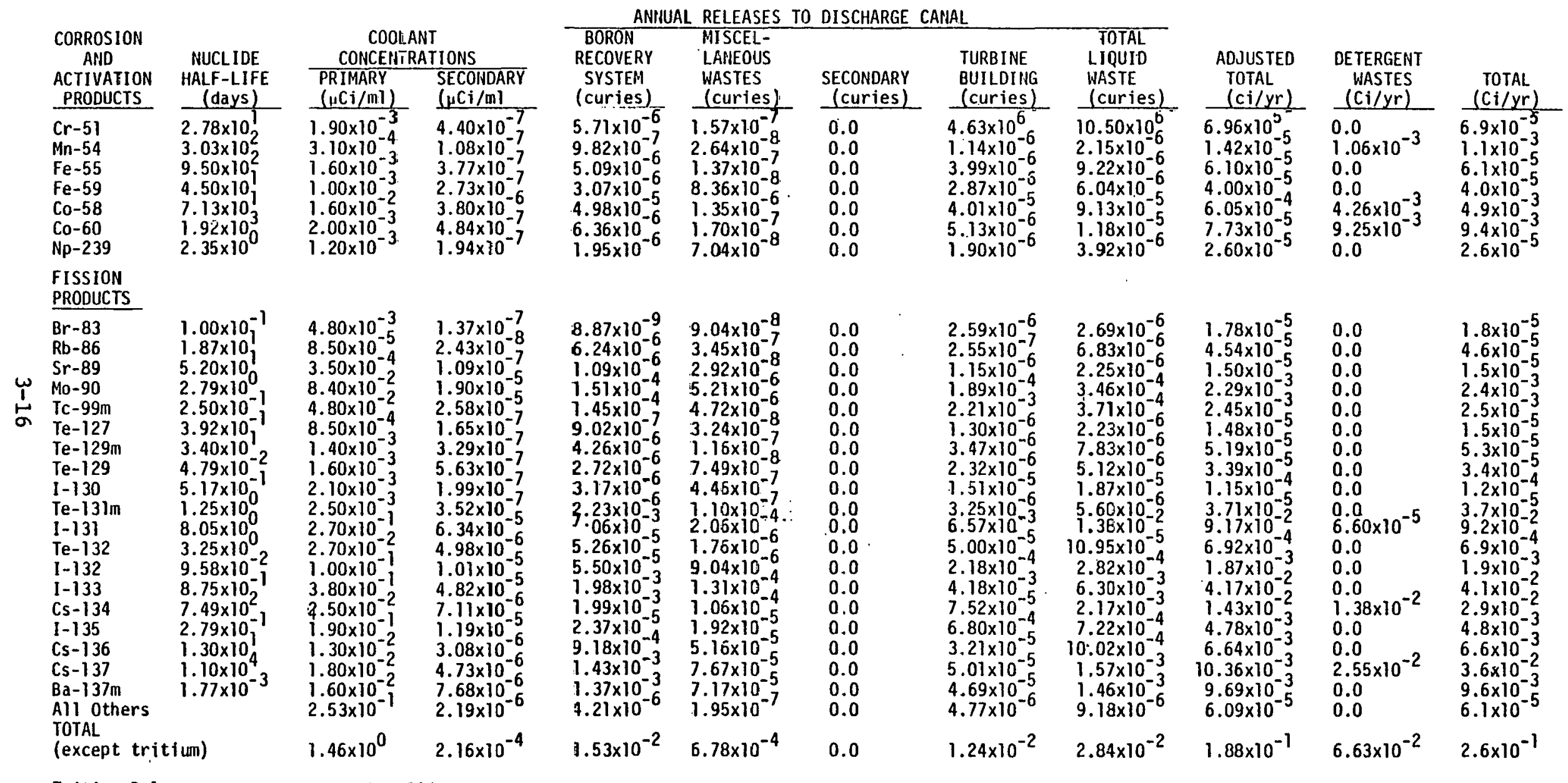

Tritium Release $404 \mathrm{Ci} / \mathrm{yr}$ 
Table 3-6. Annual Welght, Volume, and Activity of Radwaste Shipped

\begin{tabular}{|c|c|c|c|c|c|c|}
\hline TYPE OF WASTE & $\begin{array}{c}\text { WEIGHT } \\
\text { (Tons/day) }\end{array}$ & $\begin{array}{l}\text { SOLIDIFIED VOLUME } \\
\left(\mathrm{ft}^{3} / \text { day }\right) \\
\end{array}$ & $\begin{array}{l}\text { CATEGORY } \\
(\mathrm{S} . \mathrm{C})^{\mathrm{a}} \\
\end{array}$ & $\begin{array}{r}\text { SHIPPING } \\
\text { CONTAINER } \\
\end{array}$ & $\begin{array}{l}\text { CONTAINERS } \\
\text { SHIPPED } \\
\text { PER YEAR } \\
\end{array}$ & $\begin{array}{l}\text { ACTIVITY } \\
(\mathrm{Ci} / \mathrm{yr})^{\mathrm{b}} \\
\end{array}$ \\
\hline Bead Resins ${ }^{c}$ & 0.452 & 9.329 & s & $\begin{array}{l}\text { DOT } 17 \mathrm{C} \\
55 \text { gal. drum }\end{array}$ & 464 & 10,000 \\
\hline $\begin{array}{l}\text { Disposable Filter } \\
\text { Elements }\end{array}$ & 0.185 & 4.132 & $\mathbf{S}$ & DOT $17 \mathrm{H}$ & 201 & 315 \\
\hline $\begin{array}{l}\text { Evaporator } \\
\text { Ooncentrates }\end{array}$ & $\begin{array}{l}5.101 \\
\text { to } \\
5.888\end{array}$ & $\begin{array}{c}94.14 \\
\text { to } \\
107.01\end{array}$ & $\mathbf{S}$ & $\begin{array}{l}\text { DOT 17C } \\
55 \text { gal. drum }\end{array}$ & $\begin{array}{l}4,680 \\
\text { to } \\
5,253\end{array}$ & 516 \\
\hline $\begin{array}{l}\text { Compressed Waste } \\
\text { (Including pre- } \\
\text { and HEPA f1lters) }\end{array}$ & $\begin{array}{l}0.131 \\
\text { to } \\
0.146\end{array}$ & $\begin{array}{l}11.78 \\
\text { to } \\
13.35\end{array}$ & C & $\begin{array}{l}\text { DOT 17H } \\
55 \text { gal. drum }\end{array}$ & $\begin{array}{l}593 \\
\text { to } \\
669\end{array}$ & $\begin{array}{l}\text { very low } \\
\text { activity }\end{array}$ \\
\hline
\end{tabular}

a Key to radwaste category:

S - Solidified prior to shipment

C - Compacted, rags, paper, compressible waste

b

Activity at time of drumming except as noted

c The spent resin activity (bead resins) is calculated at the time the resin is transferred to the spent resin tank. This activity will be less if the resin is stored for a significant period of time. 


\subsection{LAND AND WATER USE}

Approximately 500 acres would be required for the primary plant site. This area includes an exclusion area of roughly 200 acres necessary for the positive control of all activities at the site. As shown previously in Figure 3-1, the site also has sufficient room for the construction of a second nuclear unit next to the original unit.

Consumptive water use results primarily from cooling tower evaporative losses, cooling tower blowdown, and general plant uses. By far, the largest consumers of water are the mechanical draft cooling towers. These towers use approximately 1 million gallons/hr. Table 3-7 identifies this and other plant water uses.

Table 3-7. Water Use In a 1250 MWe Iight Water Reactor

\begin{tabular}{|l|c|c|}
\hline \multirow{2}{*}{ WATER USE } & \multicolumn{2}{|c|}{ Million Gallons/Day } \\
\cline { 2 - 3 } & $100 \%$ Power & $70 \%$ Power \\
\hline Cooling Tower Evaporation \\
Cooling Tower Blowdown \\
General Plant Use
\end{tabular}

The primary sources of liquid effluents from a LWR facility include the cooling tower blowdown stream and process water effluent. No radioactive wastes are discharged in effluent streams, Rather, these waste streams, which are processed to remove radionuclides, are then discharged under controlled conditlons. Cooling tower blowdown does not contain any radionuclide contamination but does contain chemicals added for corrosion and biological growth control. Typical liquid effluent discharges must meet discharge 1imitations. The discharges are listed in the following table. 
Table 3-8. Waste Water Effluents - 1250 MWe LWR Facility at $70 \%$ Capacity Factor ( 9 )

\begin{tabular}{|l|c|}
\hline \multicolumn{1}{|c|}{ Pollutants } & Tons/Day \\
\hline Total Suspended Solids * & 1.043 \\
Total Dissolved Solids ${ }^{*}$ & 2.608 \\
Organics & 0.21 \\
Chlorine & 0.1 \\
Copper... & 2.8 \\
Chromium & 0.01 \\
Phosphate & 0.13 \\
\end{tabular}

$*$

Assuming a concentration factor of 4.5 tons/day in the cooling tower with $10 \mathrm{ppm}$ TSS and $25 \mathrm{ppm}$ TDS concentrations in the makeup water. 


\subsection{CONSTRUCTION AND OPERATION CHARACTERISTICS}

The construction of an LWR facility is subject to delays. Some delays have been experienced because of:

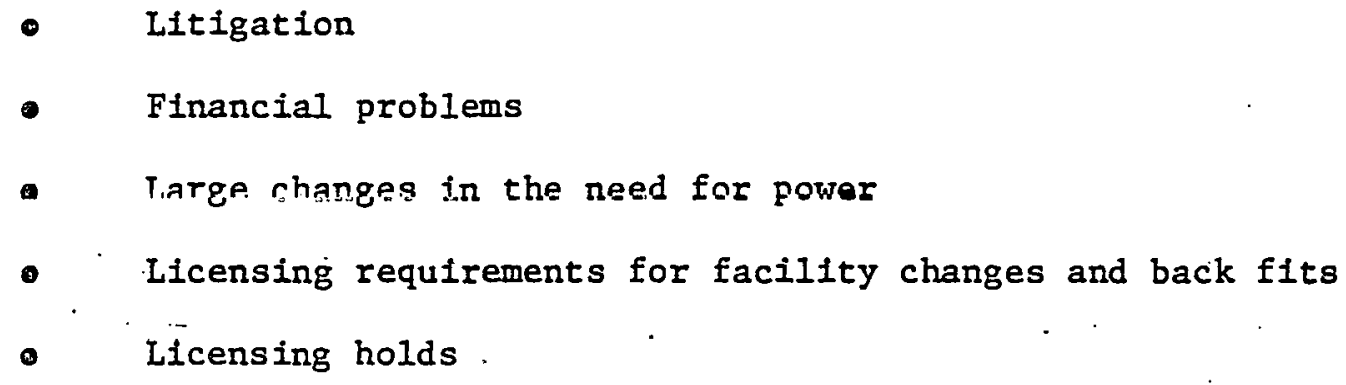

There are also other reasons for extended construction periods that have been experienced. Without any of these delays, a 1240 MWe LWR facility could be constructed in 6 years. If the delays expected to occur are included in this estimate, and licensing is also included (a two-step process with a construction permit and operating license included), the LWR facility could be completed in 12 years. (Recent experience is showing a trend toward 12-year construction times). During the on-site construction period, an estimated 11.54 million man-hours of direct craft labor would be required primarily from 16 different labor types as detailed in Table 3-9. Indirect labor hours are also included in the table.

Normal operation of the facility would require a plant staff averaging 215 persons and over 430,000 man-hours per year as shown in Table 3-10. The number of personnel on-site would vary considerably from time to time depending on the operation of the unit. When the unit is down for refueling/repair, the total number of personnel on-site would peak at a number considerably higher than 215 . 
Table 3-9. Direct Craft Labor Summary - 1250 LMFBR Plant Cost Basis - July, 1976

\begin{tabular}{|c|c|c|}
\hline CRAFT DESCRIPTION & $\begin{array}{l}\text { SITE } \\
\text { LABOR HOURS }\end{array}$ & $\begin{array}{c}\% \\
\text { HOURS } \\
\end{array}$ \\
\hline Asbestos Worker & 121,776 & 1.1 \\
\hline Boiler Maker & 678,055 & 5.9 \\
\hline Bricklayer & 129,520 & 1.1 \\
\hline Carpenter & 1,$379 ; 305$ & 12.0 \\
\hline Dock Builder & 3,255 & 0.0 \\
\hline Electrician & $1,858,431$ & 16.1 \\
\hline Iron Worker & $1,316,709$ & 11.4 \\
\hline Laborers & $1,299,695$ & 11.3 \\
\hline Millwrights & 172,227 & 1.5 \\
\hline Operating Engineers & 864,766 & 7.5 \\
\hline Painters & 203,580 & 1.8 \\
\hline Pipefitters & $3,193,846$ & 27.6 \\
\hline Plumbers & 682 & 0.0 \\
\hline Roofers & 12,775 & .1 \\
\hline Sheet Metal Workers & 125,700 & 1.1 \\
\hline Teamsters & 175,892 & 1.5 \\
\hline TOTAL DIRECT LABOR & $11,536,214$ & \\
\hline INDIRECT LABOR & $1,993,921$ & \\
\hline CONSTRUCTION SERVICES & $1,993,921$ & \\
\hline TOTAL & $15,524,056$ & 100.0 \\
\hline
\end{tabular}


Table 3-10. Staff Requirements for LWR Plant*

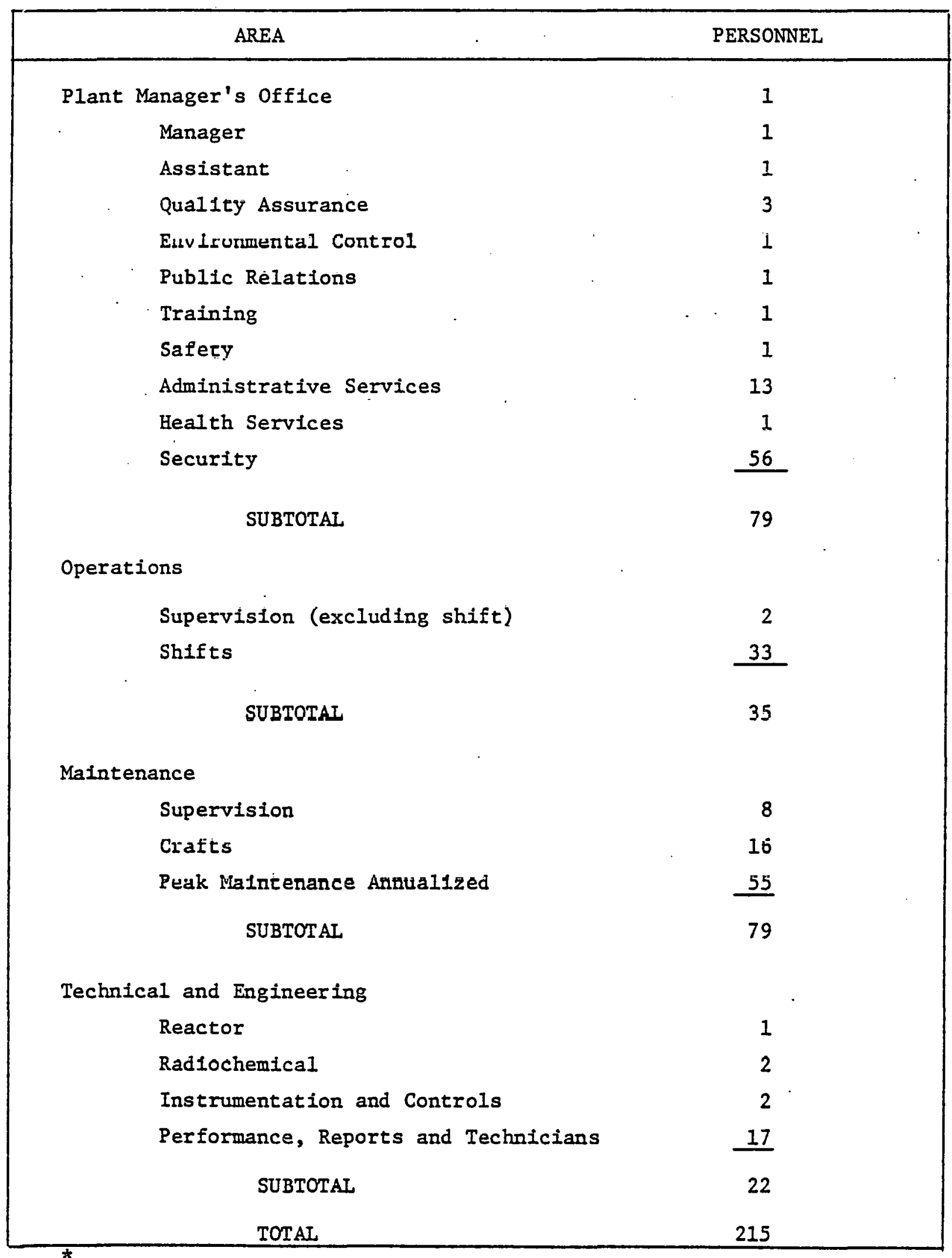




\subsection{OPERATING STATISTICS AND ANNUAL GENERATION}

Historical statistics on nuclear power generation facilities of this type indicate that the overall plant capacity factor would be $70 \%$. That is, the plant would produce $70 \%$ of the maximum possible kilowatt hours it could generate if it were operated continuously at full capacity.

Numerous parameters combine to produce this factor. These include plant downtime for scheduled maintenance plant forced outage rate due to unexpected component failure, and the customer load profile (including inter-utility sales of electricity). The first two factors combine to determine plant availability, whlle the inclusion of customer demand results in the plant capacity factor.

Typically, a large nuclear station, such as the type characterized here, would be placed first (or at least close to first) in the utility's loading order. Thus, it would not be affected by customer demand, since it could serve to satisfy part of the minimum customer load. If operated properly, all of the unit's output would be used to meet customer demand.

Scheduled maintenance and affecting outages for large nuclear facilities vary between 4 to 6 weeks per year. Recent forced outage rates range from 5 to 20.4 percent. In this case, 6 weeks of maintenance and refueling and a 20.4 percent forced outage rate is used to conservatively determine unit availability. Thus, plant availability is determined by:

$$
\text { Plant Avallability }=\frac{52-6}{52} \times(1-0.204) \times 100 \%=70 \%
$$

At this avallability and capacity factor, the reference $1250 \mathrm{MWe}$ LWR facility would generate $7.665 \times 10^{9}$ kilowatt-hours per year. 


\subsection{COST CHARACTERIZATION}

The basic capital costs estimated for the 1250 MWe reference light water reactor plant have been derived from detailed cost data presented in the "Energy Economic Data Base (EEDB) Program Phase I" report prepared for DOE by United Engineers and Constructors. Direct and indirect capital costs presented in the EEDB are on a consistent January 1, 1978 dollar basis. These costs are for the 1139 MWe ( $3425 \mathrm{MWt}$ ) Westinghouse reactor plant which provided the basis for the physical system characterization presented in the previous sections.

\subsection{DIRECT CAP̈ITAL COSTS}

The EEDB costs have been appropriately adjusted to reflect increased power levels and flow rates incorporated into the 1250 MWe reference light water reactor system. Specifically, the major modifications that affect the reference system's capital costs (as compared to the 1139 MWe EEDB design) include a $9.8 \%$ increase in the following system component capacities and design characteristics:

1. Main rnnlant flow through reactor voood

2. Steam flow through steam generators and turbines

3. Turbine shaft power, generator output, net plant capacity, and heat rejection system

Base direct capital costs includes the costs of all materials, components, structures, and associated direct craft labor necessary to construct the reference factilty at the plant site. Delivered costs for components, structures, and materials are used. Base indirect costs include site temporary construction facilities, payroll insurance and taxes, and other construction services, such as, home and field office expenses, field job eupervision, and engineering services. Specifically excluded from the base construction cost estimate are several items that are sensitive to the particular policies and preferences of the individual utility and to the specific plant site and prevailing economic factors being considered. These exclusions include the following list of items:

1. Owner's Costs - Consultants, Site Selection, etc,

2. Federal, State and Local Fees, Permits and Taxes 
3. Interest on Capital Construction Funds

4. Price Escalation during Construction

5. Contingency Funds

6. Owner's Discretionary Items - Switchyard and Transmission Costs, Waste Disposal Costs, Spare Parts, and Initial Fuel Supplies

By reviewing the detailed cost estimates made in the EEDB for the 1139 MWe reactor design at the "3-digit" subaccount level, we were able to estimate the 1250 MWe reference light water reactor system costs. Where appropriate, we adjusted the costs using the capacity ratio-exponent estimating technique. This technique, which is generally accepted by the electric power generation industry for making cost estimate modifications, uses the following equation to adjust. component costs for small to moderate changes in component capacity.

Cost of Component $B=$ Cost of Component $A \times\left(\frac{\text { Capacity of } B}{\text { Capacity of } A}\right)^{\alpha}$.

This equation applies where Component $A$ and Component $B$ are of similar design and performance, differing only in size of capacity, and where $\alpha$ is given by the following:

Account Description

$20^{\circ}$ Land and Land Rights

21 Structures and Improvements

22 Reactor Plant Equipment

Nuclear Steam Supply System (NSSS) Balance of Reactor Plant

23 Turbine P1anl Equlpment

24 Electric Plant Equipment

25 Miscellaneous Plant Equipment

26 Condenser Heat Rejection System
Cost Estimating Exponent : $(\alpha)$ Not Applicable

.20

.40

.30

.85

.37

.20

.50

Table 3-11 shows the original EEDB cost estimate by "2-digit" accounts. Also shown are the applicable cost estimating factors and the resulting 1250 Me reference system cost estimates. Costs for land would not vary measurably for the small incremental plant capacity considered here, so this account has been assigned a cost estimating factor of unity. The land costs shown assume the use of a 500 acre site valued at $\$ 4,480$ per acre. 
Table 3-11. Estimated Direct Capital Costs for 1250 MWe Light Water Reactor Reference System (January 1, 1978 Dollars)

\begin{tabular}{|c|c|c|c|c|}
\hline Account & Description & $\begin{array}{l}1139 \text { MWe EEDB } \\
\text { Cost } \$ 1000\end{array}$ & $\mathrm{CEM}^{(\mathrm{b})}$ & $\begin{array}{c}1250 \mathrm{MWe} \\
\text { Reference System } \\
\text { Cost } \$ 1000\end{array}$ \\
\hline 20 & Land and Land Rights & $2,240^{(c)}$ & 1.00 & 2,240 \\
\hline 21 & $\begin{array}{l}\text { Structures and } \\
\text { Improvements }\end{array}$ & 51,377 & $1.098^{0.20}$ & 52,347 \\
\hline 22 & $\begin{array}{l}\text { Reactor Plant Equip, } \\
\text { Nuclear Stream } \\
\text { Supply System } \\
\text { Balance of Reactor } \\
\text { Plant }\end{array}$ & $\begin{array}{l}73,255 \\
45,190\end{array}$ & $\begin{array}{l}1.098^{0.40} \\
1.098^{0.30}\end{array}$ & $\begin{array}{l}76,046 \\
46,475\end{array}$ \\
\hline 23 & Turbine Plant Equip. & 98,656 & $1.098^{0.85}$ & 106,816 \\
\hline 24 & Electric Plant Equip. & $.24,301$ & $1.098^{0.37}$ & 25,156 \\
\hline 25 & Misc. Plant Equipment & 9,755 & $1.098^{0.20}$ & 9,939 \\
\hline \multirow[t]{4}{*}{26} & $\begin{array}{l}\text { Condensate Heat } \\
\text { Rejection System }\end{array}$ & 16,161 & $1.098^{0.50}$ & 16,934 \\
\hline & $\begin{array}{l}\text { TOTAL DIRECT EQUIPMENT } \\
\text { AND MATERIALS }\end{array}$ & 320,935 & & 335,956 \\
\hline & Site Labor Costs & 145,132 & $1,098^{0.35}$ & 149,960 \\
\hline & $\begin{array}{l}\text { TOTAL DIRECT BASE } \\
\text { CONSTRUCTION COSTS }\end{array}$ & 466,067 & & 485,916 \\
\hline
\end{tabular}

(a) EEDB, Energy Economic Data Base

(b) CEM, Cost Estimating Multiplier, see text for discussion.

(c) Assumes 500 acres at $\$ 4480 /$ acre.

Average site labor costs for the 1139 MWe EEDB facility are estimated from approximately 11.13 milition man-hours at a craft-averaged cost of $\$ 13.04$ per man-hour. A cost estimating exponent of 0,35 hás been used to estimate the direct field labor requirements and costs. Resultant direct craft manhours for the reference facility are thus estimated to total 11,50 million man-hours, or nearly $\$ 150$ million.

\subsection{INDIRECT CAPITAL COSTS}

Indirect capital costs associated with the construction of large light water reactor power plants are relatively insensitive to the plant capacities used in the EEDB. Thus, except for payroll related expenses, indirect capital costs for the 1250 MWe reference light water reactor plant have been taken 
to be the same as those for the EEDB 1139 MWe plant, Construction payroll related expenses include payroll insurance and taxes as well as field job supervision costs. The latter was to be proportional to the reference system direct field labor costs. This assumption adds $\$ 802,000$ to the Construction Services account ( $\$ 91$ ) and $\$ 687,000$ to the Field Office Engineering and Services account ( $\$ 9.3)$ over those costs estimated in the EEDB.

Indirect capital costs, summarized in Table 3-12 at the "2-digit" account. level, total $\$ 197,109,000$, or about $41 \%$ of the direct capital costs estimated for the reference light water reactor system. These costs are more than twice the indirect costs associated with coal burning facilities of similar capacities. Safety and inspection requirements are a major contributor to this factor.

Table 3-12. Estimated Indirect Capital Costs for 1250 MWe Light Water Reactor Reference System (January 1, 1978 Dollars)

\begin{tabular}{|c|c|c|}
\hline Account & Description & $\begin{array}{l}1250 \text { MWe Reference } \\
\text { System Cost }(\$ 1000)\end{array}$ \\
\hline 91 & Construction Services & 74,982 \\
\hline 92 & $\begin{array}{l}\text { Home Office Engineering } \\
\text { and Services }\end{array}$ & 91,325 \\
\hline \multirow[t]{2}{*}{93} & $\begin{array}{l}\text { Field office Engineering } \\
\text { and Services. }\end{array}$ & 30,802 \\
\hline & TOTAL INDIRECT & 197,109 \\
\hline
\end{tabular}

\subsection{OPERATION AND MAINTENANCE COSTS}

Annual operation and maintenance (O\&M) costs for the 1250 MWe reference light water reactor facility have been estimated. These costs are based on cost estimating relationships presented in a recent Oak Ridge National Laboratory (ORNL) document entitled, "A Procedure for Estimating Nonfuel Operation and Maintenance Costs for Large Steam Electric Power Plants," and on data available in the EEDB.

Generally, O\&M costs for a nuclear power plant may be considered to be composed of six cost categories. The costs may be either fixed (not dependent on annual generation) or variable. The six categories considered here 
include: Plant Staffing, Maintenance Materials, Plant Supplies and Expenses (including radioactive waste disposal), Nuclear Liability Insurance and Inspection Fees, Interim Replacements and Administrative, and General Expenses.

Plant staffing costs are based on the 215 person plant staff described earlier and assumes a cost of $\$ 22,000$ per person per year. Maintenance materials have been found to average $100 \%$ of the maintenance staff costs ( 79 persons) for large nuclear generation plants and also have been found to be insensitive to plant capacity factors, thus, considered all fixed expenses. Fixed supplies and expenses, which include makeup chemicals, lubricants, and auxiliary fuels, as well as offsite contract services, radioactive waste management (exclusive of fuel), and non-radioactive waste management, have been estimated in the ORNL report to be $\$ 4.3$ million per year with a variable component of $.06 \mathrm{mills} / \mathrm{kWh}$. Nuclear 1iability insurance and inspection fees are estimated at $\$ 409,000$ per year with roughly $75 \%$ of this amount for private and government nuclear liability insurance. Administrative, overhead, and utility home office general expenses associated with the reference facility are estimated by ORNL to be $15 \%$ of the combined staff costs and fixed components of the materials and supplies costs. This compares to $10 \%$ of the same cost components for a conventional coal burning facility, with the increase primarily resulting from the larger amount of record keeping and safety related administrative costs necessary for the nuclear facility. Table 3-13 summarizes the O\&M costs for the reference nuclear light water reactor facility. 
Table 3-13. Annual Operation and Maintenance Costs--1250 MWe Reference Nuclear Light Water Reactor Facility @ 70\% Capacity Factor

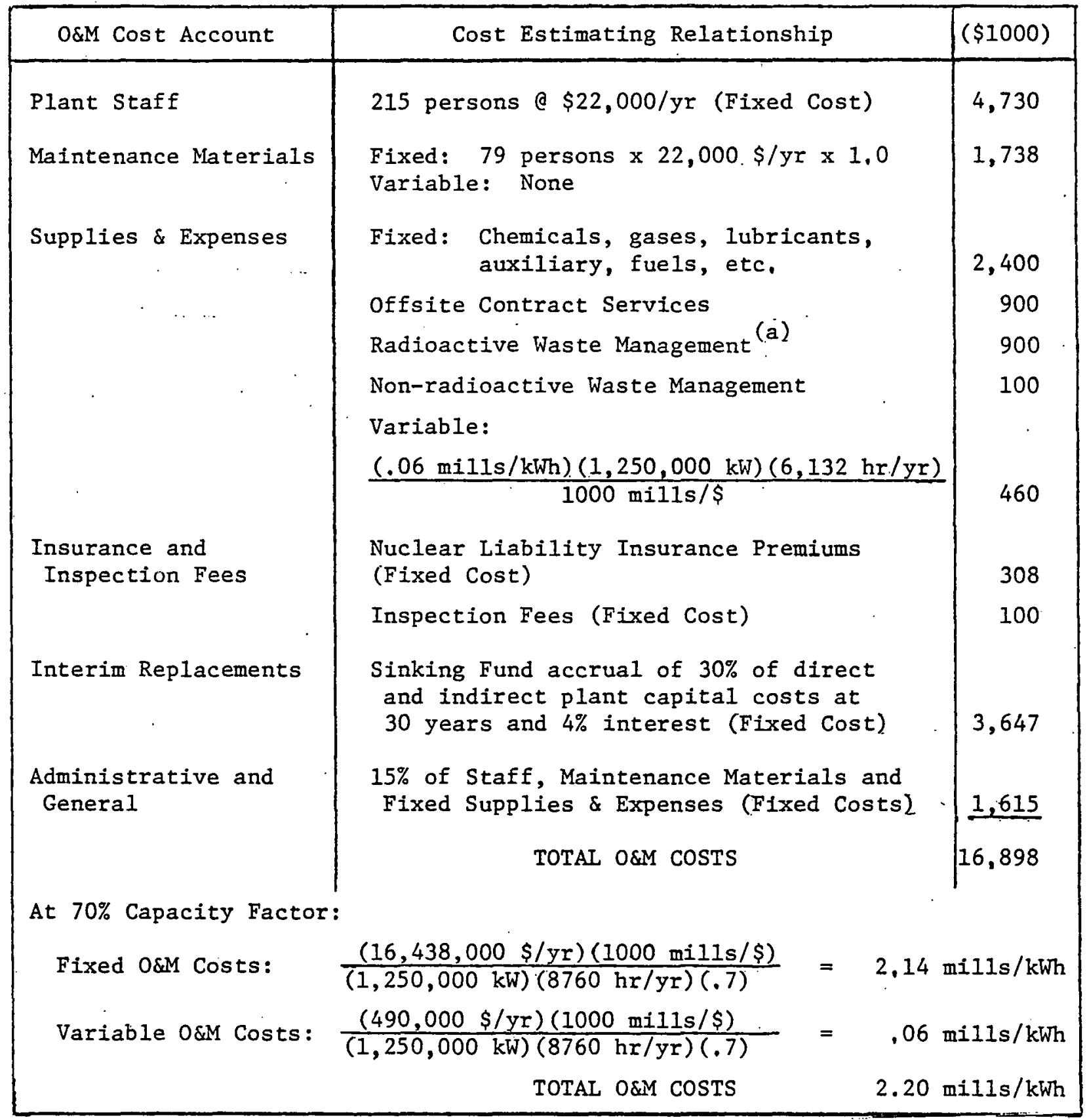

(a) Includes materials, packing, 1000 miles transportation, and final disposal costs.

(b) Annual hours of operation at $70 \%$ capacity factor. 


\subsection{NUCLEAR FUEL CYCLE}

This section of the report will characterize the nuclear fuel cycle for the LWR operating on a once-through fuel cycle. Figure 3-3 shows this fuel cycle. Figure 3-3 includes permanent disposal of the spent fuel in a geologic repository after a cool down period in the onsite fuel pool or at away-fromreactor (AFR) storage.

During each of the phases of the fuel cycle, liquid, solid, and gaseous effluents are produced to refect lieal. The following subsections quantify these emissions relative to providing fuel for a 1250 MWe nuclear power reactor. The primary sources of information are listed as references 3 and 7 , and were representative of a $1000 \mathrm{MWe}$ facilicy. S1nce the reference facility is a 1250 MWe unit, linear scaling was used in the following characterization.

\subsection{AIR EMISSIONS $(3,7)$}

\subsubsection{Mining}

- Chemical (tons/day)

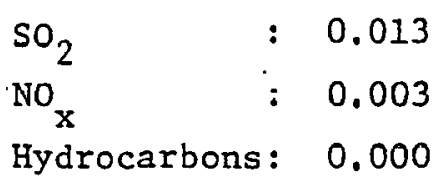

$\mathrm{CO}$

$$
\text { : } 0.000
$$

The primary chemical gaseous effluents derive from the burning of fossil fuels. Mining is accomplished by conventional deep mining techniques and open pit mining techniques. Standard diesel-fueled mining equipment is assumed.

- Radiological

Uranium and its daughters are released to the atmosphere when the ore body is exposed and broken up during underground or open pit mining operations. The airborne radionuclides discharged from underground willes are rapidiy diluted by forced. air circulation and atmospheric dispersion to normal background levels at the site boundaries. Attempts by the Bureau of Mines to measure radon concentrations in existing open pit mines revealed no significant alpha concentrations. Therefore, the concentrations of airborne radionuclides in unrestr1ced areas are expected to be undetectable. Mine tailings piles which have caused so much recent concern about radon emissions are scheduled to be cleaned up prior to year 2000 . 


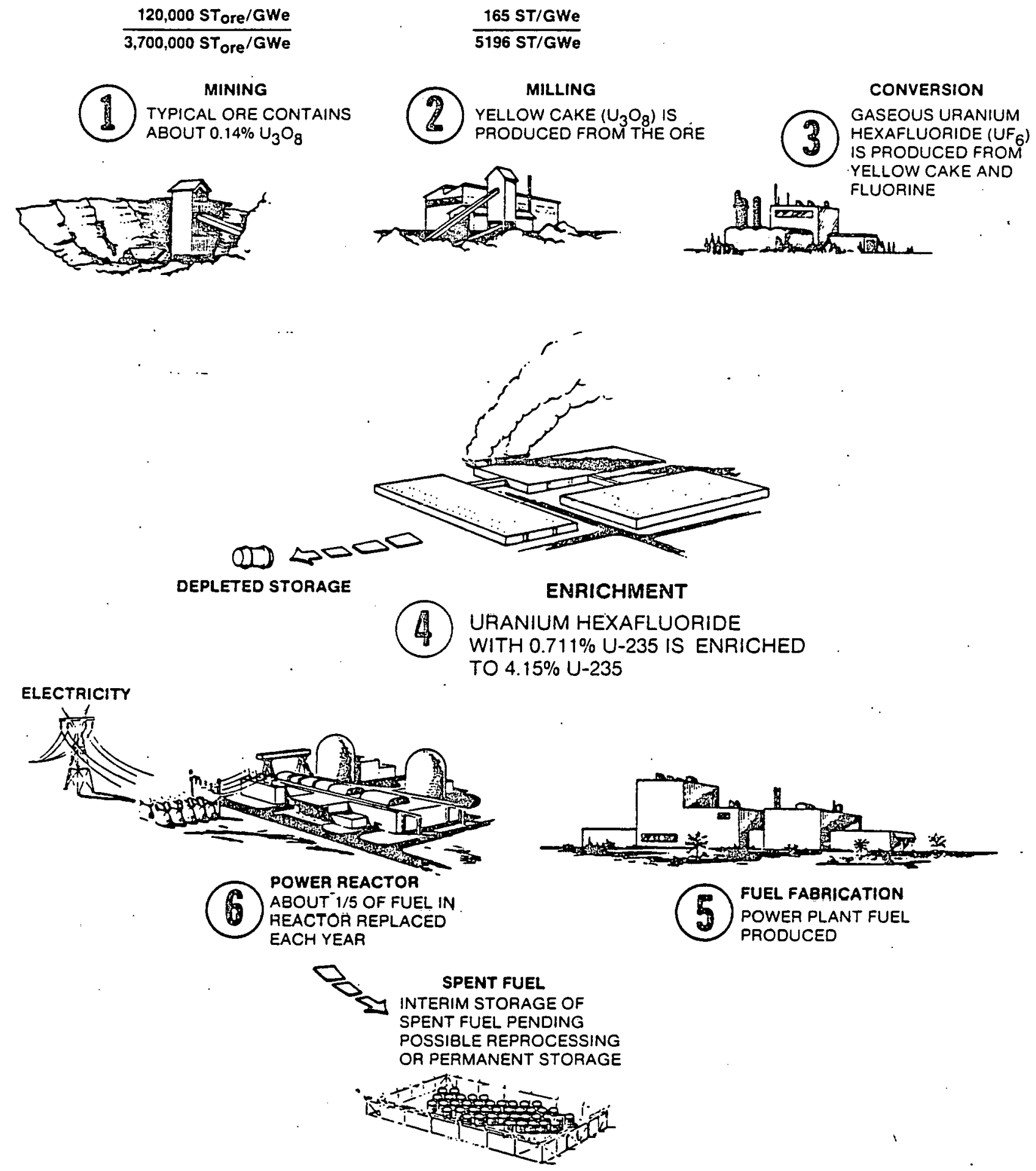

Figure 3-3. LWR Fuel Cycle 
7.1.2 Milling

- Chemical (tons/day)

$\begin{array}{lr}\mathrm{SO}_{2} & : 0.140 \\ \mathrm{NO}_{\mathrm{x}}(40 \% \text { from natural gas use }) & 0.060 \\ \text { Hydrocarbons } & : 0.005 \\ \mathrm{CO} & : 0.001\end{array}$

- Radiological (curies/year)

Rn-222 : 93.1

$\operatorname{Ra}-226 \quad \therefore \quad 0.02$

Th-230 : 0.02

$\mathrm{U}$ (natural): 0.03

In addition to the gaseous effluent release associated with the generation of electric power required by the mill, small quantities of sulfuric acid fumes, kerosene, and dust are released to the atmosphere from the uranium mill processes. In all cases, the airborne concentrations of these contaminants are maintained well below EPA standards. Deleterious effects on biota are highly unlikely.

Low level radiological airborne effluents consist of uranium and uranium daughter products. Conservative estimates of dispersion in the atmosphere predict site boundary concentrations in the range of less than $1 \%$ to $14 \%$ of Llie IImits of 10 CFR 20.

\subsubsection{Uranium Hexafluoride Production}

- Chemical (tons/day)

$\begin{array}{lll}\mathrm{SO}_{2} & : & 0.109 \\ \mathrm{NO}_{\mathrm{x}} & : & 0.038 \\ \text { Hydrocarbons } & : & 0.002 \\ \mathrm{CO} & : & 0.000 \\ \mathrm{~F}^{-} & : & 0.000\end{array}$

The emissions of $\mathrm{SO}_{2}$ and $\mathrm{CO}$ are effluent gases from combustion of equivalent coal fnr power generation. The effluents $\mathrm{NO}_{\mathbf{x}}$ and Hydrocarbons come from the combustion of coal and natural gas.

A number of process off-gases are generated in the preparation of $\mathrm{UF}_{6}$ from yellowcake. Most of these are combustion products but some are volatized solids and gases evolved during calcining and fluorlnation. Several off-gas 
treatments are applied to minimize the concentrations of airborne effluents released to the environment. Fluorides and oxides of nitrogen are the more significant sources of potential adverse environmental impact. Historically, analyses of airborne concentrations of fluoride as HF in air and concentrations in forage in the vicinity of a wet solvent extraction plant indicate fluoride levels below those expected to cause deleterious effects on human health or grazing animals. Long-term observation of an area within a 7 -mile radius of a hydrofluoride plant has not revealed any adverse effects attributable to fluoride releases from the plant.

- Radiological (curies/year)

Uranium: $\quad 0.017$

7.1.4 Uranium Enrichment

- Chemical (tons/day)

\begin{tabular}{|c|c|c|c|}
\hline & & Gaseous Diffusion & Centrifuge \\
\hline$* \mathrm{SO}_{2}$ & : & 16.200 & .648 \\
\hline${ }^{*} \mathrm{NO}_{\mathrm{x}}$ & : & 4.256 & .170 \\
\hline *Hydrocarbons & & 0.041 & .002 \\
\hline * $\mathrm{CO}$ & : & 0,106 & .004 \\
\hline $\mathrm{F}^{-}$ & $:$ & 0.002 & .002 \\
\hline *Particulates & & 4.256 & .170 \\
\hline
\end{tabular}

Starred estimated effluent gases are based upon combustion of equivalent coal for power generation assuming $100 \%$ load factor.

The primary source of environmental impact associated with the enrichment of uranium is related to the gaseous effluents from the coal-fired stations used to generate the required electric power.

Small quantities of airborne fluoride are generated at the diffusion plants. Measurements in unrestricted areas indicate concentrations which are below the range for which deleterious effects have been observed, and span the most restrictive state standard. In addition, oxides of nitrogen and sulfur are released at the diffusion plants. Conservative estimates of the off-site concentrations of these contaminants yield levels which are slightly below or are at EPA standards. Furthermore, the total quantity of these effluents is insignificant in comparison with the combustion products generated by the supporting electric power plants. 
The centrifuge enrichment process is scheduled to start operation in 1987. This process was only $4 \%$ of the power requirement of the diffusion process. Both processes will be operating in year 2000, and since SWH's will be produced at both facilities, origin cannot be firmly assumed. Hence, both processes are listed above.

- Radiological (curies/year; based on $4.15 \%$ isotopic enrichment) Uranium: 0.003

\subsubsection{Fuel Fabrication}

- Chemical (ton/day)

\begin{tabular}{|c|c|c|}
\hline$\therefore \mathrm{SO}_{2}$ & : & 0.086 \\
\hline$* \mathrm{NO}_{\mathrm{x}}$ & : & 0.022 \\
\hline *Hydrocarbons & : & 0.000 \\
\hline${ }^{*} \mathrm{CO}$ & : & 0.001 \\
\hline & 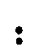 & 0.000 \\
\hline
\end{tabular}

Starred compounds in effluent gases are from combustion of coal for power generation.

The most significant effluents from the standpoint of potential environmental impact are chemical in nature. Nearly all of the airborne chemical effluents result from the combustion of fossil fuels to produce electricity to operate the fabrication plant. The anly slgnificant airborne chemical effluent from the process operations of the fabrication plant is fluorine. The fluorines which was introduced into the fuel cycle during the UF 6 production phase, becomes a waste product during the production of $\mathrm{UO}_{2}$ powder. The gaseous fluorine wastes generated are effectlvely rewoved from the air effluent streams by water scrubber systems. These wastes result in a site boundary concentration of roughly $6 \%$ of the most restrictive of a reference state's standard, $0,5 \mathrm{lg} / \mathrm{m}^{3}$.

- Radiological (curies/year)

Ụranium: $\quad 0.000$

\subsubsection{Power Plant}

The expected annual average release of airborne radionuclides is discussed in the previous section. 


\subsubsection{Waste Management (AFR Storage and Final Disposa1)}

No gaseous emissions are expected apart from those due to coal combustion which would provide the electricity for site operation,

\subsubsection{Transportation}

The primary source of gaseous emissions would be the combustion of approximately 13,400 gallons of diesel fuel resulting primarily in approximately 0.004 tons/day of No $x$.

7.2 LIQUID EFFLUENTS $(3,7)$

\subsubsection{Mining.}

The drainage water carries some suspended solids. The water quality can be nearly restored by settling pond treatment and natural seepage. Mine drainage water results from production necessary to supply the annual fuel requirement of the model LWR. The water can contain as much as several curies of radioactivity. This radiological liquid effluent results from dissolved and suspended uranium and its daughter nuclei. The activity is removed from the water and returned to the ground by ion exchange during seepage through the soil. When it is economically feasible, the uranium values are.recovered from the mine water before it is discharged.

\subsubsection{Miling}

- Chemical (tons/day)

Tailings Solutions: 904

I.iquid and solid chemical and radioluglcal wastes are discharged to the tailings retention pond. Operating experience has indicated that no significant adverse effect on the off-site environment is involved. After the model plant is decomissioned, the pond area is graded, covered with earth, and restored for limited use.

- Radiological (curies/year) Uranium and daughter nuclei: 1500 . 


\subsubsection{Uranium Hexaflouride Production}

- Radiological (curies/year)

$$
\begin{array}{ll}
\text { Ra-226: } & 0.034 \\
\text { Th-230: } & 0.034 \\
\text { Uranium: } & 0.034
\end{array}
$$

There are two major aqueous effluent streams associated with $\mathrm{UF}_{6}$ production. Many of the contaminants in this liquid effluent are in the raffinate stream from the solvent extraction process. The contaminants are not released to the environment but held indefinitely in sealed ponds. The second stream is made up mostly of cooling water and dilute scrubber solutions which represent the bulk of the water use. These aqueous effluents are treated with calcium to precipitate calcium flouride and diluted with all remaining clear water effluents from the plant before they are released. The solid calcium fluoride is recovered from settling ponds. Then they are packaged and, ultimately, buried,

\subsubsection{Uranium Enrichment}

- Chemical (tons/day).

$$
\begin{aligned}
& \mathrm{Ca}^{+}: 0.020 \\
& \mathrm{Cl}^{-}:=0.031 \\
& \mathrm{Na}^{+}: \quad 0.031 \\
& \mathrm{SO}_{4}=0.020 \\
& \mathrm{Fe}^{-}: 0.001 \\
& \mathrm{NO}_{3}^{-}: 0.010
\end{aligned}
$$

A number of chemical species are present in the liquid effluent stream from the plant. Calcium, chloride, sodium, and sulfate ions are major constituents of this stream. The concentrations of chemicals, however, undergo considerable dilution before reaching the receiving river. Additional dilution within the receiving river reduces all concentrations well below recominended permissible water quality standards,

- Radiological (curies/year based on $4.15 \%$ isotope separation)

Uranium: 0.02

Small fractions of a curie of uranium in gaseous liquid effluents are introduced into the environment. The result is concentrations in offsite air and water media which are less than $0.1 \%$ of the limits of 10 CFR 20 . 


\subsubsection{Fuel Fabrication}

- Chemical (tons/day)

$$
\begin{aligned}
& \mathrm{N} \text { as } \mathrm{NH}_{3}: 0.032 \\
& \mathrm{~N} \text { as } \mathrm{NO}_{3}^{-}: 0.020 \\
& \mathrm{~F}^{-} \quad: 0.001
\end{aligned}
$$

The most significant chemical species in liquid effluents are nitrogen compounds that are generated from the use of ammonium hydroxide in the production of $\mathrm{UO}_{2}$ powder and from the use of nitric acid in scrap recovery operations. The nitrogen concentrations in liquids released from the waste holding pond are about $420 \mathrm{mg} /$ iiter in the form of ammonia and $280 \mathrm{mg} / \mathrm{iiter}$ in the form of nitrates. The limiting concentration is for ammonia and requires dilution in the receiving stream by approximately three orders of magnitude. Depending on the nature of the receiving stream and its downstream uses, the nitrogen releases could constitute a significant impact on the enviroment.

Water from the scrubber systems is combined with process liquid wastes and treated with lime to form a calcium fluoride $\left(\mathrm{CaF}_{2}\right)$ precipitate, which is removed by filtration. The 32.50 metric tons of $\mathrm{CaF}_{2}$ filtered from the liquid per 1250 MWe LWR annual fuel requirement has a volume of about 13.75 cubic yards and is buried onsite with minimal disturbance of land.

The smali percentage of fluoride which is not removed by the lime treatment is released from the liquid waste holding ponds at a concentration of about $16 \mathrm{mg} / 1$ iter. Dilution in the receiving stream by approximately one order of magnitude io required to reduce this concentration to acceptable levels.

- Radiological (curies/year)

Uranium: 0.021

Th-234: 0.010

\subsubsection{Radioactive Waste Management}

No effluents to the off-site environment are expected.

\subsubsection{Transportation}

Non-significant level of effluents 
7.3 SOLID WASTE $(3,7)$

\subsubsection{Mining}

The primary solid waste material is the barren rock and earth overburden, the bulk of which is ultimately returned to the open pit as backfill.

\subsubsection{Milling}

- Chemical : Tailings, 0.342 tons/day

- Radiological: Uranium and daughter nuclei, 1500 curies/year

\subsubsection{Usanfum Hexafluoride Production}

- Chemical : 0.150 tons/day

- Radinlogicali 0.363 curles/year

The source of the radioactivity is from Thorium and occurs in the solid ash residue from hexafluoridation.

\subsubsection{Uranium Enrichment}

No significant effluents

\subsubsection{Fuel Fabrication}

- Chemical : Calcium flouride, 0.098 tons/day

- Radiological: Uranium, 0.076 suries/ycar

\subsubsection{Radioaclive Waste Management}

No effluents to the off-site environment are expected

\subsubsection{Transportation}

No significant level of effluents

7.4 WASTE HEAT $(3,7)$

7.4 .1 Mining

Approximately $313 \mathrm{MWh}$ of electricity are consumed to meet annual fuel requirements for 1250 MWe reactor. No significant environmental effects of heat release are anticipated.

\subsubsection{Milling}

$0.236 \times 10^{9} \mathrm{Btu} / \mathrm{day}$ will be discharged to the atmosphere. The effect on the environment will be undetectable except for some local fogging under certain meteorological conditions. 


\subsubsection{Uranium Rexafluoride Production}

$0.103 \times 10^{9} \mathrm{Btu} / \mathrm{day}$ will be discharged. No significant environmental effects are anticipated.

\subsubsection{Uranium Enrichment}

$10.96 \times 10^{9} \cdot$ Btu/day will be discharged. Approximately $67 \%$ of this heat is discharged by the electric generating plants servicing the enrichment plant (assuming $100 \%$ load factor for generating plant). Since the power is drawn from the grids of large utility complexes, the environmental impact is difficult to evaluate. The heat rejection at the enrichment plant site is largely to the atmosphere. Although occasional misting and fogging results within the site from operation of cooling towers, the thermal impact is insignificant.

\subsubsection{Fuel Fabrication}

$0.031 \times 10^{9} \mathrm{Btu} /$ day will be discharged. The thermal load carried by the cooling water is dissipated to the air when the water passes through the liquid waste holding pond and treatment ponds before it is released offsite.

\section{7,4.6 Radioactive Waste Management}

No effluents to the off-site environment are expected.

\subsubsection{Transportation}

Only the shipment of solid high level waste material will involve the release of a measurable but insignificant quantity of heat to the atmosphere. 7.5 DISRUPTION OF LAND AREAS $(3,7)$

\subsubsection{Mining}

Temporarily. committed undisturbed area: 47.6 acres

Temporarily comitted disturbed area : 21,0 acres/year

Permanently committed

Overburden moved

\subsubsection{Milling}

Temporarily comitted, undisturbed area: 0.26 acres (major portion included in mine land use)

Temporarily committed, disturbed area : 0.37 acres

Permanently cormitted (1imited use) : 2.96 acres 
of the approximately 3.6 acres of total land usage attributable to the model LWR annual fuel requirement, approximately 2.94 acres are devoted to a pond for the permanent disposal of mill tailings. In effect, nearly the entire mass of ore processed by the mill will be discharged to the tailings pond. Although the model plant tailings pond area will be restored to resemble the surrounding terrain after the 20 years of plant life, the land will most likely be removed from further restricted use, except (possibly) grazing.

\subsubsection{Uranium Hexafluoride Production}

Temporarily committed undisturbed area: 2.87 acres

Temporarily committed disturbed area : 0.31 acres

Permanently committed area $\quad: 0,02$ acreo

\subsubsection{Uranium Enrichment}

Temporarily comitted undisturbed area: 0.74 acres

Temporarily committed disturbed area : 0.26 acres

Permanently committed area : None

\subsubsection{Fuel Fabrication}

Temporarily committed undisturbed area: 0.20 acres

Temporarily committed disturbed area : 0.04 acres

Permanently comitted area : None

\section{5 .6 Power Plant}

The total cultivated agricultural land to be affected by the construction and operation is 500 acres. This includes an area for geographic isolation.

\subsubsection{Radioactive Waste Management}

Less than . 21 acres for storage of both high-level and other-than-highlevel wastes.

\subsubsection{Transportation}

None

\subsection{MANPOWER REQUUIREMENTS}

The exploration, mining, and milling of uranium ore is labor intensive, Mining and milling usually occur at or near the mine. Consequently, employment 
is usually expressed for all three functions (exploration, mining, milling). Recent data indicates the following:

Annual Production ore: 9,198,000T

$\mathrm{U}_{3} \mathrm{O}_{8}$ Content : $\quad 14,000 \mathrm{~T}$

Employment : $\quad 12,612$

Productivity (ore) : $\quad 729 \mathrm{~T} / \mathrm{man}-$ year 


\subsection{REFERENCES}

1. United Engineers and Constructors, Inc., Satellite Power System and Alternate Technology Characterization, UE\&C-ANL-790831, August 1979.

2. Westinghouse Electric Company, Final Safety Analysis Report, NRC: 1978 (as modified by TRW).

3. Westinghouse Electric Company, Environmental Report for Operating License, NRC.

4. Zaccari, D.R., and R.W. Hilles, Nuclear Plant Availability and Reliability, Electric Utility Engineering Conferences, Westinghouse Electric Company, 1979.

5. TRW Estimation.

6. Westinghouse Water Reactor Divisions, Summary Description of Westinghouse PWR Nuclear Steam Supply System.

7. Atomic Energy Commission, "Environmental Survey of the Uranium Fuel Cycle," Wash-1248, April 1974.

8. INFCE Working Group 8: Advanced Fuel Cycle and Reactor Concepts, Subgroup A: Once Through Fuel Cycles, Proposed Draft Paper, INFCE/WG, 8/USA/ DOC 12, May 31, 1978.

9. "Environmental Characterizations for Energy Technologies and End Uses, Volume III: Characterizations and Data in the Area of Nuclear Energy." Revision 1. Oak Ridge National Laboratory. November 17, 1978. 
SECTION 4. COMBINED CYCLE WITH INTEGRAL

LOW-BTU GASIFICATION 


\section{COMBINED CYCLE WITH INTEGRAL LOW-BtU GASIFICATION 。}

\subsection{INTRODUCTION}

This plant design is an integrated system, primarily consisting of a gasifier, an open cycle gas turbine, and a Rankine bottoming cycle. The basic cycle is modeled after a 579 MWe plant described in the Energy Conversion Alternatives Study (ECAS) (Reference 1). Reference was also made to other sources, such as the EPRI Preliminary Design Study for an Integrated Coal Gasification Combined Cycle Plant (Reference 2). The plant design was scaled to $1250 \mathrm{MWe}$.

The ECAS design utilizes the Alkazid desulfurization process system for gas cleaning and a mechanical draft cooling tower for condensate heat removal. At the time of its design (1977), this system just met the Environmental Protection Agency (EPA) new source performance standard (NSPD) for $\mathrm{SO}_{2}$ emissions of $1.21 \mathrm{~b} / 10^{6} \mathrm{Btu}$ by scrubbing about $88 \%$ of the gasifier output at a $90 \%$ removal efficiency. More recent EPA regulations now require a $90 \%$ removal of all stack gas $\mathrm{SO}_{2}$ for a facility of this type, and total $\mathrm{SO}_{2}$ are not to exceed an upper limit of $1.2 \mathrm{lb} / 10^{6} \mathrm{Btu}$. Since $\mathrm{SO}_{2}$ and $\mathrm{NO}_{\mathrm{x}}$ emissions are likely to be more severely restricted in the future, ECAS also produced an alternative design to comply with the gaseous fuel standards of $0.2 \mathrm{lbs} / 10^{6} \mathrm{Btu}$ for $\mathrm{SO}_{2}$ (and $0.7 \mathrm{lbs} / 10^{6} \mathrm{Btu}$ for $\mathrm{NO}_{\mathrm{x}}$ ). The plant designed for these more stringent standards had $99 \%$ of the output of the baseline plant. Its capital costs were $11 \%$ hlgher and its electricity costs $8 \%$ higher than the plant designed to less stringent emission standards. This design has been modified by ANL to comply with 40 CFR Part 60, Standards of Performance for New Stationary Sources, Gas Turbines. Promulgated on September 10, 1979, these standards apply to the gas turbine portion of a cumblned cycle steam/electric generating system. They limit the concentrations of exhaust gases as follows:

$$
\begin{aligned}
& \text { - } \quad \mathrm{NO}_{\mathrm{x}} \text { limited to } 75 \mathrm{ppm} \\
& \text { - } \mathrm{SO}_{2} \text { limited to } 150 \mathrm{ppm}
\end{aligned}
$$


At 15 percent oxygen and on a dry basis, this is equivalent to:

- $\mathrm{NO}_{\mathrm{x}}=0.34 \mathrm{1bs} / 10^{6}$ Btu of Fuel Gas

- $\mathrm{SO}_{2}=1.47 \mathrm{bs} / 10^{6}$ Btu of Fuel Gas

The characterization provided here is of a year-2000, $1250 \mathrm{MWe}$ high sulfur coal combustion facility with a suitable sulfur removal process. The plant capacity factor is assumed to be 70 percent. It is also assumed that the plant's fuel gas is processed to remove sufficient sulfur compounds to comply with the applicable standards. Although it is possible to achieve this removal efficiency with the Alkazid process, advances in sulfur removal systems anticipated between now and the year 2000 were taken into account. Other proprietary processes, such as Selexol (Allied Chemical Corporation) and stretford, could also be used to achieve adequate sulfur removal.

In this evaluation, such factors that are included are: (1) meeting other emission standards and (2) using alternative sulfur removal processes. 


\subsection{GENERAI PLANT CONFIGURATION}

- The plant arrangement drawings, showing the power plant equipment arrangement and the provision for onstte fuel and waste storage, are prepared for a typical plant site. The plant consists of two identical subplants, each producing one half of the full generating capacity.

Figure 4-1 shows the plant area which is surrounded by a perimeter road and has a 60-day dead storage coal pile and a 3-day live storage capacity. Storage facilities are provided for 15-day storage of ash discharged from the gasification module and sulfur generated from the Claus plant. The LBtu fuel plant and the power generation area are located adjacent to each other. Other plant support facilities, the switchyard and cooling towers, are also situated in the plant area. Important plant areas are described below:

\subsection{COAL HANDLING AND STORAGE}

The compacted dead storage pile is $50 \mathrm{ft}$ high with a base covering about 8.2 acres. This pile stores 480,720 tons of Eastern high sulfur coal for recovery with dozer tractors. Two conical live storage piles are provided covering an area of about 0.87 acres. These piles contain a total of 25,301 tons of coal available by gravity fed through underpile vibrating feeders to a conveyor belt that lifts the coal to feed hoppers. The hoppers sapply coal to the coal dryer and then to the crusher; the crushed overscreened coal $(1 / 4$ to $2 \mathrm{in})$ and the unscreened fines ( 0 to $1 / 4 \mathrm{in}$ ) are supplied to four gasification modules by parallel conveyors at an average combined feed rate of 502 tons/hr.

\subsection{IBtU FUEL PLANT}

The fuel plant consists of two gasification modules and gas cleanup systems. Each gasification module has two rows of 8 gasifier vessels each. The total plant. requirement is for 32 gasifier units. Normal operation will require 26 gasifiers on line, with 6 gasifierslin reserve or repair.

If more advanced entrained gasifiers are eventually used in this plant, then the number of gasifier modules would be smaller, (about 5 to 10). The entrained gasiflers are larger, with capacities up to 100 tons/hr. The cleanup system includes: (1) a serles of heat exchangers to cool the raw. 


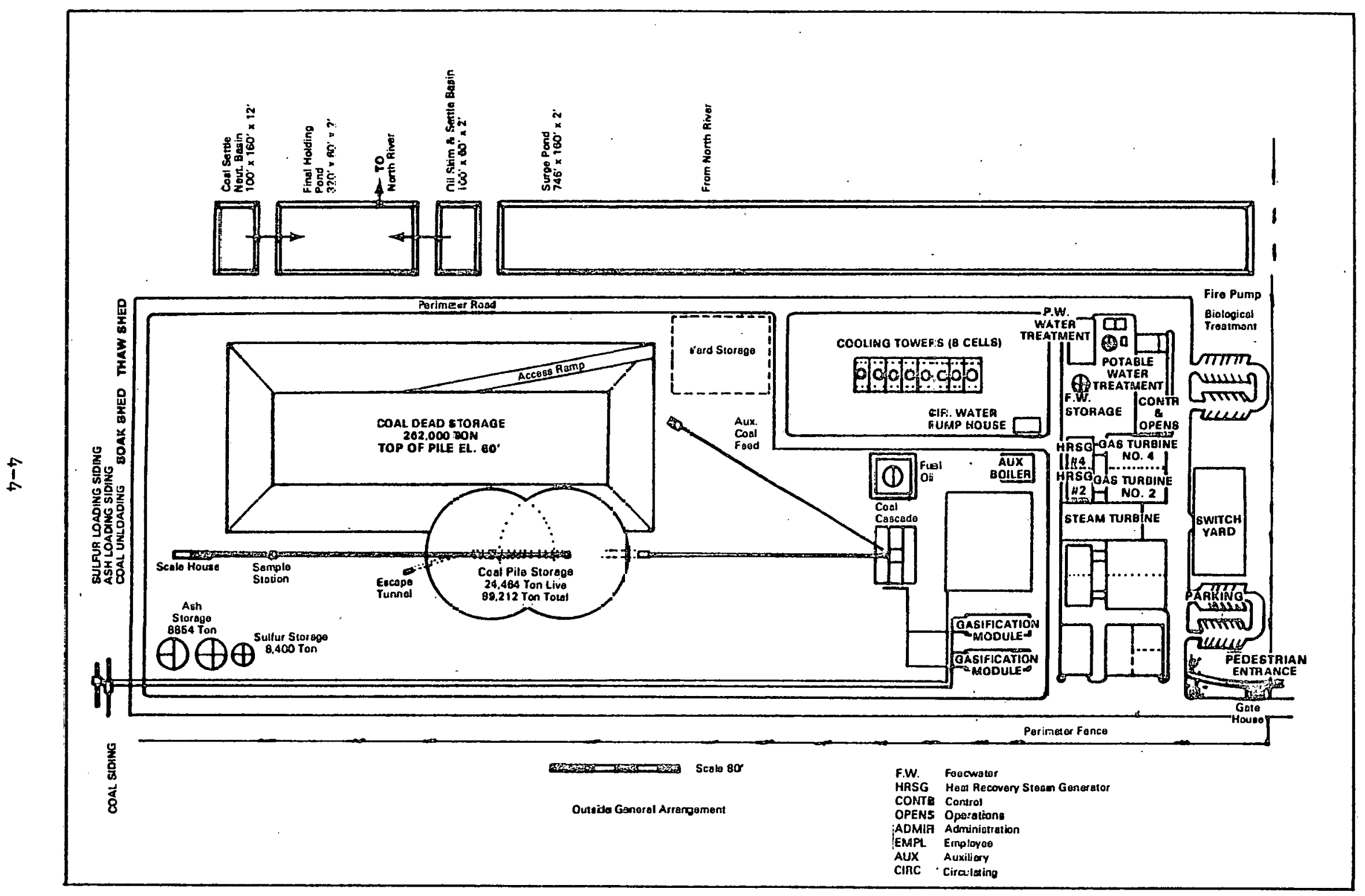

Figure 4-H. 1250 MWe Reference Coal Gasification Power Facility 
gas, (2) a Claus plant to convert $\mathrm{H}_{2} \mathrm{~S}$ to elemental sulfur, and (3) an incinerator.

\subsection{POWER GENERATION AREA}

This area includes two sets of four gas turbines. Each turbine is connected to a heat recovery steam generator (HRSG). The steam turbine building includes a reheat steam turbine, steam condenser and associated feedwater heaters, and pumps. The arrangement provides eight separate and parallel turbine gas flow paths, permitting independent operation of each gas turbine.

\subsection{SOLID WASTES HANDLING}

Ash from the gasification modules and dry sulfur from the Claus plants of the gas cleanup process are the solid waste products for this plant. Ash is produced at a nominal rate of 51.2 tons/hr which is conveyed to loading silos at the rail spur. A standby ash storage capacity of 18,425 tons is provided by two storage silos. Sulfur is produced at a nominal rate of 15.7 tons/hr. This is also conveyed to a loading silo at the rail spur. Two storage silos provide standby dry sulfur capacity of 5,672 tons.

\subsection{COOLING TOWERS}

For this plant, with a heat rejection load of $1.59 \times 10^{9} \mathrm{Btu} / \mathrm{hr}$, sixteen cooling tower cells and a water circulating capacity of 104, $153 \mathrm{gpm}$ were used.

\subsection{PONDS}

The surge pond and the waste-water pond have been sized for 3-day and 12-hour capacitles, respectively. The pond area is 32 acres.

\subsection{LOGISTICS AND OPERATION}

Coal is delfvered by unit trains to the fuel handling area adjacent to the coal storage piles. The fuel handling system has all of the necessary equipment to handle the coal gondolas in which the coal is supplied. There are facilities for thawing the cars in winter and a rotary car dumper. From the storage plies, the coal is moved by front-end loaders to a conveyor system. The coal is dryed, crushed, and remoisturized before being fed to lock hoppers on the gasifier. The coal is reduced to ash in the gasifier. About $99.9 \%$ of the ash is removed through the ash hopper lock at the bottom 
of the gasifier. The ash is consolidated and then permanently disposed of at an adjacent site. About $98 \%$ of the sulfur is removed from the claus sulfur recovery unit either for sale or disposal.

The gasifier output (fuel gas) goes to the gas turbine. The gas turbine exhaust drives the Rankine heat recovery (bottoming) cycle. The exhaust of the heat recovery boilers goes to the plant stack.

The main heat rejection system includes a makeup water intake and discharge, circulating water pump, and several mechanical draft wet cooling towers. Waste heat from the thermodynamic cycle is rejected to the steam cycle condensers in the form of heated water. Cooler water from the cooling towers circulates through the condensers to remove this heat and rejects it to the atmosphere in the form of convective and evaporative losses. 


\subsection{THERMODYNAMIC CYCLE CHARACTERISTICS}

The reference high sulfur coal generation facility is fired with Eastern High Sulfur Bituminous coal. The coal as received has a higher heating value (HHV) of $11,026 \mathrm{Btu} / 1 \mathrm{~b}$ and other constituents as shown in Table 4-1. The overall net plant efficiency, which accounts for in-plant auxilfary steam and electrical consumption, is $38.5 \%$. This facility thus requires 8,865 Btus of coal feed to produce one kilowatt hour of electricity. Figure 4-2 displays the major pieces of plant equipment in a simplified cycle schenatic and energy flow diagram of the reference design.

Table 4-1. Typical Eastern Bituminous HighSulfur Coal Characteristics

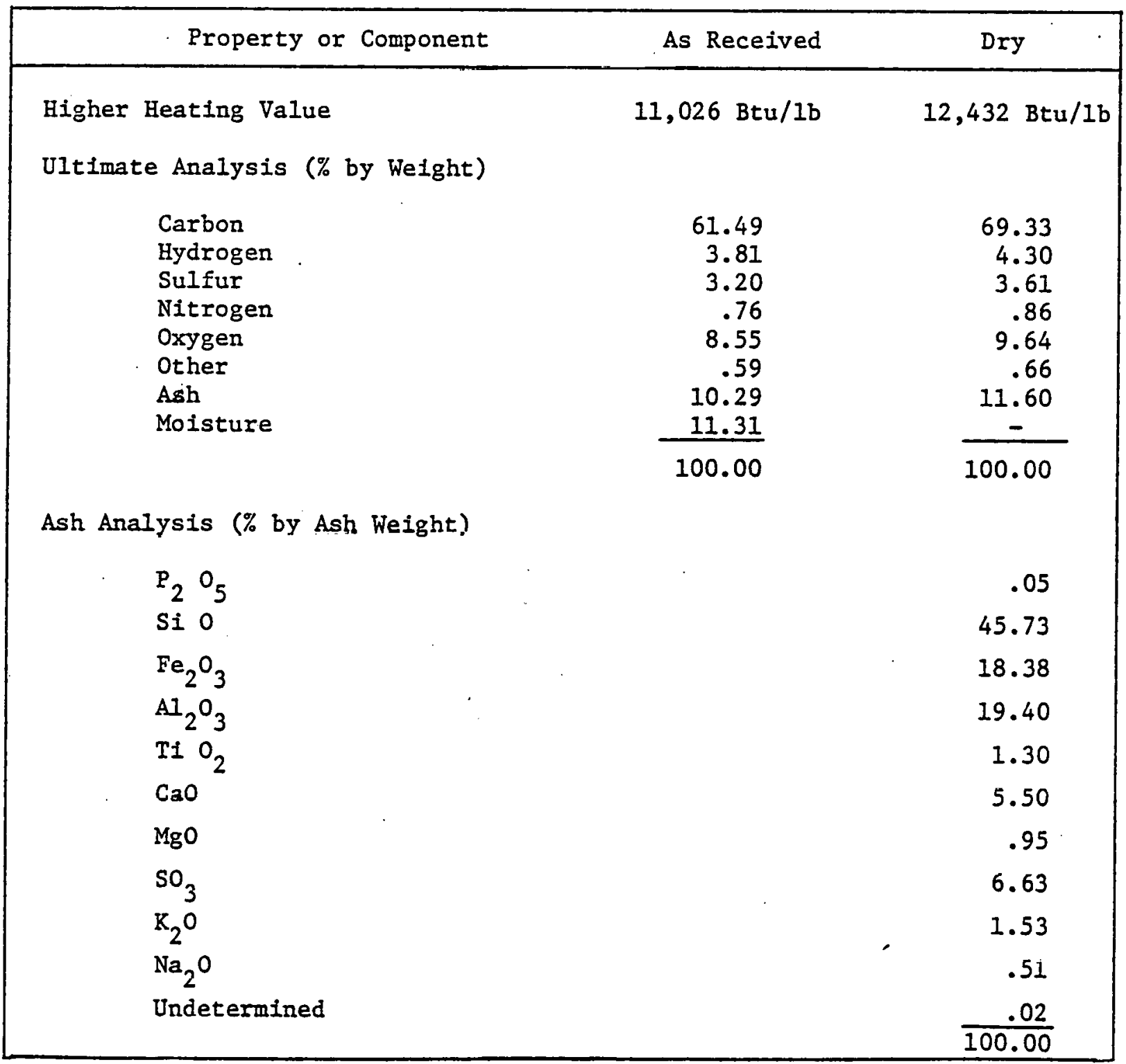




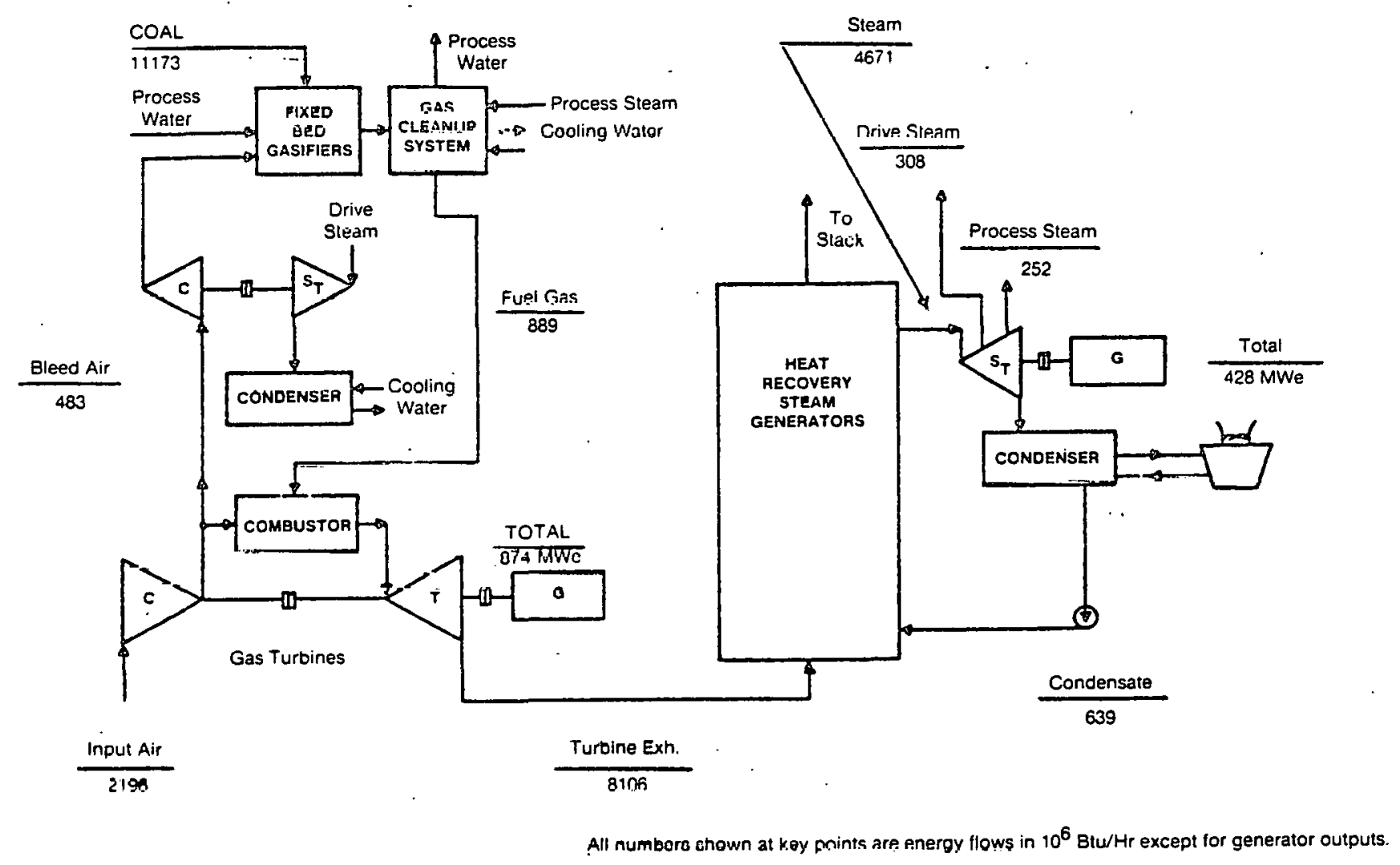

Figure 4-2. Simplified Schematic Diagram of Open Cycle Gas Turbine Combined - Air Cooled - LBtu Gasifier 
The fixed bed gasifiers generate LBtu gas which is chemically treated in the gas cleanup system. This ensures that the clean fuel supplied to the gas turbine combustors can meet the applicable $\mathrm{SO}_{\mathrm{x}}$ emission standards. The coal is fed to the gasifiers and then the process air required for the gasification process is extracted from the main gas turbine compressors. The process water supplied to the gasifier is preheated in the cleanup system.

The prime cycle consists of eight air-cooled gas turbine generator units, with a $12: 1$ compressor pressure ratio and $2400^{\circ} \mathrm{F}$ firing temperature (that is, the temperature at the inlet of the first-stage rotor). The prime cycle generates two-thirds of the total plant electrical power output. The gas turbine exhaust temperature is $1183^{\circ} \mathrm{F}$.

The bottoming cycle includes eight heat recovery steam generators (HRSGs) and two steam turbines. The HRSGs extract thermal energy from the gas turbine exhaust stream. The steam is supplied to steam turbine-generators contributing about one-third of the total plant power output.

The steam turbines provide process steam and steam for the boostercompressor-drive turbines.

The process steam is required for the gas cleanup system. Since the plant was designed for baseload service, no provision was made for gas turbine exhaust bypass around the HRSG.

Heat rejection to the cooling tower occurs from the bottoming cycle steam turbine, from the booster-compressor-drive turbine, and from the gas cleanup system. This plant requires 16 mechanical draft wet cooling towers.

The net power output from this plant is 1250 MWe.

\subsection{ADVANCED TECENOLOGIES}

The entrained bed gasifier involves a somewhat different thermodynamic cycle than the fixed bed system used as the basis of this analysis. The gasifier operates at lower pressures and higher temperatures than the fixed bed system. More heat is recovered from the gasifier output stream and utilized in the plant's steam cycle. Relatively higher pverall cycle efficiency up to $41.5 \%$ is possible, though some of this may be lost if tighter environmental standards are imposed. 
The simplified schematic of the reference plant with the thermodynamic conditions at the major process steps was shown previously in Figure 4-2. Each of the major components are described in the following paragraphs. Key parameters are summarized in Tables 4-2 and 4-3. For the purposes of discussion, the cycle is divided into the following seven categories:

- LBtu Fuel Plant

- Gas, Cleanup System

- Gas Turbine System

- HRSG-Steam Turbine System

- Feedwater System

- Steam Extractions

- Generation

These categories are discussed in the next section. 
Table 4-2. System Parameters Open Cycle Gas Turbine Combined-Air Cooled

FUEL

LBtu Gas (wet basis) Composition By Weight

$$
\mathrm{S}\left(\text { as } \mathrm{H}_{2} \mathrm{~S}+\mathrm{COS}\right)
$$

\section{GASIFIER}

Type

Operating Pressure (psia)

Cleanup System

PRIME CYCLE

Gas Turbine

Turbine inlet temp $\left({ }^{\circ} \mathrm{F}\right)$

Compressor pressure ratio

Working fluld

Turbomachinery configuration

Turbine exhaust $\left({ }^{\circ} \mathrm{F}\right)$

HEAT EXCHANGER

Heat Recovery Steam Generator

Vapor generator pinch point

$\Delta T(F)$

Exịt $\Delta T\left({ }^{\circ} \mathrm{F}\right)$

Gas side $\Delta p / p$

Drum to throttle $\Delta \mathrm{p} / \mathrm{p}$

Reheater $\Delta \mathrm{p} / \mathrm{p}$

Economizer $\Delta \mathrm{p} / \mathrm{p}$

BOTTOMING CYCLE

Steam Bottoming Cycle

Throttle temp ( $\mathrm{F}$ )

Throttle presfure (ps1)

Reheat temp ( $F$ )

Condensing pressure (in. Hga)

Feedwater temp ( ${ }^{\circ}$ F)

$$
\begin{aligned}
& \mathrm{HHV}=2959 \mathrm{Btu} / 1 \mathrm{~b}, \mathrm{LHV}=2745 \mathrm{Btu} / 1 \mathrm{~b} * \\
& 0.05 \%
\end{aligned}
$$

\section{Fixed Bed}

263

Alkazid + Claus for $\mathrm{H}_{2} \mathrm{~S}$ Removal

Cos Hydrolyzer and $\mathrm{NH}_{3}$ Removal

Air Cooled

2400

$12: 1$

Combustion gas

Axial-flow

Axial, 1183

$$
\begin{aligned}
& 18 \\
& 84 \\
& .05 \\
& .11 \\
& .10 \\
& .01
\end{aligned}
$$

HEAT REJECTION

Wet Cooling towers

Stack temperature $\left({ }^{\circ} \mathrm{F}\right)$

16 cells

312

*

Data on "dry equivalent" not supplied for standard conditions. 
Table 4-3. Summary of Design Parameters - Open Cycle Gas Turbine Combined Cycle with Low Btu Gasifier (Full Load Conditions)

\begin{tabular}{|c|c|c|}
\hline ENVIRONMENTAI IMPACT & $\begin{array}{l}\text { ECAS } \\
579 \mathrm{MW} \\
\end{array}$ & $\begin{array}{l}1250 \mathrm{MWe} \\
\text { Plant }\end{array}$ \\
\hline Coal Feed $(1 \mathrm{~b} / \mathrm{hr})$ ECAS/Example & 480,240 & $1,004,968$ \\
\hline$S$ in Feed $(1 \mathrm{~b} / \mathrm{hr}) \quad 3.9 / 3.2$ & 18.729 & 32,159 \\
\hline $\mathrm{N}$ in Feed $(1 \mathrm{~b} / \mathrm{hr}) \quad 1.0 / .79$ & 4,802 & 7,939 \\
\hline $\mathrm{C}$ in Feed $(1 \mathrm{~b} / \mathrm{hr}) 59.6 / 61.49$ & 286,223 & 617,955 \\
\hline Ash in Feed $(1 \mathrm{~b} / \mathrm{hr}) \quad 9.6 / 10.29$ & 46,103 & 103,411 \\
\hline $\mathrm{HHV}(\mathrm{Btu} / 1 \mathrm{~b})$ & 10,788 & 11,026 \\
\hline$\frac{\text { 1b. dry gas at saturator exit }}{\text { 1b. carbon in Feed }}$ & 4.5095 & 4.5093 \\
\hline$\frac{\text { 1b. dry gas at saturator exit }}{\text { Ib. Coal Feed }}$ & 2.6877 & 2.7728 \\
\hline $\begin{array}{l}\text { Clean gas at saturator exit } \\
\text { (wet) }(1 b / h r)\end{array}$ & $1,527,840$ & $3,279,793$ \\
\hline $\begin{array}{l}\text { Fuel gas consumed in gas cleanup } \\
\quad(w e t)(1 \mathrm{~b} / \mathrm{hr})\end{array}$ & 8,640 & 18,653 \\
\hline $\begin{array}{l}\text { Fuel gas combusted in turbines } \\
\text { (wet) (1b/hr) }\end{array}$ & $1,519,200$ & $3,279,793$ \\
\hline Gas turbine exhaust ( $1 \mathrm{~b} / \mathrm{hr}$ ) & 8,640 & 18,653 \\
\hline cos Hydrolysis Eff. (\%) & 100 & 100 \\
\hline $\mathrm{NI}_{3}$ Removal Eff. (\%) & 96.46 & 97 \\
\hline $\mathrm{NH}_{3}$ By-Product Production Total (1b/hr) & 3,920 & 9,068 \\
\hline Alkazid Removal Eff. (\%) & 97.84 & 95 \\
\hline Claus Removal Eff. (\%) & 95.00 & 95 \\
\hline $\begin{array}{l}\text { Sulfur By-Product Production } \\
\text { (Elemental) (lb/hr) }\end{array}$ & 17,830 & 29,917 \\
\hline Wellman-Lord Eff. (\%) & 98.50 & 90 \\
\hline $\begin{array}{l}\text { Wet Scrubber Eff. (Process Gases) (\%) } \\
\text { Heating Value of Fuel Gas } \\
\text { (wet) (Btu/lb) }\end{array}$ & 2,959 & $\begin{array}{r}85 \\
2,959\end{array}$ \\
\hline
\end{tabular}

*

$15.52 \% \mathrm{H}_{2} \mathrm{O}$ 
Table 4-3. Summary of Design Parameters - Open Cycle Gas Turbine Combined Cycle with Low Btu Gasifier (Continued)

\begin{tabular}{|c|c|c|}
\hline ENVIRONMENTAL IMPACT & $\begin{array}{l}\text { ECAS } \\
579 \text { MW }\end{array}$ & $\begin{array}{l}1250 \text { MWe } \\
\text { Plant }\end{array}$ \\
\hline Lime Requirement $(1 \mathrm{~b} / \mathrm{hr})$ & 1,500 & 2,434 \\
\hline Sludge Disposal $(1 \mathrm{~b} / \mathrm{hr})^{* *}$ & 1,550 & 6,076 \\
\hline $\mathrm{SO}_{2}$ Emissions $(1 \mathrm{~b} / \mathrm{hr})^{* * *}$ & & \\
\hline $\begin{array}{l}\text { Turbine Gases } \\
\text { Wellman-Lord } \\
\text { Wet Scrubber }\end{array}$ & $\begin{array}{r}782 \\
78 \\
39 \\
\end{array}$ & $\begin{array}{r}3,146 \\
316 \\
154 \\
\end{array}$ \\
\hline TOTAI & 899 & 3,616 \\
\hline $\mathrm{NO}_{2}$ Emissions $(\mathrm{lb} / \mathrm{hr})^{* * *}$ & & \\
\hline $\begin{array}{l}\text { Turbine Gases } \\
\text { Wet Scrubbers }\end{array}$ & $\begin{array}{r}819 \\
17 \\
\end{array}$ & $\begin{array}{r}743 \\
13 \\
\end{array}$ \\
\hline TOTAL & 836 & 756 \\
\hline $\mathrm{SO}_{2}$ Emissions (Ib/MBtu Gas) & & \\
\hline $\begin{array}{l}\text { Turbine Gases } \\
\text { Wellman-Lord } \\
\text { Wet Scrubber }\end{array}$ & $\begin{array}{l}.17 \\
.02 \\
.01 \\
\end{array}$ & $\begin{array}{l}.32 \\
.03 \\
.02 \\
\end{array}$ \\
\hline TOTAL & .20 & .37 \\
\hline $\mathrm{NO}_{2}$ Emissions (1b/MBtu Gas) & & \\
\hline $\begin{array}{l}\text { Turbine Gases } \\
\text { Wet Scrubbers }\end{array}$ & $\begin{array}{l}.182 \\
.004 \\
\end{array}$ & $\begin{array}{l}.077 \\
.003 \\
\end{array}$ \\
\hline TOTAL & .186 & .080 \\
\hline \# Gasifier Vessels (Operating/Standby) & $12 / 14$ & $2 \times 13 / 16$ \\
\hline Plant Heat Rate (Btu Coal $/ \mathrm{kWh}$ ) & 8,948 & 8,865 \\
\hline Plant Efficiency (\%) & 38.14 & 38.50 \\
\hline
\end{tabular}

$* *$

ECAS value likely in error or may be dry weight, this example uses relationship specified in ORNL O\&M cost document of 10 tons sludge per 4 tons lime feed. (Sludge $\simeq 50 \%$ water).

$* * *$

ECAS components do not derive from data specified in report-ECAS report seems to have many inconsistencies here. Total emissions based on $0.2 \mathrm{lb} / \mathrm{MBtu}$ gas with proportions roughly comparable to to those shown on Figure 4.6-17. (NO ${ }_{x}=.1861 \mathrm{~b} / \mathrm{MBtu}$ ) 


\subsection{LBTU FUEL PLANT}

The advanced fixed bed gasifier, producing a LBtu. fuel gas, has two major characteristics:

1. It handles more coal fines than state-of-the-art fixed bed gasifiers.

2. It allows maximum tar to recycle.

The ability to use more fines permits the use of conventional, low-cost coal crushing equipment. To ease the separation of coal fines, the incoming coal feed is first fired and then crushed to obtain 25 percent of the coal as fines. After fines separation, the crushed coal passes through a spray atation wlitere the coal moisture is restorcd to the oriy Inal level and then fed to the coal hoppers. The separated fines are mixed with the recycled tar in a mixer; the mixture is extruded and fed to screw conveyor feeding to the gasifier vessel.

The gasifier walls in the oxidation zone are cooled by water in the circulating jacket. Water at $330^{\circ} \mathrm{F}$ is supplied to the jacket from the gas cleanup system; the circulating water is flashed in a drum. The vapor generated is introduced into the gasifier vessel as part of the steam required for gasification process. The gasifier process air is extracted from the main compressor; this air is oaturated with water which serves as the remainder of the gasification process water requirement. A steam-driven booster compressor raises the pressure and delivers this air to the gasifier vessel.

The raw LBtu gas leaves the gasifier vessel at $865^{\circ} \mathrm{F}$. This gas passes through a series of saturator/washer-cooler vessels (two vessels per gasificr vesse1): the first vessel separates heavy tar from the raw gas, and the second vessel separates light tar oil, naphtha, and phenols. A major fraction of the heavy tar is recycled back to the gaolfier vessel. It is either mixed with coal fines or directly injected into the vessel. Saturated raw gas leaving the second vessel at $307^{\circ} \mathrm{F}$ enters the gas cleanup system. 


\subsection{GAS CLEANUP SYSTEM}

In order to meet the solid fuel emission standards, the hydrogen sulfide $\left(\mathrm{H}_{2} \mathrm{~S}\right)$ content of the raw gas must be reduced significantly. The Alkazid process selected here for this purpose requires that the gas be cooled to $100^{\circ} \mathrm{F}$. The $\mathrm{H}_{2} \mathrm{~S}$ removed from the gas is converted to elemental sulfur in the Claus plant.

The cleanup system includes an incinerator which oxidizes the heavy tar blowdown, the lock-hopper vent gas, and the tail gas from the claus plant. The thermal energy released through incineration is used to generate process steam and to heat process water. This internally generated process steam supplements the steam (at 65 psi) imported from the steam bottoming cycle, and meets the steam requirements of the Alkazid $\mathrm{H}_{2} \mathrm{~S}$ recovery unit.

The cleanup system requires a process water flow input; some of this water is heated to $330^{\circ} \mathrm{F}$ and is supplied as gasifier jacket cooling water. The cleanup system also has substantial heat rejection to the cooling tower, for which $21 \times 10^{6}$ 1bs. of cooling water per hour is required.

The clean gas finally leaving the cleanup system is saturated at $275^{\circ} \mathrm{F}$. The light tar oil, phenols, and naphtha removed from the raw gas stream earlier are added to the clean fuel gas. In order to avoid condensation in the fuel line, the gas is superheated to $300^{\circ} \mathrm{F}$ in a fuel-gas preheater before it is supplied to the combustor.

The composition of the low Btu gas is given in Table 4-4.

\subsection{GAS TURBINE SYSTEM}

This cycle employs eight air-cooled gas turbines, with a $12: 1$ compressor pressure ratio and a $2400^{\circ} \mathrm{F}$ firing temperature (that is, the temperature at the inlet of the first-stage rotor). Some of the compressor discharge air is used for turbine cooling. Part of this air is nonchargeable, that is, it enters the gas path before the first-stage rotor. The rest of the cooling air from the compressor discharge is chargeable. This chargeable air is cooled before injection into the turbine. Cooling air is also extracted from two Intermediate extraction points in the compressor. The cooling air from the higher pressure extraction point is also cooled prior to injection in the turbine. 
Table 4-4. Low Btu Fuel Gas Composition

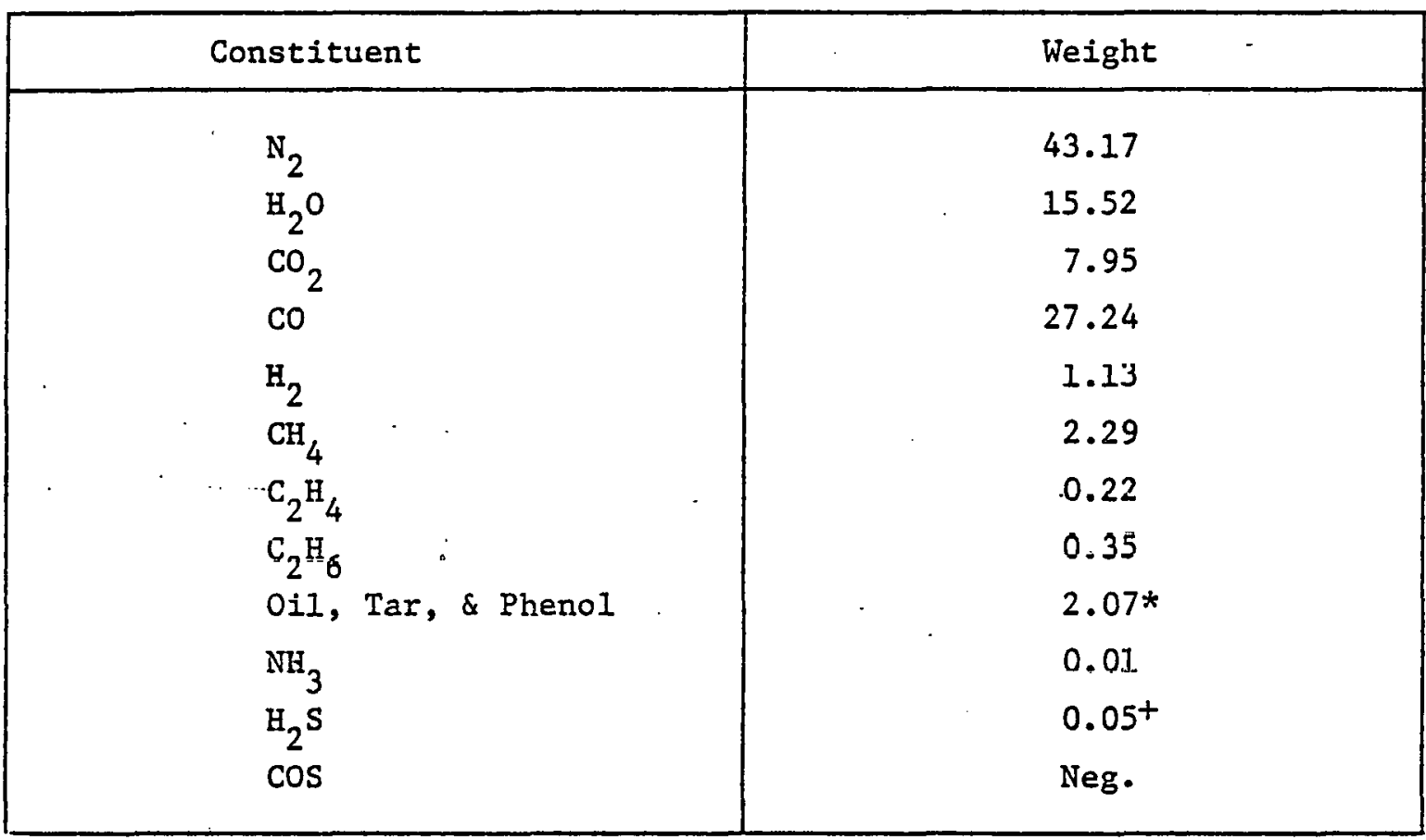

\footnotetext{
*

May be recycled in gas cleanup

+ Post cleanup
}

Since the fuel gas contains adequate molsture, additional steam injection in the combustor (for the purpose of $\mathrm{NO}_{\mathrm{x}}$ suppression) is not required. Each of the gas turbine units produces a net electric power of 108.8 MWe and has an exhaust gas temperature of $1183^{\circ} \mathrm{F}$.

\subsection{HRSG-STEAM TURBINE SYSTEM}

The heat recovery steam generator unit extracts thermal energy from the gas turbine exhaust flow stream and produces steam for use in a steam turbine system. One HRSG unit is provided for each gas turbine.

The HRSG unit consists of a horizontal reheater/superheater section followed by a vertical section comprising an evaporator, an economizer, and a drum. The combustion gas entering the HRSG unit at $1183^{\circ} \mathrm{F}$ is cooled down to $413^{\circ} \mathrm{F}$ at the exit of the economizer. This gas is further cooled to $334^{\circ} \mathrm{F}$ by using a low-pressure economizer that transfers the thermal energy from the gas steam to the feedwater heater train. This low-pressure economizer section is located above the high-pressure economizer section. The combustion gases pass through a silencer before entering a stack. A fraction of the 
stack gas $(\approx 10$ percent) is used to dry the coal in a coal dryer and is returned to the stack. The temperature of the gas discharging through the stack is $312^{\circ} \mathrm{F}$.

The steam cycle conditions are selected to be $1800 \mathrm{psig}$ and $950^{\circ} \mathrm{F}$. The feedwater temperature is $259^{\circ} \mathrm{F}$, and the condensing pressure is $2.3 \mathrm{in}$. Hga. One steam turbine serves each four HRSG units, with a net power output of 428 MWe from the two units.

\subsection{FEEDWATER SYSTEM}

Steam condensates from the main steam turbine and the booster turbine, along with the treated makeup water, are pumped to the deaerator tank by a condensate pump. Water from the deaerator tank is circulated through the low-pressure economizer loop. The economizer discharge is supplied to a flash tank at 30 psia; saturated vapor from the flash tank is condensed in the deaerator heater; and the liquid is fed back to the deaerator tank. The deaerator removes noncondensible gases from the feedwater. The energy input from the low-pressure economizer loop is sufficient to maintain the desired deaerator conditions, and no steam extraction from the steam turbine is required. The deaerator tank at 30 psia supplies the feedwater to the feedpump.

\subsection{STEAM EXTRACTIONS}

The cycle has three steam extractions from the steam turbine:

1. For the Booster Steam Turbine Drive: Steam from the cold reheat point (that is, after expansion through the high-pressure turbine) is supplied to the two steam turbines driving the booster compressors. The condensing conditions are taken at 2.3 In. Hga. Part of the condensate is sprayed into the air saturator, and the remaining is pumped back to the feedwater train.

2. For the Fuel-Gas Preheater: Steam at 82 psi is supplied to the heater to super heat the LBtu fuel gas.

3. For the Gas Cleanup System: The external process steam demand for the gas cleanup system is satisfied by extracting steam at 68 psi from the steam turbine and mixing it with the hot water discharged from the fuel-gas preheater. 


\subsection{GENERATION}

The plant's thermodynamic cycles accomplish generation within two of its parts. Generation is done by the net output of the gas turbines and Rankine heat recovery (bottoming cycles). All generators operate synchronously at $60 \mathrm{~Hz}$. They feed a common switchyard at the plant site. Generation capacity and internal (auxilfary) use are summarized as follows:

$\begin{array}{lr}\text { Total prime cycle (gas turbine) (8 units) } & 884.1 \\ \text { output (MWe at } 60 \mathrm{~Hz} \text { ) } & 417.1 \\ \text { Total bottoming cycle (steam turbine) (2 units) } & \\ \quad \text { output (MWe at } 60 \mathrm{~Hz} \text { ) } & 1301.2 \\ \text { Total gross output (MWe at } 60 \mathrm{~Hz} \text { ) } & 51.2 \\ \text { Total auxiliary losses (MWe at } 60 \mathrm{~Hz} \text { ) } & 1250 . \\ \text { Net power plant output (MWe at } 60 \mathrm{~Hz} 500 \mathrm{kV} \text { ) }\end{array}$

\subsection{FUELS USE AND LOGISTICS}

This plant uses high sulfur coal (typically eastern high sulfur bituminous coal) to generate a net capacity of 1250 whe with an assumed capacity factor of $70 \%$. A detailed heat balance shows that 8865 Btu of pulverized coal is required to generate one kilowatt-hour of net output this corresuponds to a net plant efflciency of $38.5 \%$. The coal characteristics chosen assume a higher heating value of $11,026 \mathrm{Btu} / \mathrm{lb}$ of coal on an as received besis. Al full capacity, coal feed is required at a rate of $502 \mathrm{tons} / \mathrm{hr}$. or $3.08 \times 10^{6}$ tons/year at $70 \%$ capacity factor. At this rate, an average of 8,434 tons of coal would be delivered to the site each day; as coal storage requirements are estimated at full capacity factor, a 3-day live storage stock pile would contain 25,301 tons of coal, and a 57 day reserve storage would contain 480,720 tons of coal.

The average storage density of utflity coal in live storage is 960 tons/ acre-ft and reserve storage density averages 1176 tons/acre-ft. Assuming $30 \mathrm{ft}$ high active storage and $50 \mathrm{ft}$ high reserve storage results in a site area of about 9 acres devoted to coal storage and handling. 


\subsection{ENVIRONMENTAL CHARACTERISTICS}

\subsection{OVERALL ENVIRONMENTAL IMPACT}

Figure 4-3 depicts the major environmental impact of fossil fuel plants which arise from the impurities in the fuel and water used by the plant. The major impurities in the fuel are the sulfur and nitrogen compounds and incombustible ash. In the gasification step, almost all of the ash is separated from the coal, so it does not show up as a potential air pollutant. However, it represents a slzable solid waste disposal problem. Simllarly, about 93\% of the sulfur is removed from the process stream by the combined Alkazid-Claus process. This sulfur may be sold as an industrial by-product or disposed of in a landfill. Another $1.3 \%$ is disposed of in the scrubber sludge from the wet limestone scrubber. The remaining sulfur appears as $\mathrm{SO}_{2}$ in the stack gas from the various plant flues and exhausts. $\mathrm{NO}_{2}$ control is effected by removing most of the $\mathrm{NH}_{3}$ from the fuel gas streams before combustion.

Water used for plant cooling also is a source of environmental pollution. As the water is evaporated, concentrations of dissolved solids increase. This brackish "blowdown" water must be specially handled, to avoid pollution of local water systems.

Plant siting must take all of these factors into account to select a location in compliance with all applicable emissions and land use criteria. Primary factors affecting the siting of a combined cycle plant are water availability and Federal, state and local emission regulations. The plant desigi used in this characterization satisfled the gas turbine and combined cycle plant emission standards for new sources. (EPA New Source Performance Standards -40 CFR Part 60.) Other considerations affect siting of the plant such as local impacts on achleving ambient quality standards or criteria for prevention of significant deterioration.

\subsection{FUEL GAS CLEANUP SYSTEM - SULFUR}

The cleanup system must remove enough sulfur as elemental sulfur so that the sum of the $\mathrm{SO}_{2}$ emitted with incinerator flues and the $\mathrm{SO}_{2}$ emitted with the power plant flues will be no greater than allowed by the EPA Standards. The $\operatorname{COS}$ formed in the gasifier and entering with the raw gas will be hydrolyzed to $\mathrm{H}_{2} \mathrm{~S}$ before entering the Alkazid plant. Virtually all the cos is hydrolyzed 


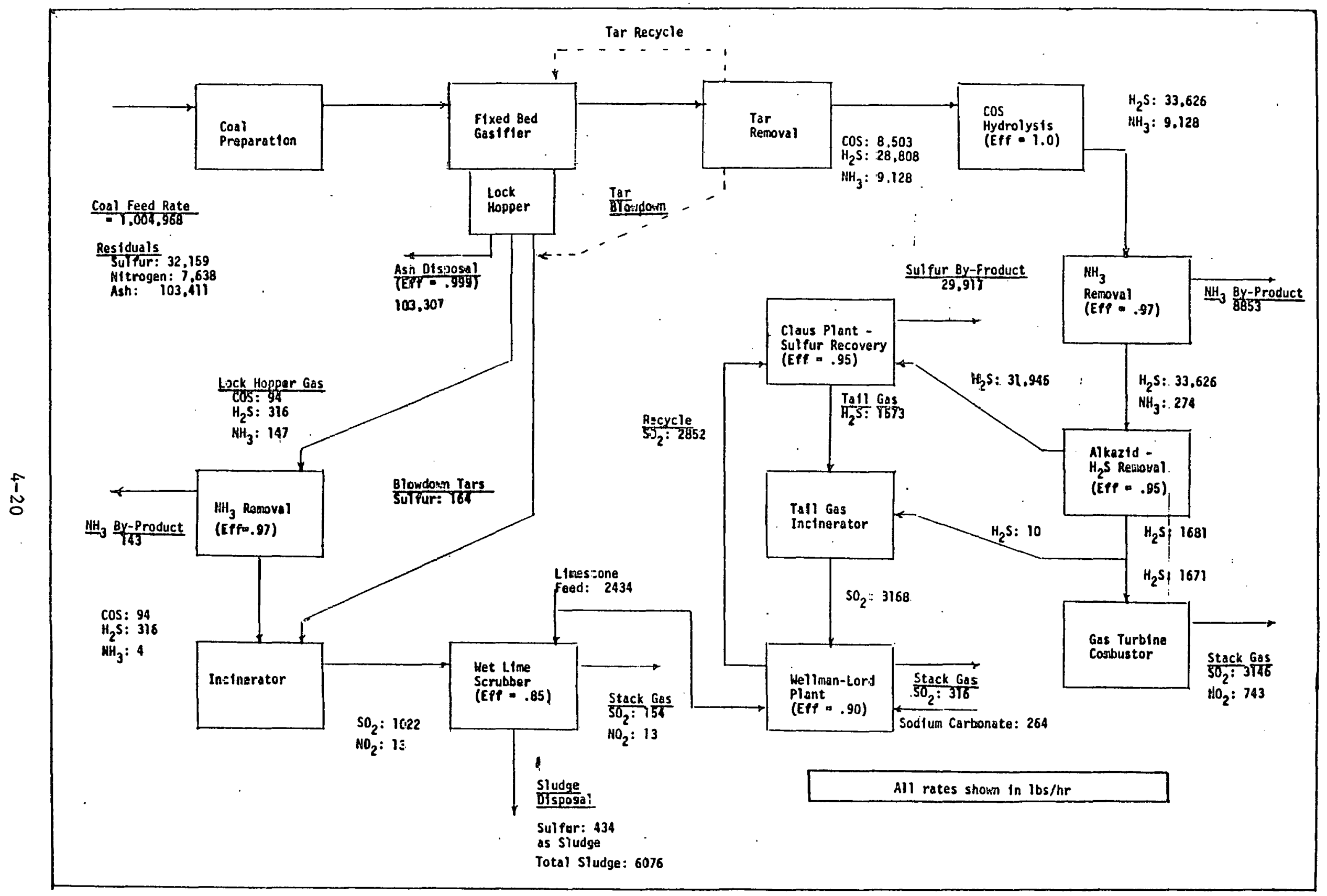

Figure 4-3. Environmental Residuals Sunmary for 1250 MWe Low Btu Gasifier Combined Cycle Flant 
to $\mathrm{H}_{2} \mathrm{~S}$ for removal. The Alkazid plant removes $\mathrm{H}_{2} \mathrm{~S}$ from the product gas to a level which allows the limit to be met. Of the $\mathrm{H}_{2} \mathrm{~S}$ removed by the Alkazid plant, 5\% will not be converted to elemental sulfur in the Claus plant. This $5 \%$ of the $\mathrm{H}_{2} \mathrm{~S}$ will be converted to $\mathrm{SO}_{2}$ when the tail gas is incinerated. The tail gas is treated in the Wellman-Lord plant, which allows $90 \%$ of the sulfur to be recycled back to the claus process. The Alkazid plant removes $95 \%$ of the $\mathrm{H}_{2} \mathrm{~S}$ entering the raw gas, thereby satisfying emissions standards. The cleaned gas contains $238 \mathrm{ppm}$ by volume (dry) of $\mathrm{H}_{2} \mathrm{~S}$. A separate cleanup system reduces the sulfur emissions from the lock-hopper gas. Only $5.6 \%$ of the total sulfur is emitted to the atmosphere as $\mathrm{SO}_{2}$.

Alkazid is the trade name for a gas sweetening process using concentrated water solutions of salts of amino acids. The process which was developed in the 1930s in Germany, is now in the public domain. The sorbent is a solution of the potassium salt of diethyl glycine or dimethyl glycine. The amine group in the salt is basic and has a natural affinity for any gas that dissolves and forms an acid in water solution. $\mathrm{H}_{2} \mathrm{~S}$ forms acidic complexes in water so it is called acid gas, and forms a weak complex with the amine group in Alkazid.

About $95 \%$ of the incoming $\mathrm{H}_{2} \mathrm{~S}$ must be removed in the cleanup system. Towers operating in parallel are needed to accommodate the large volume of gas flow. Gas enters the bottom of each tower and leaves through the top. Fresh clean sorbent is added at the top of each tower, and loaded sorbent is withdrawn from the bottom of each tower. The liquid and gas flow countercurrent. During the absorption, both $\mathrm{H}_{2} \mathrm{~S}$ and $\mathrm{CO}_{2}$ are absorbed. However, the affinity of the sorbent for $\mathrm{H}_{2} \mathrm{~S}$ is about 28 times as great as for $\mathrm{CO}_{2}$.

The loaded sorbent from the absorption tower is regenerated by stripping out the $\mathrm{H}_{2} \mathrm{~S}$ and $\mathrm{CO}_{2}$ with an ascending current of water vapor. The stripper operates at a high temperature and a low pressure so that the vapor pressure of the acid gases leaving the solution is higher than the partial pressure of the acid gases in the vapor phases. This ensures that the acid gases leave the liquid phase and enter the gas phase. The best performance conditions for an absorber are at low temperature and high pressure whereby the acld gases tend to leave the gas phase and enter the liquid phase. The conditions for operating a stripper are the opposite of those for an absorber. 
The Claus plant converts $\mathrm{H}_{2} \mathrm{~S}$ in an acid gas into elemental sulfur.' Claus plants are standard packaged systems. Usually, they operate at $90 \%$ efficiency. That is, $5 \%$ of the entering sulfur remains unconverted and leaves as $\mathrm{H}_{2} \mathrm{~S}$ and $\mathrm{SO}_{2}$ in the tall gas. The tail gas is incinerated and scrubbed to remove most of this $\mathrm{SO}_{2}$ before it is emitted to the atmosphere. Part of the $\mathrm{SO}_{2}$ from the Wellman-Lord scrubber is recycled to the Claus plant. A third of the entering acid gas is incinerated with stoichiometric air to form $\mathrm{SO}_{2}$. The hot gases are cooled in a waste heat recovery boiler so that when they are mixed with the acid gas that was bypassed, the temperature will be around $450^{\circ} \mathrm{F}(505 \mathrm{~K})$. The mixed gases react with the reaction:

$$
2 \mathrm{H}_{2} \mathrm{~S}+\mathrm{SO}_{2} \rightarrow 3 \mathrm{~S}+2 \mathrm{H}_{2} \mathrm{O} \text {. }
$$

However, only part of the $\mathrm{H}_{2} \mathrm{~S}$ reacts in this way in the mixing environment without catalyst. The gas is cooled to condense the sulfur vapor thus formed; then it is passed through three successive cycles of reheating, reaction over catalyst, and cooling to condense liquid sulfur.

\subsection{CONTROL OF NO}

Nitrous oxides are formed by combustion of ammonia, and to a Iimited extent by oxidation of $\mathrm{N}_{2}$ gas diluent. To meet the emission standards, 0.34 $1 b$ of $\mathrm{NO}_{2}$ may be emitted to the atmosphere per $\mathrm{MBtu}$ of gaseous fuel. In other words, $3 \%$ of $\mathrm{NO}_{2}$ can be emitted and will indicate that $\mathrm{NH}_{3}$ removal equipment is needed. The product and lock-hopper gas is washed to reduce its $\mathrm{NH}_{3}$ content. The ammonia is removed for sale as a potential by-product. Attention must be paid to the design of the gas turbine combustion system to minimize the formation of $\mathrm{NO}_{x}$ by oxidation of atmospheric $\mathrm{N}_{2}$.

\subsection{CLEANUP OF PROCESS WATER SYSTEMS}

In the cleanup system, foul water condenses from the gas during dewaterIng. A foul process water enters with 011 and phenol from the gasifier washercoolers. These foul waters contain dissolved $\mathrm{H}_{2} \mathrm{~S}, \mathrm{NH}_{3}, \mathrm{CO}_{2}$, and phenols. The water separated from the oil and phenol is returned to the washer-coolers where some additional makeup water is located. This makeup vater evaporates and enters the cleanup systems with the saturated gas. In both cleanup systems, some heat must be added to the makeup water before it is sent to the washer coolers. 


\subsection{LIQUID WASTE}

Ammonia $\left(\mathrm{NH}_{3}\right)$ produced at the plant site would be stored in suitable tanks for regular removal by tank-car or by pipeline to potential users.

\subsection{SOLID WASTE}

Solid waste, mainly ash and other noncombustible products from the gasifler, is a major disposal problem. Th1s is complicated by the potential presence of hazardous materials in the ash. Thus, special care must be taken in disposing of the ash in a suitable fashion, to minimize the environmental impact. Separate facllities would be required to dispose of scrubber sludge by ponding. 'Suitable means would have to be found to prevent the sludge from diffusing into the ground, probably by lining the disposal area with an impermeable layer.

The sulfur recovered from the Claus plant may also be treated as solid waste, if it cannot be marketed.

\subsection{SPECIFIC DATA ON RESIDUAIS}

\subsubsection{Air Emissions}

These are the total emissions which determine the plants' compliance with the New Source Performance Standards for gas turbines. These may also limit plant siting under the criteria for the prevention of significant deterioration. Emissions are:

$$
\begin{array}{ll}
\mathrm{SO}_{2} & : 43.4 \text { tons/day } \\
\mathrm{NO}_{\mathrm{x}} & : 0.1 \text { tons/day } \\
\text { Particulates } & : 3.0 \text { tons/day }
\end{array}
$$

Gaseous emissions come both from the incinerator stack of the LBtu gas cleanup system and from the gas turbine combustion products discharged through the heat recovery steam gcnerators. The values for emissions given above are for nominal (1250 MWe) plant operation.

\subsubsection{Liquid Effluents}

Primary cooling water and blowdown $=2.50 \times 10^{6} \mathrm{gal} / \mathrm{day}$. 


\subsubsection{Solid Wastes}

Materials recovered from the process stream are:

Ash : 1240 tons/day

Sulfur : 359 tons/day

Ammonia : 108 tons/day

Sludge : 51 tons/day (tail gas cleanup)

The total waste heat dissipated by the palnt to the atmosphere is as follows:

Cooling Towers: $3.44 \times 10^{9} \mathrm{Btu} / \mathrm{hr}$

Stack : $2.58 \times 10^{9} \mathrm{Btu} / \mathrm{hr}$

TOTAL $\quad 6.02 \times 10^{9} \mathrm{Btu} / \mathrm{hr}$

\subsubsection{Land Use}

The plant requires a considerable amount of land for plant facilities and for waste disposal. The basic land requirements for this plant are as follows :

Plant Area : 132 acres

Waste Disposal over

a 30-Year Lifetime: 214 acres

TOTAL 346 acres

The actual plant site would be about 500 acres to provide room for expansion or changing needs over the plant's lifetime.

\subsubsection{Water Consimption}

Estimated value for water consumption is given in the table below:

$\begin{array}{cc}\text { Water, total ( } 10^{6} \text { gal/day) } & 12.48 \\ \text { Consumptlun: } & 7.62 \\ \text { Cooling tower evaporation } & 0.06 \\ \text { Steam system makeup } & 0.81 \\ \text { Gasifier process } & 1.26 \\ \text { Gas cleanup system } & 0.00 \\ \text { No suppression } & 0.30 \\ \text { "Hotel" usage } & 2.40 \\ \text { Blowdown treated waste: } & 0.03 \\ \text { Cooling tower blowdown } & \end{array}$


The total water demand of $0.416 \mathrm{gal} / \mathrm{kWh}$ is based on the following assumptions.

- Cooling water evaporation and drift losses amount to $102 \mathrm{gal} / \mathrm{MBtu}$ of heat rejected, and the blowdown losses are estimated to be $32 \mathrm{gal} / \mathrm{MBtu}$. The combined water loss from these two sources alone is $80 \%$ of total plant demand.

- Gasifier process water demand is in the form of water spray in the course coal train and water injection in the air blast; the latter is derived from the booster compressor drive turbine exhaust steam condensate and thus extracted from the steam cycle.

- Gas cleariup system water demand consists of process steam extracted from the steam cycle and process water flows. A small fraction of the consumed water leaves the cleanup system in the form of process blowdown.

- "Hotel" usage; taken at $3 \%$ of total water consumption, represents general plant use.

Key residuals are sumarized in Table 4-5.

Table 4-5. Summary of Flow of Major Residual Materials for Environmental Control System

\begin{tabular}{|l|c|}
\hline \multicolumn{1}{|c|}{ MATERIALS } & TONS/YEAR \\
\hline INPUTS & 7463 \\
IImestone & 811 \\
Sodium Carbonate & 14 \\
Anti Oxidant & 0.51 \\
Wellman-Lord Catalyst & \\
OUTPUTS & \\
Ash (from gasifier) & 317,060 \\
Elemental Sulfur & 91,725 \\
Sulfur Sludge & 18,629 \\
Ammonia (By-Product) & 27,594 \\
\hline
\end{tabular}




\subsection{CONSTRUCTION AND OPERATION CHARACTERISTICS}

\subsection{PERSONNEL REQUIREMENTS}

The normal construction period for a large coal-fired electric generation facility of the type characterized here would take a total of seven years. This includes a fairly low-level-of-effort period of two years for site selection, design, and preparation, and a five year period of actual on-site construction. During the on-site construction period, an estimated 8.1 million man-hours of direct craft labor would be required.

The direct craft labor employment figures do not include various inhouse utility and consultant man-hours which are considered indirect labor requirements by the utility for capital costing purposes. The magnitude of these indirect labor requirements, however, is somewhat less than the direct craft requirements.

Since this technology is new, and until regular routines are developed, additional time may be required for construction, testing, and start-up. Detailed labor breakdowns are not available for this technology.

Operating personnel requirements for this plant can only be roughly estimated from similar requirements for conventional plants. An estimated personnel requirement is shown in Table 4-6. Detailed breakdowns of their activities would be similar to other coal-fired systems. From time to time, additional maintenance staff would be required to complete major scheduled or unscheduled emergency repairs on the turbine system, boller, environmental control system, or other major plant components.

\subsection{OPERATING STATISTICS AND ANNUAL GENERATION}

Historlcal statistics on large coal-fired electric generation facilities of this type indicate that the overall plant capacity factor would be in the neighborhood of $70 \%$, which has been used throughout this characterization. In other words, the plant would produce $70 \%$ of the maximum possible kilowatthours it could generate if it were operated continuously at full capacity. 
Table 4-6. Direct Labor Summary for Operation of Reference 1250

MW Coal Gasification Facility/Combined Cycle (2 Units)*

\begin{tabular}{|c|c|c|}
\hline OPERATING PERSONNEL & $\begin{array}{l}\text { NUMBER OF } \\
\text { PERSONNEL }\end{array}$ & $\begin{array}{l}\text { THOUSAND } \\
\text { MAN-HOURS/ } \\
\text { YEAR } \\
\end{array}$ \\
\hline \multicolumn{3}{|l|}{ Plant Managers Office } \\
\hline $\begin{array}{l}\text { Manager } \\
\text { Assistant } \\
\text { Environmental Control } \\
\text { Public Relations } \\
\text { Training } \\
\text { Safety } \\
\text { Administrative Services } \\
\text { Health Services } \\
\text { Security }\end{array}$ & $\begin{array}{r}1 \\
2 \\
1 \\
1 \\
1 \\
1 \\
14 \\
1 \\
7 \\
\end{array}$ & $\begin{array}{r}2 \\
4 \\
2 \\
2 \\
2 \\
2 \\
28 \\
2 \\
14 \\
\end{array}$ \\
\hline SUBTOTAL & 29 & 58 \\
\hline \multicolumn{3}{|l|}{ Operations } \\
\hline $\begin{array}{l}\text { Supervision } \\
\text { Shifts } \\
\text { Fuels and Materials Handilng } \\
\text { Waste Systems }\end{array}$ & $\begin{array}{r}3 \\
50 \\
12 \\
30 \\
\end{array}$ & $\begin{array}{r}6 \\
100 \\
24 \\
60 \\
\end{array}$ \\
\hline SUBTOTAL & 95 & 190 \\
\hline \multicolumn{3}{|l|}{ Maintenance } \\
\hline $\begin{array}{l}\text { Supervision } \\
\text { Crafts } \\
\text { Peak Maintenance Annualized }\end{array}$ & $\begin{array}{r}8 \\
115 \\
66 \\
\end{array}$ & $\begin{array}{r}16 \\
230 \\
132 \\
\end{array}$ \\
\hline SUBTOTAL & 189 & 378 \\
\hline \multicolumn{3}{|l|}{ Technical and Engineering } \\
\hline $\begin{array}{l}\text { Waste } \\
\text { Radiochemical } \\
\text { Instrumentation \& Control } \\
\text { Performance, Reports and } \\
\text { Technicians }\end{array}$ & $\begin{array}{r}2 \\
2 \\
2 \\
17 \\
\end{array}$ & $\begin{array}{r}4 \\
4 \\
4 \\
34 \\
\end{array}$ \\
\hline SUBTOTAL & 23 & 46 \\
\hline TOTAL & 336 & 672 \\
\hline
\end{tabular}

* Adapted from Operating Staff requirements for 2 unit coal facilities, 400 MWe - 700 MWe with FGD

t 572 persons for 6 weeks $=3,432$ person weeks -52 weeks $/ y r=66$ persons annualized 
Numerous parameters combine to produce this factor. Namely, these include plant down-time for scheduled maintenance, plant forced outage rate due to unexpected component failure, and the customer load profile (including interutility sales of electricity). The first two factors combine to determine plant availability, while the inclusion of customer demand results in the plant capacity factor.

Typically, a large coal-fired station, such as the type characterized here, would be placed early in the utility's loading order. Thus, it would hardly be affected by the nustomer's dcmand since it would serve to satisfy part of the minimum customer load. However, a factor of 0.97 has been applied to the calculated plant availability to simulate a small reduction in plant operation.

Scheduled maintenance for large coal facilities with flue gas desulfurization systems vary between 4 to 8 wecks/year, and forced outage rates range from 10 to $15 \%$. Here, the larger or more conservative values have been selected for the reference facility. Thus, plant availability is determined by:

$$
\text { Plant Availab1lity }=\left(\frac{52-8}{52}\right) \times(1-0.15) \times 100 \%=72 \%
$$

Adjusting for customer demand reduction results in:

$$
\text { Capacity Factor }=(72 \%)(.97)=70 \%
$$

At this capacity factor, the reference 1250 WWe high-sulfur coal facility. would generate $7.665 \times 10^{9}$ kilowatt-hours/year. However, actual operating experience is lacking with combined cycle systems. For new plainls, capaclty factors are likely to be lower, until plant reliabllity is improved and operating practices consolidated.

\subsection{GASIFIER REQUIREMENTS}

The plant has to be designed with a sufficient number of gasifiers so low Btu-gas and electrical energy production can be maintained, even during individual or multiple outages of gasifier modules. This aystem is deslgned with additional gasifiers that serve as backups. This raises the overall system availability. The methodology and design calculations are sumarized in Table 4-7. 
Table 4-7. Summary of Gasifier Availability Analysis

$$
\text { Gasifier Availability }=\sum_{x}^{x} \sum_{=1}^{=m} P(x) \frac{x}{m}
$$

where $P(x)$ = probability $x$ gasifiers are operating

$m$ = total gasifiers needed for plant operation

$$
P(x)=\left(\frac{n}{x}\right) p^{x}(1-p)^{n-x}
$$

where $n=$ the total number of units

$p=$ probability any one unit is working $=1-q$

$q=$ outage rate

Design Example -
Operating units $(\mathrm{m})=13$
Total units $(\mathrm{n})=16$
Outage rate $(q)=0.20$
Avallability
$=94.4 \%$ 


\subsection{COST CHARACTERIZATION (CG/CC)}

Capital cost estimates for the 1250 MWe reference coal gasification combined cycle generation facility have been derived primarily from cost data presented in the ECAS report, which also served as the basis for the technological characterization developed in the previous sections. The ECAS report estimates direct capital costs (in 1975 dollars) and labor requirements for a 579 MWe single unit facility which is similar in design to the referencc system. The ECAS study, however, assumed the use of coal. feed with oomewhal different proporticg thall is assumed here. In addition, the study assumed more stringent environmental controls that are required on a facility of this type. The proreriures which are used ro adapt the ECAS direct cost estimates reflect the reference coal gasification combined cycle facility design parameters and are discussed in the fullowing section.

To ensure consistency with the cost estimates for the other technologies, indirect costs were derived from data on a $630 \mathrm{MWe}$ coal gasification. This data was presented in the Energy Economic Data Base (EEDB). Before selecting these costs, the data costs and the labor requirements for an alternativc ECAS coal gasification combined cycle facility were compared to those costs of the similar EEDB plant. Both plants were designed to meet the solld fuels emission standards. After correcting the differences in the dollar value of the estimates and plant capacities, these costs and labor requirements were found to be very similar. "This similarity thus supports the use of the EEDB indirect costs for the reference system.

\subsection{DIRECT CAPITAL COSTS}

The ECAS direct capital costs are estimated in 1975 dollars for a single unit (579 MWe coal gasification combined cycle facility). The costs have been appropriately adjustcd to rellect major design and performance characteristics assumed for the reference facility which is composed of two 625 MWe units on one plant site. In particular, the design and performance modifications

Actually, substantial differences in costs were displayed for some individual accounts due primarlly to different gasifier vessel designs and other factors. The "bottom line" costs, however, differed by only a few percent and labor requirements were nearly identical. 
assumed for the reference system, that measurably affect the facility's direct capital ensts; are eummarized below:

- Feed coal characteristics used in the ECAS study (10788 Btu/1b, $3.9 \%$ sulfur, $9.6 \%$ ash and $59.6 \%$ carbon) have been modified to be consistent with the coal characteristics assumed in the conventional coal combustion reference system (11026 Btu/1b, 3.2\% sulfur, $10.29 \%$ ash and $61.49 \%$ carbon). This modification results in a $3 \%$ decrease in coal feed throughput and a $5 \%$ increase in ash throughput to produce the same quantity of low Btu gas.

- Air emission standards used in the ECAS study assume $\mathrm{SO}_{2}$ and $\mathrm{NO}_{\mathrm{x}}$ limits of $0.2 \mathrm{lb} / 106 \mathrm{Btu}$ of gas fired! Recent regulations promulgated by the EPA specify that gas turbine emission standards apply to a facility of this type. These emission limits are 150 ppm of $\mathrm{SO}_{2}$ and $75 \mathrm{ppm}$ of $\mathrm{NO}_{\mathrm{x}}$ by volume in the turbine exhaust gas stream at $15 \%$ oxygen. These standards are approximately equivalent to $.471 \mathrm{~b} / 10^{6} \mathrm{Btu}$ of gas fired for $\mathrm{SO}_{2}$ and $.341 \mathrm{~b} / 106$ of gas for $\mathrm{NO}_{\mathrm{x}}$. The current standards are easily met by the gas cleanup equipment installed on the reference facility. Thus, the only modification made to the ECAS design was to reduce the cleanup equipment installed on the reference facility. Thus, the only modification made to the ECAS design was to reduce the cleanup equipment collection efficlencles ranging from 95 to $98.5 \%$ to more achievable values ranging from 90 to $95 \%$. These efficiencies are consistent with the assumptions related to the conventional coal facility. The result is emission levels below the applicable standard. The combined effect of this modification, coupled with the difference in coal characteristics, is to reduce the residual's loading on the gas cleanup equipment by approximately $20 \%$ for the same quantity of low Btu gas.

Overall unit capacity was increased from 579 MWe assumed in the ECAS study to $625 \mathrm{MWe}$, a $7.9 \%$ increase in major plant flows and generation output. This modification resulted in the requirement of an additional operating gasifier (1.3 rather than 12) to achieve full capacity output while maintaining the unit gasifier vessel ash throughput within the design range spectfied in the ECAS study. A parametric analysis of the gasifier module rellability indlcated that an additional standby gasifier would substantially decrease the module forced outage rate. Thus, three rather than two standby vessels have been assumed. In total, 16 vessels are assumed for each unit in the reference system (32 vessels in the two-unit plant) as compared to 14 vessels per unit in the ECAS design.

- The reference system capacity of 1250 MWe is assumed to be achieved by a two unit plant, each unit generating 625 MWe at full capacity. Although design limitations would require major equipment pieces to be independent, such systems as site structures and improvements, some fuel and residuals handling equipment can be shared by the two units. As a result, a detailed cost estimate indicates a $9 \%$ cost savings on the second unit. 
Base direct capital costs include the cost of all materials, components, equipment, structures, and associated craft labor necessary to construct the reference facility at the plant site. Delivered costs for materials and equipment are used. Base indirect costs include site temporary construction facilities, payroll insurance and taxes, and other home and field office expenses. Specifically excluded from the base construction cost estimate are several items that are sensitive to the particular policies and preferences of the individual utility and to the specific plant site and prevalling economic factors being considered. Thesc exclusions are identified in the following list of items:

$$
\begin{aligned}
& \text { Owner's Costs - Consultants, Site Selection, etc. } \\
& \text { - Federal, State and Local fees, Permits and l'axes } \\
& \text { - Interest on capital Construction Funds } \\
& \text { - Price Escalation During Construction } \\
& \text { - Contingency Funds }
\end{aligned}
$$

- Owner's Discretionary Items - Switchyard and Transmission Costs, Waste Disposal Costs, Spare Parts, and Initial Fuel Supplies

The methodology and procedure applied to estimate the direct capital costs for the 1250 MWe reference coal gasfilcation comblned cycle system was to review the detalled cost cotimates made tn the ECAS report for the 579 MWe design and, where appropriate, adjust the costs using a capacity or loading ratio estimating relationship. This technique, which is generally accepted by the electric power generation industry for making cose estluate modifications of similar systems or subsystems, uses the following equetion to adjust component capital costs to different levels of capactity or loading' Cost or Component $B=$ Cost of Component $A \times\left(\frac{\text { Capacity of } B}{\text { Sapacity of } A}\right)^{\alpha}$

where components $A$ and $B$ are of similar design, differing only in size, capacity, or loading, and where the exponent $(\alpha)$ depends on the type of system or component being considered. The exponent values ueed in estimating the costs of the coal gasification combined cycle reference system components are similar to those used in estimating the costs for the reference coal combustion facility. Due to the unique nature of the ECAS code of accounts, - however, it was necessary to apply the cost estimating exponents to individual 
equipment items to ensure consistency with other technology cost estimates derived from the Energy Economic Data Base code of accounts. Thus, it was first necessary to identify the applicable EEDB coal system account for each ECAS equipment item and then assign the appropriate cost estimating exponent. Where no direct parallel of equipment type existed, basic design similarities were taken into consideration (e.g., tank, vessel, pump, turbine) before assigning an appropriate cost estimating exponent. Details of this and results of the following procedural steps are shown in the Appendix. Table 4-8 summarizes the original ECAS 579 MWe facility costs corrected to January 1, 1978 dollars and also shows the final direct capital cost estimates for the two unit reference 1250 MWe coal gasification combined cycle facility.

As explained further in the Appendix, the reference system direct capital costs were derived by application of the following procedural steps:

- A detalled equipment and cost 1ist for the original ECAS 579 MWe plant using Illinois No. 6 coal (10788 Btu/lb, 3.9\% sulfur, $9.6 \%$ ash, and $59.6 \%$ carbon) was compiled and appropriate cost estimating exponents consistent with the EEDB conventional coal system were assigned as indicated above.

- Using these cost estimating exponents, costs were modified to reflect: (1) the use of the Eastern Interior coal used in the conventional coal characterization $(11,026 \mathrm{Btu} / 1 \mathrm{~b}, 3.2 \%$ sulfur, $10.29 \%$ ash, $61.49 \%$ carbon) and (2) the decrease in loadings and collection efficienctes on pollution control equipment. The latter results from the different coal and applicable emission standards not enacted prior to the ECAS design. No modification was made to the system's gas production rate or generation capacity at this step.

- After correcting for coal characteristics and environmental regulations, the system was sized to a net output of $625 \mathrm{MWe}$. Two additional gasifier vessels were required at this step (+ 1 operating, +1 standby, for a total of 16) to meet the ash throughput design limitation for each vessel and to ensure reliable operation. Since no modification was made to the vessel itself, these additional vessels were not costed using an exponent technique, but rather were added at their given unit costs. A separate account lists additional piping. 
Table 4-8. Estimated Direct Capital Costs for Two Un1t 1250 MWe Reference Coal Gasification Combined Cycle Facility (January 1, 1978 Dollars)

\begin{tabular}{|c|c|c|c|c|c|}
\hline \multirow{2}{*}{ Account $(a)$} & \multirow[b]{2}{*}{ Description $(a)$} & \multirow{2}{*}{$\begin{array}{l}579 \text { MWe } \\
\text { ECAS DESIGN COST } \\
(\$ 1000)\end{array}$} & \multicolumn{3}{|c|}{ 125i MNe Reference Design Costs $(\$ 1000)$} \\
\hline & & & Unte 1 & Unit 2 & Total \\
\hline 20 & Land and Land RIghts & (b) & $1,120^{(c)}$ & $1,120^{(c)}$ & $2,240^{(c)}$ \\
\hline 21 & Structures and Improvements & 13,138 & 13,344 & 12,011 & 25,355 \\
\hline 22 & $\begin{array}{l}\text { Coal Hardling, Gasification } \\
\text { Cleanep }\end{array}$ & 88,960 & 89,789 & 74,343 & 164,132 \\
\hline 23 & $\begin{array}{l}\text { Frime (Gas Turbine) Cycle } \\
\text { Equipment }\end{array}$ & 37,016 & 37.016 & 37,016 & 74,032 \\
\hline 24 & $\begin{array}{l}\text { Bottom (Steam Turbine) } \\
\text { Cycle Eq }=1 \text { pment }\end{array}$ & 29,180 & 30,867 & 30,867 & 61,734 \\
\hline 25 & Electric Plant Equipment & 15,234 & 15,469 & 15,469 & 30,938 \\
\hline & TOTAL DIRECT EQUIPMENT & 183,528 & 187,505 & 170,826 & 358,431 \\
\hline & SITE LABOR COSTS & 93,660 & 93,660 & 85,283 & 178,943 \\
\hline & $\begin{array}{l}\text { TOTAL DIRECT BASE } \\
\text { CONSTRUCTION COSTS }\end{array}$ & 277,188 & 281,265 & 256,109 & $537,3.74$ \\
\hline
\end{tabular}

(a) Miscellaneous equipment and condenser haat rejection sqstem costs inciuded in accounts 21,22, and 23.

(b) Land costs not specified, ECAS assumed approximately 65 acre site.

(c) Assumes 500 acres at 4480 \$/acre assigned equally to each untt. 
- Estimates were then made on a component by component basis of the incremental cost of adding a second 625 MWe unit on the same site, sharing appropriate facilities. In some cases, (e.g., coal handling equipment) that portion of the equipment cost assignable directly to the individual unit's gasification or power production module was not considered as shared equipment, while the coal yard equipment or other plant structures were considered shared. The applicable relationship for the incremental, second unit cost for independent and shared facilities are given by the following when identical capacities or loadings are required for each unit:

$$
\begin{aligned}
& \text { Independent Equipment: } U_{2}=U_{1} \\
& \text { Shared Equipment: } \quad U_{2}=\left(2^{\alpha}-1\right) U_{1} \\
& \text { where, } U_{1}=\text { Unit } 1 \text { cost } \\
& U_{2}=\text { Unit } 2 \text { incremental Cost } \\
& \alpha=\text { applicable cost estimating exponent }
\end{aligned}
$$

Land costs were divided equally among the two units.

- Each of the resultant costs was then escalated to January 1, 1978 dollars from their original estimate in mid-1975 dollars by applying the corresponding GNP price deflator index ratio of 1.1365 .

- Craft labor requirements for Unit 1 were taken to be identical to those associated with the original 579 MWe ECAS design which were also the same as those for the 630 MWe EEDB design, $7 \times 106$ manhours. Craft labor costs for Unit 2 were taken to be proportional to the equipment and materials costs which result from the use of shared facilities and site labor learning associated with construction of the previous identical unit. Labor costs were taken to be consistent with the average labor cost estimated in the EEDB, or $\$ 13.38 /$ hour. The indirect labor cose account indicates indirect labor costs.

\subsection{INDIRECT CAPITAL COSTS}

To ensure consistency across technologies, the indirect capital construction costs associated with reference coal gasification combined cycle facility were derived from the indirect costs associated with the combined cycle facility used in the Energy Economic Data Base. Indirect capital costs assoctated with the construction of large electric generation facilities are relatively insensitive to the range of untt capacities considered here. Therefore, the indirect capital costs for: the first unit of the reference system coal gasification combined eycle facllity are taken to be identical to the corresponding EEDB indirect costs. As various cost reductions are 
achievable when constructing identically designed units in a continuous operation at the same plant site, the indirect costs associated with the second unit are estimated to be proportional to the ratio of direct construction costs. Thus, indirect capital costs (summarized in Table 4-9) total $\$ 132,717,000$.

Table 4-9. Estimated Indirect Capital Costs for 1250 MWe Coal Gasification Combined Cycle Reference System (January 1, 1978 Dollars)

\begin{tabular}{|c|c|c|c|c|}
\hline \multirow[b]{2}{*}{ ACCOUNT } & \multirow[b]{2}{*}{ DESCRIPTION } & \multicolumn{3}{|c|}{ Reference Design Costs $(\$ 1000)$} \\
\hline & & Unit 1 & Unit 2 & TOTAL \\
\hline 91 & Construction Services & 42,205 & 33,430 & 80,635 \\
\hline 92 & $\begin{array}{l}\text { Home Office Engineering } \\
\text { and Services }\end{array}$ & 15,355 & 13,982 & 29,337 \\
\hline 93 & $\begin{array}{l}\text { Field Office Engineering } \\
\text { and Services }\end{array}$ & 11,905 & 10,840 & 22,745 \\
\hline & TOTAI INDIRECT COSTS & 69,465 & 63,252 & 132,717 \\
\hline
\end{tabular}

\subsection{OPERATION AND MAINTENANCE COSTS}

Annual operation and maintenaice (OSM) costo for the 1250 MWe referenle coal gasification combined cycle facility have been estimated, based on cost estimating relationships in a recent Oak Ridge National Laboratory (ORNL) document entitled, "A Procedure for Estimating Non-Fuel Operation and Maintenance Costs for Large Steam Electric Fower Plonte," and on dat.a available in the Energy Economic Data Base'. In general, the O\&M cost components used here have been adapted from cost estimates of large, conventional coal combuetion facilities. As was previously the case with the conventional coal reference system, the O\&M costs have been supplemented with EPA data on Wellman-Lord flue gas desulfurization O\&M costs.

Generally, O\&M costs consist of six cost categories and may be either flxed costs, not dependent on annual generation, or variable costs which are proportional to generation level. The six cost categories considered here include: plant staffing, maintenance materials, plant supplies and expenses, environmental controls, interim replacements, and administrative and general expenses. 
Plant staffing costs are based on an estimated 336 person plant staff described earlier and assumes an average cost of $\$ 22,000$ per person per year, or about $\$ 11 /$ man-hour. Maintenance materials costs are assumed to follow the same relationship as coal plant costs averaging $82 \%$ of the maintenance staff costs ( 189 persons) for facilities with flue gas desulfurization; $62 \%$ being fixed expenses and $20 \%$ representing a maximum level variable expense at a plant capacity factor of $80 \%$. Fixed and variable supplies and contract expenses are difficult to estimate because there is little data available on coal gasification combined cycle facilities. Expenses can be anticipated to be somewhat higher than a conventional coal plant due to the added system complexity. For this reason, fixed and variable supply and expense costs for the reference coal gasification combined cycle facility are estimated to be $60 \%$ higher than the corresponding costs of a conventional coal generation system. Thus, the fixed supplies and expenses are estimated $.08 \mathrm{mills} / \mathrm{kWh}$. Administrative, overhead, and utillty home office general expenses associated with the reference facility are estimated to be $10 \%$ of the staff costs and fixed components of the materials, supplies, and expenses costs.

Operations and maintenance costs for environmental controls are based primarily on the ash, elemental sulfur, dry sodium sulfite/sulfate disposal costs of $\$ 4 /$ ton for remote site disposal. Disposal costs for the wet lime scrubber sludge is estimated at \$10/ton. A land area of 7.1 acres per year at $\$ 4,480$ per acre has also been included in the environmental controls O\&M cost estimate. Feed materials, such as 1Ime, sodium carbonate, catalyst and an antioxidant required to operate the environmental control systems are also included as part of this cost estimate.

Annual costs for Interim replacements of major capital items have been added to the $O \& M$ cost estimates. These were conservatively estimated to be $30 \%$ of the direct and Indirect capital costs for interim replacements over the total plant capital costs $(0.53 \%$ of total plant cost), and are charged to $0 \& M$ each year.

Table 4-10 details the annual O\&M costs estimated for the reference coal gasification combined cycle system. At the $70 \%$ capacity factor assumed for this system, annual O\&M costs total $\$ 20.66$ million or 2.70 mills $/ \mathrm{kWh} ; 2.22$ $\mathrm{mills} / \mathrm{kWh}$ are fixed costs, while $0.48 \mathrm{mllls} / \mathrm{kWh}$ are variable with plant generation. 
Table 4-10. Annual Operation and Maintenance Costs--1250 MWe Reference Coal Gasification Combined Cycle Facility at 70\% Capacity Factor

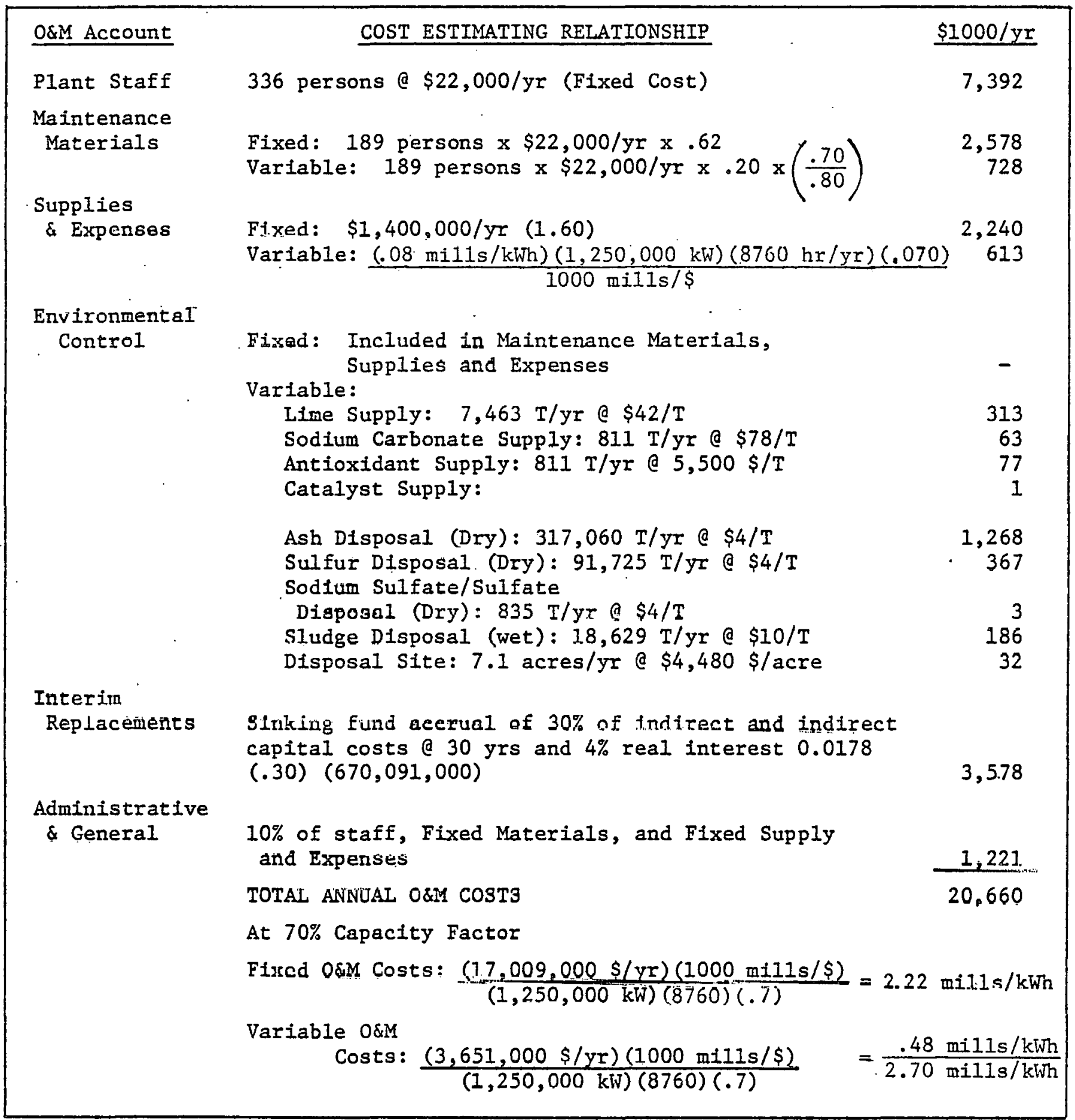


These costs compare with $2.69 \mathrm{mills} / \mathrm{kWh}$ for the conventional coal generation facility which is 1.66 mills/kWh fixed O\&M costs and 1.03 mills/kWh variable costs at the $70 \%$ capacity factor. 
This section summarizes the mining and supply of coal to various types of coal burning plants. The actual amount of coal delivered will depend on the plant's heat rate.

The base case considered is a mine in the Eastern coal region. The coal cycle flow diagram is presented in Figure $4-4$ based on a requirement for 1000 tons of coal delivered.

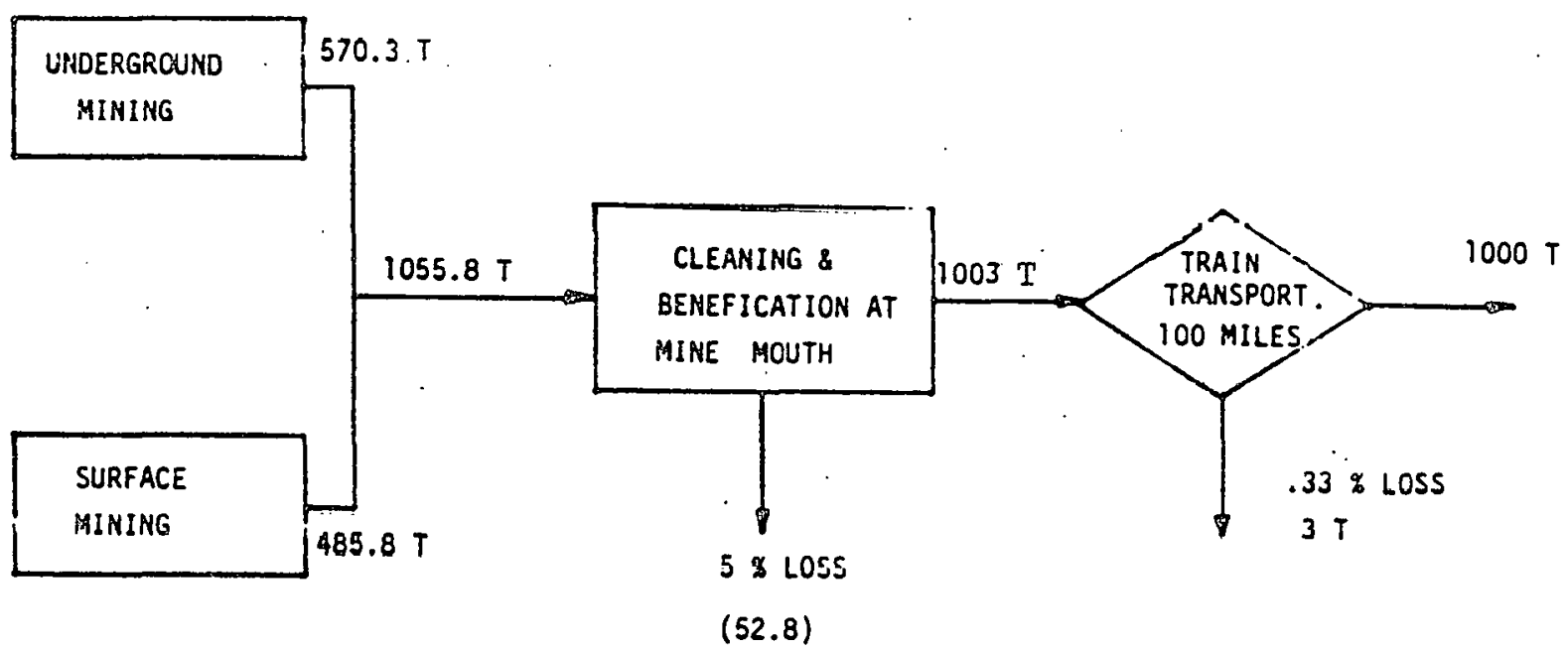

Figure 4-4. Coal Mining Cycle Summary

Each of the four stages involves processing and handling of the coal in different ways. The result is a series of diverse environmental impacts discussed in the following sections. 


\subsection{AIR EMISSIONS}

\subsubsection{Mining}

Surface mining produces the following air pollution effects:

- Particulate emissions occur as a result of blasting, digging, and road usage. The emissions from blasting and digging are not controllable. Water spraying and other dust control techniques at transfer points on roadways can reduce particulate, emissions by about 80 percent.

- Other emissions occur on an intermittent basis (NO from blasting) and continually ( $\mathrm{SO}_{x}, \mathrm{NO}_{x}$, and $\mathrm{CO}$ ) from the operation of diesel equipment. In large mining operations, the major excavating equipment is normally electrically driven so there are no direct equipment-related emissions.

Underground mining produces the following air pollution effects:

- Particulate emissions occur as a result of conventional mining (drill, load, and blast on an intermittent basis), and on an uninterrupted basis from the use of the continuous miner (the rotating drum cutters). Since mine health and safety laws require the air in the work areas to have particulate concentrations below $2 \mathrm{mg} / \mathrm{m}^{3}$, most particulates are dumped into the ventilation system where the majority drop out in the circuitous path that the exhausted air follows. There is evidence (i.e., snow at the ventilation exhaust exits of mines) that some particulates escape to the atmosphere.

- Other emissions occur on an intermittent basis if conventional mining is utilized, e.g., No from blasting. Otherwise, no direct emissions occur since ${ }^{x}$ underground coal mining equipment is normally electrically driven.

Air emission factors for surface wintng are given in lable 4-11. Air emissions for underground mining are negligible.

\subsubsection{Preparation}

Improved dust control in mines has resulted in wetter run-of-mine (ROM) coals; subsequently less fugilive partlculate emissions during handing operations prior to and during coal cleaning. However, there is no Federal regulation to control the emission source of fugitive dust from coal storage piles. In addition, refuse disposal piles may contribute fugitive dust as well as smoke, $\mathrm{SO}_{\mathrm{x}}, \mathrm{NO}_{\mathrm{x}}, \mathrm{H}_{2} \mathrm{~S}$, and $\mathrm{CO}$ during burning that follows spontaneous combustion. 
Thermal drying processes are used to dry the cleaned coal and make it suitable for transportation and combustion. The EPA's New Source Performance Standards (NSPS) for coal preparation plants regulates the discharge of particulate materials from thermal dryers to 0.031 grains per dry standard cubic foot. This further limits the amount of particulate emissions contributed by the preparation stage of the coal fuel cycle. Nevertheless, thermal dryers still contribute $\mathrm{SO}_{\mathrm{x}}$, $\mathrm{NO}_{\mathrm{x}}, \mathrm{HC}$, and $\mathrm{CO}$.

Table 4-11. Coal Mining Alr Emissions Factors for Surface Mining(a)

\begin{tabular}{|c|c|}
\hline POLIUTANT & TONS/DAY ${ }^{(\mathrm{b})}$ \\
\hline \multicolumn{2}{|l|}{ Particulates } \\
\hline $\begin{array}{l}\text { Uncontrolled and } \\
\text { Controlled }\end{array}$ & $\begin{array}{l}0.01 \\
0.01\end{array}$ \\
\hline \multicolumn{2}{|l|}{ Sulfur Oxides } \\
\hline $\begin{array}{l}\text { Uncontrolled and } \\
\text { Controlled }\end{array}$ & 0.02 \\
\hline \multicolumn{2}{|l|}{ Nitrogen Oxides } \\
\hline $\begin{array}{l}\text { Uncontrolled and } \\
\text { Controlled }\end{array}$ & 0.28 \\
\hline \multicolumn{2}{|l|}{ Carbon Monoxide } \\
\hline $\begin{array}{l}\text { Uncontrolled and } \\
\text { Controlled }\end{array}$ & 0.18 \\
\hline \multicolumn{2}{|l|}{ Hydrocarbons } \\
\hline $\begin{array}{l}\text { Uncontrolled and } \\
\text { Controlled }\end{array}$ & 0.028 \\
\hline \multicolumn{2}{|l|}{ Aldehydes } \\
\hline $\begin{array}{l}\text { Uncontrolled and } \\
\text { Controlled }\end{array}$ & 0.00 \\
\hline
\end{tabular}

(a) All surface coal is assumed to be moved by truck within the mine itself, No control techniques are assumed to be used to rontrol fugitive dust.

(b) At nominal (1250 MWe) power plant operation.

NOTE: Air emissions from underground mining are negligible. 
A sumary of emissions from the coal preparation process is given in Table 4-12.

Table 4-12. Coal Preparation Air Emission Factors

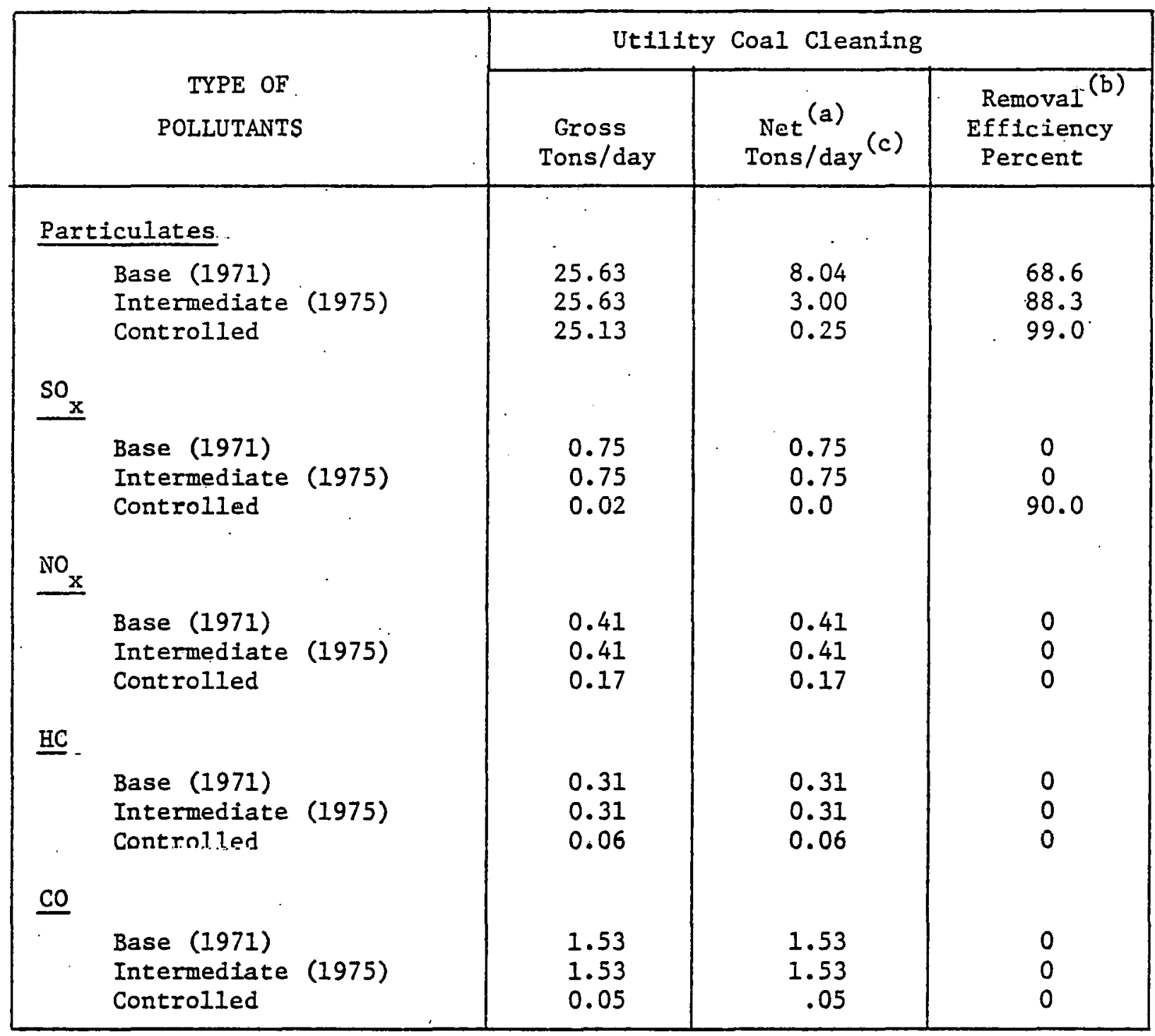

(a) Net refers to emissions subject to environmental controls.

(b) Composite over the entire cleaning process. Note that gross coefficients decline over time because of reclamation of refuse banks.

(c) For nominal (1250 MWe) power plant operation. 


\subsubsection{Transportation}

Each transportation mode has its own characteristic significant contribution to air quality degradation. Trucks produce the greatest air pollution/ ton mile within a given distance, whereas closed pipeline systems produce only a small amount of direct emissions. Trucks however, account for only a small portion (10.7\%) of the total ton-mile. In the example case, coal is assumed to be transported by train.

The air emissions for coal transportation for 100 miles are summarized in Table 4-13.

Table 4-13. Coal Transportation Air Emission Factors (Tons/Day)*

\begin{tabular}{|l|c|c|c|c|}
\hline \multirow{2}{*}{ POLLUTANT } & \multicolumn{4}{|c|}{ TRANSPORTATION TYPE } \\
\cline { 2 - 5 } & Unit Train & Mixed Train & RIVer Barge & Truck \\
\hline Tarê1culateo & 2.07 & 3.95 & 1.95 & 56. \\
Sulfur Dioxide & 0.38 & 0.30 & 0.08 & 0.31 \\
Nitrogen Oxides & 0.42 & 0.35 & 0.08 & 4. \\
Carbon Monoxide & 0.41 & 0.32 & 0.06 & 2.55 \\
Hydrocarbnns & 0.29 & 0.23 & 0.05 & 0.41 \\
Aldehydes & 0.06 & 0.05 & 0.00 & 0.07 \\
\hline
\end{tabular}

$\star$

For nominal 1250 MWe plant operation. 


\subsection{LIQUID EFFLUENTS}

\subsubsection{Mining}

The primary contribution to liquid effluent is acid mine drainage. A description of waste water effluent for Federal Region 5 is given in Table 4-14.

$$
\begin{aligned}
& \text { Table 4-14. Coal Mining Wastewater Effluents } \\
& \text { (Tons/day) }
\end{aligned}
$$

\begin{tabular}{|l|c|c|}
\hline \multicolumn{1}{|c|}{ POLLUTANT - } & $\begin{array}{c}\text { SURFACE } \\
\text { MINING }\end{array}$ & $\begin{array}{c}\text { UNDERGROUND } \\
\text { Total Iron }\end{array}$ \\
Suspended Iron & 0.43 & 0.42 \\
Dissolved Iron & 0.02 & 0.10 \\
Manganese & 0.42 & 0.31 \\
Aluminum & 0.37 & 0.01 \\
Zinc & 0.58 & 0.05 \\
Nickel & 0.01 & 0.00 \\
Total Dissolved Solids & 0.00 & 0.00 \\
Total Suspended Solids & 32.93 & 5.65 \\
Hardness & 4.45 & 0.27 \\
Sulfate & 15.77 & 1.45 \\
Ammia & 14.94 & 2.82 \\
Strontium & -0.05 & 0.01 \\
Chloride & - & 0.0 \\
Fluoride & - & 0.12 \\
\hline
\end{tabular}

For nominal (1250 MWe) power plant operation 


\subsubsection{Preparation}

Currently, many coal preparation plants are operating with a closed water circuit and, as a result, normally discharge little or no process water. Further, drainage from coal storage piles and refuse areas can be collected and treated, thereby reducing the aquatic loadings from coal preparation plants. The characteristics of liquid effluents from coal preparation are described in Table 4-15 for refuse pile runoff. In each case, the net discharge is essentially zero.

Table 4-15. Coal Cleaning Wastewater Effluents Refuse Pile Run-Off* (Tons/day) $(t)$

\begin{tabular}{|c|c|c|c|}
\hline WASTEWATER - EFFLUENTS & $\begin{array}{l}\text { Gross-Untreated Process } \\
\text { Water Refuse Pile Run-off }\end{array}$ & $\begin{array}{r}\text { Net }(*) \\
\text { Discharge }\end{array}$ & $\begin{array}{l}\text { Removal }^{(\dagger+)} \\
\text { Efficiency }\end{array}$ \\
\hline Total Iron & 2.99 & 0.00 & 99.9 \\
\hline Suspended. Iron & 2.97 & 0.00 & 99.9 \\
\hline Dissolved Iron & 0.02 & 0 & 98.3 \\
\hline Manganese & 0.07 & 0.00 & 95.4 \\
\hline Aluminum & 0.28 & 0 & 100 \\
\hline Zinc & 0.01 & 0 & 100 \\
\hline Nickel & 0.0 & 0 & 100 \\
\hline Total Dissolved Solids & 37.65 & 0 & 100 \\
\hline Total Suspended Solids & 1648.05 & 0.02 & 99.9 \\
\hline Hardness & 40.46 & 0 & 100 \\
\hline Sulfates & 26.38 & 0 & 100 \\
\hline Ammonia & 0.05 & 0 & 100 \\
\hline
\end{tabular}

(*) These residuals pertain only to the refuse pile run-off, since the cleaning plant itself is assumed to employ closed water circuits to meet zero discharge.

(t) For nominal ( $1250 \mathrm{MWe}$ ) power plant operation

(t+) On Refuse Pile Run-off, using Best Available Technology 


\subsubsection{Transportation}

The primary liquid effluents in transportation of coal will come from coal slurry through pipelines. However, in the baseline case (1250 MWe plant) the coal is assumed to be transported by train from an Eastern coal region mine to a power plant located 100 miles away. Under these assumptions, negligible effluents result.

\subsection{SOLID WASTE}

\subsubsection{Mining}

Table 4-16 lists the estimates of solid waste from mining operations. For surface (strip) mining, this waste is primarily an overburden from initial excavation. For underground mining, the primary contributor to solid waste is the residual from treating mine water.

Table 4-16. Mining Solid Waste Effluents

\begin{tabular}{|c|c|}
\hline TOTAL SOLID WASTES & TONS/DAY OUTPUT* \\
\hline Underground Mining & \\
\hline $1971 \&$ \&. $1975 \cdots$ \\
1985 (projected) & 256 \\
Surface Mining & 356 \\
\hline $1971 \& 1975 \quad$ & 294 \\
1985 (projected) & 460 \\
\hline
\end{tabular}

*

Supporting a $1250 \mathrm{MWe}$ power plant

\subsubsection{Transportation}

No significant solid waste.

\subsubsection{Preparation}

Solid waste disposal is expensive and complex because the wastes can be hazardous and/or toxic. Additional treatment is likely to be a requirement of the pending regulations, since coal preparation solid wastes may be considered hazardous. A summary of solid wastes is presented in Table 4-17. 
Table 4-17. Coal Preparation Solid Waste Effluents

\begin{tabular}{|c|c|}
\hline TYPE OF OPERATION & TONS/DAY INPUT \\
\hline Breaking and Sizing & \\
\hline Controlled & 0.87 \\
UnControlled & 0.87 \\
Clcaning, Including Washing & \\
\hline Controlled & 39.96 \\
Uncontrolled & $1285-2767$ \\
\hline
\end{tabular}

\subsection{DISRUPTION OF LAND AREAS}

\subsubsection{Mining (Surface) and Preparation}

Land for surface mining is required for the active mining site, the spoil site, reclamat1on activities, the physical plant facility, access roads, and the water containment/treatment facility. The permanent land disruption is 2.56 acres $/ 10^{12}$ Btu. Over a 30 year lifetime at $65 \%$ capacity a 1250 MWe plant will produce $729 \times 10^{12}$ Btu resulting in permanent disruption of 905 acres. Temporary disruption, assuming a 5 year reclamation cycle, results in about 37 acres $/ 10^{12}$ Btu or 437 acres of land each year.

\subsubsection{Mining (Underground) and Preparation}

Subsistence inevitably follows extenstve underground cxtraction of coal. The elapsed time between the mining operation 3 and the surface subsistence may be from several days to fifty or more years depending on: the structural behavior of the overburden, (2) the depth of the exravation beneath the surface, (3) the percentage of coal mined, and (4) the method of mining used. The resulting damage to surface structures and land, and the destruction or contamination of water resources, constitutes a most pervasive kind of pollution. 
The following indicates the difficulty of generalizing about the prediction of subsidence:

- Normally, where extraction has exceeded 70 percent, subsidence has occurred within a few years. However, there are instances on record (e.g., Macoupin County, Illinois), where only 50 percent extraction resulted in significant subsidence within 4 years.

- In the Macoupin County case cited above, the coal seams were about 7 feet in thickness under overburdens in excess of 200 feet. In Natroma Heights, Pennsylvania, with 60 percent extraction of a 42-inch seam under 150 feet of overburden, subsidence recently occurred some 65 years after the extraction was performed.

While it appears that the degree of subsidence will be less with increased depths of mining, there is no guarantee that the problem will be eliminated. In Great Britain, the mining of a seam 2100 feet below the surface has caused surface subsidence equal to $75 \%$ of the seam thickness. Lesser amounts of surface subsidence have been noted above seams in excess of 2400 feet.

For underground mining, the permanent land requirement is 1.83 acres/ $10^{12} \mathrm{Btu}$ or about 760 acres over the plant lifetime. Incremental disruption is 17.11 acres $/ 10^{12}$ Btu yielding approximately 23 acres/year. The actual disruption at any time will depend on the rate of subsidence and on the reclamation rate.

\subsubsection{Transportation}

The estimated land use requirements for coal transportation are: slurry pipeline, 19.9 acres $/ 10^{12}$ Btu; rail, 33.9 acres $/ 10^{12}$ Btu; and truck, 1.58 acres $/ 10^{12}$ Btu.

\subsection{MANPOWER REQUIREMENTS}

Mining of coal, especially in underground mines, is labor intensive. The most recent data on mine productivity (for 1977) indicates production rates as follows:

$$
\begin{aligned}
& \text { Surface : } 26 \text { tons/man-day } \\
& \text { Underground: } 9 \text { tons/man-day } \\
& \text { Average : } 14 \text { tons/man-day }
\end{aligned}
$$

To supply the plant's average daily requirements would take a working force of 640 men for a 1250 MWe plant. 
REFERENCES

1. Shah, R.P., General Electric Co., Energy Conversion Alternatives Study (ECAS), NASA Lewis Research Center, NASA-CR 134949; 1978.

2. Grisso, J.R., Ralph M. Parsons Co., Preliminary Design Study for an Integrated Coal Gasification Combined Cycle Power Plant: EPRI: AF-880, 1978 .

3. Department of Energy/Fossil Energy Program, Fossil Energy Program Summary Document, 1979.

4. TRW, Inc., Environmental Characterizations for Energy Technologies and End Uses, ORNL, 1978 .

5. Larson, J.W., et al., MITRE Corp., High Temperature Turbine Technologies: Summary of Four Integrated Gasification and Overall plant Design Descriptiono, scptember 1978.

6. Integrated Assessments and Policy Evaluarions Group, ANL, "Preliminary Comparative Assessment of the Satellite Power System and Alternative Technologies," July 1979.

7. United Engineers and Constructors, Inc., "Commercial Electric Power Cost Studies," NUREG-0243.COO-2477-7, Vo1. 2 of 3.

8. United Engineers and Constructors, Inc., "Satellite Power Systems and Alternative Technology Characterization," UE\&C-ANL-790831. August 1979.

9. General Electric Corporation R\&D, "Energy Conversion Alternative Study (FCAS)," December 1976.

10. Peters \& Timmerhaus, McGraw-Hill, "Plant Design and Economics for Chemical Engineers," Second Edition.

11. Private communication - UE\&CI, Ed Ziegler.

12: Hudson, John Wiley \& Sons, "The Engineers' Manual," Second Edition, August 1945 .

13. TRW, Inc., "Energy Balances in the Production and End-Use of Alcohols Derived from Biomass and Coal," prepared for DOE/PE and National Alcohol Fuels Commission, 1979.

14. TRW, Inc., "Environmental Characterizations for Energy Technologies and End-uses," Volume 4, November 1978 (unpublished).

15. An ERDA Report, The Environmental Task Force, 1977, AFBL's (MOPPS, ETF).

16. MITRE Corporation, "Annual Environmental Analys is Report, Volume 4 Simulation," MTR 7626 (unpublished). 


\section{REFERENCES}

17. Brown, D. H., "Conceptual Design and Implementation Assessment of a Utility Steam Plant with Conventional Furnace and Wet Lime Stack Gas Scrubbers," Energy Conversion Alternatives Study (ECAS); Genera1 Electric Co., NASA CR-134960. December, 1976. 
SECTION 5, LIQUID METAL FAST BREEDER REACTOR 


\section{LIQUID METAL FAST BREEDER REACTOR (LMFBR)}

\subsection{INTRODUCTION}

The LMFBR plant reference design is a $3400 \mathrm{MWt}$ loop-type, sodium-cooled fast-breeder reactor plant with a nominal electrical rating of 1250 MWe. The physical LMFBR plant area will be about 70 acres, including the reactor building, switchyard, parking lot, access roads, and wet cooling towers. As a minimum, a buffering area of 400 acres is needed. This requires a total area of 500 acres. The plant design was developed by United Engineers for the Department of Energy. (DOE) on the Energy Economic Data Base (EEDB) program as described in "Satellite Power System and Alternate Technology Characterization." Additional input was derived from the proposed Final Environmental Statement "Liquid Metal Fast Breeder Reactor Program," WASH-1535.

The LMFBR is a nuclear fission reactor which, in addition to producing energy, converts $\mathrm{U}^{238}$ in its core to plutonium at a rate which produces more fissile material ( $\mathrm{Pu}^{239}$ and $\mathrm{Pu}^{241}$ ) than it consumes. Liquid sodium is used to remove heat from the reaction and to power the steam cycle to generate electrical power. Excess plutonium produced by the LMFBR will provide fuel for other breeders as well as conventional LWR's.

The description in this report is structured with the purpose of comparing one technology with another, both projected to the year 2000 . First, it was necessary to make the technologies comparable in terms of electrical energy generation. 1250 MWe was chosen as being representative of large bulk power generation facilities in the year 2000 .

The 1000 MNe LMFBR (About $2500 \mathrm{MWt}$ ) was scaled up to 1250 MWe because the cost estimate is also based on this plant and major equipment. Although scaling does provide a valid general representation of the 1250 MWe plant, a more representative or meaningful characterization would have been obtained if the LMFBR Program had proceeded further beyond the 19.74 conceptual design phase.

During the past 10 years, the basic designs of the nuclear facilities have changed dramatically. Size of the units has increased to about 1250 MWe (3800 MWt) and extensive safety systems have been incorporated. Between now and the year 2000, size is assumed not to increase beyond present standards because of NRC safety concerns. However, safety will continue to be a major 
driving force in the design modifications of nuclear facilities. Investigations of the Three Mile Island accident will produce design changes for safety reasons in the near term. In the far term, through the year 2000 , the continued striving for a "perfectly safe" form of nuclear energy will result in numerous design changes required by the regulatory agencies to enhance safety.

Although the LMFBR does not presently exist as a commercial bulk power generation source, it is assumed to be available in the year 2000 . In the past few years, INFBR technology has advanced beyond basic feasibility to the extent that prototype pumps, valves, heat exchangers, and other components have been bullt, tested, and placed in service in large demonstration plants throughout the world. Although a major engineering effort is necessary to demonstrate and deploy an energy concept, no technological breakthroughs are required for IMFBR. Remaining uncertainties mainly concern putting the existing technology into commercial practice by designing, constructing, operating, and maintaining commercial-scale units that can compete with other power plant concepts for the 21 st century and beyond.

Pollution control equipment will continue to be required for power generation facilities. For a nuclear plant, better radiological control equipment will be developed and installed to minimize or eliminate entirely hazardous radionuclide emissions. In addition, pollutant abatement regulations are assumed to require no process stream discharges containing any pollutants. The only assumed exception to this basic assumption is the cooling tower blowdown. However, degradeable biocides and corrosion inhibitors are assumed to be used in the cooling towers. Ice prevention is accomplished through temperature control.

The reference liquid metal fast breeder reactor (IMFBR) described in this section is a single unit plant. It represents an envelope of the currently available design thinking for commercial plants of the five principle U.S. manufacturers of nuclear IWR plants, Atomics International (AI), Babcock \& Wilcox (B\&W), General Electric (GE), Westinghouse, and Combustion Engineering (CE). The basic nuclear plant is coupled to a balance-of-plant concept designed by United Engineers and Constructors (UEC) as described in their reports "Commercial Electric Power Cost Studies", and "Satellite Power System and Alternative Technology Characterization". The primary 
features of the UEC design are the Nuclear Stream Supply System (NSSS), four flow tandem compound turbine generator with supporting power conversion cycle equipment and systems, and the station cooling system using three mechanical draft wet cooling towers.

The overall design of the unit was based on the licensing, design, construction and operation criteria, standards, codes, and.guidelines in effect circa January 1, 1978. The characterization represents the current state of technology in the late 1970 's but projected to the year 2000 . It must be realized that between the time the reference plant was designed and the year 2000 , numerous.changes will be made in the design requirements of the LMFBR levied by the various regulatory agencies. These design requirement changes will impact the basic design of the unit and its cost. Many of the changes will be derived from the lessons learned from LWR licensing experience. However, many more design changes will probabiy be required through the year 2000 as LMFBR operating experience, which cannot be quantified nor anticipated at this time, is gained. Caution must thus be exercised in the use of this design projected to the year 2000. 


\subsection{GENERAL PLANT CONFIGURATION}

A plot plan for the LMFBR facility is shown in Figure 5-1. It consists of a 184-foot diameter cylindrical, domed, reinforced concrete containment, a reactor service building, two auxiliary buildings, two reactor decay cooling buildings, and the control building. These buildings are arranged in a cluster with the reactor containment building in the center. All are supported on a common base mat founded on rock. Two of the four steam generator buildings are located on elther slde and adjacent to the nuclear island buildings. The turbine building is located adjacent to the nuclear island buildings' on the end opposite to the reactor service building.

Heat generated in the reactor is transferred by forced ifrculablun of liquid sodium primary coolant to the intermediate heat exchangers. Then, the heat continues through a nonradioactive secondary sodium coolant system to steam generators in which superheated steam is produced. This steam drives a set of tandem-compound turbines. Waste heat released by condensation of exhaust steam from the turbine is rejected to the atmosphere through three mechanical draft, wet cooling towers.

The balance of the reactor plant systems includes reactivity control system, radwaste system, service waste systems, combustible gas controls, fuel handling, fuel storage, reactor makeup water system, the primary component cooling water system, and the air cleanup system. The balance of the conventional portion of the plant includes the usual transformer, switchgear and switchyard components, and the connection to the distriburion 11nes. The main condenser heat rejection system includes makeup water intake and discharge structures, a circulating water pumphouse, makeup water pretreatment facilities, and three mechanical draft, wet cooling towers. 
PLANT NOMENCLATURE

1. Reactor Containment

2. Reactor Service Building

3. Turbine Building

4. Healer Bay

5. Control Building

6. Diesel Bulding

7. Administration Building

8. Auxiliary Building No.

9 Auxiliary Building No. 2

10 Auxiliary Heat Iransiter System Bay No. 1

11 Auxifiary Heat Iransier System Bay No. 2

12 Steam Generator Building No. 1

13. Steam Generator Building No. 2

14.

15. Steam Generator Building No. 4

16. Piant Maintenance

17. Auxiliary Boiler

18. Water Treatment

19. Loading and Unloading Facility

20. Non Essential Switchgear Building

21. Transformer Area

22. Security Building

23. Make-Up Water Intake Structure

24. Make-Up Water Pretreatment Building

25. Hotdiny Pond Plant Effluent

26. Firo Water Pump House

27. Fire Water Siorage Tasks

28. Uitimale Heat Sink

29. Cooling Towers

30. Cooling Towers Switchyear Building

31. Switchyard

32. Fuel Oil Starage Tank

33. Parking Area

34. Guardhouse

36. Security Fence

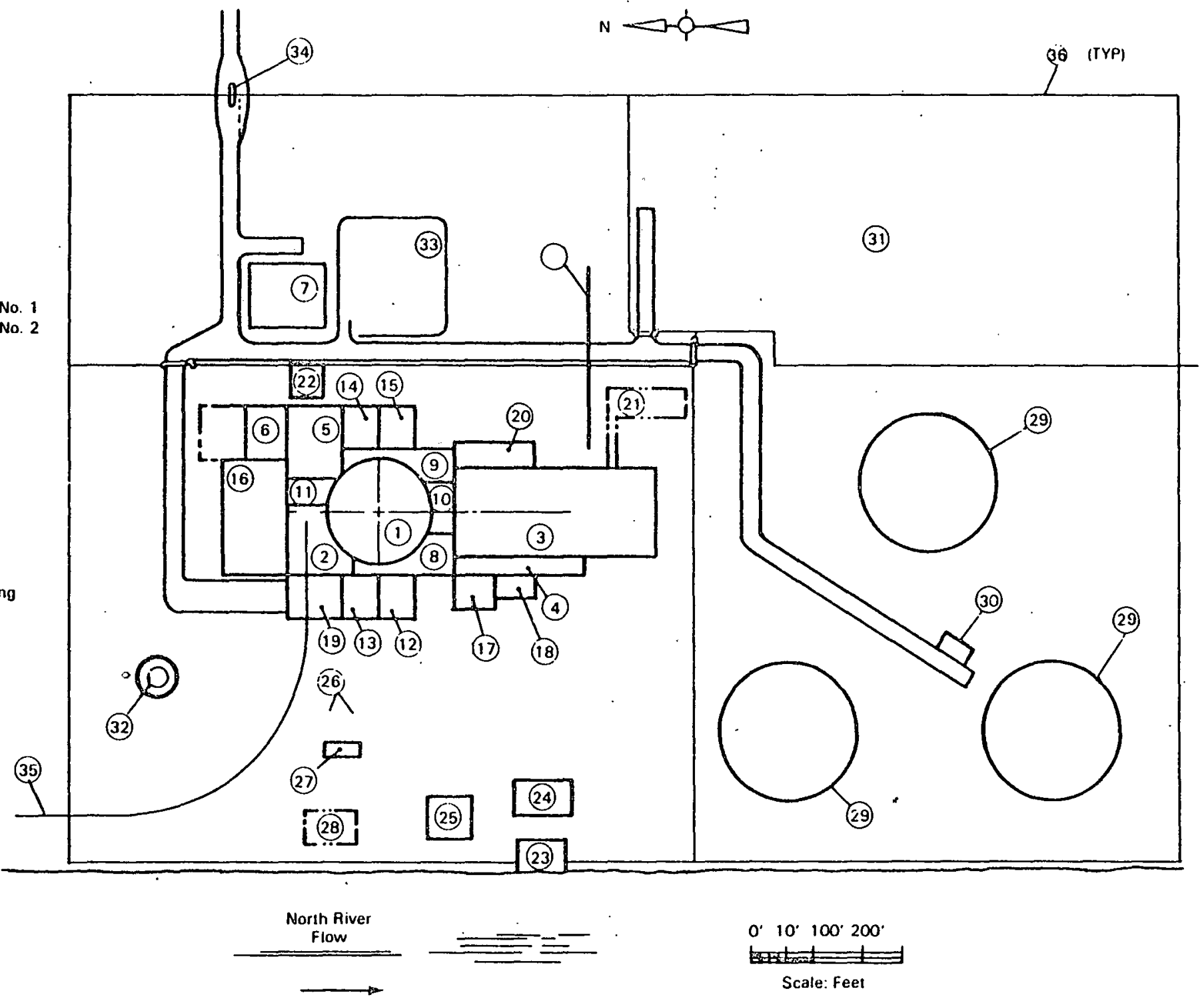

Figure 5-1. The Plot Plan for the LMFBR Facility 


\subsection{THERMODYNAMIC CYCLE CHARACTERISTICS}

The LMFBR primary system consists of a liquid, sodium-filled nuclear reactor having a reactor core containing low enriched uranium and plutonium oxides in approximately 670 fuel and 1,100 blanket assemblies. The core is refueled by replacing approximately one-third of the assemblies after achieving a 67,000 MWD/T average burnup. Both the new and spent reactor fuels are radiologically hot and must be stored in heavily shielded areas.

The reactor produces approximately $3417 \mathrm{MWt}$ at nominal full power. The LMFBR Heat Transport system removes the heat generaced by the reactor core and converts it to the rotational mechanical energy required by the generator to produce electric power. The overall system consists of a radioactive primary coolant system, a nonradioactive secondary coolant system, a steam generation system, and a steam plant system, the latter including the turbine that delivers the required mechanical energy to the electrical generator. A simplified systems diagram is given in Figure 5-2.

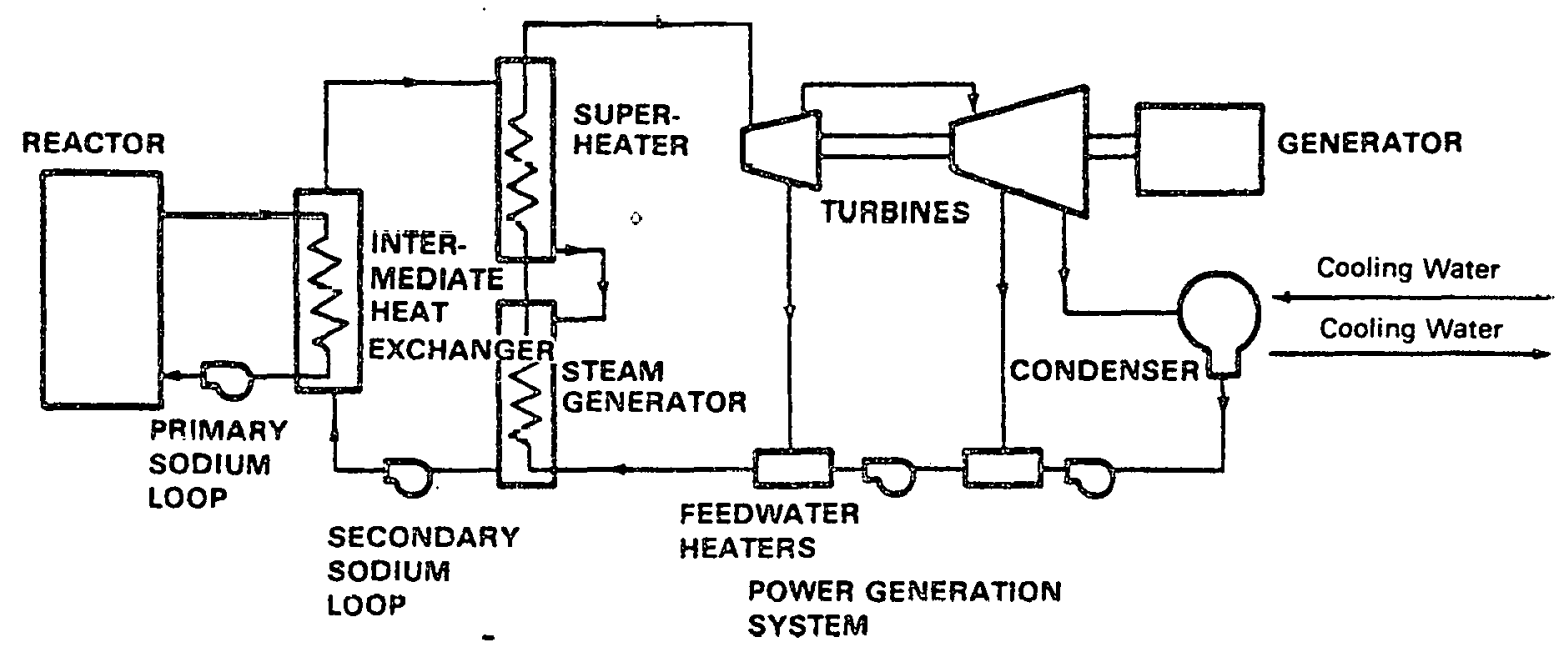

Figure 5-2. Simplified Diagram of Heat Transfer System 
The primary coolant system consists of several redundant circulating loops that conduct sodium from the core exit plenum of the reactor vessel. and circulate it through internediate heat exchangers. Here, the heat is transferred to the sodium of the secondary coolant system. The primary sodium then returns to the reactor vessel. In the secondary system, secondary sodium is heated in the intermediate heat exchangers and is circulated to the steam generation system. There are four parallel primary loops and four secondary loops, one serving each primary loop.

Two basic arrangements, the pool- and loop-type configurations, for the primary coolant system have been proposed. These are depicted schematically in Figure 5-3. In the pool-type configuration, the reactor, intermediate heat exchangers, primary pumps, and interconnecting piping are all immersed in a large primary tank filled with sodium. In operation, sodium is drawn from the bulk content of the tank by the primary pumps and is forced through the reactor. Then, the sodium flows by gravity through the intermediate heat exchangers and discharges back to the bulk sodium in the primary tank. The driving force for intermediate heat exchanger flow is the difference between the levels of sodium over the reactor and in the remainder of the primary tanks. With this configuration, the primary tank with its cover and the tubes and tube sheets of the intermediate heat exchangers constitute the primary coolant system boundary.

The primary coolant arrangement is the loop-type configuration where the primary pumps and the intermediate heat exchangers are located external to the reactor vessel. Either hot or cold leg pumps could be used in the primary system. The primary loop piping is elevated and guard vessels are provided around the pump, intermediate heat exchanger, and reactor vessel so that leaks in the primary piping or these components cannot cause the sodium level in the reactor to drop below the minimum safe level. Thus, the loop nozzles would be covered, and continuous heat removal by sodium circulation through the loops could be permitted. The LMFBR characterized in this section is a loop-type plant. 


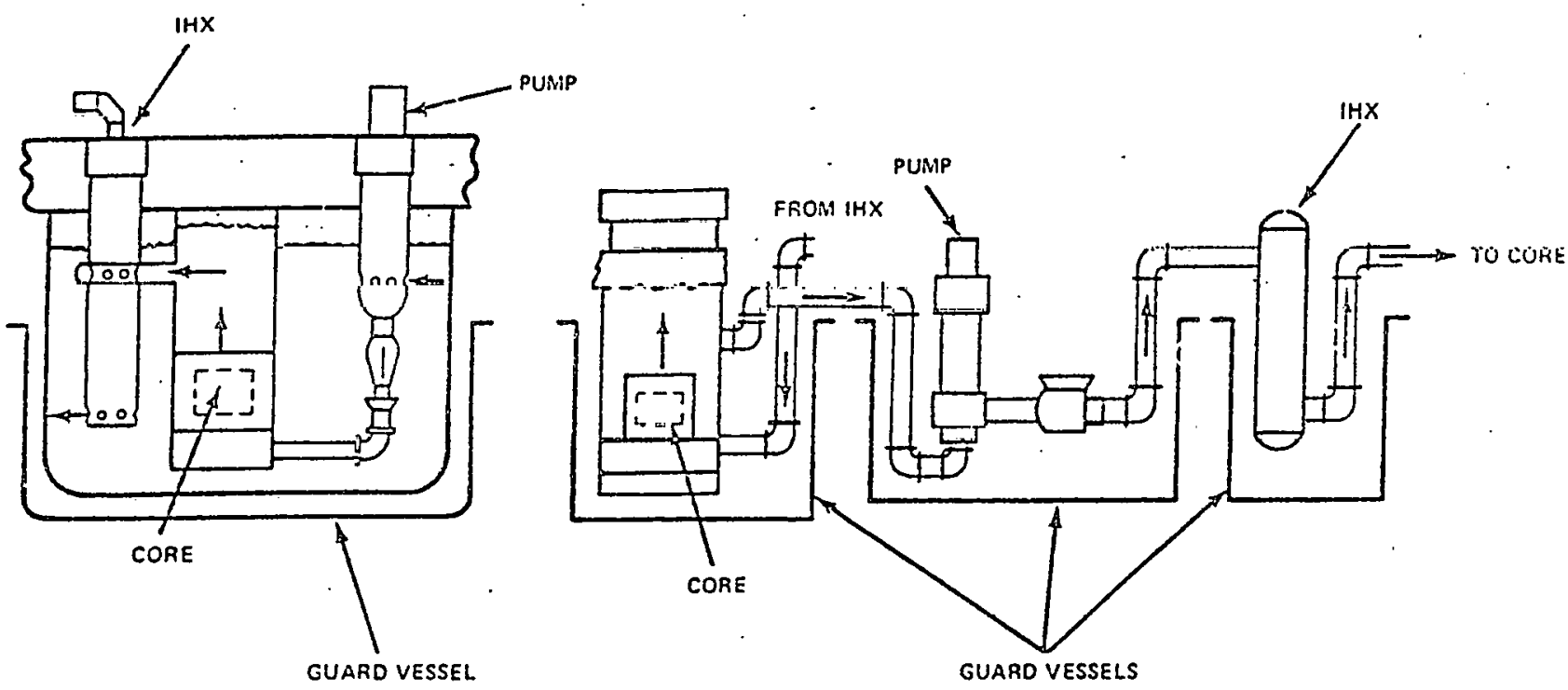

Figure 5-3. Pool and Loop-type Primary Coolant System Configurations

The primary sodium system is destgned to operate at a lower pressure than the secondary system. Thus, should a leak develop in an intermediate heat exchanger between these two systems, any leakage should progress from the nonradioactive secondary system into the radioactive primary system. Finally, even though such leakage would not result in a radiological problem in the secondary system, the intermediate heat exchangers are designed to facilitate removal or replacement of faulty tubes.

The overall steam cycle is expected to be similar to that of moderit fossil-fired steam-electric power plants. The turbine designed assumed in this study is a set of tandem compound fossil turbines. 


\subsection{REACTOR HEAT-GENERATION SYSTEM}

The reactor heat-generation system consists of the reactor core, control rod drives, and reactor vessel. The core is an array of fuel assemblies, which are vertically disposed and surrounded by one or two rows of radial blanket assemblies and one row of reflector assemblies. Control assemblies are interspersed with the fuel assemblies in a regular pattern.

The fuel material is mixed plutonium-uranium oxide. Fuel elements are helium filled to enhance heat transfer across the gap between fuel and cladding. Blanket material, both axial and radial, is depleted uranium oxide. The control absorber material is assumed to be boron carbide $\left(B_{4} C\right)$, although other materials are also under consideration.

The core component handiing system has the function of handing fuel and other core assemblies from their receipt at the reactor plant through acceptance testing, storage, conditioning, and insertion into the reactor core; and during removal of the core assemblies from the reactor, the handling system provides for the storage for decay of post-irradiation heat generation (commonly called "decay heat storage"), and the inspection, cleaning, and packaging of this material for shipment to reprocessing facilities.

A number of different basic design approaches have been proposed for commercial-size LMFBR power plants for the removal of spent core assemblies from the reactor and for their decay heat storage prior to shipment from the plant site. The principal differences between the approaches are in the 10cation of the decay storage facilities and in the method of transferring assemblies between the core and storage positions. Reduction of the reactor down-time necessary for refueling operations to the minimum length of time consistent with plant safety is aimed at improving plant availability and consequently plant economics, the prime goal of all approaches. 


\subsection{AUXILIARY SYSTEMS}

The plant contains a number of auxiliary systems to perform specific support functions:

- Liquid metal receiving and processing

- Inert gas receiving and processing

- Auxiliary heating and cooling

- Radioactive waste processing

$\rightarrow \quad$ Servicing and utility functions

Of these systems, radioactive waste processing systems are perhaps the . most important in terms of environmental considerations and are described briefly in Section 4.2 .

The LMFBR primary system is a completely closed system in which the sodium and cover gas* are continually pruified to maintain radioactivity at low levels. Four radioactive waste processing systems are provided:

(1) Gaseous waste system, subdivided into reactor cover gas and cell atmosphere purification systems

(2) Iiquid waste system

(3) oolid watc gystem

(4) sodium waste system

Table 5-I presents key plant parameters.

* Argon gas is used to keep the sodium atmosphere inert. 
'Table 5-1. Key Plant Parameters for LMFBR Primary System

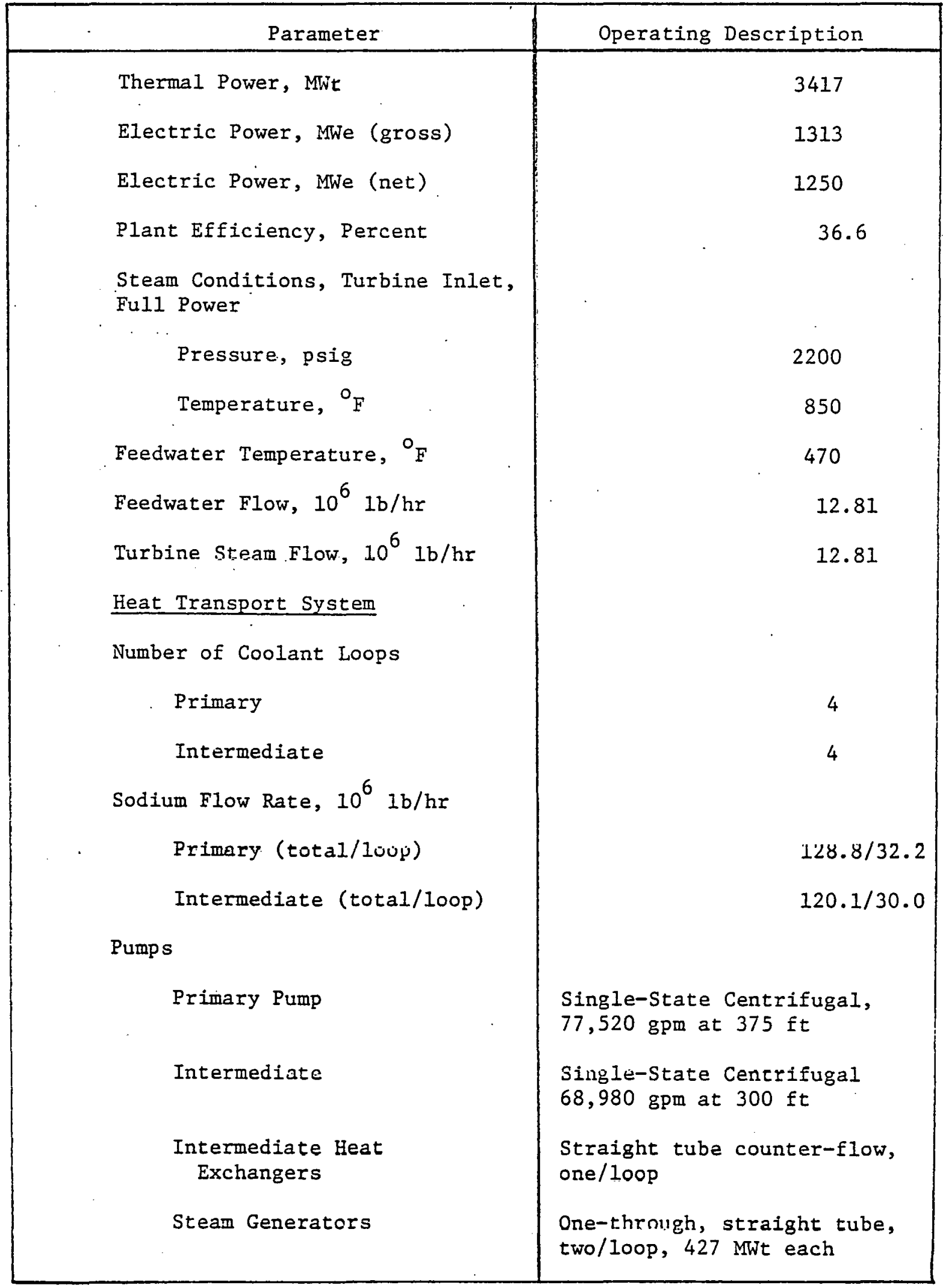




\subsection{INSTRUMENTATION AND CONTROL}

The plant instrumentation and control system consists of three basic parts: the protection system, data system, and control system. The protection system provides for the measurement of neutron flux density from startup to full power, coolant and component temperatures, system pressures, sodium flows and levels, gamma radiation, radioactive gases and particulates, and other parameters of interest or necessity.

\subsection{REACTOR CONTAINMENT}

An important safety feature of the LMFBR commercial plant concept is the multiple containment of fission products generated in the fuel elements during reactor operation. The barriers to fission produce release are the fuel element cladding, the boundary of the primary coolant system, and the outer reactor containment.

The outer containment consists of a leak-tight cylindrical steel or steel-lined concrete building having a flat bottom and hemispherical or ellipsoidal dome. The containment building houses the reactor and entire primary coolant system, spent fuel handing and storage facilities, and sodium service systems related to the primary system.

\subsection{TURBINE GENERATOR CONFIGURATION}

The turbine configuration consists of two one-half capacity tandem compound, four flow machines with 33:1/2-inch last stage plants designed and operated at $3600 \mathrm{rpm}$. Inlet steam conditions at the HP throttle valves are 2200 psia and $850^{\circ} \mathrm{F}$. This reactor plant designed provides the superheat so the inlet steam is not at saturation and resembles steam conditions in a tossil-tịed power plant.

Turbine shaft power and generator output is about equally distributed to the two shafts. Each of the two generators is rated at 722 MVA with 0.90 PF, 26,000 V, 3 phase and $60 \mathrm{~Hz}$ output. Fixed and generation losses respectively account for $1,509 \mathrm{~kW}$ and $9,934 \mathrm{~kW}$ per generator, thus resulting in a gross generator output capacity of $1,313,000 \mathrm{~kW}$, before accounting for auxiliary electrical loads. 


\subsection{CONDENSER-HEAT REJECTION SYSTEM}

Two multi-pressure, single-pass surface condensers with divided fabricated steel water boxes and shell are provided. The condensers are designed to condense the low-pressure turbine outlet steam and feedwater pump auxiliary turbine drive exhaust steam by dissipating the heat to three mechanical draft, wet cooling towers. Each condenser contains about 325,000 $\mathrm{ft}^{2}$ of condensing surface made up of 1-1/8 inch diameter, 20 BWG 90-10 CuNi tubes.

The three main mechanical draft water cooling towers are each sized for one-third of the requirements. Each tower is designed to cool 195,000 gpm of water from $118^{\circ}$ to $92^{\circ} \mathrm{F}$ when operating at a wet bulb temperature of $74^{\circ} \mathrm{F}$. Each tower employs a reinforced concrete-filled structure combined with components for water distribution, fill spash service, support system, drift eliminators, louvers, and fan deck. The fan deck provides a stable base for the 12 fan cylinders and mechanical equipment. Each fan is $33 \mathrm{ft}$ in diameter and operates in an $18 \mathrm{ft}$ high glass reinforced-polyester velocity recovery fan stack. The hot water distribution system includes a circular flume distribution basin and metering orifice which uniformly distributes the hot water over the fill.

\subsection{FEEDWATER HEATERS}

Feedwater flow from the condenser enters a six-series reverse-cascade feedwater heaters designed to achieve a final feedwater temperature of $440^{\circ} \mathrm{F}$ at $12.81 \times 10^{6} \mathrm{lb} / \mathrm{hr}$. The first five stage heaters are low pressure and the final stage only designed for full steam generator pressure. Steam for the feedwater heaters is provided from the moisture separator, various extraction points throughout the steam cycle, and other residual stream flows. A total of $5901.4 \times 10^{6} \mathrm{Btu} / \mathrm{hr}$ is added to the feedwater before entering the boiler as shown in Figure 5-4. The condensate and feed pumps contribute small amounts of energy. 


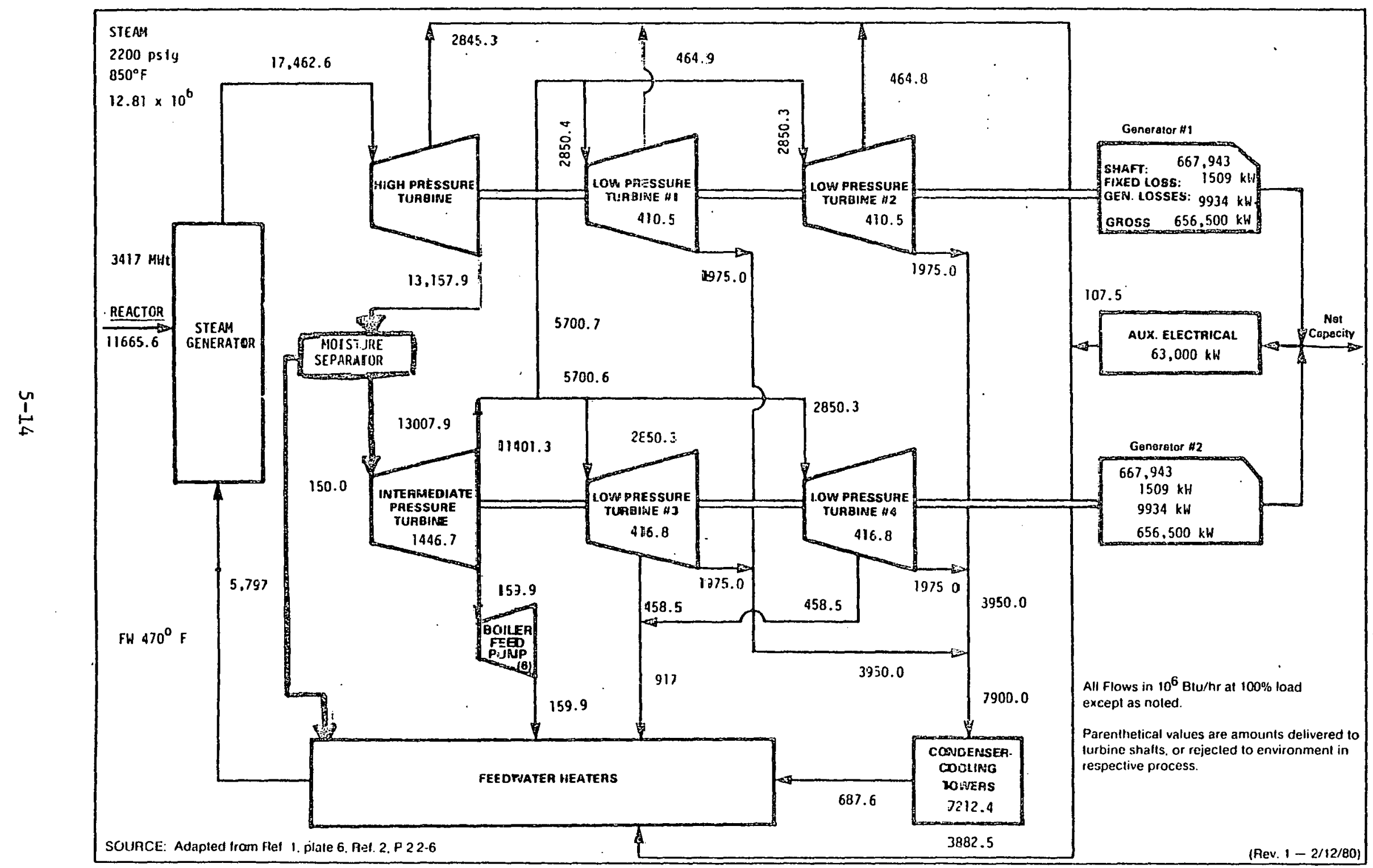

Figure 5-4. Simplified Cycle Schenatic - 1250 MWe - Reference LMFBR Facility 


\subsection{GENERATOR LOSSES AND ANXILIARY ELECTRIC ENERGY USE}

The total power delivered to the turbine shaft is about 1,334,214 kWh. Various generator inefficiencies result in the loss of $21,214 \mathrm{~kW}$ or 1.59 percent of the shaft power as fixed and generation 1osses. Approximately 63,000 $\mathrm{kWh}$ is required to support the plant operation, resulting in a net output of $1,250,000 \mathrm{kWh}$.

\subsection{FUEL USE AND LOGISTICS}

A sumary of typical annual fuel requirements for a 1250 MWe LMFBR plant is presented in Table 5-2. The nuclear fuel is uranium--plutonium oxide; quantities stated are for the heavy metal (uranium or plutonium) content only. The axial and radial blankets are listed separately. The following estimates are the nominal plant operations.

The refueling of the 1250 MWe LMFBR power plant operating at nominal capacity requires about 23 Metric Tonnes Heavy Metal (MTHM) as the nuclear fuel. The blanket material contains about 64 MTH which breeds fissile Pu. The $\mathrm{Pu}$ is recovered via reprocessing, which results in the generation of high-level wastes. These waste products are made up of fission products and fuel element hull material, stainless steel. Austenitic stainless steel is used as part of the replaceable fuel elements; the steel is not chemically consumed but is rendered radioactive in the reactors. The steel cannot be decontaminated and thus is considered consumed, rather than recoverable, and disposed of as waste. 
Table 5-2. LMFBR Fuel Design Parameters

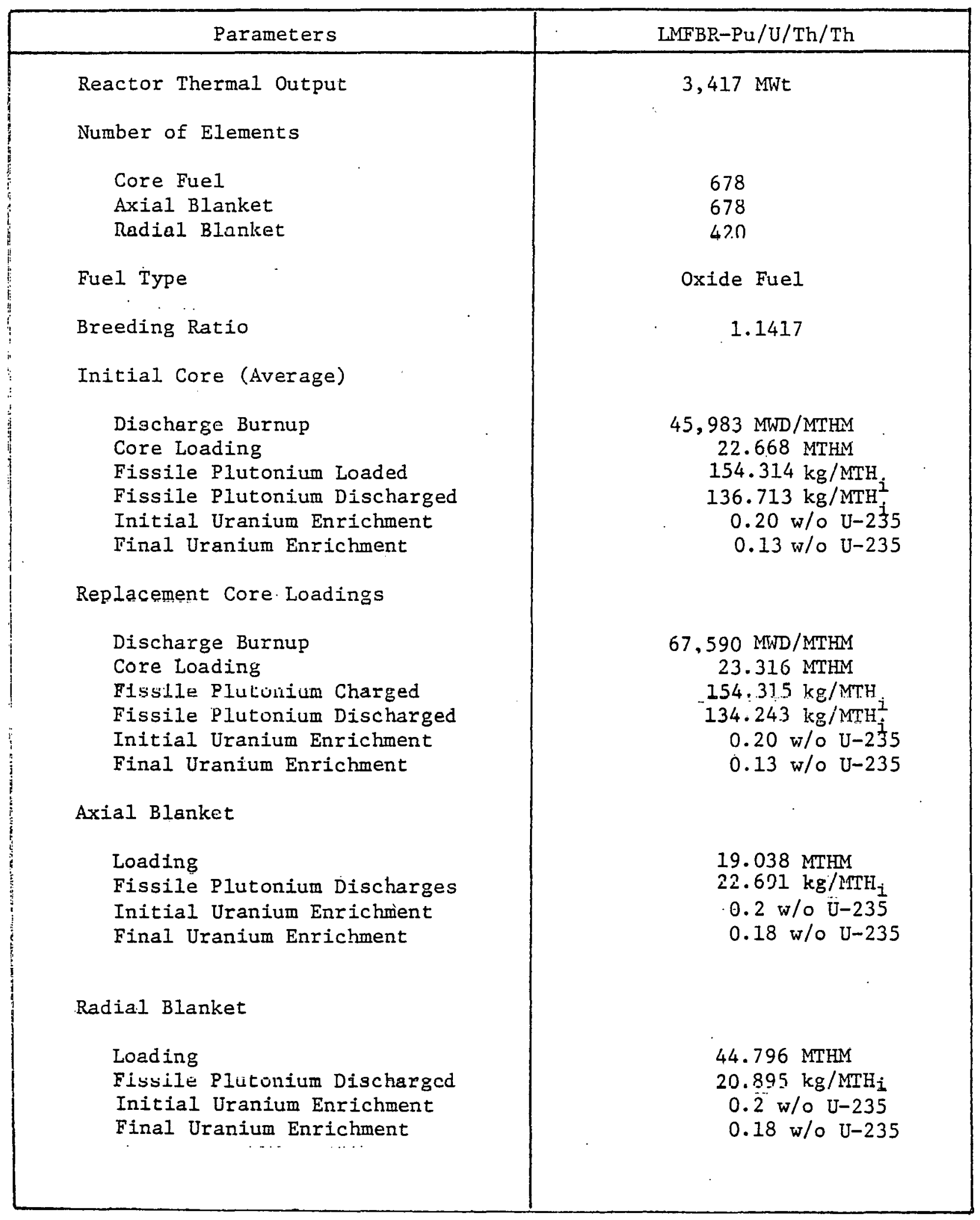


The LMFBR power plants and fuel cycle facilities consume chemicals and certain replaceable components in addition to water, fuels, and the materials of construction. These additional requirements are:

(1) Chemicals for treating natural water for cooling water systems. The use depends on the water quality; the chemicals most commonly used are chlorine and sulfuric acid.

(2) Ion-exchange resins for removal of radioactivity from aqueous waste streams. The quantity depends on source terms and methods ficr treatment.

(3) Ion-exchange resins for purification of water for internal plant uses. The quantity used depends on the water quality and the type of resin.

(4) Chemicals for regeneration of ion-exchange resins. These chemicals are usually sulfuric acid and sodium hydroxide; the quantity used depends on water quality.

(5) Containers for packaging radioactive effluent from the radioactive waste systems. The number of containers depends on the amount of radioactive materials to be disposed of and the particular process used in the various systems. These containers are steel, concrete, or other common structural materials.

(6) Sodium coolant for the primary and secondary coolant loops of the power plant.

(7) Miscellaneous chemicals, principally nitric acid and solvents for the reprocessing plant. These are not critical materials from a resource standpoint, and amounts not recycled are handled as wastes.

All of the above chemicals are of common types and are used in moderate amounts relative to $U$. S. Industrial practice. Sodium is a low-cost industrial material obtained from virtually inexhaustible salt resources. Sodium is not chemically transformed in its use as a coolant and is retained except for small removals during the plant lifetime. The sodium in the primary loop is rendered radioactive, which may make it unacceptable for uses other than as primary coolant in LMFBR power plants. 


\subsection{ENVIRONMENTAL CHARACTERISTICS}

Numerous reactor plant systems, even under normal conditions, become contaminated with radioactive elements. These elements can come from the fuel itself, impurities in the fuel cladding, activated wear products, or other sources. Because several systems are contaminated, normal maintenance, operations, and leaks will lead to release of some of these elements.

The building ventilation systems and processed liquid effluents are the transport mechanisms for release of these radioactive elements. Areas which have the potential for contamination are ventilated through high-efficiency particulate filters which remove $>99.9$ percent of the particles in the air greater than 0.3 microns. Potentially contaminated liquid effluents are monitored or processed to remove radioactive elements primarily by filtration and ion exchange. In each case, not all of the radioactive elements can be prevented from entering the biosphere. Consequently, radioactive elements are emitted to the biosphere by the LWR.

\section{I AIR EMTSSIONS}

Radioactive noble gas emiscions are the 1mportant gaseous emissions from an LMFBR plant. Table 5-3 shows the estimated airborne iddidundide releaco froin the reference 1250 MNe LMFBR farility.

Table 5-3. Postulated Radionuclide Releases--1250 MWe LMFBR Puwer Plant at $70 \%$ Capacity Factor

\begin{tabular}{|l|c|}
\hline Nuclide & $\begin{array}{c}\text { Atmospheric Release } \\
\text { Ci/year }\end{array}$ \\
\hline $\mathrm{H}-3$ & 6.5 .63 \\
$\mathrm{Ar}-39$ & 87.50 \\
$\mathrm{Kr}-85 \mathrm{~m}$ & .33 \\
$\mathrm{Kr}-85$ & .44 \\
$\mathrm{Kr}-87$ & .44 \\
$\mathrm{Kr}-88$ & .54 \\
$\mathrm{Xe}-133$ & .03 \\
& \\
\hline
\end{tabular}


Both the dose from airborne releases and radiation from the LMFBR power plant are well within the guidelines proposed in Appendix I of 10 CFR 50, currently a guide for LWR's.

LMFBR facility chemical discharges are assumed to be the same as the LWR. These discharges are from the cooling towers and are comprised of chlorine, chromates, and zinc. As with the LWR facility, chemical discharges present no hazard to the environment.

\subsection{LIQUID EFFLUENTS.}

The aqueous chemical wastes from a nuclear power plant generally enter the environment via the blowdown stream from a closed-cycle cooling system or the circulating cooling water stream from an open-cycle system. In actual practice, the chemical composition of these waste streams is as varied as the number of existing discharges. Nevertheless, the nature of some of these wastes can be categorized according to their origin and somewhat by their chemical makeup. The major sources of the waste streams from a nuclear power plant are those originating from the condenser cooling system and the process water system. All other waste streams are minor compared to them. Negligible radioactive effluents will be emitted from an LMFBR plant. A summary of effluents is provided in Table 5-4. 
Table 5-4. IMFBR Wastewater Effluents at Nominal (1250 MWe) Operation

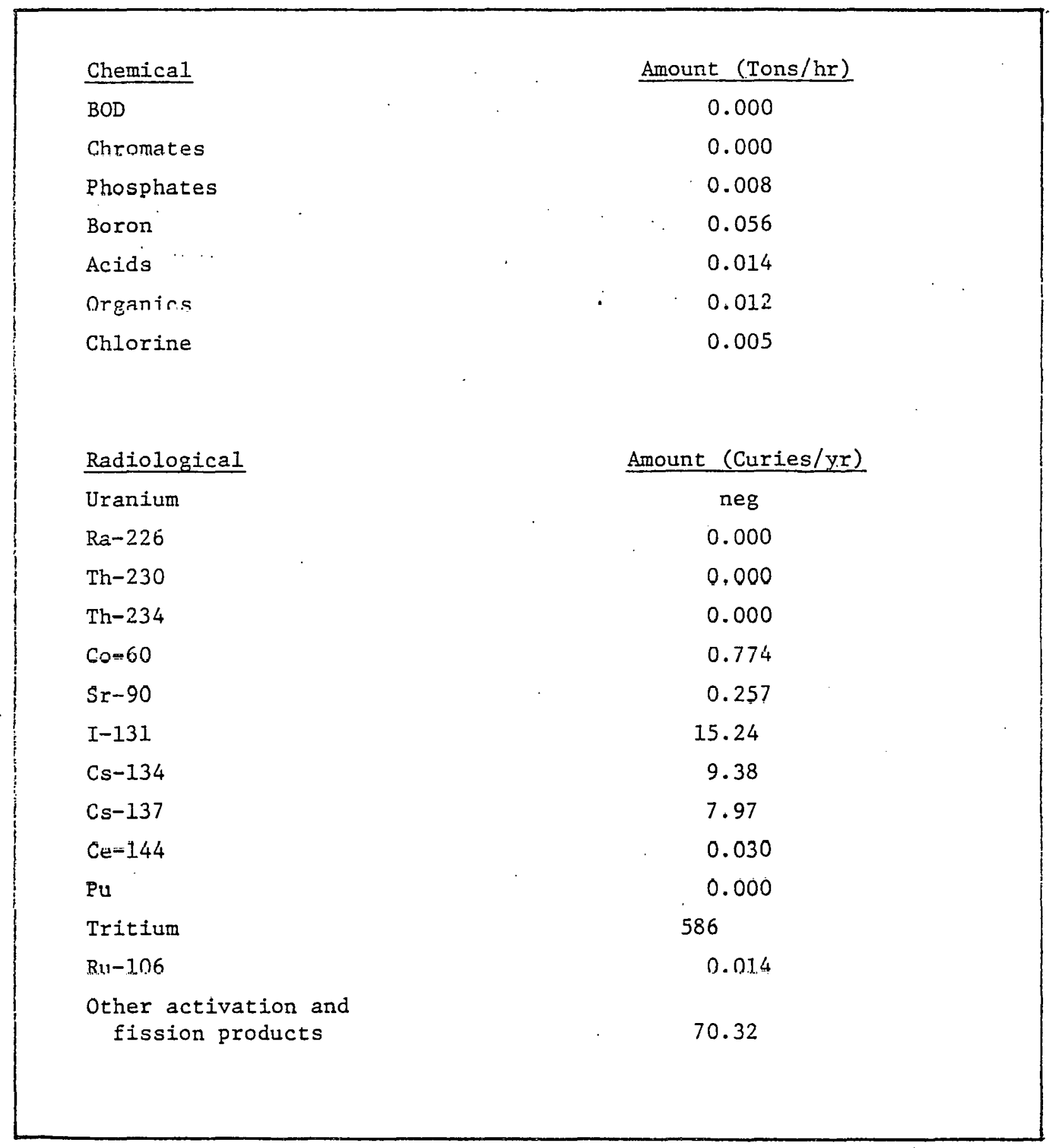




\subsection{SOLID WASTES}

Solid wastes generated at the reactor will consist typically of filters from the heating and ventilation system, deactivated primary coolant sodium cold traps, analytical laboratory and liquid waste treatment residues, contaminated tools and parts, and waste such as plastic bags, footcovers, paper towels, and protective clothing. These wastes will be compacted and packaged in 55-gallon sealed drums. Then, the wastes are shipped to a low-level waste burial ground. About $9.4 \mathrm{ft}^{3}$ of tritium waste per year in the form of $\mathrm{Ca}\left(\mathrm{O}^{3} \mathrm{H}\right)_{2}$, will be included in these solid wastes.

About 3,117 curies of beta-gamma waste and about 30,000 curies of tritium waste will be generated each year.

\subsection{REJECT WASTE HEAT}

The 1250 MWe LMFBR would reject about $7.1 \times 10^{9} \mathrm{Btu} / \mathrm{hr}$ through the cooling towers. In addition, there will be miscellaneous thermal losses to air (called general plant losses) amounting to less than $1 \%$, a value typical of present-day nuclear facilities.

The primary environmental controls for radioactivity are:

- Control of radioactive noble gases

- Reactor cover gas purification

- Cell atmosphere purification system

- Liquid waste system

- Solid waste system

- Sodium waste system

- Gaseous waste system

The gaseous waste system processes all gases that can become contaminated with gaseous or volatile radioactive species. These species include:

(1) Fission products escaping from failed fuel, notably the noble gases, halides, and alkali metals

(2) Ar-39 generated from potassium impurities in the coolant

(3) Activated sudium aerosol and vapor 
Two separate systems will be utilized to control radioactive noble gases. These two systems are: (1) the reactor cover gas purification system, and (2) the cell atmosphere purification system.

- Liquid Waste System

The liquid waste system processes all potentially contaminated liquids before the liquids leave the plant. The sources of the liquid waste streams are the fuel handling area, the sodium waste system, laboratory areas, laundry, maintenance, and other support systems. The quantity of liquid waste entering the system is expected to be between 20,000 and 40,000 gal/year, which is primarily low-level radiation or contamination. (The liquid waste system will not handle tritium-containing effluents from the steam system; this waste stream has been discussed previously.)

- Solid Waste System

Solid waste will be generated by waste systems, fuel handing operations, and laboratory and maintenance operations. The waste will be in such forms as spent resins, sludges, filters, clothing, and tools.

- Sodium Waste System

The purpose of the sodium waste system is to convert small amounts of metallic sodium waste, both radioactive and nonradioactive, into a less reactive form.* The principal sources of sodium waste at the reactor are spent cold traps. Other possible sourees are sodiumcontaminated hardware (equipment and spent fuel assemblies).

\subsection{LAND AND WATER USE}

Approximately 70 acres of land will be required for facilities associated with the IMFBR power plant; namely, the reactor buildings, turbine building, switchyard, parking lot, access roads, and cooling towers. As a minimum, an exclusion area of at least 400 acres is needed, and presently most LWR stations are on even larger sites.

Decisione rolating to the siting of LMFBR power plants are expected to be guided by practices, guidelines, and criteria. These will have been developed and established through experience gained in the construction and operation of nearly one full generation of large, IWR nuclear power plants and siting of LMFBR demonstration power plants. Major changes are not anticipated in the guidelines currently in use.

* Sodium waste may not be processed onsite for LMFBR power plants. 
A number of economic, safety, and engineering factors will determine the choice of a site for a specific LMFBR power plant. The acceptability of environmental impacts caused by the construction and operation of the plant is also under consideration. LMFBR siting must be responsive to public concern for the quality of the environment.

Consumptive water use results primarily from cooling tower evaporative losses, cooling tower blowdown, and general plant use. By far, the largest consumers of water are the mechanical draft, cooling towers which use approximately 844,000 gal/hr. Table 5-5 identifies this and other plant water uses.

Table 5-5. Water Use - 1250 MWe LMFBR

\begin{tabular}{|c|c|c|}
\hline \multirow{2}{*}{ USE } & \multicolumn{2}{|c|}{ Million Gallons/Day } \\
\cline { 2 - 3 } & $100 \%$ Power & $70 \%$ Power \\
\hline Cooling Tower Evaporation & 21.9 & 15.33 \\
Cooling Tower Blowdown & 6.35 & 4.45 \\
General Plant Use & $\frac{1}{29.25}$ & 20.78 \\
TOTAL & & $<$ \\
\hline
\end{tabular}




\subsection{CONSTRUCTION AND OPERATION CHARACTERISTICS}

Studies undertaken by United Engineers and Constructors for the AEC indicate that construction labor requirements for LWR power stations range from about 6 man-hours $/ \mathrm{kW}$ for a multiple-unit station with 2,000,000 kW units to 8 man-hours $/ \mathrm{kW}$ for a single $1,300,000 \mathrm{~kW}$ unit station. It is assumed that the construction labor requirements for LMFBR Power Stations will be approximately the same as those for LWR's.

The cunstruction of an LMH'BR facility is subject to delays similar to an LWR which include:

- Litigation

- Financial problems

- Large changes in the need for power

- Licensing requirements for facility changes and back fits

- Licensing holds

There are other reasons for extended construction periods that may be experienced. Without any of these delays, a 1250 MWe LMFBR facility could be constructed in 72 months. If the delays expected to occur are inclurer in this estimate and licensing is also included (two step process with a cnnstruction permit and operating license included) the LMFBR facility could be completed in 12 years. (Recent experience with LWR construction and the novel design of the LMFBR indicates that a 12 year completion is almost a certainty.) Muring the onste construction period, an estimated 11.5 million man-hours of direct craft labor would be required primarily from 16 different labor types as described in Table 5-6. Indirect labor hours are also included.

Normal operation of the facility would require a plant staff averaging 225 persons and over 450,000 man-hours per year as shown in Table 5-7. The number of personnel on site would vary considerably from to time depending on the operation of the unit. When the unit is down for refueling/repair, the total number of personnel on site would peak at a number considerably higher than 225. 
Table 5-6. Direct Craft Labor Surmary--1250 LMFBR Plant Cost Basis - January 1978

\begin{tabular}{|c|c|c|}
\hline Craft Description & $\begin{array}{c}\text { Site } \\
\text { Labor Hours }\end{array}$ & $\begin{array}{c}\% \\
\text { Hours }\end{array}$ \\
\hline Asbestos Worker & 133,850 & 1.1 \\
\hline Boiler Maker & 745,282 & 5.9 \\
\hline Bricklayer & 142,362 & 1.1 \\
\hline Carpenter & $1,516,060$ & 12.0 \\
\hline Dock Builder & . 3,578 & 0.0 \\
\hline Electrician & $2,042,690$ & 16.1 \\
\hline Iron Worker & $1,447,257$ & 11.4 \\
\hline Laborers & $1,428,556$ & 11.3 \\
\hline Millwrights & 189,303 & 1.5 \\
\hline Operating Engineers & 950,505 & 7.5 \\
\hline Painters & 223,764 & 1.8 \\
\hline Pipefitters & $3,510,508$ & 27.6 \\
\hline Plumbers & 750 & 0.0 \\
\hline Roofers & 14,042 & 0.1 \\
\hline Sheet Metal Workers & 138,163 & 1.1 \\
\hline Teamsters & 193,330 & 1.5 \\
\hline TOTAL FOR PLANT & $12,680,000$ & 100.0 \\
\hline
\end{tabular}


Table 5-7. Staff Requirements for LWR Plant*

\begin{tabular}{|c|c|}
\hline AREA & STAFF \\
\hline \multicolumn{2}{|l|}{ Plant Manager's Office } \\
\hline Manager & 1 \\
\hline Assistant & 1 \\
\hline Quality Assurance & 3 \\
\hline Environmental Control & 3 \\
\hline Public Relations & 1 \\
\hline Training & 2 \\
\hline Safaty & 3 \\
\hline Administrative Services & 16 \\
\hline Health Services & 3 \\
\hline Security & 56 \\
\hline SUBTOTAL & 89 \\
\hline \multicolumn{2}{|l|}{ Operations } \\
\hline Supervision (excluding shift) & 2 \\
\hline Shifts & 33 \\
\hline EUETOTAL & 35 \\
\hline \multicolumn{2}{|l|}{ Maintenance } \\
\hline Supervision & 8 \\
\hline Crafts & 16 \\
\hline Peak Maintenance Annualized & 55 \\
\hline SUBTOTAL & 79 \\
\hline \multicolumn{2}{|l|}{ Terhnisal and Enginecring } \\
\hline Reactor & 1 \\
\hline Radiochemical & 2 \\
\hline Instrumentation and Controls & 2 \\
\hline Performance, Reports and Technicians & 17 \\
\hline SUBTOTAL & 22 \\
\hline TOTAL STAFF & 225 \\
\hline
\end{tabular}

* Single unit 701-1300 MWe 


\subsection{OPERATING STATISTICS AND ANNUAL GENERATION}

Past experience indicates that a $70 \%$ availability is reasonable for large nuclear and fossil-fueled power plants. The actual data studies were from nuclear and coal-fired baseload units $400 \mathrm{MW}$ and larger in nameplate capacity. For analytic purposes, the individual units were categorized by their size, vintage, and primary fuel burning capabilities.

The four primary utility industry measures of powerplant performance are capacity factor, availability factor, equivalent availability, and forced outage rate. The capacity factor measures the power generated by the unit versus its maximum dependable capability to produce power. The availability factor establishes only the percentage of time the unit was capable of producing power. The equivalent availability adjusts the availability factor for partial outages or deratings of the unit. The forced outage rate defines that percentage of time the unit was forced out of service due to equipment or operational malfunction. Collective review of these four indices is often taken as the measure of a unit's performance.

No single index tells the overall performance story for a unit. The annual Availability Factor establishes only the percentage of time during the year the unit was capable of producing power. This includes time when the unit was capable of producing power but was not in service because more economical units were being utilized. Thus, the Availability Factor does not measure the ability of a unit to operate at a specific power level when called. upon by the utility. Rather, it measures only the unit's capability to produce at a power level ranging from 0 to $100 \%$. The Equivalent Availability provides an adjustment to the Availability Factor by factoring in the effect of partial deratings (losses in MW output capability) due to partial forced and scheduled outages. The Equivalent Availability is essentially "equivalent to" the percentage of the year during which the unit was available for operation at full capacity. The Equivalent Availability, however, provides no measure of the effect of full forced outages or actual megawatts generated by a unit. These unit performance parameters are measured by the Forced Outage Rate and Capacity Factor. 
Typically, a large nuclear station, such as the type characterized here, would be placed first or at least close to first in the utility's loading order. Thus, it would be little affected by the customer's demand, since it would serve to satisfy part of the minimum customer load. However, a factor of .97 has been applied to the calculated plant availability to simulate a small reduction in plant operation due to inadequate customer demand.

Scheduled maintenance and affecting outages for large nuclear facilities vary from 4 to 8 weeks per year, and recent forced outage rates range from 5 to 20 percent. Here, 8 weeks of maintenance and refueling and a 15 percent forced outage rate is used for conservation to determine unit availability. Thus, plant availability is determined:

$$
\text { Plant Availability }=\frac{52-8}{52} \times(1-.15) \times 100 \%=72 \%
$$

Adjusting for customer demand reduction results in:

Capacity Factor $=(72 \%)(.97)=70 \%$

At this sapacity fartor, the reference 1250 MWe LMFBR facility would generate $7.665 \times 10^{9} \mathrm{kWh} / \mathrm{yr}$. 


\subsection{COST CHARACTERIZATION (LMFBR)}

The Energy Economic Data Base (EEDB) report prepared for DOE by United Engineers and Constructors details the base capital costs estimated for the 1250 MWe reference liquid metal fast breeder reactor power plant. Direct and indirect capital costs presented in the EEDB are on a consistent January 1 , 1978 dollar basis. They are for the 1390 MWe (3800 MNt) plant which provided much of the basis for the physical system characterization presented in the previous section.

\subsection{DIRECT CAPITAL COSTS}

The EEDB costs have been appropriately adjusted to reflect reduced power levels and flow rates incorporated into the 1250 Me reference liquic metal fast breeder reactor'system.' Specifically, the major modifications that affect the reference system's capital costs (as compared to the 1390 MWe EEDB design) include a $10.1 \%$ reduction in the following system component capacities and design characteristics:

1. Sodium coolant flow through reactor vessel

2. Steam flow through steam generators and turbines

3. Turbine shaft power, generator output, net plant capacity, and heat rejection system

Base direct capital cost includes the costs of all materials, components, structurce and associated direct craft labor necessary to construct the reference facility at the plant site. Delivered costs for components, structures and materials are used. Base indirect costs include site temporary construction facilities, payroll, insurance, and taxes, and other construction services, such as home and field office expenses, field job supervision, and engineering services. Specilically cxcluded from the base construction cost estimate are several items that are sensitive to the particular policies and preferences of the individual utility, and the specific plant site and prevalling economic factors being considered. These exclusions include the following list of items. 
1. Owner's Costs - Consultants, Site Selection, etc.

2. Federal, State and Local Fees, Permits and Taxes

3. Interest on Capital Construction Funds

4. Price Escalation during Construction

5. Contingency Funds

6. Owner's Discretionary Items - Switchyard and Transmission Costs, Waste Disposal Costs, Spare Parts, and Initial Fuel Supplies

We reviewed the cost estimates made in the EEDB for the 1139 MWe reactor design and where approprlate adjusted the costs using the capacity ratio/ exponent estimating technique. This technique, which is gencrally decepted by the electric power generation industry for making cost estimate modifications, uses the following equation to adjust component costs for small to moderate change component capacity:

Cost of Component $B=$ Cost of Component $A \times\left(\frac{\text { Capacity of } B}{\text { Capacity of } A}\right)^{\alpha}$

where component $A$ and Component $B$ are of similar design and performance, differing only in the size or capacity, and where a 1 s given by the following:

Account

21

22

23

24

25

26

\section{Descrlpeton}

Land and Land Righes

Structures and Improvements

Reactor Plant Equipment

Turbine Plant Equipment

Electric Plant Equipment

Miscellancous Flant Equipment

Condenser Heat Rejection System
Cost Estimating Exponent (i)*

Not Applicable

.20

.40

.85

.37

.20

.50

Table 5-8 shows the original EEDB cost estimate by "2-digit" accounts. The applicable cost estimating factors and the resulting 1250 WWe reference

\footnotetext{
* Argonne National Laboratory estimate based on light water reactor cost estimating exponents.
} 
system cost estimates are also shown. Costs for land would not vary measurably for the small incremental plant capacity considered here. Thus, this account has been assigned a cost estimating factor of unity; the land costs shown assume the use of a 500-acre site valued at $\$ 4,480$ per acre.

Table 5-8. Estimated Direct Capital Costs for 1250 MWe Liquid Metal Fast Breeder Reactor Reference System (January 1, 1978 Dollars)

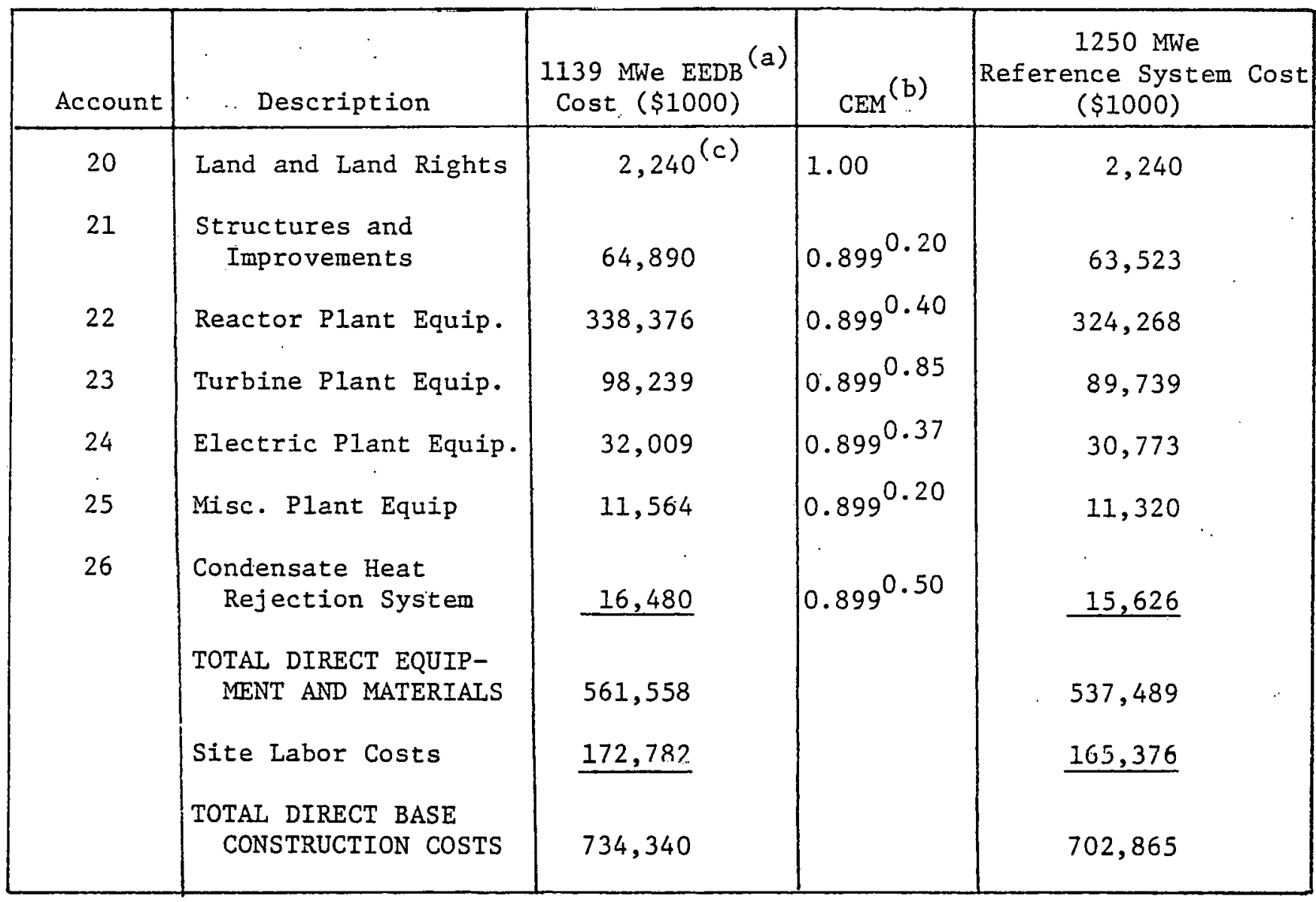

(a) EEDB, Energy Economic Data Base.

(b) CEM, Cost Estimating Multiplier, see text for discussion.

(c) Assumes 500 acres at $\$ 4,480$ /acre. 
Average site labor costs for the 1390 MWe EEDB facility are estimated from approximately 13.25 million man-hours at a craft averaged cost of $\$ 13.04$ per man-hour. Direct field labor requirements and costs have been assumed to be directly proportional to the equipment and materials costs. Resultant direct craft man-hours for the reference facility are thus estimated to total 12.68 million man-hours, or over $\$ 165$ million.

\subsection{INDIRFC.T CAPITAL COSTS}

Indirect capital costs which are assoclated. whll the construction of large liquid metal fast breeder reactor power plant, would be relatively insensitive to the plant capacitles used in the EEDB and as the raference system described here. Thus, except for payroll related expenses, indirect capital costs for the 1250 MVe reference liquid metal fast breeder reactor plant have been taken to be the same as those for the EEDB 1390 MWe plant. Construction payroll, insurance, and taxes (as well as fleld job supervision costs) were assumed to be proportional to the reference system direct field labor costs. This assumption reduced the Construction Services Account (非1) by $\$ 1310$ thousand and reduces the Field office Engineering and Services Account (\#94) by $\$ 1055$ thousand over those costs est1mated in the EEDB.

Indircet capital costs summarized in Table 5-9 at the "2-digit" account level, total $\$ 262,590,000$. These costs are about $37 \%$ of Llie direct capital cost estimated for the reference liquid metal fast breeder reactor system. These costs are more than twice the indirect costs associated with coal burning facilities for similar capacities. Safety and inspection requirements are a major contributor to this factor.

- Table 5-9. Estimated Indirect Capital Costs for 1250 MWe Liquid Metal liast Breeder Reactur Raference syatem (Jan. 1, 1978 Dollars)

\begin{tabular}{|c|c|c|}
\hline \multirow{2}{*}{ Account } & Description & $\begin{array}{c}1250 \text { MWe Reference } \\
\text { System Cost (\$1000) }\end{array}$ \\
\hline 91 & Construction Services & 89,690 \\
92 & Home Office Engineering and Services & 136,300 \\
93 & Field Office Engineering and Services & 36,600 \\
& TOTAL INDIRECT CAPITAL COSTS & 262,590 \\
\hline
\end{tabular}




\subsection{OPERATION AND MAINTENANCE COSTS}

Annual operation and maintenance (O\&M) costs for the 1250 MWe reference liquid metal fast breeder reactor facility have been estimated. This data is based on cost estimating relationships in a recent Oak Ridge National Laboratory (ORNL) document entitled, "A Procedure for Estimating Nonfuel Operation and Maintenance Costs for Large Steam Electric Power Plants." Data is available in the EEDB.

Generally, O\&M costs for a nuclear power plant may be considered to be composed of six cost categories. O\&M costs may be either fixed costs, not dependent on annual generation, or variable costs which are proportional to generation level. The six cost categories considered here include: Plant Staffing, Maintenance Materials, Plant Supplies and Expenses, including radioactive waste disposal, Nuclear Liability Insurance and Inspection Fees, Interim Replacements, and Administrative and General Expenses.

Plant staffing costs are based on the 225-person plant staff described earlier and assumes a cost of $\$ 22,000$ per person per year. Maintenance materials are estimated to be $230 \%$ of the maintenance staff costs ( 79 persons) for large LMFBR generation plants and also assumed to be insensitive to plant capacity factors. Thus, they are considered all fixed expenses. Fixed supplies and expenses, which include makeup chemicals lubricants and auxiliary fuels, as well as offsite contract services, radioactive waste management (exclusive of fuel) and nonradioactive waste management has been estimated in the EEDB report to be 5.0 million per year with a variable component of $0.05 \mathrm{mills} / \mathrm{kWh}$. Nuclear liability insurance and inspection fees are estimated at $\$ 408,000$ per year. Approximately $75 \%$ of this amount is for private and Government nuclear liability insurance. Administrative, overhead, and utility home office general expenses, which are associated with the reference facility, are estimated by ORNL to be $15 \%$ of the combined staff costs and fixed components of the materials and supplies costs. This compares to $10 \%$ of the same costs components for a conventional coal burning facility. The increase primarily results from the larger amount of recordkeeping and safety related administrative cost necessary for the nuclear facility. Table 5-10 summarizes the O\&M costs for the reference liquid metal fast breeder reactor facility. 
Table 5-10. Annual Operation and Maintenance Costs-1250 MWe Reference Liquid Metal Fast Breeder Reactor Facility @ 70\% Capacity Factor

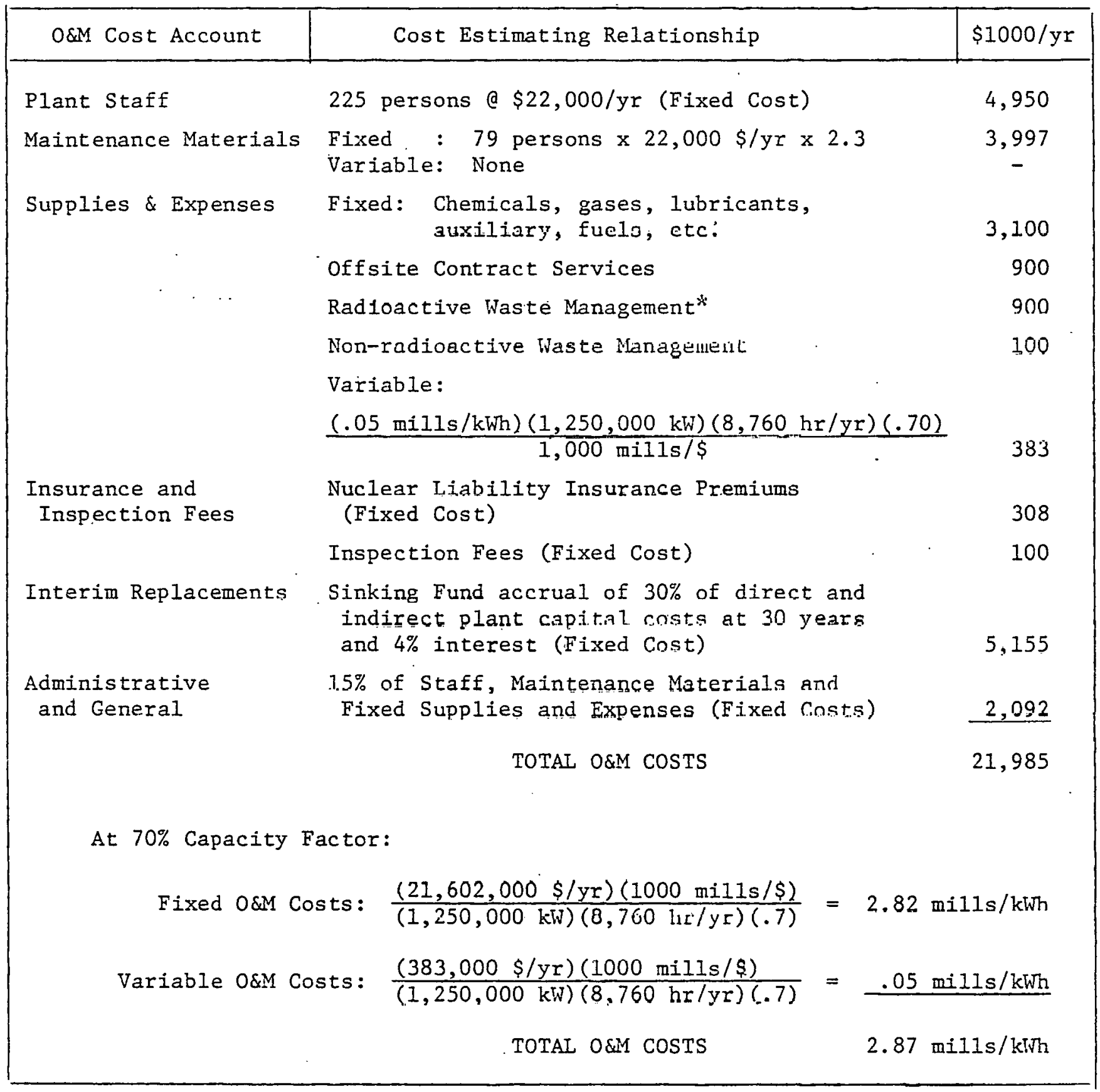

*Includes materials, packing, 1000 miles transportation and final disposal costs. 
Total annual costs for nonfuel O\&M are estimated at $\$ 21,985,000$ or 2.87 mills/kWh for a plant operating at a 70\% capacity factor. Almost all of the $O \& M$ costs are fixed expenses, $2.82 \mathrm{mills} / \mathrm{kWh}$, with only a small fraction considered variable costs, $1.05 \mathrm{mills} / \mathrm{kWh}$. 


\subsection{LMFBR FUEL CYCLE}

The nuclear-fuel cycle for LMFBRs is shown below. The initial feed materials consist of plutonium (obtained from the reprocessing of fuel from light water reactors) and depleted uranium (which results from the enrichment of the U-235 content of natural uranium). The plutonium would be converted to an oxide $\left(\mathrm{PuO}_{2}\right)$ at the reprocessing plant. The uranium, as uranium hexafluoride $\left(U_{6}\right)$, would be converted to an oxide $\left(U_{2}\right)$ at the fuel-fabrication plane. Plulunium dioxide and uranjum dioxide would be combined at the fuel-fabrication plant and falricated into mixed oxides for

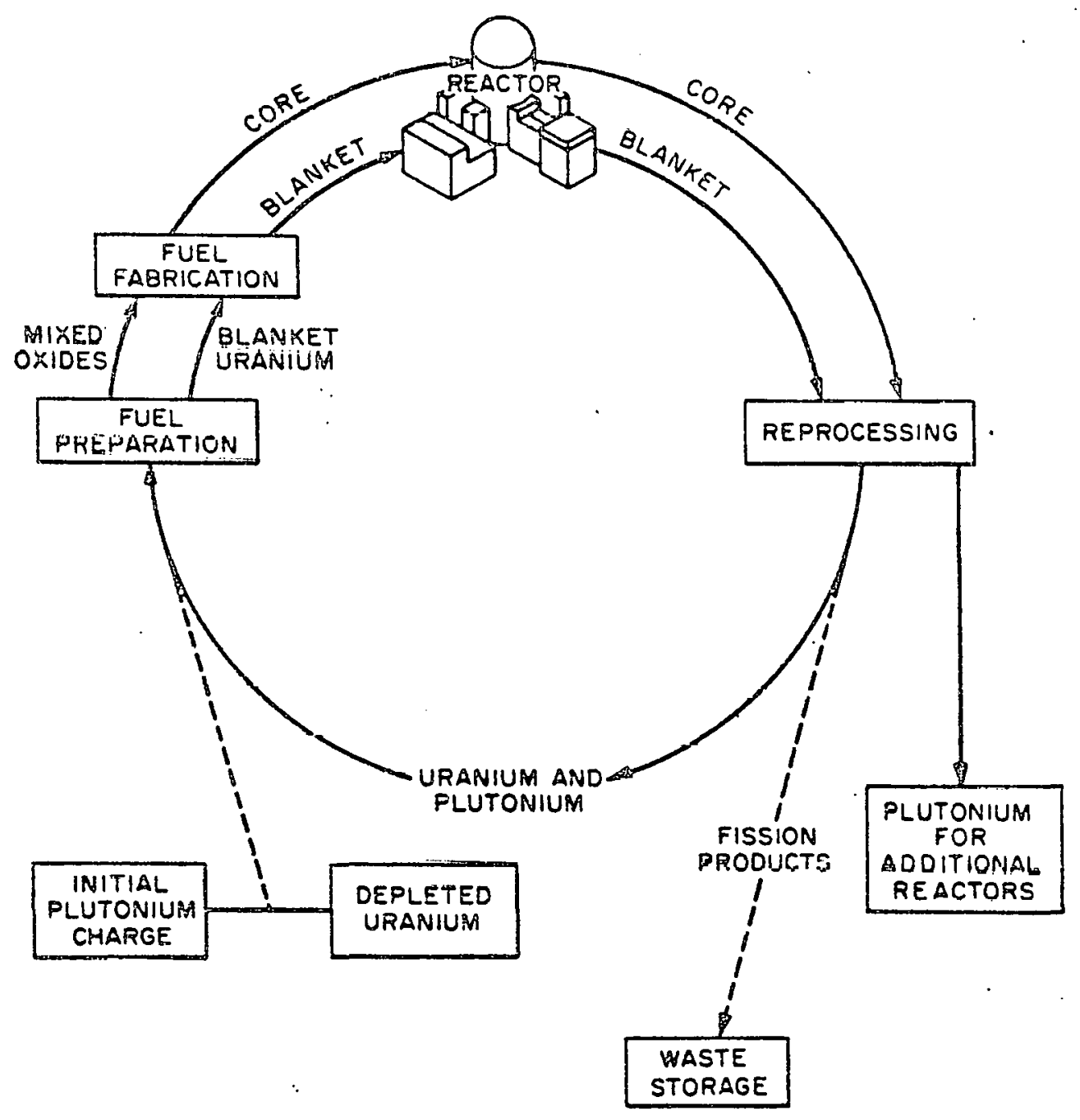

Figure 5-5. Nuclear-fuel Cycle for LMFBR 
the core fuel. Uranium dioxide would also be fabricated into pellets for the axial and radial blankets of the reactor. After exposure in the reactor, the irradiated fuels would be stored at the reactor for up to 1 year. After storage at the reactor, the irradiated fuel is shipped in shielded casks to the reprocessing plant, where the plutonium, uranium, and fission products would be chemically separated. The separated fission products would be shipped to a Federal waste-storage facility, and the plutonium would be recycled as fuel. The recovered uranium could be either stored or recycled into the mixed oxide or blanket $\mathrm{UO}_{2} \cdot$ Depleted uranium would be used for makeup for the uranium that is either converted to plutonium in the reactor, lost as scrap in the processes, or stored. A material flowsheet for this fuel cycle is given below.

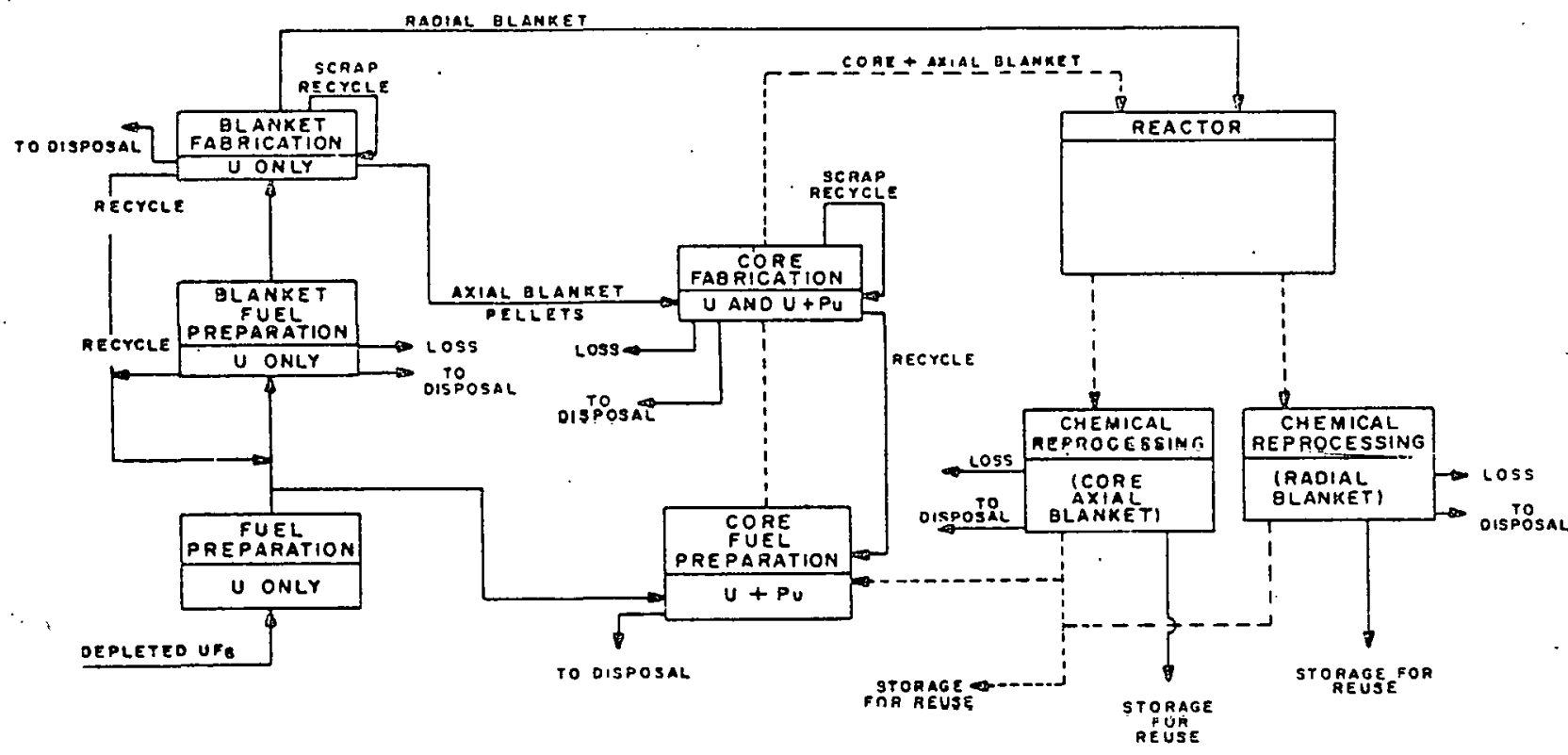

- FlOW OF MATERIAL COMTAINING Pu

Figure 5-6. Material Flowsheet for LMFBR 
The effluents and emissions from the LMFBR fuel cycle would be the same as for the LWR cycle--until the cycle had matured with the reprocessing of the spent fuel. With the mature fuel cycle, the following sections present the only differences (additions) between the LMFBR and LWR cycle.

7.1 AIR EMISSIONS $(4,5)$

Chemical

$\mathrm{SO}_{\mathrm{X}}$

NO $x$

$\mathrm{HC}$

$\mathrm{CO}$

Particulates

$\mathrm{F}^{-}$

$\mathrm{Cl}^{-}$

Radiolegical

Uranium

Tr1tium

$\mathrm{Kr}-85$

I-129

$I-13 i$

Other Fission Products

Transuranics

C-14
Tons/Yr

5.76

23.28

.52

.52

.63

.05

$6.28 \times 10^{-4}$

Curies/Yr

$3.66 \times 10^{-5}$

$1.75=10^{4}$

$3.92 \times 10^{5}$

$2.88 \times 10^{-2}$

.78

.17

.02

23.02

The Purex process is the fuel reprocessing process assumed. In this process, the fuel is dissolved and chemically separated. Airborne effluents normally released from the facility pass through the off-gas treatment and filter systems. 
7.2 LIQUID EFFLUENTS $(4,5)$

\section{Chemical}

$\mathrm{SO}_{4}$

$\mathrm{Cl}^{-}$

$\mathrm{Na}^{+}$

-
Tons/Yr

.02

.09

.02

.47 curies/yr

7.3 SOLID.WASTES $(4, .5)$

Other than HLW

Solid residuals to be disposed of include undissolved fuel element parts.

7.4 WASTE HEAT

The reprocessing of LMFBR fuel results in the generation of $7.32 \times 10^{10}$ Btu/yr of waste heat for a 1250 MWe facility.

\subsection{RESOURCE REQUIREMENTS}

Temporarily committed undisturbed area: 26.2 acres

Temporarily committed disturbed area : 3.4 acres

Permanently comnitted

: .1 acre

Overburden moved

: 104,640 tons 


\section{REFERENCES}

1. United Engineers and Constructors, Inc., Satellite Power System and Alternate Technology Characterization, UE\&C-ANL-790831, 1979.

2. Atomic Energy Commission, Proposed Final Environmental Statement Liquid Metal Fast Breeder Reactor Program, WASH-1535, 1974.

3. Department of Energy, Interim Report on the Performance of 400 Megawatt and Larger Nuclear and Coal-Fired Generating Units, DOE/ERA-0007, 1978.

4. Westinghouse Electric Company, Environmental Report for Operating License, N.R.C.

5. Atomic Energy Commission, "Environmental Survey of the Uranluw Fut Cycle", WASH-1248; April, 1974. 
SECTION 6. CENTRAL STATION PHOTOVOLTAIC: 


\section{CENTRAI STATION PHOTOVOLTAIC}

\subsection{INTRODUCTION}

The reference photovoltaic power plant is a nominal $200 \mathrm{MW}$ size. There is no economy of scale beyond the $200 \mathrm{MW}$ size as there is in conventional thermodynamic power plants. The plant characterization provided here assumes that progress in solar cell technology has resulted in high efficiency (19,3\%) cells which are fabricated directly to rectangular shape. The cell cost has been projected for the year 2000 to be $\$ 35 / \mathrm{m}^{2}$, which is much less than current costs of about $\$ 1000 / \mathrm{m}^{2}$.

The solar photovoltaic power plant is the earth bound counterpart of the SPS. It uses the same advanced solar cell technology. It does not store , energy. Due to the fact that the solar photovoltaic power plant is earthbound, there are differences. The solar photovoltaic power plant on earth has a variable output due to the diurnal sunlight cycle and an erratic patter $\ddot{n}$ of sunlight loss due to bad weather (clouds, fog, haze, etc.). The connection to the power grid on earth is straightforward, involving direct electrical connection.

The solar photovoltaic power plant supplies power to the grid on an "as available" basis. The grid may have storage in the form of batteries, flywheels, superconducting magnets, pumped hydroelectric, or compressed air storage; or it may have virtual storage in the form of hydroelectrical plants which are used for peaking. The grid treats the availability of electric power from the solar photovoltaic plant as a variation in the amount of power which must be supplied from the other sources.

The solar photovoltaic plant uses a large array of solar cells mounted on tilted frames pointed at the sun to generate high voltage d, $c$. The high voltage d.c. is then converted to high voltage a.c. and fed through transmission lines to the grid, just as any other power plant, operates.

Although large land areas eeem to be covered by the solur photovoltaic power plant, the areas normally required for the mining, processing, and transporting of coal for a coal fired plant can be much larger over the lifetime of the plant.

It should be noted that operation of a solar photovoltaic power plant involves negligible environmental impact other than the plant land area. 


\subsection{GENERAL PLANT DESCRIPTION}

The nominal 200 MW Photovoltaic Power Plant requires approximately 4.022 $\mathrm{km}^{2}$ of land ( $3042 \mathrm{~m} \mathrm{E}-\mathrm{W}$ by $1322 \mathrm{~m} \mathrm{~N}-\mathrm{S}$ ). The site includes a fenced-in perimeter setback of $65 \mathrm{~m}$ and 8 identical $25 \mathrm{MW}$ modules. These modules are in two $\mathrm{N}-\mathrm{S}$ rows of 4 modules, each of which is separated by a $20 \mathrm{~m}$ access road. Each module consists of two rectangular sectors ( $693 \mathrm{~m} \mathrm{E}-\mathrm{W}$ by $283 \mathrm{~m} \mathrm{~N}-\mathrm{S}$ ), A $60 \mathrm{~m}$ $\mathrm{N}-\mathrm{S}$ access and maintenance road separates the two sections and accommodates a $27 \mathrm{~m} \times 55 \mathrm{~m}$ converter station. The converter station is comprised of a converter/control building, a switchyard for incoming d,c,-array voltage, and an a.c.-transformer and switchyard to transmit the intermediate voltage a.c. to the Plant Transformer/Control Station. Product electricity from each module is gathered at this central station and transformed to high-vnitage power that is compatible with utility line voltages. Plant controls and maintenance activities are housed in a $26 \mathrm{~m} \mathrm{x} 20 \mathrm{~m}$ building which is located midway on the northern border of the site. The collected d.c. power and transmitted a.c. power are both underground and routed along the access and maintenance roads. The plot plan is shown in Figure 6-1. 


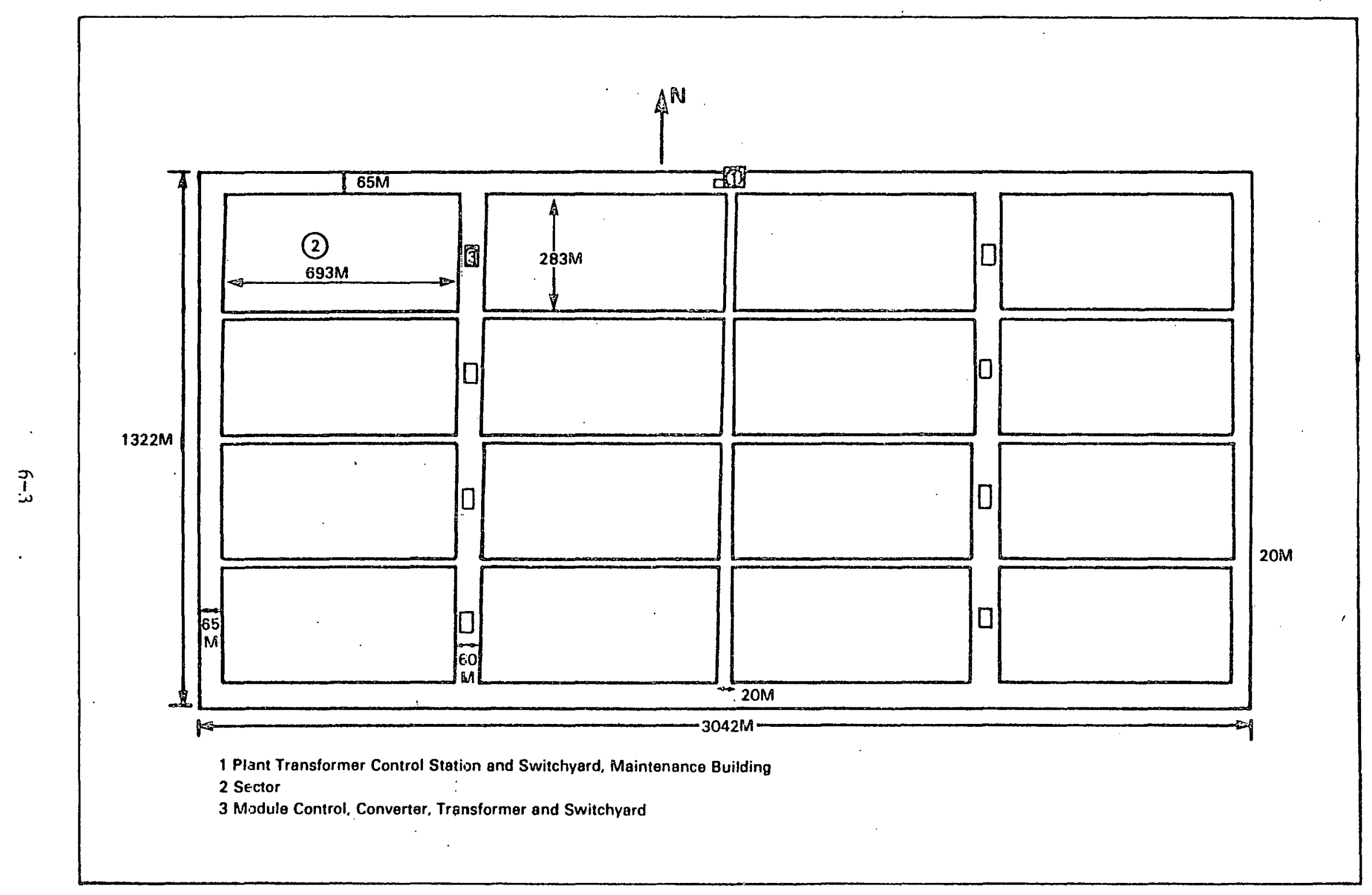

Figure 6-1. Solar Facility Plot Plan 


\subsection{CONVERSION CYCLE DESCRIPTION}

\section{$3.125 \mathrm{MW}$ MODULE}

Solar insolation received by the array $\left(100 \mathrm{MW} / \mathrm{cm}^{2}\right.$ or $0.0929 \mathrm{~kW} / \mathrm{ft}^{2}$, ANI, $28^{\circ} \mathrm{C}$ ) for peak design is reflected ( $\left.8 \%\right)$, internally consumed $(1-1 / 2 \%)$ and absorbed (90.5\%). The spectrum absorbed is converted to d.c. electricity with nominal efficiency (19.0\%). However, the cells are heated by the solar absorption so that the temperature of the arrays averages $45^{\circ} \mathrm{C}$ over the year. This reduces the efficiency by $8.4 \%$. Direct current interconnections for cells, panels, and rows have electrical resistance as does the d.c. bus which delivers the energy to the d.c./a.c. converter. At the converter, additional losses are incurred and auxiliary power must be supplied. We have asșumed a $2 \%$ loss at this site, based up.on Figure E-19 and Table E-6 (P. E-38) of the EPRI-ER-685 report (Reference 2), resulting in a net $14.21 \%$ efficiency at the converter fence. Table 6-1 illustrates the cycle described above.

\subsection{CENTRAL PLANT}

The intermediate voltage a.c. from the modules is transported via underground bus to the central station for conversion to high voltage a.c. $I^{2} R$ losses are incurred in the transmission and step-up transformer. We have assumed a 1.3\% loss in efficiency because the referenced EPRI report indicates approximately $0.3 \%$ of tull load for transmission and a range under $1 \%$ for stepup transformer losses. Power at the Central Plant Transformer/Control Station will be, at design conditions, about 197.3 MW at an overall efficiency of 14.02\%. Within each module, there are 122,256 panels $(61 \times 244 \mathrm{~cm}$ ), each containing 400 silicon photovoltaic cells $(6 \times 6 \mathrm{~cm})$, for a total of $48.9 \times 10^{6}$ cells per module or approximately $391 \times 10^{\circ}$ cells per plant. The panels in each sector are adjoined in three rows of $283 \mathrm{E}-\mathrm{W}$ with 72 parallel rows $\mathrm{N}-\mathrm{S}$, tilted south nominally $30^{\circ}$ from the horizontal on the $244 \mathrm{~cm}$ edge. The para11 el rows are separated by approximately $2.32 \mathrm{~m}$ to minimize shadowing. The panel and row arrangement is shown in Figure 6-2.

Each vertical set of three panels are connected in parallel and 283 files of 3 panels are in series to form a row which is in series with the adjacent row to form $\pm 4809 \mathrm{v}$. Thirty-six pairs of rows are in parallel to form a sector. Two sectors are parallel to form a module.

Cells on the panels and panels on the array are connected in series across the array from east to west, and parallel-connected up the array from north to 
Table 6-1. 25 MW Solar Photovoltaic Central Plant Array Parameters*

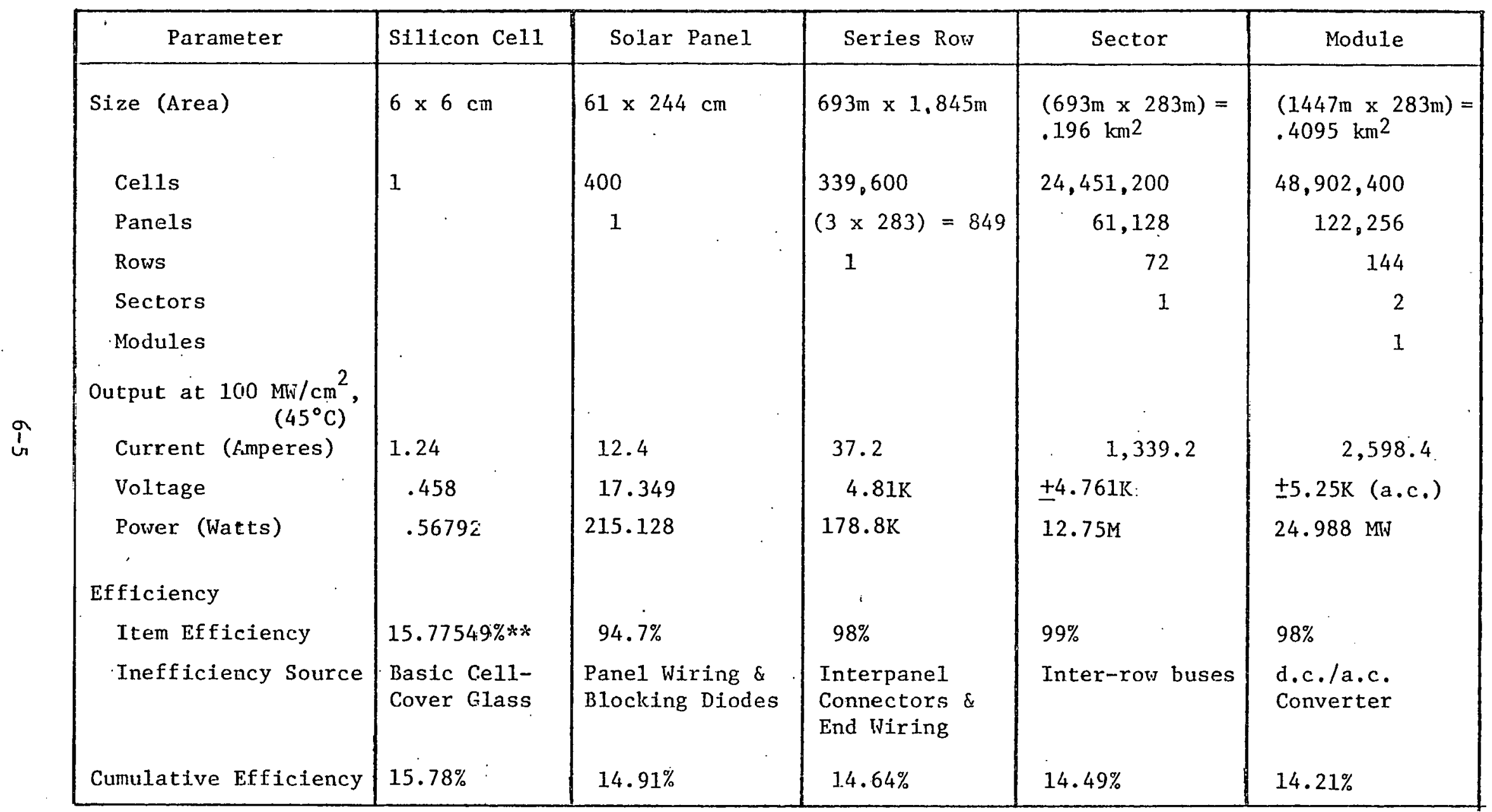

$*$ (Modeled somewhat after Table K-2 Pk-15 EPRI-ER-685)

$* *$ Solar Ce11 Efficiency $19.03 \%$ Bare at AM1 $\left(28^{\circ} \mathrm{C}\right)$

Total Module Cell Area $=.176 \mathrm{~km}^{2}$

Panel Area $=.182 \mathrm{~km}^{2}$ 


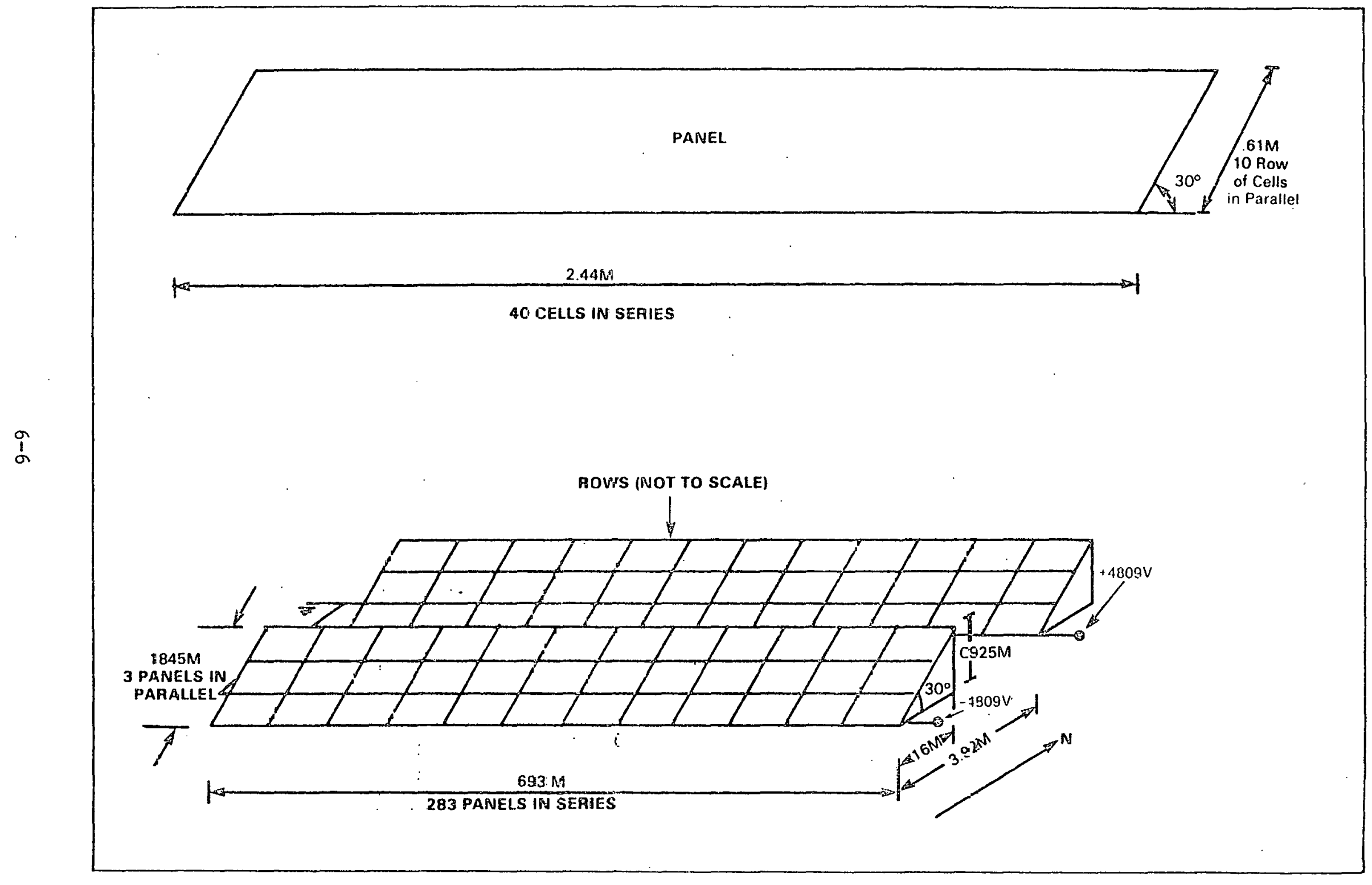

Figure 5-2. Solar Panel Arrangement 
south. This arrangement minimizes interrow shadow effects. The upper shadowed series cells and panels always develop full voltage. Shadowed parallel strings on the lower edges of the array reduce the available current.

A nominal $30^{\circ}$ tilt facing south has been assumed for the array. The actual tilt chosen for a specific location would be equal to the latitude value in degrees, approximately 10 degress less to maximize annual energy collection. With the $30^{\circ}$ tilt and a shadow spacing factor of 2.12 to minimize interrow shadowing, a row-to-row pitch distance of 3.92 meters is established,

The electrical and physical parameters selected and calculated above provide the central framework for a conceptual design.

Panel and cell insulation materials and values have been assumed to be adequate at the end points of the series string with voltages of \pm 4809 . It has been assumed that the lightning protection system (an array of lightning rods) will not shadow the solar cells from the sun. Diodes in panel and array circuitry provide protection against possible open and short circuit conditions. Panel/array short circuit and grounding provisions are included for personnel safety during servicing and installation, Sizing, epacing, interconnection requirements, wire length, and size have been analyzed to ensure maximum performance/cost effectiveness.

\subsection{ELECTRICAL SYSTEM DESCRIPTION}

The $200 \mathrm{MW}$ plant consists of 8 identical modules containing an a.c. output which is collected at a common switching station and transformed from medium to high voltage to match the utility transmission voltage. Each module is divided into three major levels or subsystems: (1) the array and its sonnectIng cables and main d.c. bus, (2) the converter station, and (3) the medium voltage cable. The switching/transformer station is common to all 8 modules, each rated at $25 \mathrm{MWe}$.

A d,c. circuit breaker is provided at the d,c. input terminals of the converter station. This is the only electrical equipment (excluding the array and cells) that requires development effort. The d.c. breaker is used for start-up and shut-down sequencing, and for protection from faults in the converter, array, bus, or cable. High impedance ground detectors detect a ground fault in the array subsystem and initiate protective circuit interruption and annunciation of the fault. Reactors are used to smonth the d.c. current 
and reduce the ripple caused by converter commutation. Thus, harmonics on the d,c. side are confined to the converter station or reduced to a low value in the array bus and interconnections. The converter valve assembly, together with the converter transformers, is a 12-pulse bridge connected line-conmutated inverter arrangement. The load tap changer on the converter transformer is used to keep the inverter within reasonable firing angle margins for the range of operating voltage expected from the array during the wide variations in the load and in array temperature. The converter transformer rating is less than the peak output of the converter since the insulation follows a predictable cycle which permits "underrating" the transformer by taking its thermal inertia into account.

High-pass filters provide higher order $(60 \mathrm{~Hz})$ harmonic suppression and puwer faltur correction. $\Lambda t$ full lnar, the plant operales at 9 power factor, The total filter requirement is deployed in two (or three) groups to give stepped var (reactive volt-amperes) control, and reasonable power factors at light loads. An auxiliary transformer at each converter station taps converter station and array auxiliary power. The transformer is tapped to the medium voltage station bus ahead of the load break disconnect to provide auxiliary power independent of the converter operation. The most economical voltage rating for the 25 MW module slze lutulum voltage enble was daterminer to he. $34.5 \mathrm{kV}$. The cable is installed in underground ducts and consists of three shielded, jacketed, single-phase conductors, plus a ground wire,

For economic reasons, a simplified $34.5 \mathrm{kV}$ single bus, radial switching arrangement is chosen at the transformer switching station. Similarly, the single step-up transformer is a triple-rated 100/132/168 MVA OA/FA/FOA transformer that takes advantage of the transformer's thermal inertia and the predictable maximum plant load curve.

The plant electrical boundary was assumed to be the high voltage terminals of the step-up transformer, Rather than rely solely upon the single. circuit high voltage (HV) transmission circuit for plant auxiliary power, a $34.5 \mathrm{kV}$ feeder reserve source is shown, Because a utility reserve source may not be practical, considering the plant's remote location, some kind of local standby source will be required. 


\subsection{ENVIRONMENTAL IMPACTS OR RESIDUALS}

\section{I AIR}

Under normal operating conditions, no emissions are expected. A fire in the electrical transmission could release toxic materials, but such components are no different from those used in other power stations. The large land area of the solar.station provides a separation between these cormonents and thus would limit the extent of a fire. The toxic material (combustion products) which is released would thus be in smaller quantities than if the fire were in a conventional power station.

\subsection{WATER}

The requisite periodic cleaning of the array surfaces creates minor water runoff problems. However, containment of the cleaning agent prevents surface or sub-surface vater contamination, and proper site preparation and choice of contours and cleaning material should minimize this concern.

\subsection{SOLID WASTES}

Beyond minor solid wastes created by panel breakage replaccments, no solid wastes are expected to be generated. These waste materials consist of glass, silicon cells, aluminum backing, and minor amounts of sealant and substrate.

\subsection{THERMAL EMISSIONS}

The massive arrays designed to absorb as much insolation as possible may have some minor effect on daily cycles of heating/cooling from absorbed insolation relative to bare or cultivated ground, but they should not have any noticeable favorable or unfavorable impact.

\subsection{REFLECTED INSOLATION}

The reflected insolation has been estimated at some $8 \%$ (less than expected without the plant). However, the concentration of reflection by the array, as opposed to diffuse reradiation from unimproved land, could potentially be a hazard or nuisance in the early morning or late atternoon durfng the summer. This reflectance has been compared to reflection from a still lake or from glass in a vertical building, a minimal hazard generally acceptable to the public. 


\subsection{LAND USE}

The most significant impact of a $200 \mathrm{MW}$ Central Power Plant will be the removal of land from other use. As indicated earlier, some $4.022 \mathrm{~km}^{2}$ of land must be converted from other uses to serve as a platform for solar arrays, or a rounded $20 \mathrm{~km}^{2} / \mathrm{GW}$. A coal-fired controlled emission power plant is estimated to require $3.885 \mathrm{~km}^{2} / \mathrm{GW}$ but this excludes any extraneous land use such as mining processing and transporting which could require as much as $66,3 \mathrm{~km}^{2}$ (EPRI, p. $N-27)$. A gas turbine single cycle generating facility can require only $1.3 \mathrm{~km}^{2}$ for $1 \mathrm{GW}$ of capacity. 


\subsection{CONSTRUCTION AND OPERATING CHARACTERISTICS}

The $200 \mathrm{MW}$, nominal, Central Plant Solar Photovoltaic Electrical Production System.(CPS) is hypothesized as a flat-plate collector, nonstorage, contributor to the utility system grid.

\subsection{CONSTRUCTION}

This mammoth-size installation is projected to require 5 years for construction before going on stream (Reference 2). It is believed that any utility (and regulatory commission) would phase in partial capacity as it was completed, particularly with 8 identical modules that could stand independently. Given that a utility must add capacity, a 5-year wait would require other expansions that would reduce capital availability for this project. Therefore, a gradual construction program will consist of land purchase, site clearance, and road and other site construction for the central station in the first year (1995). The next four years will involve installation of $25 \%$ of the final capital equipment each year. Thus, $25 \%$ of plant capacity will be available at the end of year two, $50 \%$ at the end of year three, and so on. The complete output of the plant would thus become available at the end of the fifth year, January 1, 2000.

There do not appear to be any problems. However, we are not familiar with lead times, specifically the necessary converters and transformers required for production of sufficient cells. Early operation would generate cash flow, minimize AFDC, and minimize escalation. The first $25 \%$ capacity increment will function as a process demonstration unit, which will alleviate subsequent problems, It will also function as a training center for personnel. There will be a center for construction, and operating and maintenance practices as well. The levelled construction would, moreover, minimize the impact of high-cost, high-density progress normally found in a large project. The installation of panelized solar-arrays, at ground level, on shop-fabricated tilt-angle supports, and with simplified efficient interconnection plugging would be a simple project. The underground wiring and converter/transformer installations are also a standard "non-novel" activity and should pose no problems.

\subsection{OPERATIONS AND MAINTENANCE}

Designed without dedicated storage, the function of this plant is to maximize electric power generation, i,e, achieve the highest possible lead 
factor. EPRI (Reference 2), via GE, believes that a 3-man crew/shift plus a 2-shift technician, and 3-man daytime staff will be used for a $200 \mathrm{MW}$ plant. They also indicate that 180 additional man-weeks would be required for maintenance of the "balance of plant." The shift crews are responsible for array maintenance requirements.

For our purposes, we would suggest the following staffing (to include both $0 \& M$.

$$
\text { Staff - } 200 \text { MT CPS Solar PV }
$$

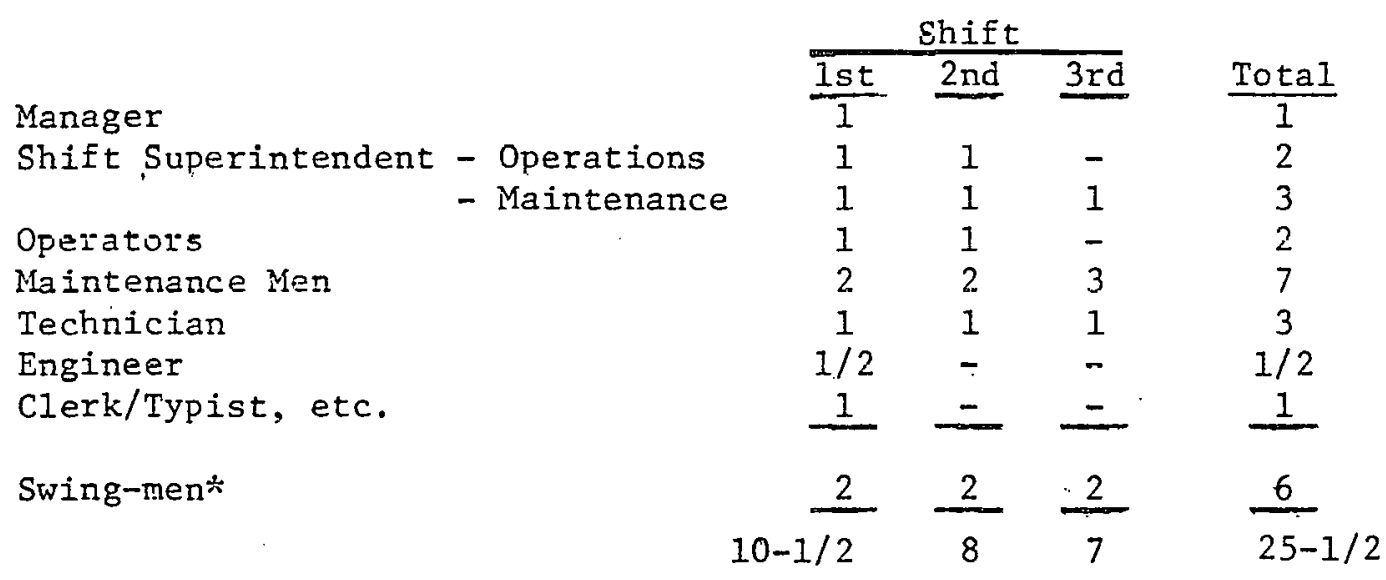

$\therefore$ To ensure 7-day operations and maintenance

\section{2 .1 Maintenance of Arrays}

PV power plant maintenance is unique with respect to the photovoltaic arrays: maintenance of reflectors, refractors, and solar panels is an uncertain area, For flat-plate panels, the encapsulation itself provides protection to the cells, but the encapsulation surface will require cleaning. The required frequency of cleaning can only be determined through experience with actual arrays in different climates, but it will probablÿ be necessary to accept some loss of transmittance or reflectance of the collectors to achieve a feasible maintenance schedule, For large arrays, it will undoubtedly be necessary to develop vehicles which can pass between the collector rows to perform the cleaning with water sprays or mechanical brushing techniques, Array support structures will require periodic painting and cleaning for corrosion prevention.

We have somewhat expanded the postulated staff because we believe that 8 modules, each with $.176 \mathrm{~km}^{2}$ of array, to be cleaned and maintained (requiring 
$208 \mathrm{~km}$ of traveling to go through the rows in each module), will call for more sizeable housekeeping. If anything, the maintenance force could be expanded to include structure, converter, and switching upkeep. Each quarterly cleaning/rinsing of the arrays (as suggested by Westinghouse) would require a 7-day/ week, 365 day/year average of $18 \mathrm{~km} /$ day or almost 11,000 panels on a daily continuous basis.

\subsubsection{Balance-of-Plant Maintenance.}

For the portion of a PV plant excluding array and array support subsystems, the maintenance effort will be relatively standard by utility criteria. The main difference compared with conventional plants will be that maintenance activities of this plant relate more closely to those of transmission and distribution facilities. The plant has a transmission/distribution character because it is deployed over a large area and has similar major elements. In addition, since array maintenance and repair is possibly a nighttime activity, array and roadway lighting with attendant lighting system maintenance requirements. is very likely.

Routine testing and preventative maintenance will be performed on a scheduled basis; fault correction and component and equipment repair and replacement will be performed as required. These plants employ passive cooling of the arrays because of the nature of the plant electrical equipment (solid state converters, conventional cables, transformers, switchgear, and auxiliary equipment), and therefore require a relatively low level of maintenance. 


\subsection{COST CHARACTERIZATION (TERRESTRIAL PHOTOVOLTAIC)}

Capital cost estimates for the 200 MWe reference Central Power Station Solar Photovoltaic Facility represent composites of cost data found in several authoritative sources and from information regarding silicon cells of SPS Concept Development documents. The designated silicon photovoltaic cells are patterned after Comsat nonreflecting cells and are valued at $\$ 35 / \mathrm{m}^{2}$. The balance of costs for the array and connecting conduits was developed based upon detailed cost data for a larger but similar system contained in the GE report, Reference 1. Power conditjoning and electric plant equipment costs are estimated based on data for a similar flat-plate system in the EPRI/GE report. Indirect costs were also derived from relationships exhibited in the EPRT/GE report.

As described in the cost characterization for other facilities, certain costs have been specifically excluded from the base cost estimates. These costs, which are sensitive to (1) the specific utility policies and preferences, (2) the particular location, and (3) the prevailing economic attitudes and environment, include:

- Owner's Costs - Consultants, site selection, construction

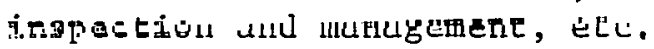

- Federal, State and local permits, fees and taxes

- Allowance for funds used during construction

- Price escalation during construction

- Allowances for contingencies

- Owner's working capital, inventory items

\section{I DIRECT CAPITAL COSTS}

The capital costs for a 200 MWe Central Power Station/Snlar Photovodtaic Facility found in Reference 2 have been appropriately adjusted to reflect the improved performance and cost characteristics of the silicon photovoltaic cells assumed in this report. The square silicon cell used herein $(6 \mathrm{~cm}$ each side) is projected to generate 0.568 Watts at a voltage of $0.458 \mathrm{~d} . c$. and current of 1.24 Amps, at an overall efficiency of $15.76 \%$ from a celi efficiency (at $28^{\circ} \mathrm{C}$ ) of $19.0 \%$ and cover-glass attentuation of $9.5 \%$ and high temperature voltage loss of $8.4 \%$. After allowing for wiring and conversion losses, the net 
efficiency into the utility transmission system is projected to be $14.02 \%$. The previously cited EPRI report used a nominal 12\% silicon cell efficiency, which represented a conservative state-of-the-art at that time. Additionally, the projected cost parameter for silicon cell technology has been modified to cost $\$ 35 / \mathrm{m}^{2}$ of silicon cells, which is consistent with assumptions made for the SPS system.

The costs of solar array panels and supporting structures were derived from the detailed structural estimates found in Reference 1 . On the basis of silicon cell area relationships, these costs were adjusted to more accurately indicate the required investment for the reference system.

Power conditioning equipment and other electric plant equipment costs are essentially derived from updating the EPRI report, with a comparison of costs included in the GE Reference 1 for corroboration.

The base direct capital costs, Table 6-2, include the costs of all materials, equipment, components, and installation labor necessary to construct the 200 MWe Solar Photovoltaic Facility on the purchased 994 acre site. The direct capital costs were assembled from the various data and updated to depict costs as of January 1, 1978, through use of 1.1365 escalation from mid-1975 and 1.0823 for mid-1976 calculated as the ratio of fourth quarter 1977 to yearly average numbers for the GNP Implicit Price Deflator index.

Direct craft labor costs were not explicitly detailed in any of the references. However, these may be estimated based on the relative fraction of labor for similar types of construction activities for other technologies. For example, labor costs make up roughly $40 \%$ of the total cost of buildings and facilities, and electrical plant costs in a coal facility. If $40 \%$ of the buildings and facilities costs, power conditioning costs, and electrical plant costs are assumed to be for labor, and if the array installation cost noted under account 22 is taken as labor, the total labor cost would be estimated at $\$ 22,276,000$ or about 1.7. million man-hours.

\subsection{INDIRECT CAPITAL COSTS}

Indirect capital costs associated with any construction project will include construction management and services, field engineering and supervision, and home office design engineering, equipment logistics, and services. 
Table 6-2. Estimated Direct Base Construction Costs 200 MWe Solar Photovoltaic Central Power Station (in January 1, 1978 dollars)

\begin{tabular}{|c|c|c|}
\hline $\begin{array}{l}\text { Account } \\
\text { Number }\end{array}$ & Construction Needs & $\begin{array}{l}200 \text { MWe Costs } \\
(\$ 1000)\end{array}$ \\
\hline 20 & Land and Land Rights 994 A \& $\$ 4,480 / \mathrm{A}$ & 4,453 \\
\hline \multirow[t]{2}{*}{21} & Buildings and Site Facilities (a) & \\
\hline & $\begin{array}{l}\text { 1. S1te Development (a) } \\
\text { 2. Structures } \\
\text { 3. Towers } \\
\text { 4. Underground Conduit } \\
\text { 5. Underground Conduit }\end{array}$ & $\begin{array}{r}2,584 \\
160 \\
240 \\
1,250 \\
1,150 \\
\end{array}$ \\
\hline \multirow{4}{*}{ ' 22} & Total Buildings and Site Facilities & 5,384 \\
\hline & Solar Array Equipment & \\
\hline & $\begin{array}{l}\text { 1. Silicon Solar Photovoltaic Cells @ } \$ 35 / \mathrm{m}^{2} \\
\text { 2. Photovoltaic Array Structures } \\
\text { 3. Array Installation }\end{array}$ & $\begin{array}{l}48,294 \\
25,250 \\
11,600 \\
\end{array}$ \\
\hline & Total Solar Array Equipment & 86,144 \\
\hline 23 & Power Conditioning Equipment (b) & 10,823 \\
\hline \multirow[t]{2}{*}{$2 / 4$} & Electric Plant Equipment (b) & 10,390 \\
\hline & TOTAL DIRECT CONSTRUCTION COSTS (c) & 117,194 \\
\hline
\end{tabular}

NOTES

(a) GE (in Reference 1), from ratio devel./site, derived at $\$ 2600 /$ A-Other materials per GE details Tables $\mathrm{K}-11, \mathrm{~K}-14, \mathrm{~K}-12$

(b) EPRI, ER-685 (Reference 2), Table G-5, p. G-7, escalated x 1.0823 (1976 average to 1-1-78 GNP Deflator)

(c) Miscellaneous Plant Equipment (Acct. No. 25) included in Account Nos. 21, 22, 23, 24. Labor coses are concained in account corals and estimated to be 1.7 million man-hours or $\$ 22,276,000$. 
Typically, these represent an estimated value of services performed and are derived from consideration of the total direct capital costs and labor costs involved in the project.

Costs for construction services (Account 91) were estimated based on. temporary construction facilities valued at $8 \%$ of the total plant costs, and payroll insurance and taxes valued at $15 \%$ of the direct labor costs. These factors result in a total construction services cost of $\$ 12,737,000$.

Home office engineering and services has been estimated to be $4.3 \%$ of the direct plant costs--similar to the fractional cost displayed in fossil fuel plant construction. Likewise, field office engineering and services was estimated at $3.6 \%$ of the direct plant costs. Table 6-3 itemizes the indirect cost estimates which total nearly $\$ 20$ million or about $17 \%$ of the plant's direct capital costs.

Table 6-3. Estimated Indirect Capital Costs for 200 inje Solar Photovoltaic Central Power Station (in January 1, 1978 Dollars)

\begin{tabular}{|c|c|c|}
\hline $\begin{array}{l}\text { Account } \\
\text { Number }\end{array}$ & Construction Needs & $\begin{array}{c}\text { Reference } \\
\text { Design Costs } \\
(\$ 1,000)\end{array}$ \\
\hline 91 & Construction Services & 10,716 \\
\hline 92 & Home Office Engineering and Services & 5,050 \\
\hline \multirow[t]{2}{*}{93} & Field Office Engineering and Services & 4,228 \\
\hline & TOTAL INDIRECT CAPITAL COST & 19,994 \\
\hline
\end{tabular}

\subsection{OPERATING AND MAINTENANCE EXPENSES}

The basic 200 MWe plant configuration used as a model for this characterization cited an operating staff of 14 people and a maintenance requirement of 180 man-weeks of cffort. To ensure full, uninterrupted operations and requisite $24 \mathrm{hr} /$ day maintenance, we plan to use additional maintenance personnel and swing shift operators. The staffing costs are estimated at an average of $\$ 22,000 /$ man-year, 
Operating supplies necessary to sustain day-to-day operations were estimated to cost $15 \%$ of the direct operating payroll. This is a common cost estimation practice. It represents office supplies, telephone and other customary expenses of operations. Maintenance supplies are established at $60 \%$ of the maintenance payroll and will include cleaning supplies, tools and equipment replacements, and parts and materials used in performing the necessary routine maintenance.

During the 30-year life of this project, equipment will break down and array structures will be damaged. An allowance must be considered for these intervening replacements. As used in the coal gasification/combined cycle characterization, a sinking fund will accumulate to $30 \%$ of total investment over the 30-year life to cover these expenses. The annual payment to the sinking fund is $\$ 783,000 /$ year.

As part of an existing utility, the reference facilities will have administrative and service function costs allocated to operations. These amount to $10 \%$ of payroll and supplies and account for administrative, personnel, legal, accounting, and other services incident to operations.

Phoenix, Arizona and Cleveland, Ohio are two examples of sites used in this review. (Boston, Massachusetts is the third example.) The sum of O\&M costs above has been assumed identical for each location. However, the cost per kilowatt hour of electricity produced will be substantially different because the two locations will vary in their net output of power. The widely differing insolation and climatological characteristics inevitably force differing plant operating factors for each location. Phoenix was carefully studied in the EPRI report and calculations resulted in a plant operating factor of $25.8 \%$, i,e., over the $8760 \mathrm{hr} / \mathrm{yr}$. Phoenix's solar photovoltaic output represented some $25.8 \%$ of that time or equivalently 2260 hours at design capacity. Unit costs of $3.8 \mathrm{mills} / \mathrm{kWh}(\$ 0.0034)$ for O\&M costs were derived on that basis.

Boston, which was also included in the report, had a calculated plant operating factor of $17.7 \%$. Insolation at the three cities is known and expressed normally in Langleys which is defined as gram-calories per square centimeter or $3.687 \mathrm{Btu} / \mathrm{ft}^{2}$. Cleveland, the other site considered, was not 
included in the EPRI report. To derive the estimated plant factor for Cleveland, the following interpretation was used:

Given: $P, O, F, \because$ is a function of insolation

$$
\begin{array}{lll}
\text { P.O.F. - Phoenix } & 28.8 \% \\
\text { P.O.F. - Boston } & 17.7 \% \\
\text { Langleys, Mean daily, - Phoenix } & 518 \\
& \text { Boston } & 301 \\
& \text { Cleveland } & 335
\end{array}
$$

To Find: P.O.F, - Cleveland

1. $\frac{\text { Phoenix }}{\text { Boston }}=\frac{25.8 \%}{17.7 \%}=\left(\frac{518}{301} \text { Langleys }\right)^{\mathrm{K}}$

2. Cleveland P.O.F. $=\left(\frac{335}{301} \text { Langleys }\right)^{0.695} \times 17.7 \%$ Boston P. $0 . F$.

Cleveland P.O.F. = $19.1 \%$

$\therefore$ P.O.F. - plant operating factor

The annual O\&M cost for solar photovoltaic power generation in Cleveland is estimated, on this basis, at 5.1 mills or $\$ 0.0051 / \mathrm{kWh}$. Table $6-4$ illustrates the estimated annual operational expenses. 
Table 6-4. Estimated Annual Operating and Maintenance Costs 200 MVe Reference Solar Photovoltaic Central Power Station (in January 1, 1978 dollars)

\begin{tabular}{|c|c|c|}
\hline $\begin{array}{c}\text { O\&M } \\
\text { Account }\end{array}$ & Operating Cost Components & $\$ 1,000 / \mathrm{Yr}$ \\
\hline Plant Staff & $25-1 / 2$ persons @ $\$ 22,000 /$ yr (Fixed Cost) & 561 \\
\hline Supplies \& & Operating @ 15\% Oper. Payroll & 28 \\
\hline Expenses & Maintenance @ $60 \%$ Maint, Payrol1 & 224 \\
\hline $\begin{array}{l}\text { Interim } \\
\text { Replacements }\end{array}$ & $\begin{array}{l}\text { Sinking Fund Accrual of } 30 \% \text { (Direct } \& \\
\text { Indirect Capital Costs over } 30 \text { year life } \\
\text { at } 4 \% \text { "real" interest rate }\end{array}$ & 783 \\
\hline \multirow[t]{2}{*}{$\begin{array}{l}\text { Admin, \& } \\
\text { General }\end{array}$} & 10\% of peyroll plus supplies & 02 \\
\hline & TOTAL ESTIMATED O\&M COSTS & 1,678 \\
\hline \multicolumn{3}{|c|}{ Unit $O \& M$ costs in mills/kWh } \\
\hline Phoenix & $(445,914 \mathrm{MW} \mathrm{hr} / \mathrm{yr})$ (a) & 3.8 \\
\hline Cleveland & $(330,114 \mathrm{MH}$ hr/yr) (b) & 5.1 \\
\hline
\end{tabular}

NOTES

(a) Phoenix plant capacity factor $=25,8 \%$ per Table H-I, p. H-2, EPRI ER 685 , Reference 2,

(b) Cleveland plant capacity factor $=19.1 \%$ from interpolation, Table $\mathrm{H}-1$ for Boston/Phoenix, Raference 2.

$$
\begin{aligned}
& \frac{\text { Phoenix }}{\text { BustuI }}=\frac{25.8 \%}{17.7 \%}=\left(\frac{518}{301}\right)^{0.695} \\
& \left(\frac{\text { Cleveland }}{\text { Boston Langley/day })=\left(\frac{335}{301}\right)^{0.695} \times 17.7=19.1 \%}\right.
\end{aligned}
$$




\section{REFERENCES}

1. "Conceptual Design and System Analysis of Photovoltaic Systems, Final Report, Volume II Appendices, Report No. ALO-3686-14." General Electric, Space Division. March 19, 1977.

2. "Requirements Assessment of Photovoltaic Power Plants in Electric Utility Systems, ER-685, Volume 2, Research Project 651-1." General Electric, Electric Utility Systems Engineering Department. June 1978. 


\section{SECTION 7. MAGNETIC CONFINEMENT FUSION}




\section{MAGNETIC CONFINEMENT FUSION}

\subsection{INTRODUCTION}

The characterization of a fusion power plant presented here is based on the NUWMAK power plant design developed by the University of Wisconsin Fusion Engineering Program of the Nuclear Engineering Department and published in March, 1979. The NUWMAK power plant produces electricity through a boiling water reactor (BWR) power cycle with heat supplied by a Tokamak fusion reactor. One plant produces $660 \mathrm{MWe}$ net. The power facility characterized here consists of two NUWMAK reactors and produces a net power of 1320 MWe operating at an overall thermal efficiency of $31.5 \%$.

The NUWMAK is a newer and more realistic design than the UWMAK series developed by the University of Wisconsin. The design philosophy in NUWNAK has been to make mechanical design and maintainability easier. The power density in NUWMAK is increased to about $10 \mathrm{~W} / \mathrm{cm}^{3}$ as compared to 0.5 to $2 \mathrm{~W} / \mathrm{cm}^{3}$ in earlier designs. The NUWMAR design does not use a divertor to control impurities, thereby considerably simplifying the reactor design and allowing easier access and maintenance. Instead, impurity control in NUWMAK is achieved through a system using gas puffing (which also serves to partially fuel the reactor). Heating of the plasma is achieved via radio-frequency (RF). heating rather than by neutral-beam injection, simplifying the engineering. The reactor blanket employes phase change energy storage, reducing the need for and simplifying external energy storage systems. Titanium alloys replace stainless steel as structural materials for the first wall and blanket of the reactor, in order to increase material life under neutron bombardment and reduce the impact on mineral resources.

Figure 7-1 shows schematically the simplification in the power cycle of NUWMAK as compared to a "conventional" Tokamak power plant. Although many technical questions remain concerning the NUWMAK design, the NUWMAK design is an improvement over earlier fusion reactor designs. 


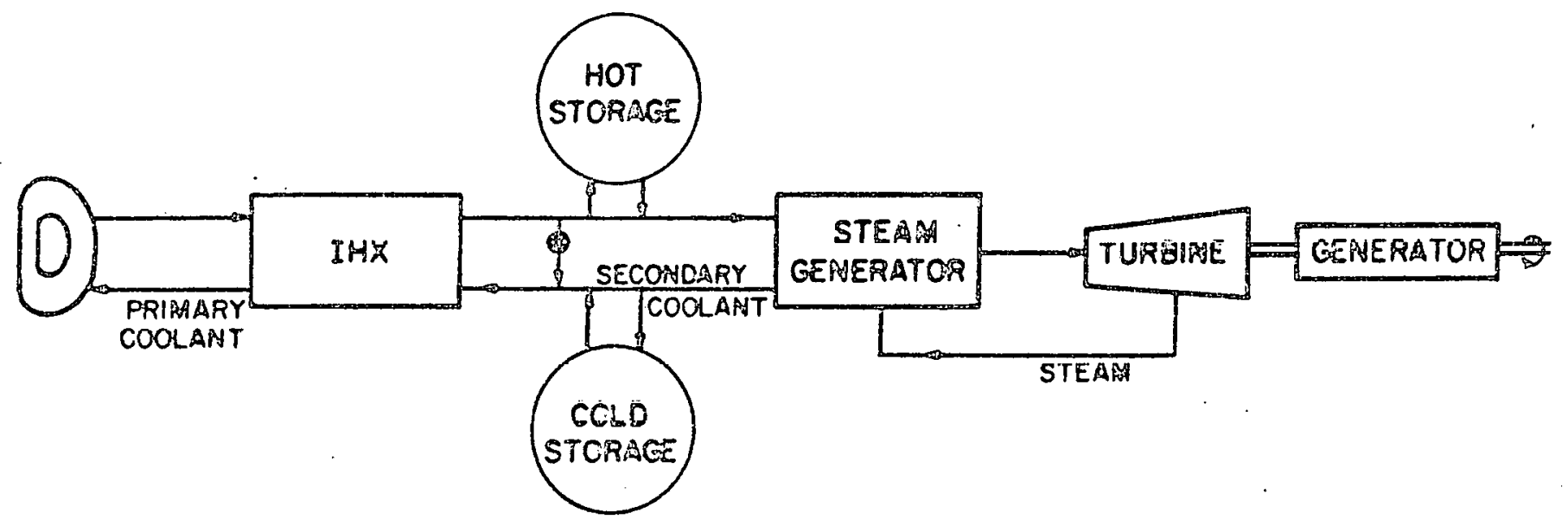

POWER CYCLE FOR A CONVENTIONAL TOKABAK

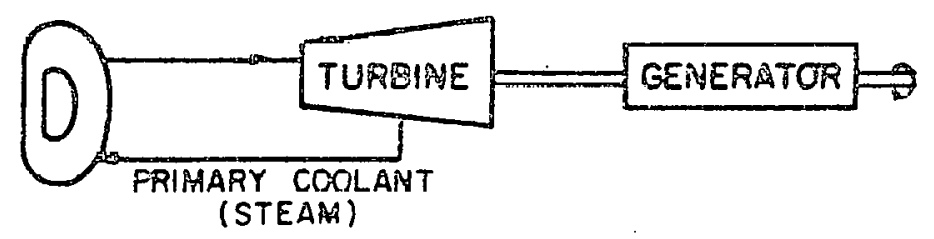

PONER CYCLE FOR NUWAAAK (BWR TECHNOLOGY)

Figure 7-1: Comparison of Power Cycle of NUWMAK to a Conventlonal TOKAMAR Reactor 


\subsection{GENERAL PLANT CONFIGURATION}

An overall plant layout for two 660 MWe NUWMAK reactors is shown in Figure 7-2 with one reactor building layout shown in Figure 7-3. The functions of each building are briefly described below:

- A Reactor Building houses the reactor and other components of the nuclear island, providing primary containment.

- Two auxiliary buildings contain equipment to handle radioactive. materlal, the tritium handling system, and other auxiliary equipment needed near the Reactor Building.

- A Hot Cell receives and processes irradiated blanket and other reactor components, providing temporary storage for these materiais.

2 A Radwaste Building processes all of the radioactive waste from the tritium handling and coolant purification systems.

- A Turbine Building contains the turbines and associated equipment (steam drums, condensers, etc.).

- A Maintenance Building contains the equipment needed to maintain the radioactive components of the reactor.

- An Administration and Control Building is located separate from the Reactor Building complex.

- Energy Storage, Invertor, and Miscellaneous Buildings house the remaining equipment and facilities.

The fusion plant generates electricity using deuterium obtained from heavy water and tritium, which (after initial fueling) is generated from lithium conversion in the reactor blanket. The blanket design is unique, using a breeding material which will operate at its melting point, thereby storing energy. The reactor is a Tokamak operating cyclically at a duty factor of 0.91 with energy stored in the blanket. Boiling water is used to transfer the energy from the reactor blanket to the turbines, eliminating the need for two coolant loops (as in the UWMAK designs). Existing Boiling Water Reactor (BWR) technology can be used for the power cycle. 


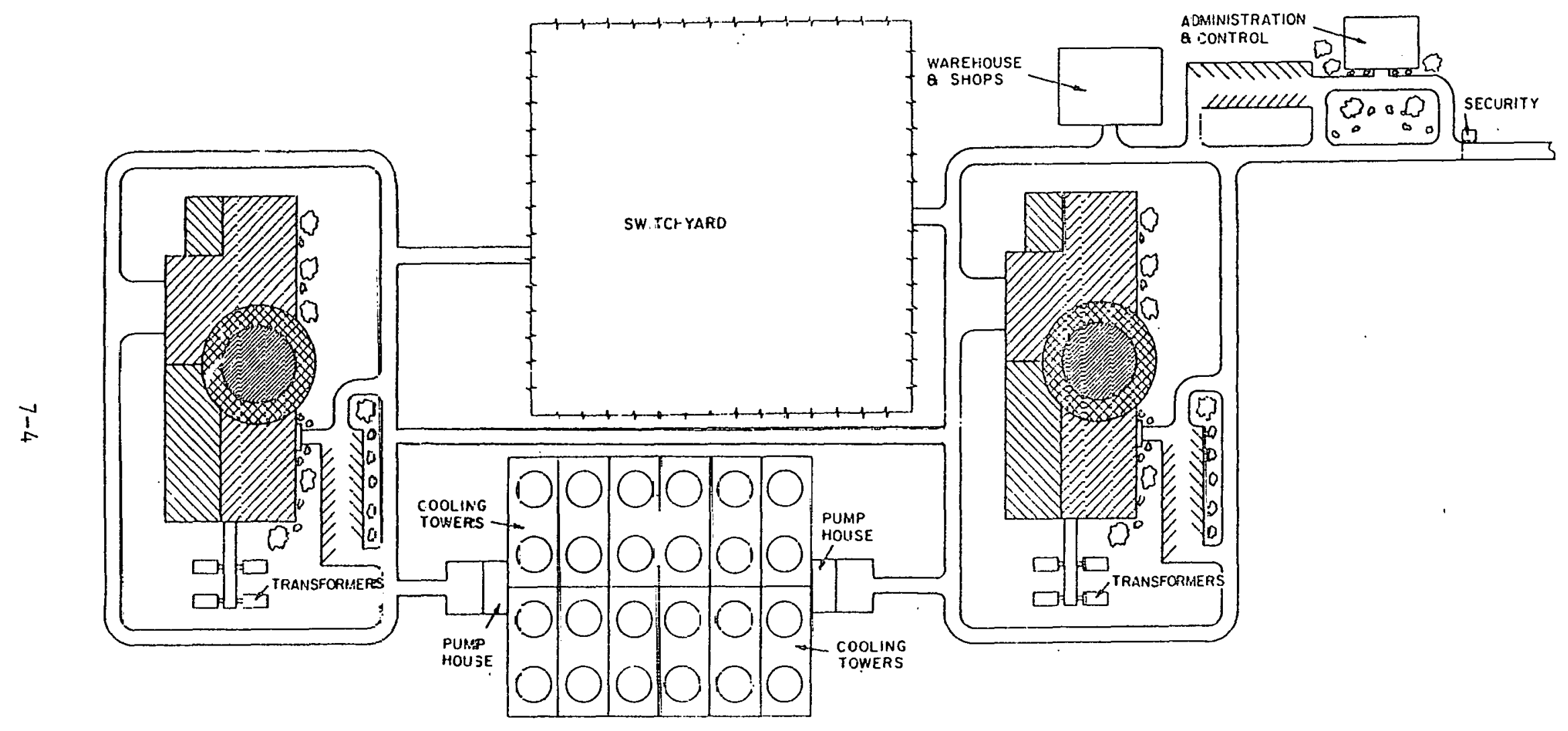

Figuxe 7-2. Overa11 21.ant Layout for Two 660 MWe NLWMAK 


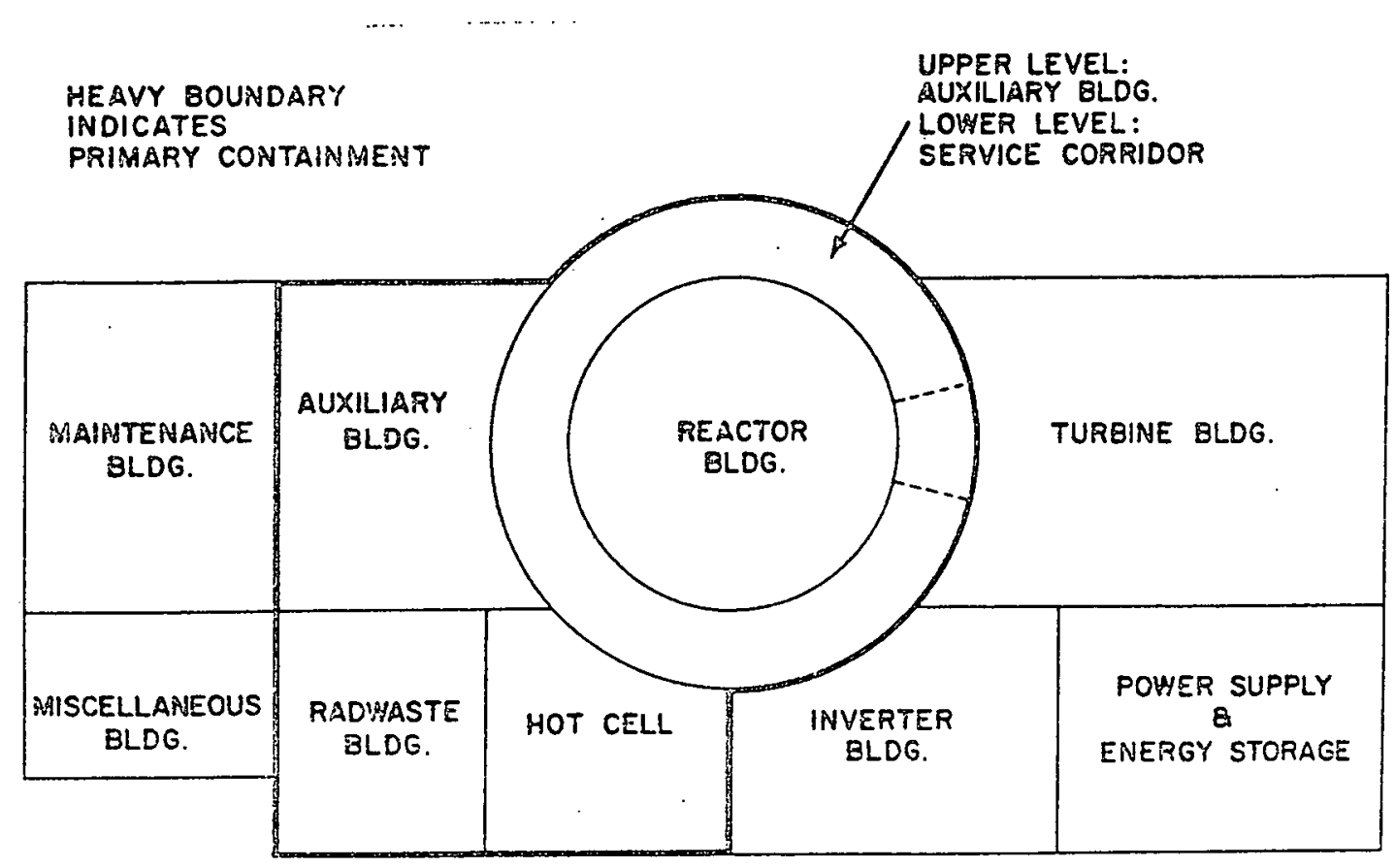

Figure 7-3. NUWMAK Reactor Building Layout

Apart from the normal cooling tower discharges, there are two environmental residuals that need to be controlled. The first is tritium. Tritium is a primary fuel and is radioactive (beta emitter). The Reactor Building is hermetically sealed so that at ambient air temperatures the tritium diffusion rate is relatively slow enabling tritium scavenging systems to keep radioactive fluid emission to less than 1 curie/day. The other source of radioactivity is from replacement of blanket modules which have become radioactive through neutron activation. The use of titanium alloys for structural material significantly reduces the problem since these materials should have longer lives under neutron bombardment than stainless steel and have less residual radioactivity (except after very long times). First wall life is estimated as 10 years. 


\subsection{THERMODYNAMIC CYCLE CHARACTERISTICS}

The reference fusion plant uses deuterium-tritium fuel. During the reactor burn cycle the deuterium (D) and tritium ( $T$ ) exist in the torroidal reactor chambers in a plasma state. When a D-T fusion reaction occurs, a helium 4 nucleus (alpha particle) is formed and a neutron is given off. This reaction and energy balance is shown in Figure 7-4.

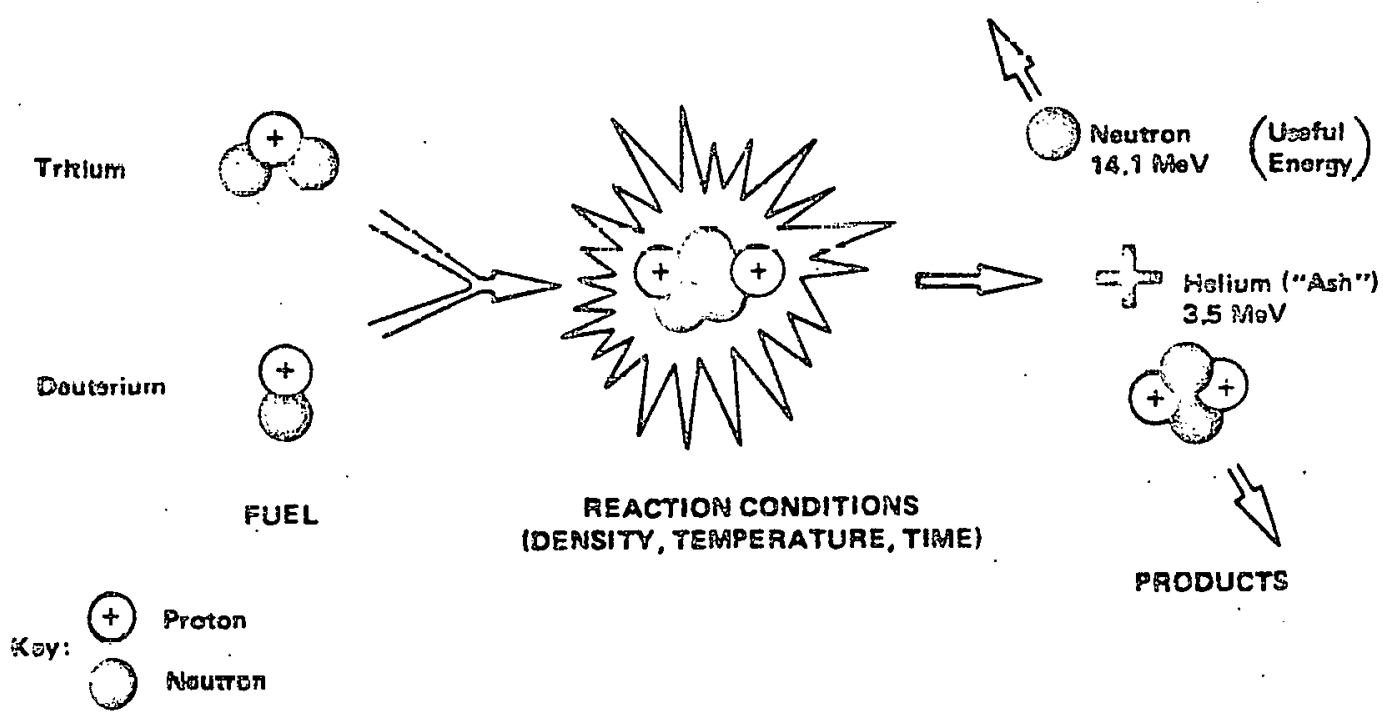

Flgure 7-4, Dentertim-Tritiun (D-T) Fucion Reaction.

The high-energy neutrons produced are absorbed by a blanket which surrounds the fusion reaction chamber. The neutrons heat the blanket and then this heat is removed from the blanket and used to produce electricity. NUWMAK uses boiling water as a coolant and a conventional boiling water reactor (BWR) power cycle to produce electricity.

The power flow for oue NUWMAk reactor is shown in Figure 705 . The yross thermal efficiency is $34.5 \%$. After accounting for auxiliary power requirements of $65 \mathrm{MW}$ and cooling of the magnets of $60 \mathrm{MW}$, the net power output is 660 MWe with a net thermal efficiency of $31.5 \%$. Two reactors would have a net output of 1320 MWe. 


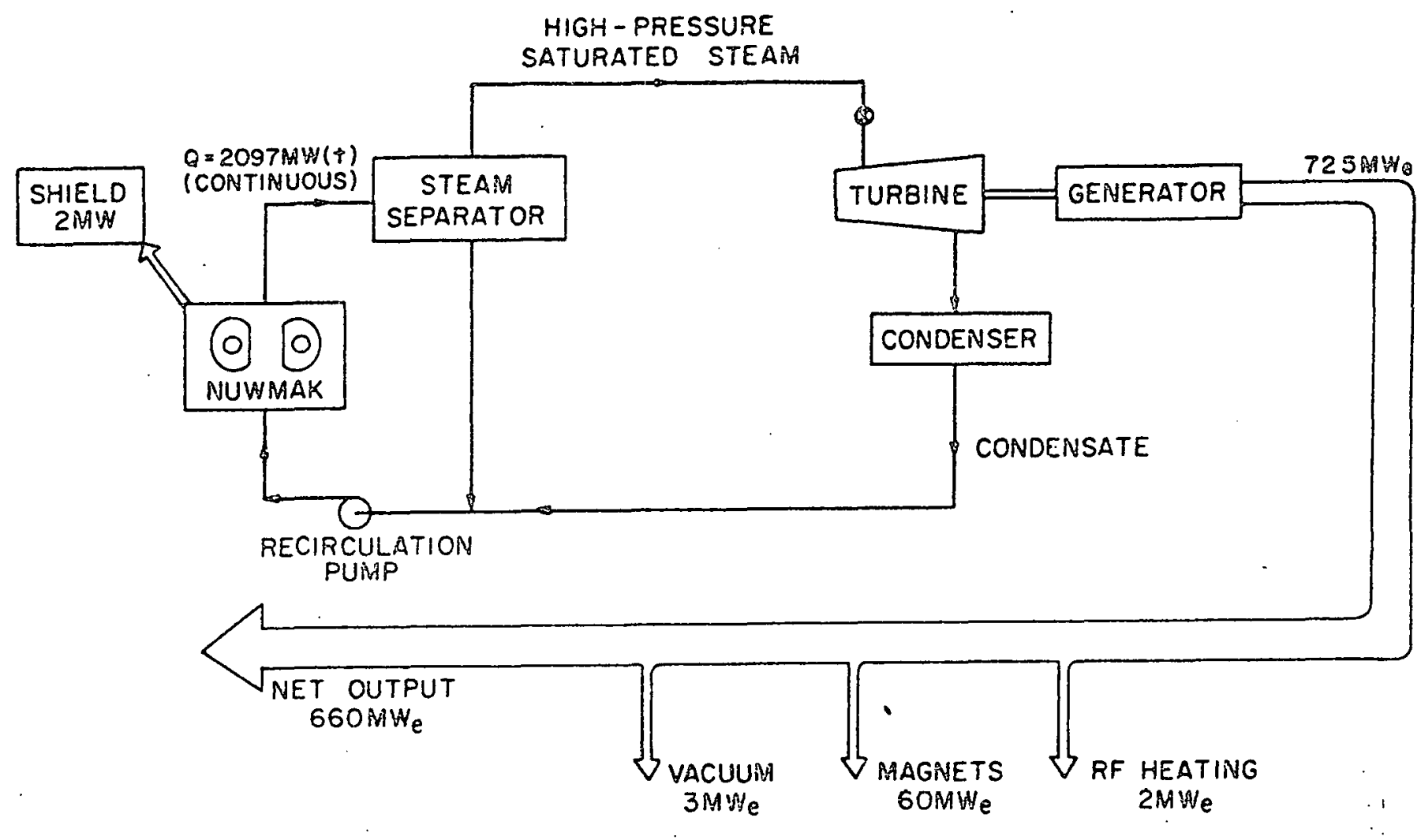

Figure 7-5. Power Flow Diagram for NUWMAK

\subsection{FUSION REACTOR}

The controlled nuclear fusion reactions which supply the heat to the blanket coolant system are not simple to produce. In fact, scientific breakeven (energy output from the reactions equal to energy input to produce the rcactions) has iul yet been achieved. Sustained fusion reactions require a plasma with very high temperature and high density, confined sufficiently long. In a NUWMAK reactor, the plasma will be initially heated by ohmic (resistance) heating and with radio frequency ( $R F$ ) waves and contained by strong magnetic fields. The reactor is a Tokamak type, in which the plasma is contained in a toroid. A cross section of one reactor as cut through a toroidal field (TF) coil is showil in Figure 7-6. The plasma is contained in "D" shape at a density of about $3.1 \times 10^{14}$ ions $/ \mathrm{cm}^{3}$. 


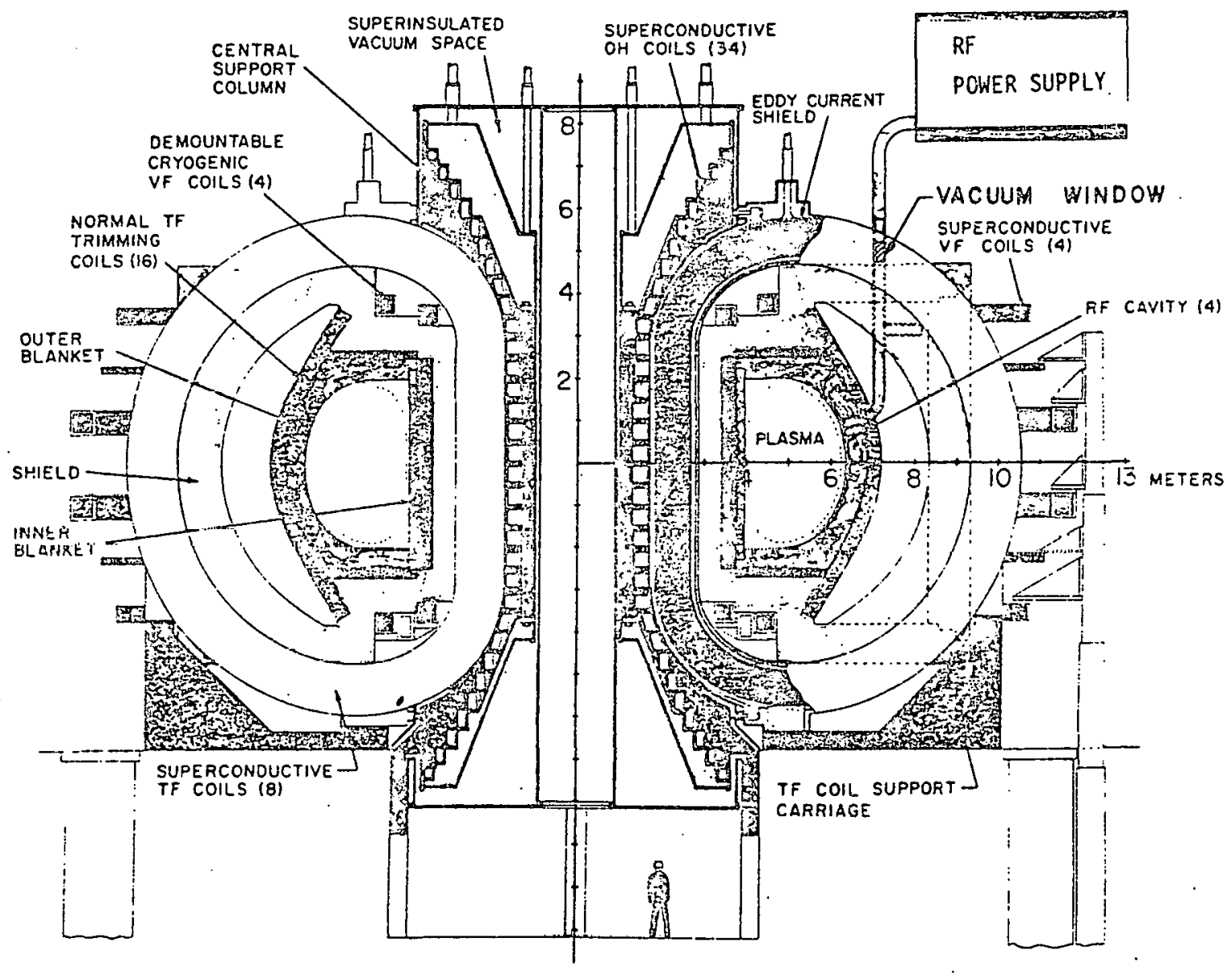

Figure 7-6. Cross-Sectional View of NUWMAK

The NUWMAK reactors differ from those of previous studies (such as UWMAK) in that no divertor is used. Impurity control (which is needed in order to keep the plasma trom cooling) is accomplished inscead by. gas puffling. The gas puffing, along with partial pellet fueling, permit operation for approx1mately 225 seconds with adequate plasma cleanliness. During a burn, neutral deuterium gas is puffed into the plasma periodically with a time between puffs of about 0.5 seconds. Tritium is introduced in solid pellets, which penetrate only the outer plasma mantel. A sharp temperature profile develops at the plasma edge which is maintained cold by both the gas puffing and by impurity introduction. However, the step temperature profile prevents impurities from diffusing towards the plasma center. The impurities are neutralized and pumped out through vacuum pump ports. 
The plasma requires a magnetic field of 6.05 tesla at a major radius of 5.13 meters, which means a maximum field of 12 tesla at the magnet. To provide the needed access for maintenance and repair, NUWMAK is designed with only eight large superconducting " $D$ "-shaped TF coils and the increased ripple is corrected with 16 saddle-shaped trimming coils. The primary design of the TF coil uses NbTi superconductor with subcooled superfluid liquid helium at $1.8^{\circ} \mathrm{K}$ and atmospheric pressure. There are four cryogenic vertical field coils inside of the TF coils and four superconducting coils at the outside of the TF coils to maintain the elongated plasma. The ohmic heating coils are 1ocated inside the central core of the reactor system. Since the magnets require a pulsed power supply, each reactor is supplied with a two MWh superconductive energy storage unit.

Since ohmic heating is effective only at relatively low plasma temperatures, auxiliary heating is necessary to raise plasma temperatures to ignition conditions (when fusion reactions will sustain themselves without further heat input). The NUWMAK design employs radio-frequency (RF) supplementary heating in the ion cyclotron range of frequencies in order to startup the plasma. It is proposed to launch a fast magnetosonic wave into a 50-50 DT plasma and heat the ions at the second harmonic cyclotron frequency of deuterium. Most of the present-day magnetic fusion reactor designs advocate the use of neutral beams for heating and fueling purposes. However, the potential advantages of RF heating (such as lower technological demands) led to its choice for NUWMAK. For a power absorption of $80 \mathrm{MW}$ by the plasma in one reactor, a prime power of $136 \mathrm{MW}$ is required from the line or $272 \mathrm{MW}$ total. This number may be optimistic.

\subsection{THE REACTOR BLANKET SYSTEM}

The NUWMAK blanket system is designed to alleviate or avoid problems which were uncovered in the UWMAK designs. Table 7-1 lists the major problems and solutions. 
Table 7-1.: Problems, Causes, and Possible

Solutions for a Tokamak Blanket

\begin{tabular}{|c|c|c|}
\hline Problems & Caused By & NUWMAK Solution \\
\hline Thermal Fatigue & Cyclic Plasma & $\begin{array}{l}\text { Ti Structure, Boiling Water } \\
\text { Cooling }\end{array}$ \\
\hline Thermal Storage & Cyclic Plasma & $\begin{array}{l}\text { Phase Change (of Breeding } \\
\text { Material) Thermal Storage }\end{array}$ \\
\hline Intermediate Loop & $\begin{array}{l}\mathrm{H}_{2} \mathrm{O}-\mathrm{Ii} \text { Compound Reaction } \\
\text { Possibility }\end{array}$ & $\begin{array}{l}\text { T.i62 Phj8 Breeding, Redund- } \\
\text { ant Structure }\end{array}$ \\
\hline T-Diffusion & Toward Cooling Water & $\begin{array}{l}\text { Multiple Layer Coolant Tube } \\
\text { Design }\end{array}$ \\
\hline $\begin{array}{l}\text { High 1st Wall Thermal } \\
\text { Load }\end{array}$ & $\begin{array}{l}\text { High Wall Loading, No } \\
\text { Divertor }\end{array}$ & $\begin{array}{l}\text { Ti Structure, Boiling Water } \\
\text { Cooling }\end{array}$ \\
\hline Coolant Tube Maintenance & Tubè Leak & $\begin{array}{l}\text { Double Wall Tubes } \\
\text { (Redundancy) }\end{array}$ \\
\hline $\begin{array}{l}\text { Waste Disposal, } \\
\text { Reprocessing }\end{array}$ & Radioactivity & Ti structure \\
\hline Blanket Life & Radiation Damage & Low Operating Temperature \\
\hline
\end{tabular}

A cross-sectional view of the NUWMAK blanket is shown in Figure 7-7. The blanket structure is a titanium alloy, Ti-6Al-4V, designed with a maximum temperature of $400^{\circ} \mathrm{C}$ at the coolant tube wall for phase stability. The maximum design temperature in the blanket is $500^{\circ} \mathrm{C}$. The coolant is boiling water at $300^{\circ} \mathrm{C}$ with a pressure of $8.6 \mathrm{MPa}$ (1250 psi). The design life for the blanket module is two years.

The blanket resembles a large phase change energy storage tank. The first wall is formed by a continuous bank of tubes, with the space between the tubes filled with Li-62 $\mathrm{Pb}-38$, the breeding and energy storage material. This breeding material is solid around the coolant tube and liquid in between the tubes, with energy storage provided by the movement of the solid-liquid interface (melting temperature is $464^{\circ} \mathrm{C}$ ). 


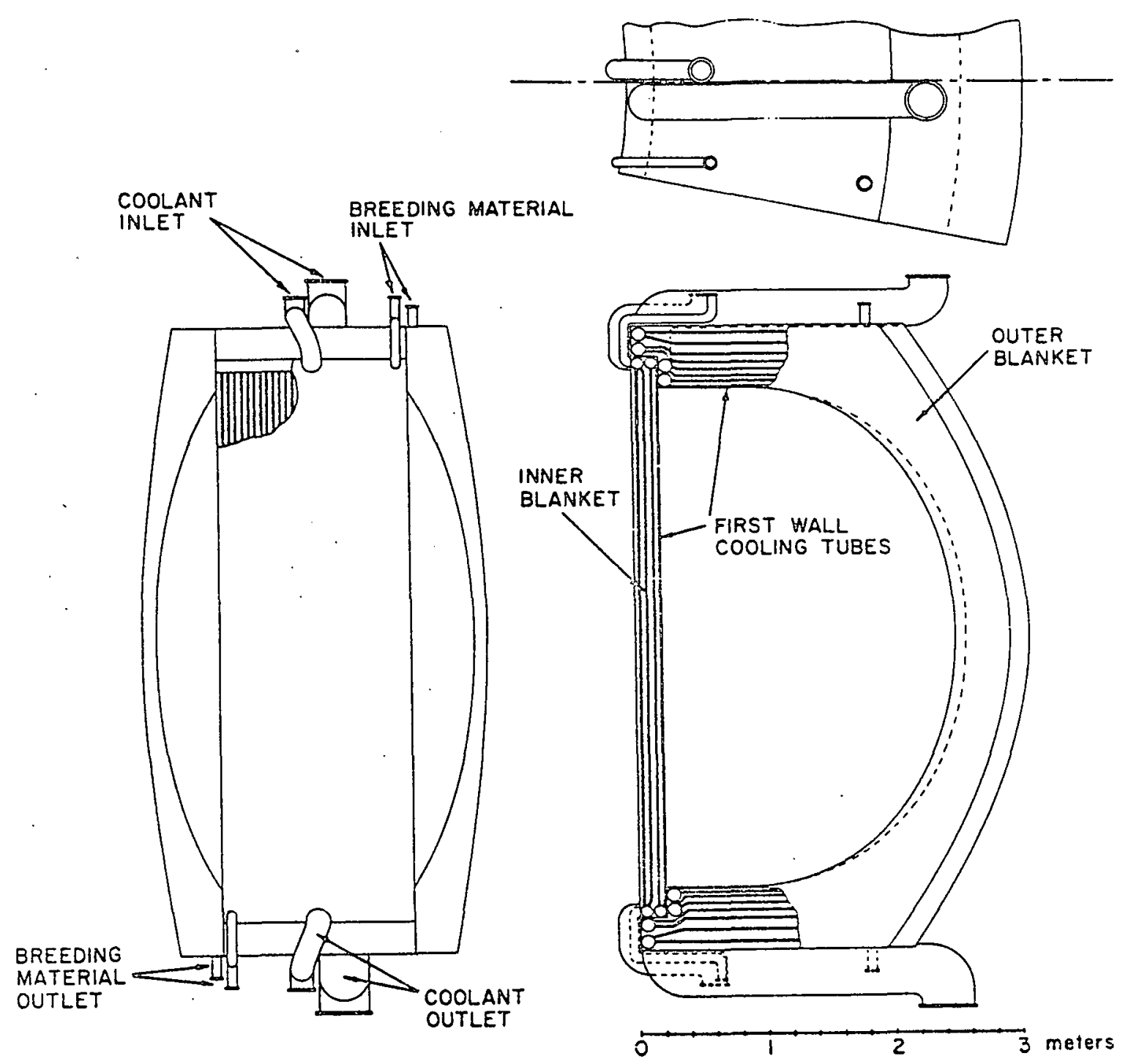

Figure 7-7. Cross-Sertinnal. View of Blanket

\subsection{THERMODYNAMIC PARAMETERS}

The NUWMAK reactor operates with a cycle length of 245 seconds: 225 seconds of burn followed by 20 seconds of down time. The heat stored in the blanket material provides energy to the coolant during the down time, reducing the cyclic varialiun frum $70 \%$ to $30 \%$ of the maximum energy to the turbines. As a $30 \%$ variation is still unacceptable, a steam drum is used and the feed water temperature is adjusted. Figure 7-8 is a schematic of this loadleveling system. Constant electrical output can be achieved with this system. Simultaneous operation of the two reactors is not necescary for conatant electrical output. 
To H.P. turbine

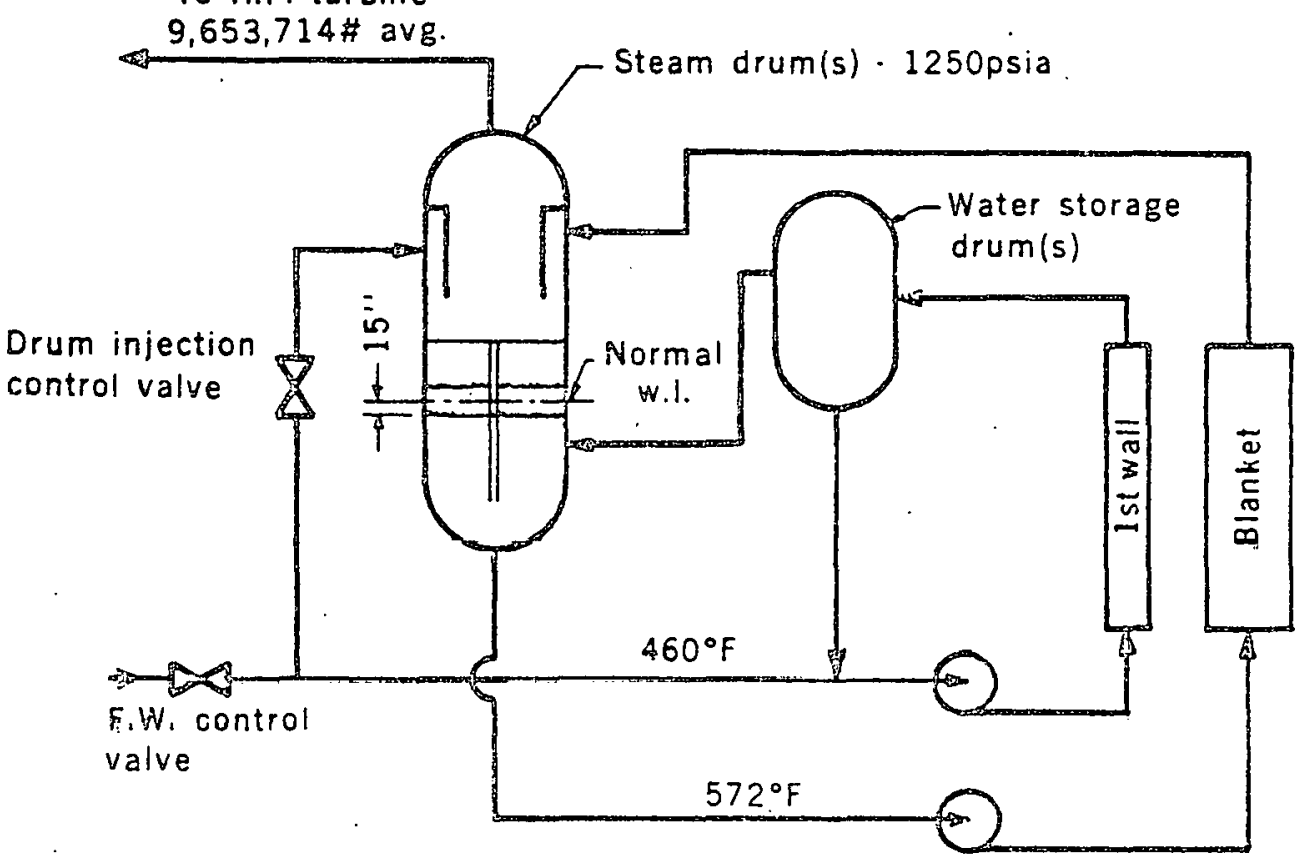

Figure 7-8. Schematic Showing Components in NUWMAK Load-Leveling System

The thermodynamic parameters for one NUWMAK reactor are given in Table 7-2. Two reactors would produce $4566 \mathrm{MW}$ of gross power during burn with a net electrical output of 1320 MWe. Since the burn time is $92 \%$ of the cycle time, the net thermal efficiency is $31.5 \%$. 
Table 7-2. Summary of Thermodynamic Parameters for One NUWMAK Reactor

\begin{tabular}{|c|c|}
\hline Parameter & Value \\
\hline Power Output (During Burn) & $2283 \mathrm{MW}$ \\
\hline Blanket Energy (Continuous) & $1900 \mathrm{MW}$ \\
\hline Neutron Wall Loading & $4.34 \mathrm{MN} / \mathrm{m}^{2}$ \\
\hline First Wall Area & $360 \mathrm{~m}^{2}$ \\
\hline Total Thermal Wall Loading & $6.34 \mathrm{MW} / \mathrm{m}^{2}$ \\
\hline First Wall Thermal Loading & $1.08 \mathrm{MW} / \mathrm{m}^{2}$ \\
\hline Plasma Burn Time & 225 Second \\
\hline Plasma Down Time & 20 Second \\
\hline Structure & Ti Alloy \\
\hline Breeding Material & $\mathrm{Li}_{62} \mathrm{~Pb}_{38}$ Eutectic \\
\hline Energy Storage Material & $\mathrm{Li}_{62} \mathrm{Po}_{38}$ Eutectic \\
\hline Coolant & Boiling $\mathrm{H}_{2} \mathrm{O}^{\circ}$ \\
\hline Coolant Temperature & $300^{\circ} \mathrm{C}$ \\
\hline Coolant Pressure & $8.6 \mathrm{MPa}$ \\
\hline Maximum Coolant Wall Temperature & $400^{\circ} \mathrm{C}$ \\
\hline Maximum Coolant Wall Stress & $100 \mathrm{MPa}$ \\
\hline Maximum Blanket Temperature & $500^{\circ} \mathrm{C}$ \\
\hline Average Coolant Tube Thermal Load & $44 \mathrm{~W} / \mathrm{cm}^{2}$ \\
\hline Total Coolant Tube Surface Area & $4350 m^{2}$ \\
\hline Net Power Output (Continuous) & $660 \mathrm{MWe}$ \\
\hline Net Thermal Efficiency & $31.5 \%$ \\
\hline
\end{tabular}




\subsection{FUEI USE}

In a "worst case" fueling scheme with deuterium-tritium (DT) gas puffing and "shallow" DT pellet injection, $13.82 \times 10^{20}$ tritium atoms/sec. are burned in the two reactors to produce $4566 \mathrm{MWt}$. Tritium is injected as a DT gas blanket at a rate of $4.06 \times 10^{22} \mathrm{~T}$ atoms/sec and as DT pellets at a rate of $18.06 \times 10^{22} \mathrm{~T}$ atoms/sec. This results in a burn fraction of only $0.62 \%$. Tritium in storage for one day's supply at a burn cycle duty factor of $91.8 \%$ is $88 \mathrm{~kg}$. The tritium inventory under this scheme is given in Table 7-3.

Table 7-3. Tritium Inventory Under a DT Pellet Fueling Scheme

\begin{tabular}{|c|c|}
\hline Components & $\begin{array}{c}\text { Ainumit uf } \\
\text { Tritium }\end{array}$ \\
\hline Fueling System & $84.0 \mathrm{~kg}$ \\
Cryopumps (4 hr. cycle time) & $88.0 \mathrm{~kg}$ \\
Storage (1 day's supply, 91.8\% duty factor) & $1.6 \mathrm{~kg}$ \\
Purification System & $0.18 \mathrm{~kg}$ \\
Distillation Columns & $173.8 \mathrm{~kg}$ \\
Blanket (no change over original case) & \\
Total &
\end{tabular}

The detailed calculations for "deep pellet" fueling have not yet been worked out. However, it has been found that injection of tritium deep into the center of a plasma surrounded by a cold gas blanket of $\mathrm{D}_{2}$ should increase the particle confinement time at the plasma's center by a factor of ten compared to the "shallow pellet" fueling technique. Thus, the anticipated burn fraction would be about $6 \%$. This represents a best case fueling scheme and would have associated with it inventories and handling capacities reduced by a factor of about ten.

The tritium, after initial fueling, is recovered from the blanket breeding material. A breeding ratio of 1.54 is planned to ensure a continuing supply of tritium. Residual tritium and deuterium are also recovered from the plasma and recycied. 


\subsection{ENVIRONMENTAL CHARACTERISTICS}

There are four direct enviromental effects caused by fusion power plants:

- Water/air emissions of radioactive tritium

- Radioactive solid waste (blanket and structural components)

- Use of water resources

- Use of land resource

\subsection{TRITIUM}

The total tritium inventory in NUWMAK may amount to more than $10^{10} \mathrm{Ci}$. In order to limit tritium releases from NUWMAK to less than $10 \mathrm{Ci}$ per day, tritium losses must be limited to one part in one hundred million on a daily basis. Such a monumental task must rely on the most conservative containment measures possible. Essentially perfect containment of tritium depends on clearly identifying possible routes of tritium release. During normal operation, plasma fueling and fuel purification components, storage (both normal and emergency), breeding and tritium extraction system components, and the first waIl and blanket coolant are all sources of potential tritium losses. Tritium containment associated with each of these systems is examined in the analysis of a multi-layer containment system.

The three-level containment system (Figure 7-9) is designed to deal with tritium release under both normal and off-normal conditions. Each level prevents the dilution of released tritium so that it can be recovered before permeating to the next barrier.

The primary containment system consists of those pipes and other structural elements which contain tritium or tritium-bearing materials. These components must demonstrate high structural integrity for the containment of tritium. Connections must be welded and leak tested extensively with helium prior to the introduction of tritium. Division of the fueling and fuel storage system into eight identical units reduces the size of the maximum tritium release possible.

The secondary containment system consists mainly of a second physical barrier around primary system components. Thus, primary system piping outside the plasma chamber is contained within larger diameter piping. A slowly 


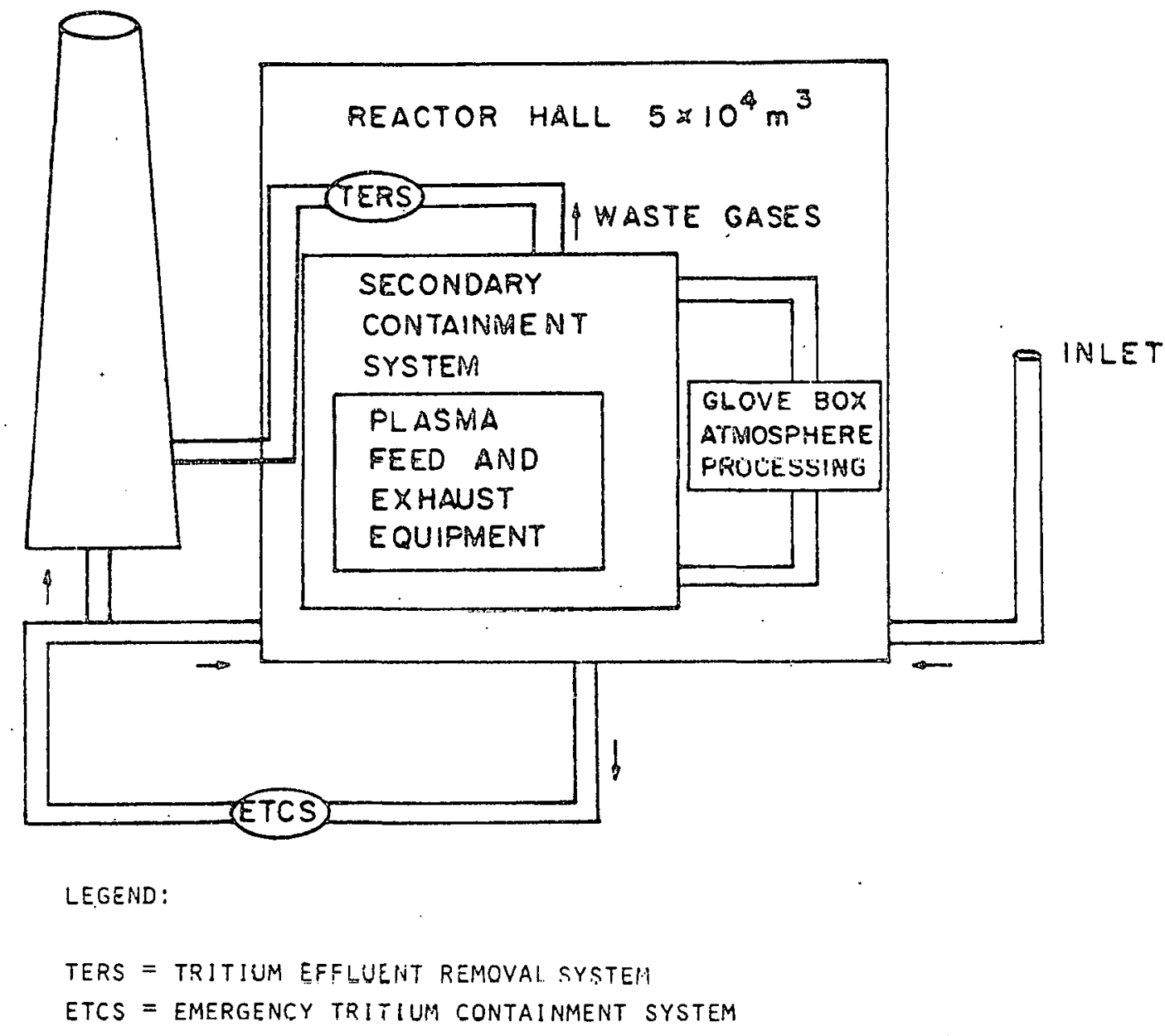

Figure 7-9. Tritium Effluent System Design

flowing inert gas is passed through the annulus and monitored for tritium leakage. Large pieces of equipment requiring maintenance or adjustment are enclosed in glove boxes. Estimates currently hold that approximately $1 \%$ of the building volume will contain high enough levels of radioactivity to require enclosure within glove boxes. These glove boxes will contain a circulating inert gas which is monitored for tritium.

If the level of tritium goes above 2ppm, the glove box atmosphere can be diverted to a tritium removal system (TERS) or an emergency detritiation system (ETCS) as needed. Especially leaky components of the primary system can be enclosed in special glove boxes equipped with cryogenic absorption or hydrogen getters to control tritium losses when needed. 
The tertiary containment system includes the reactor hall, rooms containing tritium processing equipment, the reactor building itself, the tritium effluent removal system (TERS), and the emergency tritium containment system (ETCS). The TERS is designed to operate on routine tritium losses while the ETCS is only used under off-normal conditions.

As with the primary and secondary systems, the reactor building is subdivided to reduce both the extent of loss and the extent of contanination in the event of a leak. Each reactor hall has a volume of $8.7 \times 10^{4} \mathrm{~m}^{3}$ and may be divided radially to provide the least impediment to maintenance operations. The reactor building is maintained at 70 torr during operation, with the capability of attaining 10 torr under emergency conditions.

About $20 \%$ of the building volume atmosphere per day should be circulated through the building from areas of smallest to largest radioactive hazard before leaving through a stack of sufficient height to guranatee proper dispersal of the effluent. Under normal operation, this stack effluent would contain about $1 \mathrm{Ci}$ per day. The main reactor hall should not be ventilated routinely due to the existence of the short-iived, but hazardous isotopes ${ }^{13} \mathrm{~N},{ }^{16} \mathrm{~N}$, and ${ }^{41}{ }_{\mathrm{Ar}}$ created by neutron leakage from the reactor.

Routine processing of exhaust gases from vacuum pumps and purge gases is performed by the TERS. The TERS converts gaseous waste (HT, tritiated hydrocarbons, etc.) to tritiated water which is collected. This water and other liquid and solid tritiated waste is then fixed for burial in a solid matrix such as concrete.

The ewergency LiLlium cunlalnuent system (ETCS) consists of a heated catalyst to oxidize $\mathrm{HT}$ and $\mathrm{T}_{2}$ to $\mathrm{HTO}$ and $\mathrm{T}_{2} \mathrm{O}$, alumina beds presaturated with water at $100 \%$ humidity, and the required air handling equipment. The ETCS is used in the event of a simultaneous breakdown of both the primary and secondary systems to rapidly detritiate air from contaminated areas of the reactor building. During cleanup, the inlet dampers of contaminated areas are closed and only a small fraction of fresh air is allowed to circulate to reduce tritium losses from the stack.

One further source of tritium leakage is the boiling water coolant. It has been calculated that the leak rate of tritium into the cooling water will be limlted to a few curles per day. In the event that the leak rate increases, 
it is possible, at comparable costs, to remove tritium (in the range of 0.001 to $10 \mu \mathrm{Ci} / \mathrm{ml}$ ), either by combined electrolysis-catalysis or by molecular photo-excitation.

\subsection{BLANKET (SOLID RADIOACTIVE) WASTE}

The $14 \mathrm{MeV}$ neutrons from the fusion reaction induce radioactivity in the structure surrounding the plasma. Figure 7-10 shows the radioactivity of the reactor in curies per watt thermal. For comparison purposes, the activity of UWMAK-I is also shown. Most of the activity originates in the inner region of the blanket. In comparing the activity of the titanium alloy in NUWMAK with the stainless steel UWMAK-I design, it is seen that some improvement has been made especially in the one year to 1000 year time span. Initially the activity per watt is only lower by a factor of about two. The afterheat results (Figure 7-1I) and Biological Hazard Potential (BHP) results (Figure 7-12) show qualitatively similar behavior with the primary difference being the very long term behavior of the BHP for NUWMAR.

The radioactivity, afterheat, and BHP after one year of continuous operation are 0.8 curie/Wt, $0.5 \%$ of operating power, and $2 \times 10^{2} \mathrm{~km}^{3}$ air $/ \mathrm{kWt}$, respectively. However, they drop by between 4 to 5 orders of magnitude 10 years after shutdown.

The blanket is expected to be replaced every two years with the material processed and stored on the plant site.

\subsection{LAND AND WATER USE}

The two-unit reference fusion plant is expected to require a 500 acre site including the mainplants, switchyard, cooling towers, access roads and buffer zones. Temporary on-șite sțorage of structural radinartive waste requires a negligible area. The radioactive material storage requirement in volumetric terms is about $8.5 \mathrm{~m}^{3} / \mathrm{yr}$ for each of the two units.

The primary water use is for cooling and cooling tower blowdown and is expected to be comparable to that of an equivalent capacity BIR. 


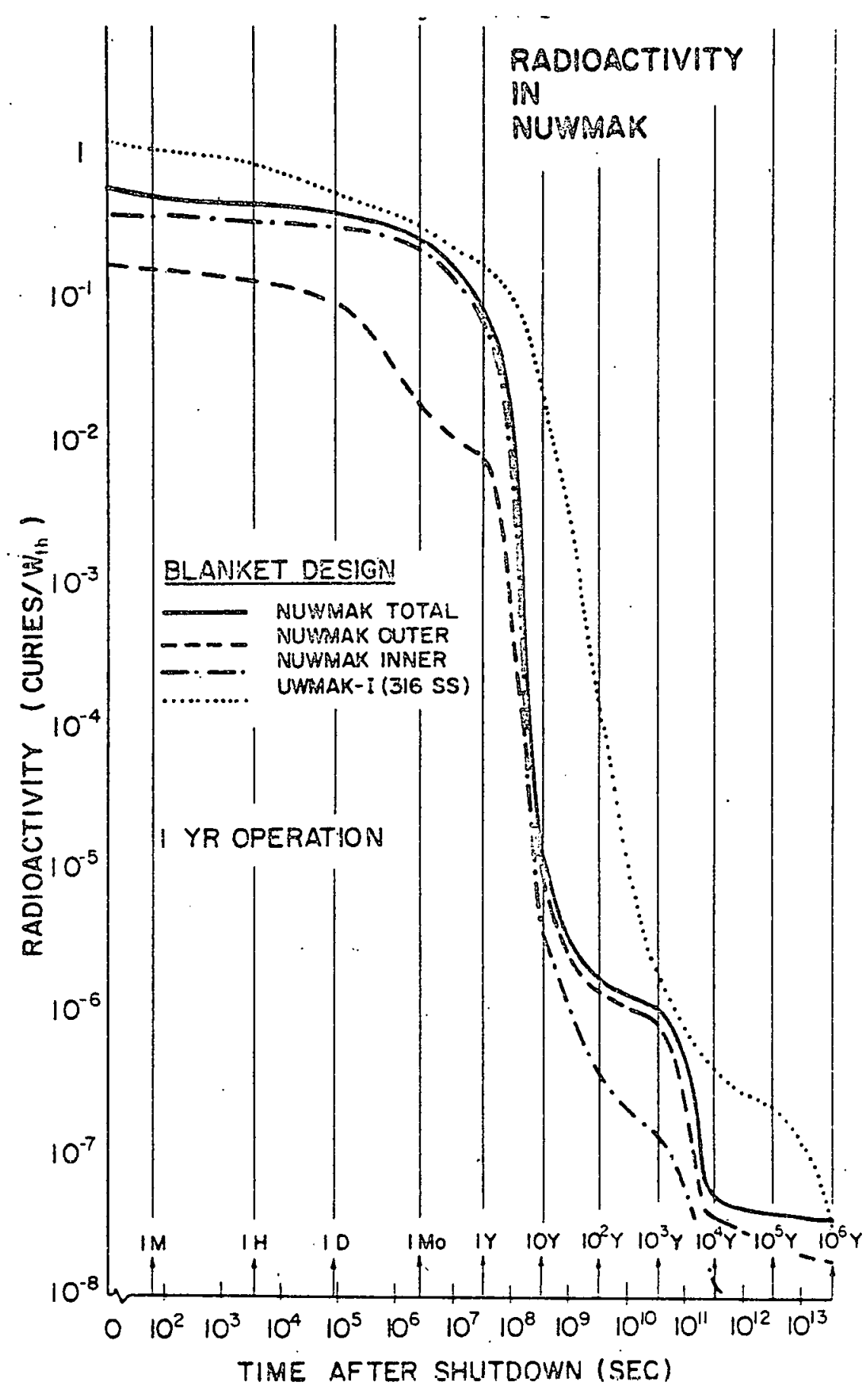

Figure 7-10. Radioactivity of the NUWMAK 


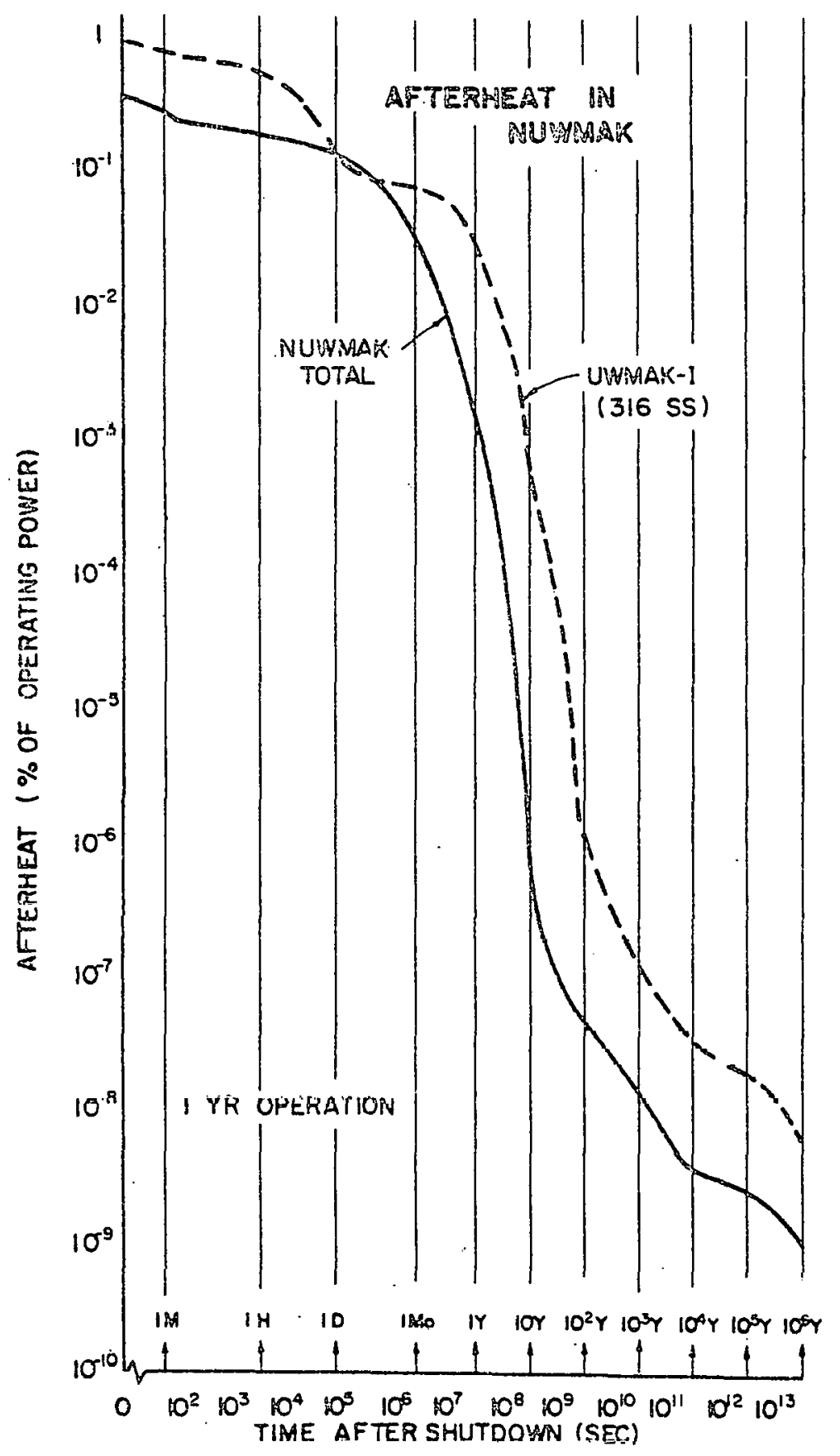

Figure 7-11. Afterheat in NUWMAK 


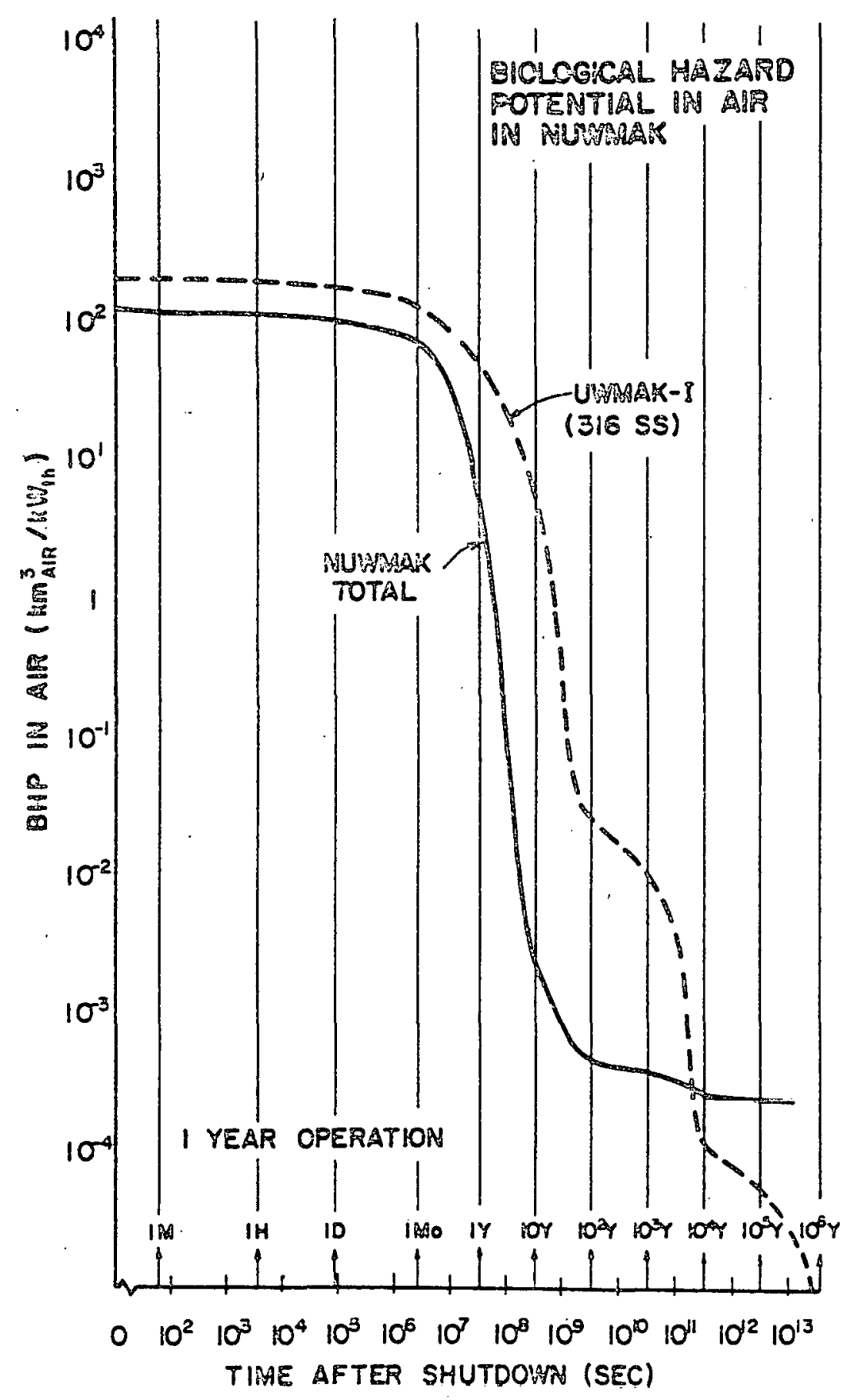

Figure 7-12. Biological Hazard Potential for NUWMAK 


\subsection{CONSTRUCTION AND OPERATING CHARACTERISTICS}

\subsection{CONSTRUCTION TIME}

The NUWMAK study assumed an eight-year construction period for a single 660 MNe plant. This estimate is two years less than that for earlier UWMAK designs on the grounds that NUWMAK is a sma.ller and less complicated reactor which utilizes current BWR technology in the power cycle. For the two-unit reference plant characterized herein, a ten year total construction time is assumed with the first unit being completed after eight years and the second unit two years later.

\subsection{CONSTRUCTION PERSONNET, RFOIIIREMENTS}

A total direct craft labor requirement of $2.13 \times 10^{7}$ man-hours is estimated for construction of the referenre two-unit plant. About 10 percent. of this labor requirement is for construction of the reactor plants themselves, which is about the same as that required for construction of the reactor portion of a 1190 MWe BWR. A construction personnel requirements breakdown by craft type is not available.

\section{ל.3 RESOURCE REQUIREMENTS}

The total materials requirements for a 300 GWe installed caparity of NUWIAK-cype reactors are shown in Table 7-4. While this leve 1 nf fusion development would not place a severe burden on resources available from the domestic market at projected or possible future prices, three materials, $\mathrm{Nb}$, $W$, and $\mathrm{Co}$, would be required from foreign sources. The supply and demand for Lhese materials would require careful monitoring as fusion power develops. 
Table 7-4. Materials Requirements and Availability in a 300 GWe Economy of NUWMAK Type Reactors

\begin{tabular}{|c|c|}
\hline Group \& Metal & $\begin{array}{l}\text { Total Requirement } \\
\text { (in metric tonnes } \times 10^{3} \text { ) }\end{array}$ \\
\hline \multicolumn{2}{|l|}{$\begin{array}{c}\text { Group A - Materials available from } \\
\text { domestic mines at market prices }\end{array}$} \\
\hline Boron & 670 \\
\hline Carbon & 328 \\
\hline Copper & 355 \\
\hline - Iron & 16,909 \\
\hline Lead & 849 \\
\hline Lithium & 19 \\
\hline Magnesium & 2 \\
\hline Zirconium & 0.5 \\
\hline Molybdenum & 20 \\
\hline \multicolumn{2}{|l|}{$\begin{array}{l}\text { Group B - Materials available from } \\
\text { domestic mines at } 3 x \text { market prices }\end{array}$} \\
\hline Aluminum & 672 \\
\hline Chromium & 104 \\
\hline Titanium & 386 \\
\hline Manganese & 16 \\
\hline Vanadium & 35 \\
\hline Nicke1 & 13 \\
\hline \multicolumn{2}{|l|}{$\begin{array}{l}\text { Group C - Materials available in } \\
\text { adequate amounts only from foreign } \\
\text { sources }\end{array}$} \\
\hline Niobium & 23 \\
\hline Tungsten & 312 \\
\hline Cobalt & 20 \\
\hline
\end{tabular}




\subsection{OPERATING PERSONNEL REQUIREMENTS}

Total staffing requirements for the reference fusion plant are estimated to be 300 persons including security and peak maintenance personnel. This estimate is based on staffing requirements for LWR plants having two 400-700 MWe units per site. A breakdown of the operating staff is shown below.

\section{Estimated Staff Requirements for Reference Fusion Plant*}

$\begin{array}{lr}\text { Plant manager's office } & \\ \text { Nanager } & 1 \\ \text { Assistant } & 2 \\ \text { Quality assurance } & 4 \\ \text { Environmental control } & 1 \\ \text { Public rclationo } & 1 \\ \text { Training } & 1 \\ \text { Safety } & 1 \\ \text { Administrative services } & 15 \\ \text { Health services } & 1 \\ \text { Security } & \underline{56} \\ \quad \text { Subtotal } & 83\end{array}$

Operations

Supervision (excluding shift) 2

Shifts $\quad \underline{48}$

Sub to tal 50

Maintenance

Supervision $\quad 8$

Crafts 22

Peak maintenance annualized $\quad \underline{110}$

Sub total 140

Technical and engineering

Reactor

Radiochemical

Instrumentation and controls 2

Performance, reports, and technicians

Subtotal 27

TOTAI STAFF 300

Less security $\quad .244$

Less security and peak maintenance $\quad 134$

*Source: "A Procedure for Estimating Nonfuel Operation and Maintenance Costs for Large Steam-Electric Power Plants," ORNL/TM-6467, January 1979. 


\subsection{PLANT AVAILABILITY}

Unit availability in the NUWMAK study is estimated to be 80.8 percent. This estimate is based on four weeks (672 hours) of unscheduled downtime per year and six weeks (1008 hours) of scheduled downtime per year. It was assumed that all the first wall/blanket material and the limiters will be replaced every two years, with one-half of the first wall/blanket/limiter material replaced each year on a regular schedule. The six week scheduled. downtime period must thus be adequate for replacement of eight of the sixteen first wall/blanket modules.

For the reference plant characterization it was assumed the two-unit plant would operate at an overall capacity factor of 70 percent. 


\subsection{COST CHARACTERIZATION (FUSION)}

The base capital costs estimated for the 1320 MWe reference fusion plant have been derived from cost data presented in the "NUWMAK" report and from the "Energy Economic Data Base (EEDB) Program Phase I" report. The NUWMAK report was used as the primary source of data while the EEDB was used to derive the direct labor components for each of the major accounts (except for those of the reactor plant for which the NUWMAK presents data). Direct and indirect costs are presented on a consistent January 1,1978 basis.

\subsection{DIRECT CAPITAL COSTS}

The NUWMAK design report develops a grass roots estimate for the plant's reactor plant equipment and derives the balance of plant costs from the EEDB boiling water reactor design costs. A direct craft labor requirement of $2.13 \times 10^{6}$ man-hours is estimated for construction of the reactor plant,* while all other accounts are specified by total dollar cost with no specific breakout of the labor component. Thus, for consistency with each of the other technologies characterized in this report, the labor component for each direct cost account was estimated, based on the ratio of direct labor cost to total cost for the balance of plant accounts of the EEDB boiling water reactor design. As this design served as the basis for pstimating the original MUWMAK costa, consisteucy is preserved.

The NUWMAK design report assumed an average labor cost of $\$ 12.50 /$ man-hour. This cost has been adjusted slightly to $\$ 13.04 /$ man-hour for consistency with the average labor costs used in the reference LWR and LMF'BR characterizations.

For each of the accounts, the NUWMAK study defines four romponents of cost: identified equipment costs, design allowances, contingency, and spare parts. Contingency and spare parts costs have not been included in the base direct costs for consistency with the cost estimates of the other technologies. Design allowances, as defined in the NUWMAK report, are costs estimated to account for items overiooked in the engineering design. These costs are estiwated in the NUWMAK report at $10 \%$ of each equipment account total, except

*This labor requirement is about the same as that required for the construction of the reactor portion of a 1190 MWe boiling water reactor. 
for the reactor plant equipment where $20 \%$ is used. In light of the status of development and conceptual nature of the fusion system, it was judged appropriate to include these costs in the base cost estimate.

Thus, direct capital cost includes the costs of all materials, components, structures, and associated direct craft labor necessary to construct the reference facility at the plant site. Delivered costs for components, structures, and materials are used. Base indirect costs include site temporary construction facilities, payroll insurance and taxes, and other construction services, such as horne and field office expenses, field job supervision and engineering services. Specifically excluded from the base construction cost estimate are the items specified above, and items that are sensitive to the particular policies and preferences of the individual utility and to the specific plant site and prevailing economic factors being considered. These exclusions include the following list of items:

1. Owner's Costs - Consultants, Site Selection, etc.

2. Federal, State and Local Fees, Permits and Taxes

3. Interest on Capital Construction Funds

4. Price Escalation during Construction

5. Contingency Funds

6. Owner's Discretionary Items - switchyard and transmission costs, waste disposal costs, spare parts, and initial fuel supplies

With only a few exceptions, cost estimates provided in the NUWMAK report were taken directly as those for the reference design. The exceptions include a modification of average labor costs as previously discussed and the inclusion of a second 660 MWe unit on the same plant site. With regard to the second unit, only land costs (Account 20) and structures and improvements costs (Account 21) were assumed to be shared by the two units. Land costs are based on a 500 acre site valued at $\$ 4,480 /$ acre with half the total price assigned equally to each unit. Unit 2, Structures and Improvements costs, were estimated at $90 \%$ of the Unit 1 labor costs with savings attributable to reduced labor requirements for structures and improvements; and to learning as a result of construction of unit 1 . Table 7-5 summarizes the direct equipment, materials, and labor costs estimated for the 1320 MWe, two-unit reference fusion plant. 
Table 7-5. Estimated Direct Capital Costs for $1320 \mathrm{MWe}$ *

Fusion Reference System (January 1, 1978 Dollars)

\begin{tabular}{|c|c|c|c|c|}
\hline \multirow[b]{2}{*}{ Account } & \multirow[b]{2}{*}{ Description } & \multicolumn{3}{|c|}{ Dollars in Thousands } \\
\hline & & Unit 1 & Unit 2 & Total \\
\hline 20 & Land and Land Rights & 1,120 & 1,120 & 2,240 \\
\hline 21 & Structures and Improvements & 52,279 & 47,051 & 99,330 \\
\hline 22 & $\begin{array}{l}\text { Reactor Plant and Special } \\
\text { Materials }\end{array}$ & 457,277 & 457,277 & 914,554 \\
\hline 23 & 'L'urbine 'Lant Equipment & 14,433 & 14,433 & 148,866 \\
\hline 24 & Electric Plant Equipment & 24,676 & 24,676 & 49,352 \\
\hline 25 & Misc. Plant Equipment & 8,234 & 8,234 & 16,468 \\
\hline 26 & $\begin{array}{l}\text { Main Condencate Heat Rojection } \\
\text { System }\end{array}$ & 12,633 & 12,633 & 25,266 \\
\hline & Total Equipment \& Materials Costs & 630,652 & 625,424 & $1,256,076$ \\
\hline & Site Labor a \$13.04/man-hour & 142,136 & 135,029 & 277,165 \\
\hline & TOTAL DIRECT CAPITAL COSTS & 772,788 & 760,453 & $1,533,241$ \\
\hline
\end{tabular}

*Two-unit plant, each unit at 660 MWe

\subsection{INDIRECT COSTS}

Indirect costs for construction, home office, and field office engineering and services are estimated, based on the ratio of these cost accounts to the total direct costs for the EEDB boiling water reactor plant. In general, this results in a higher indirect cost estimate for the fusion plant than is estimated in the NUWMAK report. For a boiling water reactor, construction services (Account 91) are $16 \%$ of total direct costs, home office engineering and services (Account 92) are $19 \%$ of total direct costs, and field office engineering and services (Account 93) an additional 6\%. (The NUWMAK study assumes $15 \%, 15 \%$ and $5 \%$ respectively.) Table $7-6$ summarizes the estimated indirect costs which totai $\$ 628,628,000$ or $41 \%$ of the plant's direct costs. 
Table 7-6. Estimated Indirect Capital Costs for 1320 MNe Fusion Reactor Reference System (January 1, 1978 Dollars)

\begin{tabular}{|c|c|c|c|c|}
\hline \multirow[b]{2}{*}{ Account } & \multirow[b]{2}{*}{ Description } & \multicolumn{3}{|c|}{ Dollars in Thousands } \\
\hline & & Unit 1 & Unit 2 & Total \\
\hline 91 & Construction Services & 123,646 & 121,672 & 245,318 \\
\hline 92 & Home Office Engineering \& Services & 146,830 & 144,486 & 291,316 \\
\hline 93 & $\begin{array}{l}\text { Fleld Office Engineering and } \\
\text { Services }\end{array}$ & 46,367 & 45,627 & 91,994 \\
\hline & TOTAL INDIRECT COSTS & 316,843 & 311,785 & 628,628 \\
\hline
\end{tabular}

\subsection{OPERATIONS AND MAINTENANCE COSTS}

The NUWMAK study estimates annual operation and maintenance costs, exclisive of scheduled and unplanned replacements and fuel costs, to be $2 \%$ of the plant's total direct and indirect capital costs. Annual scheduled replacement of the first wall/blanket material was estimated at $\$ 4$ million/year for each unit. Additionally, the O\&M cost estimate includes an estimate of unscheduled interim replacements taken to be accrued in a sinking fund at $4 \%$ real interest per year. Total accrual after 30 years is assumed to be $30 \%$ of the plant's total direct and indirect costs exclusive of the reactor plant costs "for which scheduled replacements are accounted in the above cost. Table 7-7 sumnarizes the nonfuel $O \& M$ costs assuming a plant capacity factor of $70 \%$.

Fuel costs include the cost for replenishment of burned lithium and for the purchase of deuterium which is estimated to cost $\$ 1200 / \mathrm{kg}$. The NUWMAK study estimates these costs to be $\$ 449,000 /$ year per reactor at $81 \%$ capacity factor. This adjusts to $\$ 776,000 /$ year for two units operating at $70 \%$ capacity factor. 
Table 7-7. Annual Operation and Maintenance Costs--1320 MWe Reference Fusion Reactor System a 70\% Capacity Factor

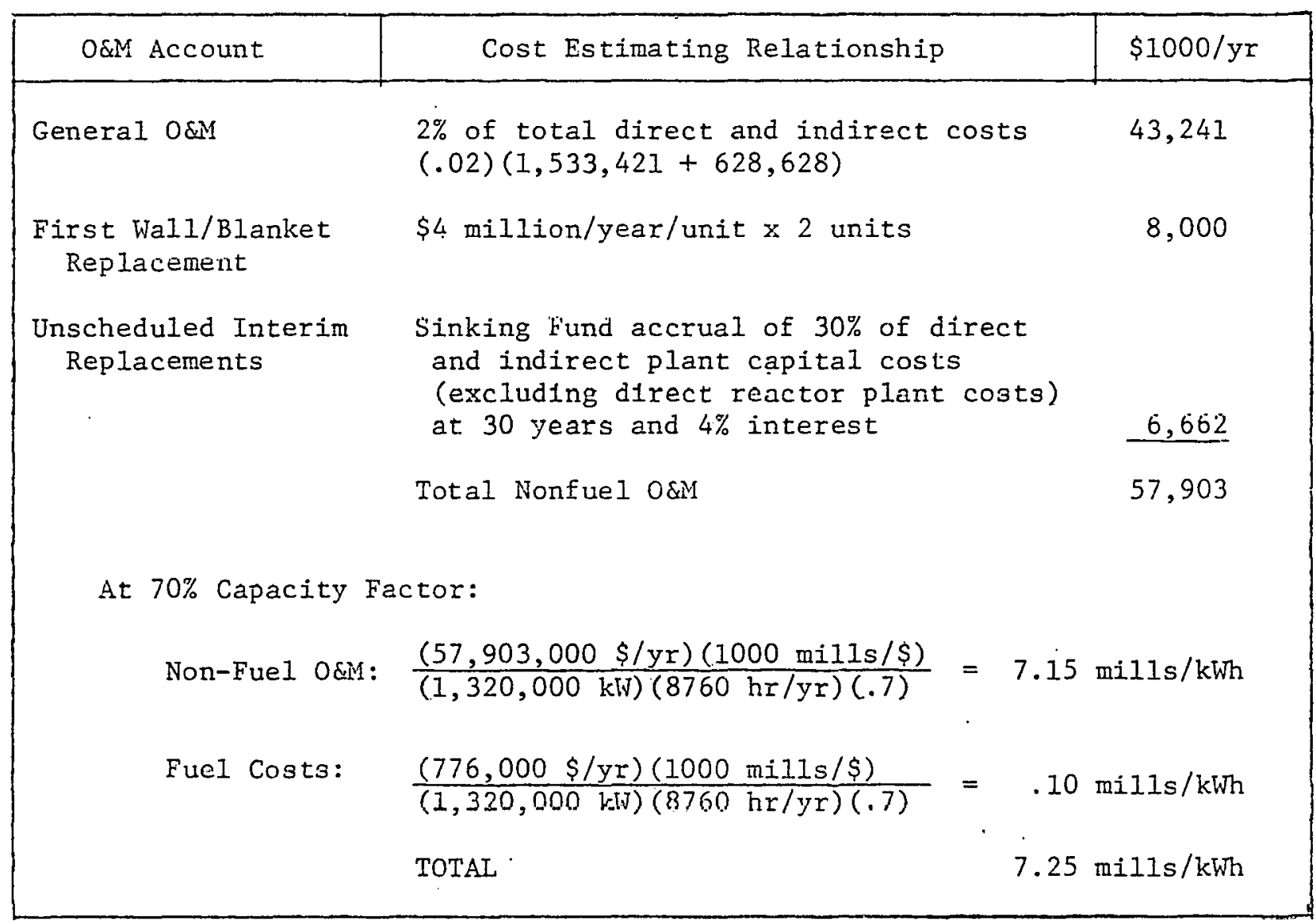


APPENDIX

ON CG/CC COST ESTIMATE 
Appendix

\section{COST ESTIMATING RELATIONSHIPS FOR REFERENCE COAL GASIFICATION COMBINED CYCLE SYSTEM}

This appendix details the cost estimating relationships for direct equipment costs and material costs for the reference 1250 MWe coal gasification facility. The series of tables (listed below) show the intermediate and final results of the procedure used to estimate the reference system costs (two 625 MVe units using Eastern Bituminous Coal) from costs presented in the Energy Conversion Alternatives Study (ECAS) for a single-unit 579 MWe facility using Illinois No. 6 coal. The facility complies to more restrictive environmental emission standards than is applicable to the reference design. All costs in this appendix are in 1975 dollars. The final cost estimate used in the body of the report is presented in January 1, 1978, dollars which have been converted from 1975 dollars by application of the corresponding GNP price deflator index ratio of 1.1365 .

The cost estimating procedure was as follows:

1. A detailed equipment and materials cost list for the original ECAS 579 NWe plant using Illinois No. 6 coal $(10,788 \mathrm{Btu} / \mathrm{lb} ., 3.9$ percent sulfur, 9.6 percent ash, and 59.6 percent carbon) was compiled under a code of accounts similar to that used in the Energy Economic Data Base. For the most part, except for the heat rejection system, this code of accounts is used in the ECAS study. (Another code of accounts used in the ECAS study for preparation of their equipment list: is shown under the equipment descriptions in the following tahles ton provide traceability to the original ECAS document.) Column A in the following tables shows these original costs separately for the plant's gasification module (GM) and balance of plant (BOP). The total cost is also shown.

2. Cost estimating exponents ( $\alpha$ ) were assigned to each of the major pieces of equipment based on an analysis of equipment lists and cost estimating exponents for conventional coal burning powerplants. Where no direct parallel of equipment type existed, basic design similarities were taken into cunsideration (e.g., tank, vessel, pump, turbine), before selecting an appropriate exponent. These exponents, shown in Column $B$ of each table, were subsequently used in the following equation to make adjustments in cost based on equipment sizing, capacity, or loading:

$$
\text { Cost of Component } B=\text { Cost of Component A } x\left(\frac{\text { Capacity of } B}{\text { Capacity of } A}\right)^{\alpha}
$$
where $a$ is the cost estimating exponent. 
3. Plant equipment loading or capacity ratios were then deternined for: (a) a 579 MWe facility using the Eastern Bituminous coal rather than the Illinois No. 6 coal $(11,026 \mathrm{Btu} / 1 \mathrm{~b}$., 3.2 percent sulfur, 10.29 percent ash, 61.49 percent carbon), and (b) conforming to less stringent environmental standards applicable to the reference system. Applicable ratios for the modified 579 MWe plant are shown in Column $C$ of the following tables. Column $D$ shows the costs for each piece of equipment, separately for the plant's gasification module and balance of plant. The costs are derived by application of loading ratios (C), cost estimating exponents (B) to the original ECAS cost estimates (A).

4. After correcting for coal characteristics and environmental standards, the system was sized to a net output of $625 \mathrm{MWe}$. In order to meet the ash throughput design limitation for each vessel and to ensure reliable operation, two additional gasification vessels were required. These additional vessels were not costed using the exponent technique. Rather, they were added at their given unit costs since no nudlfllaliun was assumed for the vessel itself. A 7.9 percent increase in component capabilities and loadings resulted in scaling up from 579 to 625 WWe. Costs for a single unit 625 MWe facility using the reference Eastern Bituminous coal are given in Column $E$ in the following tables. These values are derived from the Column $D$ values and the above cost estimating equation, a capacity ratio of 1.079 and cost estimating exponents shown in Column $B$.

5. Estimates were then made on a component-by-component basis of the incremental cost of adding a second 625 MWe unit on the same site. In some cases (e.g., coal handling equipment), that portion ot the equipment cost assignable directly to the individual unit's gasification module was not considered as shared equipment, while that equipment assignahte to the halanc.e of the plant. was assumed to be twice the Einglo unit capaoity and ehared by both units. The relationship indicated for estimating the incremental second unit cost for independent and shared facilities when identical capacities or loadings are required for each unit is as follows:

Independent (not shared) Equipment: $U_{2}=U_{1}$

Shared Equipment:

$$
\mathrm{U}_{2}=\mathrm{U}_{1}\left(2^{\alpha}-1\right)
$$

where $\mathrm{U}_{1}=$ Unit 1 cost

$\mathrm{U}_{2}=$ Unit 2 incremental cost

$\alpha=$ cost estimating exponent

Column $F$ indicates the shared or not shared assumption for each of the pieces of equipment, and Column $G$ shows the second unit incremental cost. 
6. All costs have been derived in 1975 dollars. The final table summarizes the direct capital costs for Unit 1 and Unit 2 of the reference facility for each major account. These values were derived by adding the component costs under each account for Unit 1 (Column $E$ ) and Unit 2 (Column $G$ ) and then escalating each of the account costs to January 1; 1978 dollars by multiplying by 1.1365 determined from the ratio of GNP price deflators. Consistent with the other technologies, land costs were estimated from a 500 acre site valued at $\$ 4,480$ per acre. Total site 1 and cost was assigned equally to each unit. 
Table A-1. Equipment and Materials List-Structures and Improvements - Account 21 (ECAS Ac:t 1.0) 1975 Dol_ars

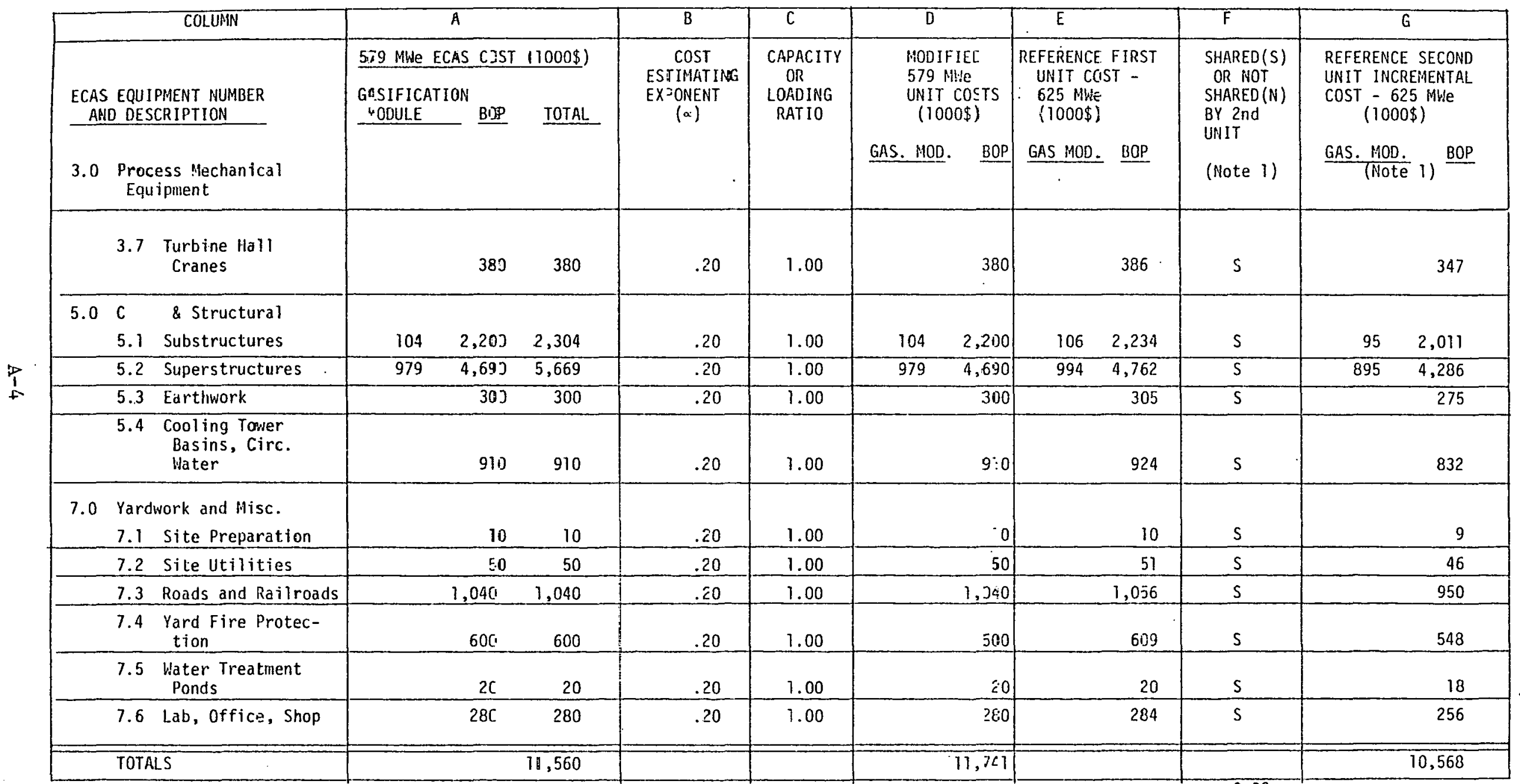

WOTE 1. A cost estivating exponent $(\alpha)$ of 0.92 used for all sinared structures and improvements cost of unit 2 component $=\left(2^{0.92}-1\right) \times$ cost of unit 1 component. 
Table A-2. Equipment and Materials L1st - Coal Handling

Gaslfication and Gas Cleanup - Account 22

(ECAS Acct. 2.0) - 1975 Dollars

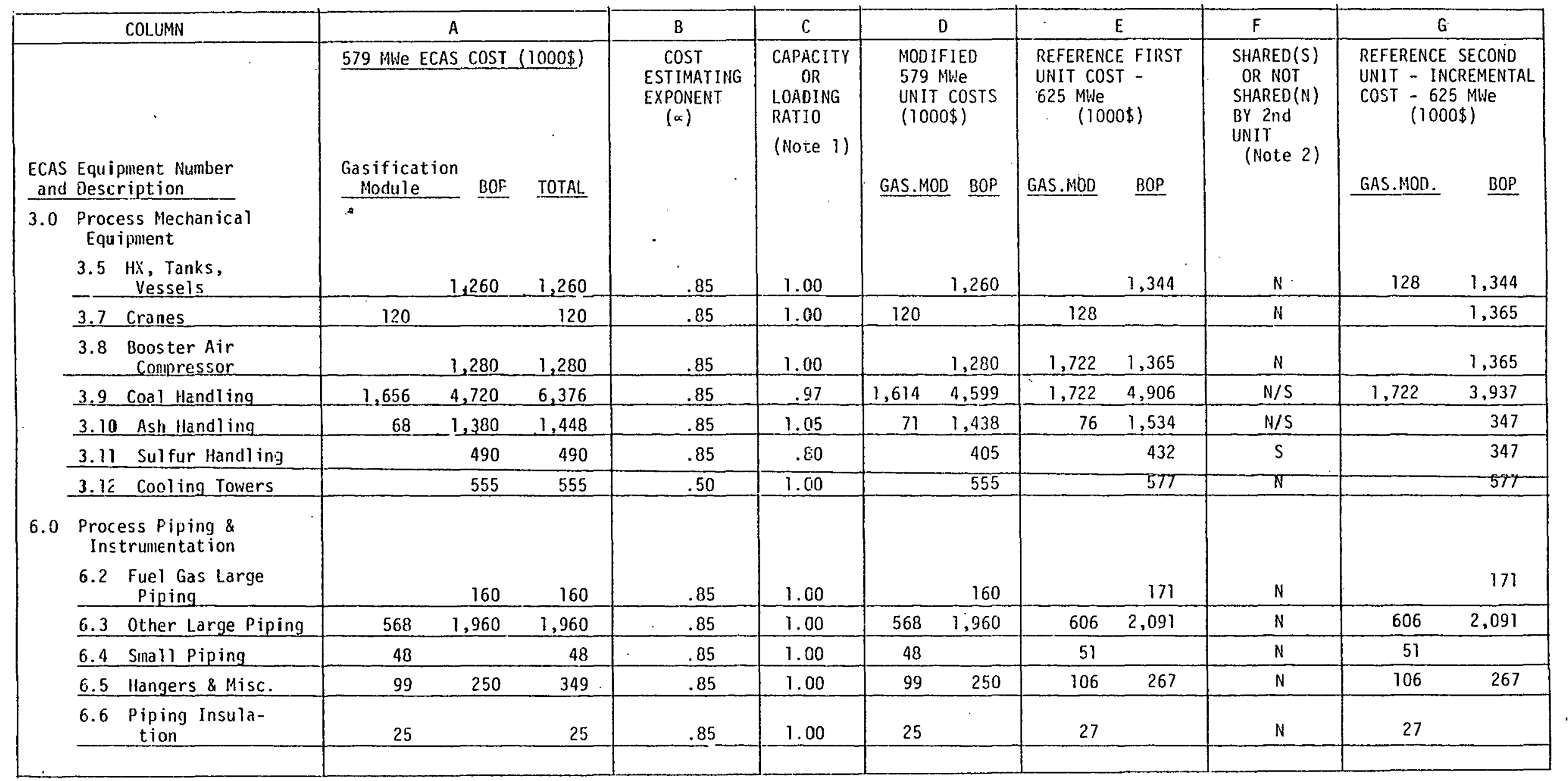


Table :-2. Equipment and Materials List - Cocl Handiling Gasification and Gas Cleanup - Account 22

(ECLS Acct. 2.0) $\div 1975$ Dollars (Continued)

\begin{tabular}{|c|c|c|c|c|c|c|c|c|c|}
\hline COLUMN & \multicolumn{2}{|l|}{ A } & \multirow{2}{*}{$\begin{array}{c}B \\
\text { COST } \\
\text { ESTIMATING } \\
\text { EXPONENT } \\
(x)\end{array}$} & \multirow{2}{*}{$\begin{array}{c}\text { C } \\
\text { CAPACITY } \\
\text { OR } \\
\text { LOADING } \\
\text { RATIO } \\
\text { (Note 1) }\end{array}$} & D & $\cdot \quad E$ & $F$ & \multicolumn{2}{|c|}{ G } \\
\hline $\begin{array}{l}\text { ECAS EQUIPMENT NUMBER } \\
\text { AND DESCRIPTION }\end{array}$ & $\begin{array}{l}\text { GASIFICATION } \\
\text { MODULE BCP }\end{array}$ & TOTAL & & & $\begin{array}{l}\text { MODIFIED } \\
579 \text { MHe } \\
\text { UNIT COS } \\
(1000 \$) \\
\text { GAS.H00. BCP }\end{array}$ & $\begin{array}{l}\text { REFEREHCE FIRST } \\
\text { UNIT COST - } \\
625 \text { MDE } \\
(1001 \$) \\
\text { GAS.MOD. BOP }\end{array}$ & $\begin{array}{l}\text { SHARED(S) } \\
\text { OR NOT } \\
\text { SHARED(N) } \\
\text { BY 2nd } \\
\text { UNIT } \\
\text { (Note 2) }\end{array}$ & $\begin{array}{r}\text { REFERENC } \\
\text { UNIT INC } \\
\text { COST }-6 \\
110 \\
\text { GAS.MOD. }\end{array}$ & $\begin{array}{l}\text { ECOND } \\
\text { ENTAL } \\
\text { MWV } \\
\text { BOP }\end{array}$ \\
\hline $\begin{array}{l}8.0 \text { Gas Cieanup } \\
\text { Systeln }\end{array}$ & & & & & & \multirow{2}{*}{$\begin{array}{l}\text { GAS.MOD. } \quad \underline{B O P} \\
529\end{array}$} & $\begin{array}{l}\text { UNIT } \\
\text { (Note 2) }\end{array}$ & \multirow{2}{*}{ GAS.MOD. } & BOP \\
\hline 8.1 Punips \& Drives & 600 & $\therefore 600$ & .85 & .80 & 456 & & $S$ & & 425 \\
\hline $\begin{array}{l}\text { B.2 Heaters and } \\
\text { Exchangers }\end{array}$ & 17.920 & 17,920 & .85 & .80 & $14,3 \div 4$ & 15,814 & $S$ & & 12,691 \\
\hline 8.3 Tanks and Vessels & 2.210 & 2,210 & .40 & .80 & $2, \sqrt{61}$ & 2,083 & $\mathrm{~S}$ & & 666 \\
\hline $\begin{array}{c}\text { 8.4 Anmonia Plant } \\
\text { Compressor }\end{array}$ & 420 & 420 & .85 & .80 & $3<7$ & 370 & $\mathrm{~S}$ & & 297 \\
\hline 8.5 Claus Plant & 8,400 & 8,400 & .60 & .80 & 7,347 & 7,690 & S & & 3,966 \\
\hline $\begin{array}{l}8.6 \text { Wellman-Lord } \\
\text { Plant }\end{array}$ & $\varepsilon .555$ & 8,555 & .60 & .80 & 7,783 & 7,332 & $\mathrm{~s}$ & & 4,039 \\
\hline $\begin{array}{l}\text { 9.0 Gasification Module } \\
9.1 \text { Gasifiers }\end{array}$ & 25,029 & 25,029 & 1.00 & $16 / 14$ & $25,02928,605$ & & N & 28,605 & \\
\hline 9.2 Wash Coolers & 357 & 357 & 1.00 & $16 / 14$ & 357 & 408 & N & 408 & \\
\hline 9.3 Coal Hoppers & 150 & 150 & 1.00 & $16 / 14$ & 150 & 771 & $\bar{N}$ & $T 71$ & \\
\hline TOTALS & & 78,275 & & & & 79,005 & & 65,414 & \\
\hline
\end{tabular}

Note 1: Ratio of 16/14 for gasifiers, ccolers and hoppers applied in .zolumns $E$ and $G$ only

Note 2: N/S indicates gasifier module nct shared, balance of plant shared. 
Table A-3. Equipment and Materials List-Prime (Gas Turbine) Cycle Eculpment - Account 23 (ECAS Acct. 3.0) - 1975 Dollars

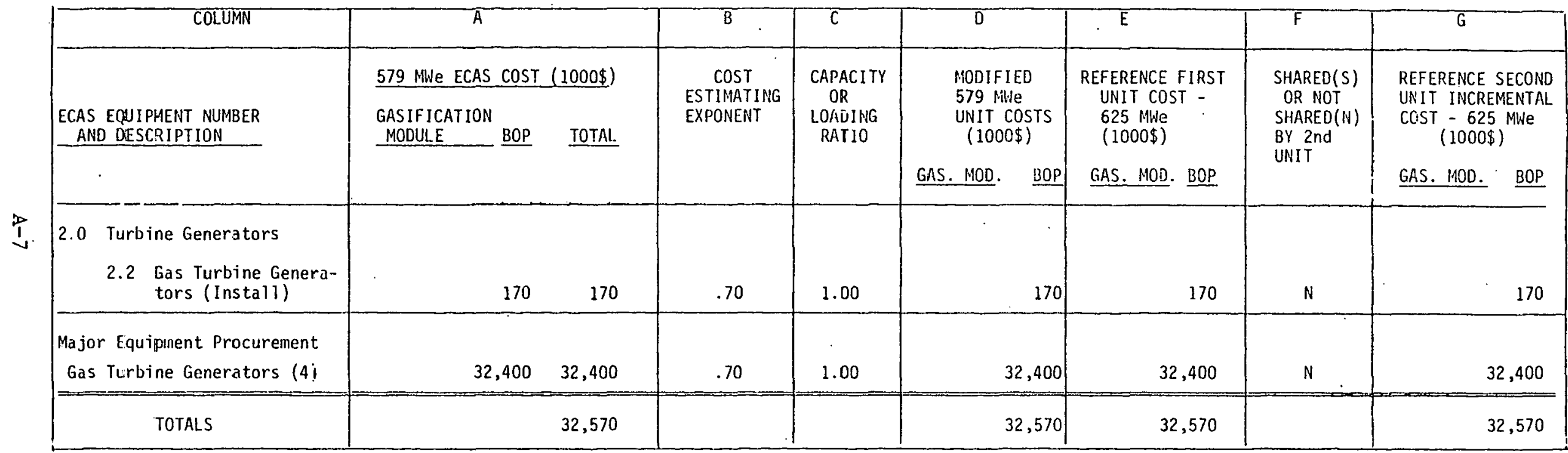

